MARilia Bense Othero

\title{
Atenção à saúde da pessoa com deficiência: necessidades sob a perspectiva dos sujeitos
}

Dissertação apresentada à Faculdade de Medicina da Universidade de São Paulo para obtenção do título de Mestre em Ciências.

Área de concentração: Medicina Preventiva Orientador: Prof. Dr. José Ricardo de Carvalho Mesquita Ayres

São Paulo

2010 
Dados Internacionais de Catalogação na Publicação (CIP)

Preparada pela Biblioteca da Faculdade de Medicina da Universidade de São Paulo

(C)reprodução autorizada pelo autor

Othero, Marília Bense

Atenção à saúde da pessoa com deficiência: necessidades sob a perspectiva dos sujeitos / Marília Bense Othero. -- São Paulo, 2010.

Dissertação(mestrado)--Faculdade de Medicina da Universidade de São Paulo. Programa de Medicina Preventiva.

Orientador: José Ricardo de Carvalho Mesquita Ayres.

Descritores: 1.Pessoas com deficiência 2.Determinação de necessidades de cuidados de saúde 3.Assistência integral à saúde

USP/FM/DBD-431/10 
Dedico este trabalho àqueles que participaram e muito contribuíram: Sr.Jair, Ricardo, Cristina, Ângela, Fátima e Rubens... 


\section{Agradecimentos}

Ao Vinicius, sempre...

Aos meus pais e minha família pelo apoio e incentivo.

Ao professor e orientador deste trabalho José Ricardo Ayres, por compartilhar comigo esta jornada.

Às professoras que participaram da banca de qualificação: Fátima Oliver, Márcia Thereza Couto Falcão, Ana Silvia Withaker Dalmaso.

Aos colegas que contribuíram na indicação de sujeitos para a pesquisa: Marta Aoki, Liliana Lourenço Jorge, Henrique Afonseca Parsons, José Carlos Fagundes Martins, Cássia Sígolo, Prof. Maria Inês Vieira Couto, Dr. Sérgio Garbi.

A todos que de alguma forma contribuíram para que este trabalho se concretizasse. 
Esta dissertação está de acordo com as seguintes normas, em vigor no momento desta publicação:

Referências: adaptado de International Committee of Medical Journals Editors (Vancouver)

Universidade de São Paulo. Faculdade de Medicina. Serviço de Biblioteca e Documentação. Guia de apresentação de dissertações, teses e monografias. Elaborado por Anneliese Carneiro da Cunha, Maria Julia de A. L. Freddi, Maria F. Crestana, Marinalva de Souza Aragão, Suely Campos Cardoso, Valéria Vilhena. 2a ed. São Paulo: Serviço de Biblioteca e Documentação, 2005.

Abreviaturas dos títulos dos periódicos de acordo com List of Journals Indexed in Index Medicus. 


\section{Sumário}

Lista de siglas

Resumo

Summary

I. Apresentação

II. Apontamentos teórico-conceituais

2.1 - A pessoa com deficiência e a saúde: contextualizando a pesquisa

2.2 - Paradigmas e conceitos em saúde da pessoa com deficiência

2.3 - Saúde da pessoa com deficiência no Brasil

2.3.1 - Legislação em saúde da pessoa com deficiência

2.4 - Necessidades de saúde

2.5 - Necessidades de saúde das pessoas com deficiência: uma leitura possível

2.6 - Diálogos com o campo da Saúde Coletiva: cuidado e integralidade

III. Objetivo

IV. Metodologia

4.1 - Organização do estudo

4.2 - O campo da pesquisa

4.3 - As histórias

V. A partir dos relatos...

5.1 - A vivência da deficiência

5.1 .1 - Nas relações...

5.1 .2 - Explicações e construções de sentido

5.3 - Acesso e direitos

\subsection{1 - Acesso e saúde}

5.4 - Percursos e sentidos das intervenções em saúde

5.5 - Ações e estratégias

5.6 - Necessidades de saúde das pessoas com deficiência 
VII. Anexos

A. Parecer do comitê de ética em pesquisa

B. Roteiro de entrevistas

C. Roteiro do diário de campo

D. Modelo do termo de consentimento livre e esclarecido

E. Diário de campo

F. As histórias

210

VIII.Referências Bibliográficas 


\section{Lista de Siglas}

AIS

ATENDE

CID

CIDID

CIF

CORDE

LILACS

NASF

OIT

OMS

ONU

OPAS

RBC

SUDS

SUS

UBS

UNESCO

UNICEF

USP
Ações Integradas de Saúde

Serviço de Atendimento Especial

Classificação Internacional das Doenças

Classificação Internacional das Deficiências, Incapacidades e Desvantagens

Classificação Internacional de Funcionalidade

Coordenadoria Nacional para Integração da Pessoa

Portadora de Deficiência

Literatura Latino-Americana e do Caribe em Ciências da Saúde

Núcleos de Apoio à Saúde da Família

Organização Internacional do Trabalho

Organização Mundial da Saúde

Organização das Nações Unidas

Organização Panamericana da Saúde

Reabilitação Baseada na Comunidade

Sistema Único Descentralizado de Saúde

Sistema Único de Saúde

Unidade Básica de Saúde

Organização das Nações Unidas para a Educação, a Ciência e a Cultura

Fundo das Nações Unidas para a Infância

Universidade de São Paulo 
Othero MB. Atenção à saúde da pessoa com deficiência: necessidades sob a perspectiva dos sujeitos [dissertação]. São Paulo: Faculdade de Medicina, Universidade de São Paulo; 2010. 320p.

O panorama de desassistência no âmbito da saúde da pessoa com deficiência se mantém, mesmo com alguns avanços trazidos pelo SUS. O conceito de necessidade de saúde como norteador das práticas pode possibilitar a abertura de novos espaços de reflexão e ação para esta população, sendo fundamental a inclusão das próprias pessoas nesta discussão. O objetivo do trabalho aqui descrito é identificar quais são as demandas e necessidades de saúde das pessoas com deficiência, a partir da ótica destes sujeitos. Foi realizado um estudo de metodologia qualitativa, sendo a história de vida a técnica de produção dos dados adotada; foram incluídos na pesquisa pessoas com deficiência física, auditiva e visual, com deficiência congênita e adquirida, e com histórico de atendimento no SUS. Foram realizadas entrevistas em profundidade, baseadas em um roteiro prévio, sendo gravadas e posteriormente transcritas; também foi feito um diário de campo. A análise do material foi feita em três níveis: palavras-chave, temas emergentes e tendências gerais. Produziu-se um texto analítico com os temas emergentes das narrativas, bem como um quadro sintético, elencando os núcleos temáticos sobre necessidades de pessoas com deficiência. Das narrativas, cinco temas principais estiveram presentes: a vivência da deficiência; independência, autonomia e apoio; acesso e direitos; sentidos das intervenções; ações e estratégias. Em relação às necessidades e a atenção em saúde, onze eixos temáticos foram elencados: Acesso; Apoio psicossocial; Aspectos gerais de saúde (para além da deficiência); Autonomia e independência; Dispensação de equipamentos e dispositivos de tecnologia assistiva; Informação / orientação; Prevenção / diagnóstico precoces; Reconhecimento e garantia de direitos; (Re)Encontro com atividades significativas; Validação e ajuda na construção de estratégias próprias de enfrentamento; Vínculo com profissional de saúde. Pôde-se concluir que as necessidades identificadas pelas pessoas com deficiência incluem aspectos específicos da assistência em saúde, mas englobam outras dimensões como o acesso, os direitos, o trabalho, o lazer, indicando a importância de ações integrais e intersetoriais. Ressalta-se também as singularidades que a vivência da deficiência impõe a cada sujeito, bem como os sentidos que cada um encontra em sua história de vida.

Descritores: 1. Pessoas com deficiência 2. Determinação de necessidades de cuidados de saúde 3 . Assistência Integral à saúde 
Othero MB. Health care of people with disabilities: needs in the perspective of the subjetc [dissertation]. São Paulo: Faculdade de Medicina, Universidade de São Paulo; 2010. 320p.

The lack of assistance panorama in the health of the disabled person still exists, despite some advances brought by SUS. The concept of health needs as a guide for the practices may allow new spaces for reflection and action for this population, and the inclusion of disabled people in this discussion is of extreme importance. The aim of the work described here is to identify demands and health needs of people with disabilities, by the subjects' perspective. The study was conducted by the use of a qualitative methodology, through the life history method; and people with physical, hearing and visual disabilities, congenital or acquired, with history of assistance by SUS were included. Interviews were conducted based on a previous script, being recorded and later transcribed; and also a field diary was made. The data analysis was done on three levels as follows: keywords, emerging issues and trends. An analytical text with the emerging themes of the narratives, and a summary table have been produced listing the central themes on the people with disabilities needs. Using narratives, five major themes emerged: the experience of disability; independence, autonomy and support; access and rights; meaning of the interventions; actions and strategies. Eleven themes were listed when considering needs and health care: access; psychosocial support; general health issues; autonomy and independence; dispensing of equipment and assistive technology devices; information/guidance; prevention/early diagnosis; recognition and guarantee of rights; recovery of meaningful activities; validation and help in building their own strategies for coping; bonding with health professional. It was concluded that the needs identified by people with disabilities include specific aspects of health care, but also include other dimensions such as access, rights, work, leisure indicating the importance of integrated and intersectoral actions. Singularities that the experience of disability brings to each person are also emphasized, as well as the meanings that each one finds in its life history.

Descriptors: 1. Disabled persons 2. Needs Assessment 3. Comprehensive Health Care 


\section{Apresentação}

Sou terapeuta ocupacional, graduada pela Universidade de São Paulo (USP) em 2004. Fiz aprimoramento/especialização em Saúde Coletiva no ano de 2005, pelo Departamento de Medicina Preventiva da Faculdade de Medicina, USP. Atualmente trabalho como coordenadora da equipe de Saúde Mental de um grupo de empresas, chamado "Grupo MAIS - Modelo de Atenção Integral à Saúde", composto por um hospital de Cuidados Paliativos, e duas empresas de assistência domiciliar, todos especializados no atendimento a idosos e pacientes crônicos de alta dependência. E assim, no cotidiano do trabalho, estou envolvida na assistência a pacientes com deficiências graves: adultos e idosos com seqüelas importantes pós Acidente Vascular Encefálico, Traumatismo CrânioEncefálico e doenças crônico-degenerativas (Doença de Alzheimer, Doença de Parkinson, Esclerose Lateral Amiotrófica, Neoplasias, entre outras).

Além da vivência de trabalho, meu interesse pelo tema da assistência em saúde a pessoas com deficiência já vem desde a graduação, com leituras, estudos e práticas em estágios; no aprimoramento, estive envolvida com pesquisa neste tema e também com assistência a pessoas com deficiência em atenção primária. Em todos estes campos, venho observando que muitas demandas e necessidades das pessoas e de suas famílias não são contempladas pelo sistema de saúde, com pouco espaço para acolhimento e escuta.

Esta observação prática, junto com o interesse em desenvolver-me na área acadêmica - vislumbrando a área de docência para meu futuro profissional - me levaram a optar pelo ingresso em um programa de pós-graduação, no Departamento de Medicina Preventiva, no qual já havia desenvolvido atividades anteriormente, sob orientação do Prof. José Ricardo C. M. Ayres. 
Os referenciais da Saúde Coletiva embasam minha prática profissional, e acredito poderem contribuir para a discussão da assistência às pessoas com deficiência. Ainda que a área da saúde venha desenvolvendo referenciais pautados no cuidado às populações, penso que, muitas vezes, as práticas são embasadas em referenciais que não parecem incluir o saber, o desejo e a necessidade daquele que é atendido, potencializando-se em populações mais vulneráveis, como o caso das pessoas com deficiência.

A partir disso, coloquei-me as seguintes questões inicialmente:

- Quais necessidades de saúde são identificadas pelas próprias pessoas com deficiência?

- Como os serviços de saúde respondem a elas, na perspectiva destes usuários?

E foi a partir delas que, em 2008, elaborei o projeto desta pesquisa intitulado "Atenção à saúde da pessoa com deficiência - Necessidades sob a perspectiva dos sujeitos", propondo-se a estudar estes aspectos na área da atenção à saúde desta população, a partir de histórias de vida das próprias pessoas com deficiência, e desde então venho nela trabalhando.

Ao longo do campo desta pesquisa, além das leituras e reflexões que me acompanharam durante todo o processo, o projeto sofreu alterações e os objetivos foram se refinando. Os objetivos, o roteiro de entrevistas e toda a reflexão e análise, antes mais focados na assistência em saúde, acabaram voltando-se para a vida com deficiência (e todas as implicações nela contidas, inclusive a saúde), ampliando-se o conceito de necessidade adotado inicialmente.

Pelo volume de material produzido, da proposição no projeto inicial de doze sujeitos a serem entrevistados em profundidade, finalizamos o trabalho em seis 
sujeitos. Ainda assim, não foi fácil encontrar os seis sujeitos, especialmente as pessoas com deficiência auditiva e visual congênitas.

A qualificação do trabalho, em junho de 2009 , foi feita propositalmente no início do trabalho, com apenas uma entrevista finalizada e analisada, possibilitando a abertura de espaços importantes de reflexão e discussão ao longo do restante do trabalho, novamente em um movimento de ampliação.

No material aqui apresentado, está o estudo finalizado. A seguir, estão apresentadas as justificativas deste estudo, os referenciais teóricos adotados e o objetivo (capítulos II e III). No capítulo IV, é descrita o metodologia utilizada, em seus quadros conceituais e operacionais. Posteriormente, são apresentadas a análise dos resultados e as considerações finais (capítulos V e VI). Como anexos constam os roteiros do diário de campo e das entrevistas, o diário de campo propriamente dito, as seis histórias de vida dos sujeitos entrevistados, o termo de consentimento livre e esclarecido, e o parecer da comissão de ética em pesquisa da faculdade. Ao final, estão as referências bibliográficas. 


\section{II.Apontamentos teórico-conceituais}

\section{1 - A pessoa com deficiência e a saúde: contextualizando a pesquisa}

Segundo dados publicados por Rocha ${ }^{1}$, em todo o mundo, as pessoas com deficiência são as mais pobres entre os pobres, têm acesso negado sob diferentes aspectos (espaços urbanos, edifícios, informação, oportunidades), são impedidas de fazer escolhas, até mesmo de ter controle sobre a própria vida. Almeida et al. ${ }^{2}$ mencionam que a Organização Mundial de Saúde (OMS) prevê que $10 \%$ da população mundial apresente algum tipo de deficiência, sendo que cerca de $1,5 \%$ da população são pessoas que se beneficiariam de serviços de reabilitação; porém, estima-se que as instituições e serviços conseguem prover algum tipo de atendimento a apenas $2 \%$ deste contingente. Ressalta-se que, de acordo com Bernardes et al. ${ }^{3}, 80 \%$ das pessoas com deficiência vivem em países em desenvolvimento.

Rocha $^{1}$ apresenta os seguintes dados: a incidência de pessoas com deficiência é de 3 milhões a cada ano, e um terço destes casos poderiam ter sido evitados com estratégias de prevenção da saúde; reitera-se o mundo contemporâneo como "produtor" de deficiências, com o envelhecimento da população, o aumento das doenças crônico-degenerativas, os acidentes de trânsito, os acidentes de trabalho, a violência das grandes cidades, entre outros fatores.

Dentre as causas das deficiências destacam-se: transtornos congênitos e perinatais $(16,6 \%)$, que podem ser conseqüência da falta de assistência às mulheres na gravidez; as doenças transmissíveis (16,8\%); as doenças crônicodegenerativas (21\%); as alterações psicológicas (6,6\%); o alcoolismo e o abuso 
de drogas $(10 \%)$; as causas externas $(18 \%)$; a desnutrição e outros fatores associados à miséria $(11 \%)^{4}$.

Segundo Censo Demográfico de $2000^{5}$, o número de pessoas com deficiência no Brasil é de 24,5 milhões de pessoas, correspondendo a aproximadamente $14,5 \%$ da população. Destas, tem-se: $48,1 \%$ com deficiência visual; 22,9\% com deficiência motora; $16,7 \%$ com deficiência auditiva; 8,3\% com deficiência mental e 4,1\% com deficiência física*. Para a cidade de São Paulo, segundo estimativa da Secretaria Municipal da Pessoa com Deficiência e Mobilidade Reduzida ${ }^{6}$, há uma taxa de $14,57 \%$ de pessoas com deficiência (para uma população de cerca de 10,5 milhões de habitantes), com uma distribuição semelhante entre os tipos de deficiência, descritos anteriormente.

Há predominância de deficiência entre as mulheres, sendo que no sexo feminino prevalecem as deficiências motoras e visuais, compatível com a composição por sexo da população idosa. No sexo masculino, prevalecem as deficiências mentais, físicas e auditivas, compatível com o tipo de atividades laborais exercidas e ao grau de exposição aos acidentes e à violência? .

Além dos dados epidemiológicos que possibilitam verificar a abrangência da deficiência na população brasileira, é preciso considerar que a deficiência - e mais que isso, a vivência da incapacidade - perpassa a todos os sujeitos em

* O Censo 2000 baseou-se na seguinte classificação ${ }^{5}$ :

- Deficiência física: tem alguma das seguintes deficiências: paralisia permanente total; paralisia permanente das pernas; paralisia permanente de um dos lados do corpo; falta de perna, braço, mão, pé ou dedo polegar;

- Deficiência motora: como avalia sua capacidade de caminhar/subir escadas - incapaz, grande ou alguma dificuldade permanente;

- Deficiência auditiva: como avalia sua capacidade de ouvir (se utiliza aparelho auditivo faça sua avaliação quando o estiver usando) - incapaz, grande ou alguma dificuldade permanente;

- Deficiência visual: como avalia sua capacidade de enxergar (se utiliza óculos ou lentes de contato, faça sua avaliação quando os estiver usando) - incapaz, grande ou alguma dificuldade permanente;

- Deficiência mental: tem alguma deficiência mental permanente que limite as atividades habituais (como trabalhar, ir à escola, brincar, etc.).

Há uma classificação das deficiências mais recente, apresentada no decreto n 5.296/04, que será utilizada como base para este trabalho, e será descrita posteriormente, no capítulo $\mathrm{V}$, sobre a metodologia utilizada. 
algum momento da vida: seja pela afeç̧ão por uma doença crônica incapacitante, seja pelo suporte ao sujeito nesta condição, e, então, torna-se muito relevante ouvir estes sujeitos, seus valores, práticas e considerações acerca de suas necessidades. Bernardes et al. $^{3}$ fazem uma consideração bastante importante sobre o contingente das pessoas com deficiência:

É imprescindível salientar que as pessoas com deficiência constituem um grupo heterogêneo que reúne, em uma mesma categoria, indivíduos com vários tipos de deficiência física, sensorial, intelectual e mental. Por conseguinte, as ações em saúde voltadas para este segmento têm que considerar um mosaico de diferentes necessidades (p.32).

Ainda segundo os autores, a agenda governamental brasileira não tem contemplado suficientemente as questões relativas à pessoa com deficiência, em seus diferentes âmbitos (saúde, educação, trabalho, cultura, lazer, etc.).

Na Política Nacional de Saúde da Pessoa com Deficiência ${ }^{8}$, é discutida a importância de um adequado sistema de informações sobre incidência e prevalência de deficiências no Brasil, visto que "será essencial para o adequado equacionamento das questões relativas à saúde da pessoa com deficiência" (p.24). Porém, não é abordada a opinião dos grupos de pessoas com deficiência - o que os sujeitos entendem por suas necessidades poderia contribuir para o seu adequado equacionamento.

Segundo Pereira ${ }^{9}$, os discursos e práticas construídos em torno da deficiência são externos a ela, funcionando como um amontoado de dados, em que informações procedentes e válidas misturam-se a dados distorcidos pelos valores, medos, culpas e preconceitos acerca da deficiência, em um movimento de distinção "nós", os sem deficiência, e "eles", os com deficiência. Assim, nesta pesquisa, compartilha-se do posicionamento de Caiado ${ }^{10}$, sobre a importância de considerar este sujeito nas práticas, estudos e proposições: 
Alguém, geralmente, fala e decide por eles. Em nome deles, muitas vezes, definem-se políticas, abrem-se serviços, organizam-se cursos e congressos. Nesse sentido, aqui se busca conhecer o que eles têm a contar sobre suas vidas, suas experiências, seus anseios... (p.44).

Diante destas considerações, constata-se que esta é uma temática de grande relevância para a Saúde Pública, ainda pouco desenvolvida. Com isso, a pesquisa pode colaborar no sentido de suscitar a discussão e a reflexão sobre o tema, permitindo aos profissionais leitores repensarem suas práticas, contribuindo para transformações e inovações no campo. Outro aspecto relevante é a pouca bibliografia disponível na área, tendo o estudo sua contribuição no campo científico.

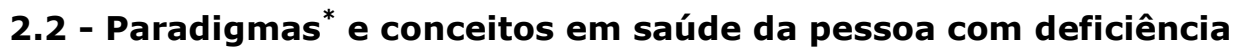

Na Antiguidade, prevalecia a concepção das deficiências como um problema ligado ao âmbito religioso, como uma manifestação do mal e do pecado. A deformidade era vista como um afastamento de Deus, a expressão e a conseqüência de uma desordem (algo mau, feio, doente e nunca desejado por Deus); restava aceitação resignada, a exclusão da vida social e a eliminação deste sujeito do contexto social ${ }^{11}$.

Até o final do século XIX, permanece a compreensão da deficiência como uma produção mítica, religiosa ou de ameaça social. As práticas voltadas às pessoas com deficiência baseavam-se na segregação, com o isolamento daqueles que eram considerados perigosos à sociedade; as instituições para esta

\footnotetext{
* Termo aqui utilizado de maneira ampla, como um referencial de compreensão sobre determinada questão (no caso a deficiência), que inclui conceitos, crenças e valores. Ainda que não especificado conceitualmente, é o termo utilizado pelos autores do campo da reabilitação citados, e por isso, optou-se em manter este conceito no presente trabalho.
} 
finalidade eram gerenciadas pela Igreja Católica, tendo a caridade e a purificação como objetivo ${ }^{1}$. Há uma compreensão metafísica da enfermidade neste período, vigorando um paradigma "biológico-religioso"12.

Palacios e Romañach ${ }^{13}$ nomeiam este paradigma de "modelo da prescindência", reforçando que nesta concepção, compreende-se as pessoas com deficiência como "não necessárias", pois não contribuem para a comunidade, trazem mensagens diabólicas, representam um "enojo" dos deuses, enfim uma vida que não merece ser vivida. Os autores entendem ainda que este modelo tem dois submodelos, dele derivados: submodelo da eugenia e segregação e submodelo da marginalização.

É no século XIX que a deficiência passa a ser compreendida enquanto categoria científica, com o surgimento do conceito de patológico na Medicina e nas Ciências Sociais. O corpo passa a ser objeto de estudo e intervenção da ciência e o olhar volta-se cada vez mais para as doenças e o controle de suas manifestações; o hospital passa a ser espaço da ação médica. Também surgem as noções de disciplina e controle ${ }^{1}$.

Faz-se necessário ressaltar, porém, que as concepções e representações míticas e ameaçadoras das pessoas com deficiência não desaparecem, permeando toda a relação dela com o mundo, até os dias atuais.

Segundo Ghirardi ${ }^{12}$, é também no século XIX que a idéia de enfermidade passa a ser relacionada à noção de tratamento; com o advento das práticas pedagógicas, a enfermidade também vai se tornando "educável" e os aspectos sociais são vistos como passíveis de controle. De acordo com Palacios e Romañach $^{13}$, as causas das deficiências vão sendo compreendidas como científicas, e as pessoas com deficiência como seres que precisam ser reabilitados, em um objetivo de normalização, ainda que isto implique em desaparecer ou ocultar a diversidade do sujeito. O ser humano passa a ser 
definido por papéis, que devem ser cumpridos para a efetivação do contrato social.

O conceito de reabilitação é cunhado neste período (em 1844, por Franz Joseph Ritter von Buss) ${ }^{1}$ : "Tão logo o enfermo curado, deve ser reabilitado totalmente, ajudando-o a ocupar o posto do qual havia descido, e é necessário que adquira novamente a sensação de sua dignidade pessoal e, com ela, uma nova vida" (p.44).

As primeiras instituições de reabilitação surgem neste momento, com o objetivo claro de preparar o deficiente para a integração social, classificando-o a partir de uma patologia ${ }^{1}$. Durante todo o século XIX, estas instituições se disseminaram como proposta de assistência às pessoas com deficiência; porém, a Rocha $^{1}$ ressalta que 0 objetivo de segregação $e$ isolamento acabou prevalecendo ao objetivo de retorno ao convívio social.

No século $\mathrm{XX}$, e com o fortalecimento do capitalismo, há uma associação da idéia de reabilitação com a idéia de capacitação para a produção, bem como uma ampliação dos conceitos médicos e biológicos sobre a deficiência. Reabilitação passa a ser quase um sinônimo de recuperação das funções motoras, para o restabelecimento do padrão corporal mais próximo do normal; havendo esta recuperação, sendo inerente a inserção social do sujeito portador de deficiência ${ }^{1}$. Este modelo se consolida nas décadas de 1940 e 1950 do século XX, com o desenvolvimento dos grandes centros de reabilitação, nas principais áreas urbanas.

Durante todo este período, vai se configurando o chamado "paradigma médico" de compreensão e ação sobre a deficiência ${ }^{12}$. De acordo com Guirardi ${ }^{12}$, Em tal modelo de entendimento, há uma cisão entre corpo e psique, entre corpo e história, entre o âmbito individual e o social, sendo valorizados apenas os aspectos individuais e orgânicos; o técnico é o detentor do saber científico e o 
usuário uma pessoa desprovida de subjetividade. Palacios e Romañach ${ }^{13}$ nomeiam este modelo de "reabilitador", e pontuam que o êxito da intervenção está na quantidade de destrezas e habilidades adquiridas; para estes autores, uma conseqüência deste modelo é a taxonomia das deficiências baseada no referencial médico.

Os conceitos de reabilitação entre as décadas de 50 e 80 , como trazido por Rocha ${ }^{1}$, também estão intimamente relacionados a este paradigma. Na década de 1950 tem-se: "[Reabilitação é] um conjunto de medidas físicas, mentais, sociais, profissionais e econômicas com a finalidade específica de fazer com que um indivíduo deficitário, usando toda a sua capacidade restante, esteja apto a, por si só, prover sua própria subsistência" (p.44). A autora ressalta a idéia de tornar o indivíduo produtor e o foco da intervenção no campo biológico / individual.

Já na década de 1980, apesar de algumas modificações textuais e a incorporação do conceito de desvantagem (como um aspecto social da deficiência), a definição de reabilitação da OMS mantém o foco sobre o corpo do indivíduo: "...[A reabilitação] Compreende todas as medidas destinadas a reduzir os efeitos das afecções que produzem incapacidade ou desvantagem, e a permitir ao incapacitado ou deficiente sua integração social" (p.45) ${ }^{1}$.

Nesta lógica, está no organismo individual a causa e o fim da exclusão, bem como a responsabilidade pela sua posição de excluído e de sua (re)inserção social; as práticas de reabilitação teriam uma função de manutenção da norma, de um padrão físico e estético dominante ${ }^{12}$.

Na prática da assistência às pessoas com deficiência, porém, o ciclo não se completa; ou seja, na realidade concreta da vida das pessoas estar reabilitado fisicamente não implica necessariamente em independência e autonomia no cotidiano familiar e sociocultural. Além disso, em muitos casos, o ganho e/ou o 
retorno de funções motoras tem limitações importantes, o que ocasionaria neste paradigma - nunca estar apto a realizar suas atividades e se relacionar em seu contexto.

Segundo Rocha ${ }^{1}$, foi da década de 1960 que surgiram os primeiros questionamentos acerca do paradigma médico de reabilitação, uma vez que muitos países (especialmente aqueles em desenvolvimento) não tinham condições de implantá-lo. A partir da década de 1970, as organizações internacionais (como OIT, ONU, OMS, UNESCO, UNICEF) incentivaram a mudança do modelo hegemônico, uma vez que foram detectadas dificuldades no acesso da população a estes serviços tradicionais.

Começou a haver, neste momento, propostas de inclusão de reabilitação na atenção primária, com incentivo à participação da comunidade, suprindo necessidades básicas e diminuindo-se as diferenças de oportunidades. Como chamado por Ghirardi ${ }^{12}$, a referencia para compreensão e ação sobre a questão da deficiência torna-se o "paradigma social", que busca envolver questões não somente individuais/orgânicas e as limitações advindas da deficiência, mas também o contexto, a história do sujeito, sua subjetividade. Parte-se do pressuposto que as necessidades das pessoas com deficiência estão atreladas ao contexto social em que estão imersas.

A autora pontua que neste modelo considera-se que pessoa tem peculiaridades subjetivas que devem ser contempladas no processo de reabilitação; deve-se lidar com o sujeito e suas necessidades em seu cotidiano, e usuário e técnico são co-partícipes do processo de atenção à saúde. A reabilitação, portanto, implica necessariamente em intervenções no âmbito 
social, para maior permeabilidade e continência às diferenças*. Ainda segundo Ghirardi ${ }^{12}$ :

\begin{abstract}
Essas novas práticas buscam o resgate da condição de sujeito social das pessoas com deficiência através da construção de sentidos de vida que resgatem as possibilidades afetivas e de relacionamento dessas pessoas, o que só pode ocorrer dentro de seu ambiente de vida cotidiano, co-envolvendo a própria comunidade e levando em consideração os conflitos que emergem das interações sociais com a diversidade (p.29).
\end{abstract}

Foi também no final da década de 1970 que a OMS criou uma classificação para as afeç̧ões crônicas e irreversíveis; até então, na Classificação Internacional das Doenças (CID-8), apenas as manifestações agudas eram consideradas. Com a criação da Classificação Internacional das Deficiências, Incapacidades e Desvantagens: Um Manual de Classificação das Conseqüências das Doenças (CIDID), traduzida para a língua portuguesa apenas em 1989, foram apresentados novos conceitos para a compreensão da questão, possibilitando discussões mais complexas e ampliação dos níveis de ação.

Amiralian et al. ${ }^{14}$ explicam os conceitos da CIDID:

- Deficiência: é a perda ou anormalidade de estrutura orgânica ou função (psicológica, fisiológica ou anatômica), seja ela temporária ou permanente. O conceito de deficiência representa a exteriorização de um estado patológico, refletindo um distúrbio orgânico;

- Incapacidade: é a restrição, resultante da deficiência, da habilidade para se desempenhar uma atividade considerada normal para o ser humano. A

\footnotetext{
* O paradigma social propõe as ações em saúde ampliadas e envolvendo aspectos do contexto histórico-social. Porém, é preciso ressaltar que - a partir do próprio cerne do paradigma social - as questões que envolvem o sujeito com deficiência não são campo de intervenção exclusivo da área da saúde; para a inclusão, todos os setores (educação, assistência social, trabalho, previdência, planejamento urbano, entre tantos outros) da sociedade devem estar envolvidos.
} 
incapacidade surge como conseqüência direta ou resposta do indivíduo à deficiência, representando a objetivação desta e, refletindo os distúrbios da própria pessoa nas suas atividades da vida diária;

- Desvantagem: é o prejuízo para o indivíduo, resultante de uma deficiência ou de uma incapacidade, que limita ou impede o desempenho de papéis de acordo com a idade, sexo, fatores sociais e culturais. A desvantagem caracteriza-se como uma discordância entre a capacidade individual de realização e as expectativas do indivíduo ou do seu grupo social, representando a socialização da deficiência.

Estes conceitos, para além do plano teórico, não são tão independentes como aqui apresentados; na prática as situações são sempre mais complexas e envolvem diversos aspectos. Ainda que incorpore avanços, segundo Diniz ${ }^{15}$, esta classificação ainda está pautada no modelo médico, como uma "extensão" da CID para as deficiências.

Em 1997, a OMS criou a CIDDM-2, "Classificação Internacional das Deficiências, Atividades e Participação: Um Manual da Dimensão das Incapacidades e da Saúde", propondo revisões aos termos utilizados anteriormente, na CIDID. Têm-se, então, algumas mudanças: o termo incapacidade passa a não ser mais utilizado, sob o entendimento de que ele implica desqualificação social, sendo substituído por atividade (aquilo que as pessoas fazem ou executam, em quaisquer níveis de complexidade); o termo desvantagem é substituído por participação, que é a interação que se estabelece entre a pessoa com deficiência, a limitação da atividade e os fatores do contexto sócio-ambiental.

Atualmente, a OMS propõe outra classificação: a "Classificação Internacional de Funcionalidade, Incapacidade e Saúde" (CIF). Ela representa 
um grande avanço na compreensão da deficiência, englobando o sujeito com deficiência, extrapolando o referencial orgânico/biomédico.

A CIF é estruturada em quatro eixos de classificação: função corporal (funções fisiológicas e psicológicas dos sistemas do corpo), estrutura corporal (partes anatômicas do corpo), atividades e participação (como o indivíduo exerce suas atividades diárias e se engaja na vida social), fatores ambientais (ambiente físico, social e de atitudes em que as pessoas vivem e conduzem suas vidas) ${ }^{16}$. Segundo Farias e Buchalla ${ }^{16}$, a CIF substitui o enfoque negativo da deficiência e da incapacidade por uma perspectiva positiva, na medida em que descreve a funcionalidade e a incapacidade a partir da identificação daquilo que o sujeito consegue e não consegue fazer em sua vida diária, constituindo-se um instrumento importante para a avaliação das condições de vida e para a promoção de políticas de inclusão social.

$\mathrm{Na}$ CIF, passa-se a compreender deficiência como pertencente aos domínios da saúde, mas não como conseqüência de doenças, e estes domínios são descritos com base no corpo, no indivíduo e na sociedade. Diniz ${ }^{15}$ ressalta que ela é um instrumento para descrever as situações em que se encontram as pessoas com deficiência (e não para identificar lesões/déficits). A deficiência é considerada um fenômeno de múltiplas causalidades, que se expande para outros domínios além do universo biomédico, como aspectos sociais, históricos e culturais.

De acordo com Ribas ${ }^{17}$ :

O mérito desse documento [CIF] é conseguir perceber que a deficiência é um tema que só pode ser estudado na transversalidade, ou seja, a deficiência é um acometimento que incide sobre crianças e adultos, homens e mulheres, brancos e negros, ricos e pobres, ocidentais e orientais, católicos e judeus. Tem graduações 
que vão da amputação de dedos a estados de vida vegetativos. Cruza momentos históricos, atravessa continentes, perpassa sociedades e culturas, origina-se em acidentes domésticos e em guerras monumentais. É atenuada ou agravada pelas circunstâncias que a cercam... (p.18).

A construção de conceitos e definições vai ampliando o entendimento em relação ao fenômeno da deficiência, ao considerar não apenas os aspectos orgânicos individuais, mas a ação do sujeito no mundo e sua relação com a cultura e o meio social. Possibilitam, portanto, complexificar as ações pretendidas.

O conceito de reabilitação também se modifica. Segundo a Organização Pan-Americana da Saúde (OPAS), em um conceito de 1991 apresentado por Rocha ${ }^{1}$ :

...la rehabilitación es un acto de atención de la salud y por lo tanto componente imprescindible de la promoción, prevención e asistencia de las personas en el mantenimiento de la salud y bienestar de ellos, su familia y la comunidad. Su ausencia implica una deficiencia del modelo de atención y en consecuencia el Sistema Local de Salud no se puede concebir sin que la rehabilitación forme parte del mismo (p.47).

É importante ressaltar que nesta definição a atenção à saúde da pessoa com deficiência não fica atrelada unicamente à reabilitação, mas sim a um sistema de saúde que deve oferecer propostas e ações em promoção, prevenção e assistência. Muitos autores que estudam a assistência à pessoa com deficiência, como os aqui citados, acabam atrelando o termo reabilitação a todo o conjunto de ações voltadas à saúde destas pessoas.

Em todo este percurso, no campo da produção teórica e da proposição de conceitos, Ghirardi ${ }^{12}$ chama a atenção para o âmbito semântico do uso dos 
termos, que também reflete estas mudanças. O termo "deficiente" vai sendo substituído por outras expressões como "pessoa deficiente", "pessoa portadora de deficiência" e "pessoa com deficiência"; fica implícito o deslocamento da lógica centrada no individuo para o caráter social implicado no fenômeno.

Segundo Sassaki ${ }^{18}$, o termo escolhido oficialmente pelos movimentos sociais e organizações civis é "pessoa com deficiência", em todos os idiomas. O termo é, inclusive, utilizado no texto da Convenção Nacional para Proteção e Promoção dos Direitos e Dignidade das Pessoas com Deficiência, da Organização das Nações Unidas (ONU), foi acordada entre todos os países-membros no ano de 2006.

O entendimento do processo de reabilitação também passa pelo mesmo movimento: primeiro fala-se da "inserção" das pessoas com deficiência; em um segundo momento, o termo "integração" surge nas discussões e textos; e, atualmente, o termo utilizado é "inclusão", no entendimento de um processo de duplo sentido, no qual tanto o sujeito quanto o seu contexto sociocultural devem se transformar e se adaptar na busca da possibilidade de se viver com as diferenças.

Palacios e Romañach ${ }^{13}$ trazem ainda outro conceito importante. No Fórum de Vida Independente, na Espanha, em 2005, foi proposta uma nova expressão: "diversidade funcional", ou mais especificamente, "homens e mulheres com diversidade funcional". Com esta expressão, está proposto um novo modelo de compreensão (e ação) da deficiência: o modelo da diversidade. Segundo os autores, este modelo avança nas limitações teóricas do modelo social, e está pautado em alguns princípios: desmedicalização da deficiência, desinstitucionalização, mudança da terminologia, dignidade e bioética. 
En esta propuesta terminológica, se busca un lugar intermedio que no se obvie la realidad. Las mujeres y hombres com diversidade funcional son diferentes, desde el punto de vista biofísico, de la mayor parte de la población. Al tener características diferentes, y dadas las condiciones de entorno generadas por la sociedad, se ven obligados a realizar las mismas tareas o funciones de una manera diferente, algunas veces a través de terceras personas. [...] Por eso el término 'diversidad funcional' se ajusta a una realidad en la que una persona funciona de manera diferente o diversa de la mayoría de la sociedad. Este término considera la diferencia de la persona y la falta de respeto de las mayorías, que en sus procesos constructivos sociales y de entorno, no tienen en cuenta esa diversidad funcional (p.107-108) $)^{13}$.

$\mathrm{Na}$ produção científica brasileira, Pereira ${ }^{19}$ aborda o termo diversidade funcional e suas potencialidades, destacando que esta é ainda uma terminologia recente, incomum no campo da saúde pública.

É fundamental ressaltar, porém, que na prática da assistência, não há um rompimento total de um referencial para outro; as diferentes concepções permeiam as ações e a própria relação da sociedade com a questão da deficiência.

\section{3 - Saúde da pessoa com deficiência no Brasil}

\footnotetext{
Segundo Ghirardi ${ }^{12}$, as primeiras instituições de reabilitação no Brasil surgiram na segunda metade do século XIX, essencialmente associadas à filantropia (e assim permaneceram até as primeiras décadas do século XX). Nas décadas de 1940 e 1950, há algum desenvolvimento destes serviços, voltado à idéia de restaurar a capacidade produtiva; há também influência de movimentos internacionais de reabilitação na ampliação destas práticas, porém ligadas às instituições filantrópicas e por iniciativa da sociedade civil.
} 
A atenção à saúde através do sistema de seguro social na década de 1960 deixava as pessoas com deficiência desassistidas, uma vez que apenas os trabalhadores formais que contribuíssem à previdência tinham acesso à assistência médica nos serviços públicos de saúde. Para elas, mantinha-se apenas a filantropia e outros serviços de baixa qualidade ${ }^{12}$.

Ainda que a industrialização crescente no país trouxesse um aumento na incidência de deficiências adquiridas (especialmente através de acidentes de trabalho), as políticas públicas funcionavam sob a lógica de repasse de recursos para a filantropia ${ }^{4}$. Configurava-se um panorama de assistência muito precária: recursos insuficientes, serviços concentrados em regiões de maior relevância econômica, modelo assistencial com baixa cobertura, pouca resolutividade e inadequado à realidade sócio-cultural das pessoas.

Através de intensa participação de movimentos sociais, a saúde pública passou por modificações e transformações conceituais, administrativas e operacionais. Diversas reformas institucionais sucederam-se, desde as "Ações Integradas de Saúde" (AIS), o "Sistema Unificado e Descentralizado de Saúde" (SUDS), até o "Sistema Único de Saúde" (SUS) ${ }^{20}$.

De acordo com Rocha ${ }^{1}$, os movimentos sociais das pessoas com deficiência (que incluíam os sujeitos, seus familiares e os profissionais da reabilitação) tiveram importância fundamental, reivindicando direitos sociais e igualdade de oportunidades. Estes movimentos nasceram pela influência de movimentos norte-americanos, surgidos principalmente no contexto pós Segunda Guerra Mundial, para reivindicação dos direitos e necessidades dos antigos combatentes, que voltavam para casa com seqüelas físicas e mentais. Segundo a autora, essas organizações populares no Brasil cresceram principalmente no período da Reforma Sanitária, nas décadas de 1970 e 1980, associando suas "bandeiras de luta" às demais existentes nesse momento da sociedade brasileira, 
ou seja: saúde, educação, fim da discriminação social e jurídica, transporte, pleno acesso aos espaços públicos, políticas públicas, etc. Além disso, também trouxeram à tona os questionamentos sobre os serviços existentes, com relação à qualidade e à resolutividade da assistência prestada.

Com a pressão destas mobilizações, o Estado passou a incorporar a temática da saúde da pessoa com deficiência como uma preocupação, propondo programas e políticas nacionais voltadas a esta população. Em meados da década de 1980, a Secretaria de Estado da Saúde de São Paulo implantou o "Sistema de Atendimento em Saúde e Reabilitação para Pessoas Deficientes". No âmbito federal, a criação da Coordenadoria Nacional Para Integração da Pessoa Portadora de Deficiência (CORDE), em 1986, também é um marco importante na conquista dos direitos desta população. É fundamental ressaltar que, como aponta Ghirardi ${ }^{12}$, a discussão do direito à saúde de forma a abranger também as pessoas com deficiência só surgiu a partir das lutas organizadas pelos movimentos e associações descritos anteriormente.

Foi com a Constituição de 1988 que a saúde passou a ser direito de todos e dever do Estado. A criação do SUS representou um grande avanço nas políticas e nas ações em saúde no Brasil, ao possibilitar que todas as pessoas tenham direito à saúde e garantia acesso aos serviços de saúde.

Universalidade, integralidade, equidade são alguns dos princípios norteadores do SUS e, segundo Cecilio ${ }^{21}$, envolvem aspectos que vão além do consumo e do acesso aos serviços e procedimentos em saúde, mas abarcam cidadania, saúde como direito de todos, e superação das injustiças resultantes da estrutura social. Assim, torna-se necessário repensar aspectos da organização dos processos de gestão, planejamento, construção e operatividade dos saberes e práticas na área da assistência à saúde. 
Já como parte do SUS, tem-se marcos importantes na área da assistência à saúde da pessoa com deficiência: "Programa de Atenção à Saúde da Pessoa Portadora de Deficiência" (1991), "Atenção à Pessoa Portadora de Deficiência no Sistema Único de Saúde - Planejamento e Organização de Serviços" (1993), "Política de Integração da Pessoa Portadora de Deficiência" (1999), "Política Nacional de Saúde da Pessoa com Deficiência" (2002), além de portarias que foram criadas para a regulamentação das diretrizes e práticas. Ghirardi ${ }^{12}$ completa que, já fruto das pressões e modificações, a saúde da pessoa com deficiência é proposta segundo o modelo assistencial geral e dos mesmos serviços utilizados por quaisquer cidadãos, o que representa um avanço. Alguns princípios e diretrizes trazidos nestes documentos serão apontados e discutidos a seguir, porém estes ainda se mantém distantes das práticas concretas.

Almeida et al. ${ }^{22}$ trazem que essas conquistas não interromperam o avanço de processos sociais de exclusão, que acabaram por aprofundar as contradições na sociabilidade desse segmento. Segundo Bernardes et al. ${ }^{3}$, ainda que os marcos legais tenham formalizado direitos fundamentais, mantiveram-se idéias de caráter assistencialista, que constituem entrave ao processo de inclusão social e participação no desenvolvimento do país. Para Almeida et al. ${ }^{22}$, a legislação propiciou algumas garantias, mas verifica-se a ausência de políticas que ofereçam suporte ao real exercício dos direitos. Bernardes et al. ${ }^{3}$ resumem:

Inegavelmente, a Constituição de 1988 trouxe avanços em relação às questões sociais, de garantia de direitos e de cidadania. Todavia, no que se refere às pessoas com deficiência, as decisões foram remetidas à regulamentação posterior e, ainda que o marco legal tenha formalizado direitos básicos e essenciais, mantiveram-se as idéias de caráter assistencialista - as quais já estavam cristalizadas na sociedade - e que constituem entrave ao processo de inclusão social e participação no desenvolvimento do país. (p.35). 
De acordo com Quintão ${ }^{23}$, no Brasil, há uma desvalorização das instâncias oficiais para com seus excluídos, uma vez que se manteve a política de repasse de recursos e o caráter caritativo-solidário nas ações e propostas governamentais. A assistência tende a continuar, portanto, associada à esfera filantrópica, com o modelo médico prevalecendo, tendo foco nos aspectos orgânicos e individuais da deficiência.

\subsection{1 - Legislação em Saúde da Pessoa com Deficiência}

Conforme já mencionado, a "Política Nacional de Saúde da Pessoa com Deficiência", instituída pela portaria MS/GM n. 1060/2002, foi um marco na atenção à saúde desta população no Brasil. É esta política que norteia o campo da saúde da pessoa com deficiência no SUS. Apresentá-la e discutir alguns de seus aspectos é importante para se visualizar como as mudanças abordadas até agora se traduziram em propostas e ações concretas.

Porém, antes desta discussão, é fundamental ressaltar que outros documentos e portarias importantes foram estabelecidos em âmbito nacional na área da atenção à saúde da pessoa com deficiência, sendo os mais importantes citados abaixo ${ }^{24}$.

- Atenção à Pessoa Portadora de Deficiência no Sistema Único de Saúde - Planejamento e Organização de Serviços", de 1993;

- "Política Nacional para Integração da Pessoa com Deficiência, lei 7853/89 e decreto 3298/99" (que também aborda a questão da saúde);

"Normas para atendimento hospitalar - SIH-SUS" (Portaria MS/SAS n. 303/1992); 
"Normas para atendimento ambulatorial - SIA-SUS" (Portaria MS/SAS n. 304/1992);

- Portaria para inclusão de reabilitação em nível hospitalar e ambulatorial (Portaria MS/SAS n. 306/1992 e Portaria MS/SAS n. 305/1992 e Portaria MS/GM n.1635/2002, sobre pessoas com deficiência mental);

- Concessão de órteses e próteses (Portaria MS/SAS n. 116/1993, Portaria MS/SAS n. 146/1993, Portaria MS/SAS n. 388/1999);

- Saúde da pessoa com deficiência auditiva (Portaria MS/GM n. 1278/1999 e Portaria MS/SAS n. 584/1999, sobre implante coclear, Portaria MS/SAS n. 432/2000 sobre outros procedimentos);

- "Redes Estaduais de Assistência à pessoa com deficiência física" (Portaria MS/GM n. 818/2001);

- Portaria MS/SAS n. 185/2001, fazendo uma atualização sobre diversos procedimentos;

- $\quad$ "Programa Nacional de Triagem Neonatal (PNTN)" (Portaria MS/GM n. $822 / 2001)$;

- "Programa de Assistência Ventilatória Não Invasiva a Portadores de Distrofia Muscular Progressiva" (Portaria MS/GM n. 1531/2001);

E ainda, depois de 2002, outras importantes leis foram estabelecidas, no campo da saúde da pessoa com deficiência:

- "Política Nacional de Atenção à Saúde Auditiva" (Portaria MS/GM n. 2073/2004), bem como a implementação de Redes Estaduais neste campo (Portaria MS/SAS n. 587/2004) e sobre inclusão/exclusão de procedimentos (Portaria MS/SAS 589/2004);

- Criação dos "Núcleos de Apoio à Saúde da Família" (Portaria MS/SAS n. 154/2008); 
Deve-se considerar ainda que, a partir das leis, portarias e diretrizes nacionais, Estados e Municípios também implementam suas normatizações, com especificidades para cada região.

Especificamente a "Política Nacional de Saúde da Pessoa Portadora de Deficiência" ${ }^{8}$ tem como objetivo reabilitar a "pessoa portadora de deficiência" na sua capacidade funcional e desempenho humano, de modo a contribuir para sua inclusão em todas as esferas da vida social, bem como proteger a saúde desta população e prevenir agravos que determinam o aparecimento de deficiências.

Segue o direcionamento teórico do Sistema Único de Saúde, baseando-se em princípios como direitos e cidadania, integralidade, hierarquização dos serviços, descentralização, interprofissionalidade, envolvimento da família / comunidade / contexto sócio-cultural, entre outros. Neste documento, surge a discussão sobre "promoção da saúde", ao trabalhar também sobre noções de ambientes favoráveis e promoção de hábitos e estilos de vida saudáveis.

As diretrizes que norteiam esta política são ${ }^{8}$ :

- $\quad$ Promoção da qualidade de vida das pessoas com deficiência

- Assistência integral à saúde

- Prevenção de deficiências

- Ampliação e fortalecimento dos mecanismos de informação

- Organização e funcionamento dos serviços específicos

- Capacitação de recursos humanos

Um tema recorrente neste documento é a informação/educação em saúde: menciona-se o fomento a ações de coleta e análise de dados sobre as deficiências e as condições de vida dos sujeitos que as têm; propõe-se a criação de sistemas de informação e banco de dados; ressalta-se a importância de campanhas educativas em diversos âmbitos, para divulgação do tema. O acesso 
dos cidadãos às informações (direitos, deveres, condições de sua doença, prognóstico, etc.) também é ressaltado como de extrema importância.

A Política discrimina as responsabilidades de cada nível de atenção com relação à assistência à pessoa com deficiência. Para a atenção primária (tratada no documento por atenção básica), cabem as ações de prevenção primária e secundária, detecção precoce de fatores de risco, atendimento às intercorrências gerais de saúde; e também as ações básicas em reabilitação, para favorecer a inclusão social. A unidade básica de saúde (UBS) é colocada como equipamento central na assistência às pessoas com deficiência, sendo porta de entrada para o sistema; ressalta-se a importância do sistema de referência e contra-referência.

Para o nível secundário, é proposta assistência a necessidades específicas advindas das incapacidades propriamente ditas, com tecnologias apropriadas e profissionais especializados. Já no nível terciário, os serviços devem estar estruturados por especificidade das deficiências e a tecnologia é de alta complexidade, com recursos humanos ainda mais especializados.

A definição de reabilitação da Política segue o Programa da Ação Mundial para Pessoas com Deficiência da ONU, voltado ao modelo biomédico, individual e com objetivo máximo de independência:

É um processo de duração limitada e com objetivo definido, com vista a permitir que uma pessoa com deficiência alcance o nível físico, mental e/ou social funcional ótimo, proporcionando-lhe assim os meios de modificar a sua própria vida. Pode compreender medidas com vista a compensar a perda de uma função ou uma limitação funcional (por exemplo, ajudas técnicas) e outras medidas para facilitar ajustes ou reajustes sociais $(\text { p.38 })^{8}$.

A assistência domiciliar, bem como a assistência odontológica, são trazidas como importantes para a saúde da pessoa com deficiência. A assistência domiciliar é colocada como essencial para o atendimento deste segmento, e 
compreende ações dos serviços de apoio à vida cotidiana até o oferecimento de suporte clínico especializado, de internação domiciliar.

Apesar das contradições existentes, em muitos trechos, fica explícito o entendimento da deficiência como uma condição social e também que o foco não pode estar apenas nos transtornos e danos funcionais do indivíduo, representando um avanço importante, fruto dos movimentos sociais relatados anteriormente.

Todas as medidas assistenciais voltadas à saúde da pessoa portadora de deficiência, incluindo a reabilitação, deverão levar em conta, sobretudo, as necessidades, potencialidades e recursos da comunidade, de modo a assegurar-se a continuidade e as possibilidades de autosustentação, visando, em especial, a manutenção da qualidade de vida deste segmento populacional e sua inclusão ativa na comunidade. Tal objetivo, no âmbito do setor saúde, será alcançado mediante, sobretudo, a reabilitação da capacidade funcional e do desempenho humano da pessoa portadora de deficiência $(p .08)^{8}$.

Pressupõe-se o modelo assistencial geral, através dos serviços utilizados por qualquer cidadão, o que é um avanço importante no direito, na cidadania e na compreensão das necessidades de saúde desta parcela. O atendimento deve ser integral em todos os seus sentidos, preconizando-se a qualidade de vida da pessoa com deficiência.

Além da Política Nacional, deve-se ressaltar outra importante portaria, que é a MS/GM n. 818, de 05 de junho de 2001, que cria as "Redes Estaduais de Assistência a Pessoa Portadora de Deficiência Física"24. Esta portaria determina os mecanismos de organização da assistência, financiamento e operacionalização dos serviços, nos diferentes níveis de complexidade (atenção básica, média e alta complexidade), bem como procedimentos e recursos (físicos e humanos) específicos para cada nível. 
De maneira geral, as Redes Estaduais são compostas por: Serviços de Reabilitação Física (Primeiro Nível de Referência Intermunicipal); Serviços de Reabilitação Física (Nível Intermediário); Serviços de Referência em Medicina Física e Reabilitação; Leitos de Reabilitação em Hospital Geral ou Especializado.

Em 28 de setembro de 2004, é instituída a "Política Nacional de Atenção à Saúde Auditiva"24, através da Portaria MS/GM n. 2073, pautada nas diretrizes de: cuidados integrais, ações transetoriais, ampliação da cobertura, melhoria dos estudos, pesquisas e da informação em saúde na área, bem como qualificação da assistência a pessoa com deficiência auditiva. Esta política também institui as responsabilidades nos diferentes níveis do sistema de saúde, sendo em linhas gerais as seguintes:

- Atenção Básica: Promoção da saúde auditiva, prevenção e identificação precoce de problemas auditivos, ações de informação, educação e orientação.

- Média Complexidade: Triagem e monitoramento auditivo, atenção diagnóstica e terapêutica especializada.

- $\quad$ Alta Complexidade: Diagnóstico e terapêutica especializados.

Na portaria MS/SAS n.587/2004 são criadas as "Redes Estaduais de Saúde Auditiva" 24 , com serviços de alta e média complexidade, discriminando-se a operacionalização destas redes, os procedimentos e os recursos (físicos e humanos) específica para cada nível. Na portaria MS/SAS n.589/2004, também relativa à Saúde Auditiva, é feita a exclusão e inclusão de procedimentos e nomenclaturas.

Em relação à saúde da pessoa com deficiência, é importante mencionar finalmente a portaria MS/GM n.154, de 24 de janeiro de 2008, que cria os "Núcleos de Apoio à Saúde da Família" - NASF ${ }^{25}$, considerando-se entre outros aspectos, a Política Nacional de Atenção Básica, de 2006, que regulamenta o desenvolvimento de ações de atenção básica e fortalece/preconiza a estratégia de Saúde da Família para isso. 
Os NASF são equipes especializadas para oferecer apoio às equipes básicas de saúde da família em áreas específicas. Entre elas, estão as ações de reabilitação, pautadas na Política Nacional, de 2004. Os objetivos de incluir as ações de reabilitação neste âmbito são: redução da incidência de incapacidades e deficiências; melhoria da qualidade de vida desta população, reinserção social, diminuição da discriminação e ampliação do acesso a serviços. Pauta-se, principalmente, na capacitação das equipes de saúde da família, para orientação, assistência e encaminhamento adequados.

As ações de reabilitação, responsabilidade dos NASF, são amplas e descritas de maneira detalhada, sendo especificadas a seguir ${ }^{25}$ :

- Diagnóstico e levantamento de problemas de saúde da região adstrita;

- Promoção e proteção da saúde, com vistas para o autocuidado;

- Acompanhamento do desenvolvimento infantil;

- Acompanhamento das crianças com risco no desenvolvimento;

- Orientação, atendimento e acompanhamento de usuários que necessitem de reabilitação;

- Ações de reabilitação, preferencialmente coletivas;

- Ações integradas aos equipamentos sociais;

- Visitas domiciliares, para orientação, atendimento e acompanhamento de pessoas com deficiência;

- Discussões de caso junto às equipes;

- Desenvolvimento de projetos e ações intersetoriais;

- Orientação a pessoas com deficiência, cuidadores e agentes comunitários de saúde, sobre posicionamento, atividades de vida diária e outras questões específicas relativas à deficiência;

- Ações de Reabilitação Baseada na Comunidade;

- Apoio e orientação aos familiares, desde o diagnóstico; 
- Acompanhamento do uso de equipamentos de ajuda, quando necessário;

- Encaminhamento e acompanhamento do uso de órteses e próteses;

- Ações para a inclusão escolar.

As políticas apresentadas pautam-se nos princípios do SUS, como hierarquização, regionalização, integralidade. Considerando-se os problemas no acesso a serviços e oportunidades vivenciados por esta população, e descrito por autores como Bernardes et al. $^{3}$, Almeida et al. $^{22}$ e Quintão ${ }^{23}$, é fundamental mencionar que a ampliação do acesso aos serviços, bem como da cobertura destes, é mencionada nestas portarias aqui descritas. Após 2006, com a Política de Atenção Básica e a preconização do Programa de Saúde da Família, ampliaram-se também as responsabilidades, possibilidades e ações junto às pessoas com deficiência no nível da atenção primária.

\section{4 - Necessidades de saúde}

A presente pesquisa trata do tema das necessidades da pessoa com deficiência, especialmente naquilo que tange à saúde; portanto, serão apresentadas algumas considerações acerca do conceito de necessidade. Um primeiro está publicado no dicionário Aurélio ${ }^{26}$ :

Necessidade. s.f. Aspiração natural e muitas vezes inconsciente: comer é uma necessidade fisiológica. / Desejo ardente. / O que é necessário. / Indigência, miséria. // Ter necessidade de, precisar. // Ter necessidade de alguém, de alguma coisa, sentir-lhe a falta. // Caso de necessidade, caso de força maior. // S.f.pl. Necessidades naturais, coisas indispensáveis à vida. 
Campos e Bataiero ${ }^{27}$ citam o conceito de necessidade formulado por Marx e Engels: aquilo que precisa ser satisfeito para que a vida continue. MendesGonçalves $^{28}$ afirma que as necessidades aparecem como aquilo que precisa ser satisfeito para que um ser continue sendo um ser, sabendo-se que, a toda necessidade, há um processo de trabalho correspondente, cujo produto potencialmente a satisfaz, reiterando-se ou ampliando-se esta necessidade, e dando origem a outro processo de trabalho. Para Campos e Mishima ${ }^{29}$, nessa perspectiva, as necessidades não são naturais nem iguais, pois desiguais são a distribuição e o consumo dos produtos do processo de trabalho. Ressalta-se que os indivíduos são sócio-historicamente determinados e que, portanto, as necessidades também são históricas e sociais, determinadas pela existência concreta dos mesmos.

Complementando estas definições e conceitos, Heller* apud Morais ${ }^{30}$ define necessidade como: desejo consciente, aspiração, intenção dirigida a todo o momento para certo objeto, que motiva a ação como tal, sendo o objeto em questão é um produto social, independentemente do fato de que se trate de mercadorias, de um modo de vida ou de outro homem.

No campo da saúde, a partir da concepção marxista, tem-se tomado o conceito de necessidades como projeto dos processos de trabalho em saúde, especialmente aquele operacional, que elege o objeto da atenção à saúde e organiza a produção de serviços ${ }^{27}$.

A procura ativa por intervenção e cuidados de saúde em um serviço é caracterizada como demanda, que também representa o consumo destes serviços; esta busca tem origem em um carecimento, ou seja, algo que o indivíduo entende que dever ser melhorado ou corrigido. O resultado das

\footnotetext{
*Heller, A. Teoria de las necesidades en Marx. Barcelona: Península, 1986.
} 
intervenções sobre este carecimento é reconhecido como uma necessidade de saúde, sendo a própria intervenção também reconhecida como tal ${ }^{31}$.

Nas palavras de Cecilio $^{21}$ : a demanda é o pedido explícito do usuário, modeladas pela oferta feita pelos serviços. As necessidades de saúde são as traduções realizadas pela equipe conjuntamente com este usuário, no processo de intervenção em saúde, ressaltando que as mesmas são social e historicamente determinadas. Silva et al. ${ }^{32}$ propõem mais uma ampliação no conceito de demanda, entendendo-a como uma relação e uma interação entre atores que têm necessidades, desejos e projetos institucionais distintos, e que portanto - devem ser considerados para a definição das necessidades.

Sobre os atores e suas relações, Merhy ${ }^{33}$ apresenta três atores fundamentais no conjunto das ações em saúde: os usuários com suas necessidades, os trabalhadores com suas tecnologias e os gestores com sua capacidade de governar recursos. Mesmo os usuários sendo os portadores do "mundo das necessidades de saúde" (e este o foco do trabalho produzido e aqui apresentado), o autor pondera que este mundo será representado das mais variadas formas, sendo condicionado pela relação com os outros dois atores (e o mesmo ocorre na ação destes outros).

Stotz ${ }^{*}$ apud Silva et al. $^{32}$ afirma que as necessidades de saúde situam-se no nível das necessidades sociais mais gerais. $E$, ainda que determinadas e construídas social e historicamente, só poderão ser apreendidas em sua dimensão individual, em uma relação dialética entre o individual e o coletivo. Silva et al. ${ }^{32}$ pontuam que o indivíduo compartilha o processo de determinação de suas necessidades, na medida em que pertence a certo grupo e por ele é influenciado e, portanto, tem-se as tais dimensões coletivas.

* STOTZ, E.N. Necessidades de saúde: mediações de um conceito (contribuição das Ciências Sociais para a fundamentação teórico-metodológica de conceitos operacionais da área de Planejamento em Saúde. 1991. Tese (Doutorado) - Escola Nacional de Saúde Pública, Fundação Oswaldo Cruz, Rio de Janeiro. 


\begin{abstract}
Campos e Mishima ${ }^{29}$ trabalham com o conceito de que os processos de trabalho deveriam tomar como finalidade o atendimento às necessidades de saúde dos grupos sociais que constituem um território.
\end{abstract}

Para a saúde coletiva, atender essas necessidades deveria significar tomar o conceito da determinação social do processo saúde-doença para instaurar processos de trabalho que respondessem por elas no âmbito das raízes dos problemas, do determinante, e também no dos resultados, a doença propriamente dita, e encaminhar a política pública de saúde na direção do direito universal. (p.1261).

Segundo Schraiber e Mendes-Gonçalves ${ }^{31}$, as necessidades de saúde são um aspecto importante para produzir reflexões sobre os serviços e as referências que os embasam. E o tema tem sido bastante explorado: em pesquisa bibliográfica na bases de dados eletrônica LILACS (Literatura Latino Americana e do Caribe em Ciência da Saúde), utilizando-se descritores associados ao tema das necessidades da saúde, Campos e Bataiero ${ }^{27}$ encontraram 82 produções relacionadas, sendo selecionadas 73 para análise. A partir de categorias de análise estabelecidas pelos autores, verificou-se que a produção de dados sobre o tema no Brasil estão assim organizadas quanto ao seu objeto/objetivo: $61,6 \%$ das publicações abordavam a oferta/demanda de ações nos serviços, sob o aspecto das necessidades associadas ao consumo; $28,8 \%$ traziam o tema pela ótica da administração e do planejamento dos serviços de saúde, tendo o conceito de necessidade como um instrumento para tal; apenas 9,6\% abordavam a ótica conceitual, seja para a produção de serviços, processos de trabalho ou ampliação do objeto de atenção ${ }^{27}$.

Em outra pesquisa, realizada com usuários e trabalhadores de uma Unidade Básica de Saúde, Campos e Mishima ${ }^{29}$ produziram três categoriais de 
necessidades, a partir da voz destes sujeitos: necessidade de presença do Estado (como responsável pela garantia dos direitos e acesso aos serviços); necessidades de reprodução social (condições de vida, inserção no trabalho, atividades produtivas); necessidade de participação política (possibilita a discussão e o embate das necessidades e interesses dos diferentes grupos).

Já Cecilio ${ }^{21}$ apresenta outra taxonomia das necessidades de saúde, em quatro grandes conjuntos. Ainda que maneiras diferentes de viver levem a diferentes necessidades de saúde, "ter boas condições de vida" é um primeiro conjunto de necessidades. Acesso ao consumo de tecnologias capazes de melhorar e/ou prolongar a vida é outra dimensão, ressaltando que as tecnologias são várias (leve, leve-dura, dura), e não deve haver hierarquização entre elas, uma vez que necessidades são diferentes em momentos diferentes.

A criação de vínculos "(a)efetivos" entre usuários e profissionais é considerada pelo autor uma outra categoria das necessidades de saúde, no entendimento de que a relação entre usuários e profissionais/serviços não deve se restringir a adscrição da clientela, mas sim considerar um verdadeiro encontro de subjetividades. Ter graus crescentes de autonomia nos "modos de andar a vida" é a última categoria trazida pelo autor, entendida aqui como a reconstrução dos sentidos da vida após o processo de adoecimento e da possibilidade de fazer escolhas acerca de sua vida, pelos próprios sujeitos ${ }^{21}$.

Complementando esta taxonomia, Merhy ${ }^{33}$ acrescenta a "necessidade de ser alguém singular com direito à diferença", isto é, ser sujeito de direitos e cidadão, mas ser nominal, ser respeitado em suas necessidades especiais, ser incluído.

Por fim, assim como Cecilio $^{21}$, ressalta-se a potencialidade que o conceito de necessidades de saúde tem de ajudar os profissionais, equipes e serviços a 
fazer uma melhor escuta das pessoas que buscam cuidados em saúde, tomando suas necessidades como centro de suas intervenções e práticas.

\section{5 - Necessidades de saúde das pessoas com deficiência: uma leitura possível}

Tomando estes conceitos apresentados, é possível fazer uma leitura dos modelos de intervenção propostos pelos autores da área da reabilitação e da saúde da pessoa com deficiência. São diferentes modelos, alguns pautados em um paradigma médico, outros no paradigma social, mas que fazem uma leitura da demanda trazida pelo o usuário, traduzindo-se na compreensão de necessidades de saúde bastante diferentes.

Rocha ${ }^{1}$ chama de concepção ortopédica um modelo de ação que privilegia as abordagens de correção corporal por meio de técnicas cirúrgicas ou aparelhos, tendo como objetivo final a restituição da estrutura corpórea normal. O corpo é uma montagem de partes separadas, a deficiência está localizada no indivíduo e o corpo deficiente deve ser passível de correção.

Nesta perspectiva, as necessidades de saúde de uma pessoa com deficiência estão no corpo e, mais do que isso, na correção anatômica-estrutural deste corpo.

É também apresentada por Rocha ${ }^{1}$ a concepção fisiátrica, que é centrada no corpo e no indivíduo, mas volta seu olhar para a funcionalidade desta pessoa enquanto capacidade do corpo em executar atividades. Mantém-se também o corpo individual que deve ser adaptado ao que lhe é requerido socialmente.

A funcionalidade do corpo é a principal necessidade de saúde da pessoa com deficiência nesta abordagem. Ambas as perspectivas (ortopédica e 
fisiátrica) estão pautadas no paradigma médico de compreensão e ação sobre a deficiência; são modelos tradicionais de atenção à saúde da pessoa com deficiência, já bastante questionados, mas que ainda permanecem em muitos espaços assistenciais.

A Reabilitação Baseada na Comunidade $(R B C)$ é outro modelo de atenção à saúde da pessoa com deficiência, colocado como proposta assistencial para os serviços de atenção primária, e existente no SUS. Foi criada pela OMS e surgiu no contexto de reivindicações dos diretos das pessoas com deficiência, no final da década de 1970, sendo concebida como uma contraposição à organização de serviços de reabilitação baseados no paradigma médico. Foi proposta como um modelo de ampliação da cobertura assistencial e para o combate à segregação e ao internamento das pessoas com deficiência ${ }^{34}$.

Diversos autores, como Rocha ${ }^{1}$, Almeida et al. $^{2}$, Ghirardi ${ }^{12}$ e Oliver et al. ${ }^{34}$, abordam a importância deste modelo na reconstrução da assistência a esta população, compreendendo como principal necessidade de saúde a inclusão do sujeito em seu meio familiar e sócio-cultural, não estando mais no corpo o foco da intervenção.

Para Rocha ${ }^{1}$, esta é uma concepção de intervenção que busca primordialmente a inserção no social. Nesta perspectiva, segundo Oliver et al. ${ }^{34}$, um dos principais objetivos das ações devem ser dar visibilidade social às pessoas com deficiência, implicando em possibilidades de circulação e participação social; além disso, deve haver uma valorização dos processos e recursos locais para a construção da inclusão, pois os profissionais estão diante de um sujeito com saberes, valores, vontades e história, que pertence e pode agir sobre o contexto sociocultural. Almeida et al. ${ }^{2}$ ressaltam a importância de se atuar na construção de trocas sociais, tendo como horizonte ético a igualdade e o respeito às diferenças. 
Oliver et al. ${ }^{35}$ elencam ainda outros eixos para a prática: garantia de direitos, construção de redes de apoio social, criação de oportunidades de ampliação da sociabilidade e participação comunitária. As autoras enfatizam a importância da construção compartilhada - usuários, técnicos e comunidade destes processos.

Entretanto, embora o modelo de RBC tenha gerado experiências práticas que dão materialidade a novos princípios e diretrizes para a assistência às pessoas com deficiência, ele não se desenvolveu de forma a produzir a superação dos limites impostos pelo paradigma médico na compreensão e intervenção sobre as deficiências ${ }^{22}$.

Ghirardi $^{12}$, pautada em referenciais que discutem a reabilitação psiquiátrica, traz a reabilitação psicossocial como outro possível modelo de ação no âmbito da saúde da pessoa com deficiência, já que critica os modelos tradicionais e busca criar novas estratégias de atuação no campo da reabilitação.

Segundo Saraceno ${ }^{36}$, importante autor da reabilitação psicossocial, reabilitar significa muito mais que passar um paciente de um estado de incapacidade para um estado de capacidade. Para ele: "O processo de reabilitação seria, então, um processo de reconstrução, um exercício pleno da cidadania, e, também, de plena contratualidade nos três grandes cenários: habitat, rede social e trabalho com valor social" (p.16). A proposta da reabilitação psicossocial é a construção da cidadania plena para aquele sujeito que tem deficiências, incapacidades e/ou desvantagens.

Nesta perspectiva, o sujeito deve ser ajudado a gerir sua existência a partir de seu desejo e de sua subjetividade, sendo protagonista dos diversos cenários de sua vida ${ }^{12}$. Novamente desloca-se o foco do corpo e do indivíduo, mas da relação deste sujeito com seu meio sócio-cultural, e as necessidades de saúde da pessoa com deficiência serão compreendidas nesta relação. 
Ainda como modelo de compreensão/ação que busca superar as práticas tradicionais, de cunho biomédico, Rocha ${ }^{1}$ traz a concepção de Vida Independente, uma abordagem de reabilitação que pretende colocar recursos tecnológicos à disposição da pessoa com deficiência, com intervenções individuais e ambientais. Volta-se o olhar para situações específicas da vida da pessoa, que é vista como um consumidor e os profissionais como auxiliares em seu processo de decisão. A tecnologia que trará a equiparação de oportunidades para todos, otimizando-se a relação do homem com seu meio.

Assim, nesta perspectiva, as necessidades de saúde estão postas no consumo das chamadas tecnologias assistivas*. Ainda que esta concepção traga o rompimento com a idéia de corpo e normalidade, e considere os aspectos sócio-relacionais da deficiência, faz poucas proposições que envolvem mudanças na relação com a diferença e movimentos de construção de autonomia e cidadania.

Vale ressaltar que estes modelos são construções teóricas que embasam diretamente as práticas. Todos convivem, a partir das instituições, dos referenciais de cada profissional e das representações e concepções sociais e culturais sobre a deficiência.

\begin{abstract}
Rocha $^{37}$ apresenta um estudo sobre as demandas de pessoas com deficiência (ou seus cuidadores) que procuraram um ambulatório de atendimento a esta população na cidade de São Paulo. No total dos atendimentos iniciais de 65 usuários deste ambulatório, no período entre 19931998, foram identificadas 127 queixas que, inter-relacionadas, foram classificadas da seguinte maneira:
\end{abstract}

\footnotetext{
* Tecnologia Assistiva: qualquer item, peça de equipamento ou sistema de produtos, adquirido comercialmente ou desenvolvido artesanalmente, produzido em série, modificado ou feito sob medida, que é usado para aumentar, manter ou melhorar habilidades de pessoas com limitações funcionais, sejam físicas ou sensoriais.
} 
- Pedidos relacionados à melhora do aspecto motor (23\%);

- Pedidos relativos à inclusão social (22\%);

- Solicitação de serviços específicos de reabilitação (20\%);

- Pedido de ajuda em aspectos cognitivos, psicológicos e/ou comportamentais (13\%);

- Com dúvidas sobre o diagnóstico e prognóstico (8,5\%);

- Intervenção junto à família $(8,5 \%$;

- Outras (5\%).

A autora ressalta que o trabalho da assistência é desvelar o sentido destas queixas, pois aí reside o problema a ser "resolvido" no processo de reabilitação. A intenção é, segundo a autora, entender as razões da procura de um serviço de reabilitação, em relação à história pessoal e familiar, permitindo depreender o sentido que está sendo atribuído à instituição pelos usuários (e provavelmente por seus técnicos também).

Ou seja, conforme mencionado anteriormente, as necessidades de saúde destes usuários são as traduções feitas pela equipe conjuntamente com o usuário, no processo de intervenção em saúde.

Em pesquisa qualitativa realizada com surdos, Santos e Shiratori ${ }^{38}$ afirmam que - em relação a esta população - há necessidades de saúde extrínsecas (comum a toda sociedade, independente da deficiência) e necessidades intrínsecas (relacionadas a este grupo social específico). O acesso aos serviços de saúde é apontado como uma necessidade desta população, bem como esclarecimento acerca de diversas questões de saúde, como planejamento familiar, doenças sexualmente transmissíveis, doenças crônicas, uso de medicações, etc. No aspecto específico, a comunicação é identificada como principal necessidade, ao mesmo tempo em que é a principal barreira encontrada pelas pessoas com deficiência auditiva. 
Deve-se considerar que as demandas trazidas englobam todo o conjunto de necessidades comentadas, isto é, não é apenas no corpo, na inclusão social e nas tecnologias de apoio que residem as queixas levantadas pelos usuários, mas neste conjunto de aspectos, organizados de forma complexa. Nas ações em saúde, é preciso considerar esta complexidade e, ao mesmo tempo, compreender que as intervenções terão limites, a partir do referencial teórico, dos recursos humanos e materiais disponíveis, etc.

\section{6 - Diálogos com o campo da Saúde Coletiva: cuidado e integralidade.}

Ter o conceito de necessidade de saúde como norteador para a assistência em saúde possibilita a abertura de um espaço para uma escuta mais qualificada das falas dos usuários. Neste trabalho, adota-se a taxonomia proposta por Cecilio $^{21}$, na qual as necessidades de saúde envolvem quatro categorias principais: resposta às más condições de vida, vínculo com profissional, necessidade de maior autonomia ou ainda acesso às tecnologias disponíveis, abordadas anteriormente, bem como a inclusão proposta por Merhy ${ }^{33}$ : necessidade de ser alguém singular com direito à diferença.

Obviamente, as respostas a esta gama de necessidades, e seus múltiplos fatores envolvidos, não se restringe à atuação de um único profissional, ou mesmo somente da área da saúde. As ações devem ser multiprofissionais, interdisciplinares e intersetoriais, para que sejam possíveis respostas mais efetivas às necessidades de saúde das pessoas. Cecilio ${ }^{21}$ afirma que deve haver uma articulação entre as diversas áreas, através de ações integrais.

Para Mattos ${ }^{39}$, o conceito de integralidade tem três conjuntos possíveis de sentido, relacionando-se: à prática do profissional na assistência ao usuário, à 
organização do trabalho em saúde, e à formulação de políticas e programas em saúde.

No primeiro conjunto, o autor menciona a articulação entre a prevenção e a assistência, a importância para a abertura a outras necessidades do sujeito (não necessariamente ligadas à doença), além da importância do trabalho interdisciplinar não focado exclusivamente no aspecto biomédico. Com relação à organização do trabalho, é ressaltada a organização dos serviços para a abertura a novas necessidades dos usuários, com diálogo constante entre os diferentes sujeitos envolvidos, seus diferentes modos de viver e de apreender/perceber suas próprias necessidades.

A formulação de políticas e programas em saúde deve preconizar a ampliação dos horizontes, sem recortar os sujeitos-alvo; a articulação entre prevenção e assistência deve estar presente, abarcando os diferentes grupos atingidos pelo problema e respeitando suas especificidades ${ }^{39}$.

Lacerda e Valla ${ }^{40}$ apontam o cuidado como uma dimensão da integralidade, incluindo o acolhimento, os vínculos de intersubjetividade e a escuta dos sujeitos. Para Ayres ${ }^{41}$, o cuidado deve ser entendido como: "designação de uma atenção à saúde imediatamente interessada no sentido existencial da experiência de adoecimento, físico ou mental, e, por conseguinte, também das práticas de promoção, proteção ou recuperação da saúde" (p.22).

Conforme já abordado, é indiscutível que o SUS possibilitou mudanças na atenção à saúde da pessoa com deficiência, uma vez que passaram a ter seus direitos reconhecidos pela Constituição, devendo suas necessidades de saúde ser atendidas nos serviços utilizados por todos os cidadãos, não mais em situação de isolamento e segregação. Como trazido por Mattos ${ }^{42}$, o acesso é uma primeira dimensão da integralidade e esta garantia é fundamental na assistência a este 
grupo populacional, pois se encontram em condição de isolamento e segregação social.

A integralidade é principio norteador para a apreensão das necessidades dos sujeitos atendidos, bem como para a compreensão e formulação das respostas a serem dadas, incluindo aspectos muito importantes: as necessidades não se resumem à doença; a prevenção e a assistência devem estar articuladas, os problemas são complexos e envolvem o contexto sociocultural, o usuário é um sujeito (com história, valores, desejos).

Porém, a reabilitação praticada nas instituições médico-especializadas existentes, mostra que a racionalidade médica, com a organização do trabalho da equipe e as modalidades de assistência prestada, institui a melhora ou o aumento do desempenho funcional como missão exclusiva, pouco abordando os processos que envolvem a vida com deficiência ${ }^{22}$. E, articuladamente a isso, o modelo traz a propagação da idéia de que a integração social dependeria fundamentalmente - de conquistas individuais ${ }^{22}$.

Segundo Lacerda e Valla ${ }^{40}$, o modelo médico é pautado no diagnóstico e tratamento de doenças definidas pelo saber científico, priorizando-se as alterações e lesões do corpo, em detrimento do sujeito e suas necessidades. Há pouco espaço para a escuta dos sujeitos e seus sofrimentos, para o acolhimento e para a atenção e cuidado integral à saúde.

Ayres $^{41}$ considera que $o$ horizonte normativo desse modelo é a morfofuncionalidade, e a escuta será orientada para obter dados objetivos, considerando-se os aspectos ligados à situação existencial do sujeito apenas como elementos subsidiários, ou até mesmo ruídos nesta comunicação. No 
contexto das práticas em saúde, o modelo médico hegemônico contribui para o "não-diálogo". Malta e Merhy* apud Morais ${ }^{30}$ destacam:

... No encontro do trabalhador de saúde com o usuário estabelece-se entre eles um espaço intercessor, de relação, onde ocorre a produção e o consumo dos atos de saúde. Porém, no modelo de assistência a saúde hoje predominante, os espaços intercessores são preenchidos pela 'voz' do trabalhador e pela 'nudez' do usuário. (p.38).

E, na prática da assistência em saúde às pessoas com deficiência, é possível identificar que, muitas vezes, as principais demandas e necessidades não estão na gravidade orgânica ou nos comprometimentos funcionais, mas sim em outros processos, sociais e relacionais, que condicionam desigualdades entre os cidadãos, havendo a necessidade de responder a isso do ponto de vista da organização dos serviços e práticas².

Abordando a problemática da pessoa com transtorno mental, Mota ${ }^{43}$ traz aspectos que também estão relacionados às pessoas com deficiência:

... São duplamente desfavorecidos: primeiro por se tratarem de pessoas pobres, pelo menos a maioria dos que se fazem tratamento nos serviços públicos de saúde mental, portanto as únicas necessidades possíveis de satisfação são as artificiais; e, segundo, porque o serviço responsável pelo seu tratamento não leva em consideração suas necessidades, já que, normalmente, se identificam com a norma estabelecida e têm função de manter a ordem. (p.26).

Diante disso, Ayres $^{41}$ propõe a ampliação do horizonte normativo para a dimensão existencial do adoecimento (e, portanto, da condição do existir com deficiência), relacionada diretamente com o conceito de cuidado, trazido

* Malta, D.C.; MERHY, E.E. A micropolítica do processo de trabalho em saúde - revendo alguns conceitos. Rev. Min. Enf. 2003. 7(1): 61-66. 
anteriormente. Propõe um diálogo entre a normatividade morfofuncional (que tem seu papel fundamental, sem dúvida) e uma normatividade de outra ordem, implicando na abertura de autêntico interesse em ouvir o outro, e todas as demandas que ele possa trazer.

Considera-se que as práticas são intersubjetivas, e com isso, o sujeito não pode ser reduzido à doença ou à deficiência. Para Mattos ${ }^{42}$, os profissionais devem considerar o saber técnico-científico, mas também os modos de andar a vida do sujeito que ali está (que não são necessariamente de conhecimento do profissional). Conforme posto por Merhy ${ }^{33}$, há a necessidade de ser singular. E, "Isso implica a busca de construir, a partir do diálogo com o outro, projetos terapêuticos individualizados" (p.1415) ${ }^{42}$, projetos estes que emergem da negociação e da comunicação, e que articulem dimensões assistenciais e preventivas. Os sofrimentos devem estar como mais alta prioridade das ações em saúde; o compromisso deve ser com o bem-estar do sujeito, e a história de vida, os projetos, os desejos, as relações, as diferenças devem ser contempladas na assistência.

A noção de projeto de felicidade, trazida por Ayres $^{41}$ como a referência principal para definir a responsabilidade do profissional de saúde no encontro com aquele a ser cuidado, configura este outro horizonte normativo, colocando como necessário e imprescindível que a busca por aquilo que as pessoas querem e acham que devem ser a atenção à saúde, em um movimento dialógico com o olhar e os referenciais dos profissionais (sejam técnicos ou práticos).

É preciso radicalizar a idéia de que cada usuário, com suas múltiplas e singulares necessidades, seja sempre a razão de ser do sistema de saúde ${ }^{21}$. Estas ações, sob o ponto de vista do cuidado à saúde e à vida, são bastante complexas e ainda se constituem como um grande desafio. 
Silva et $a^{32}$ reiteram que, para a concretização da integralidade, é preciso uma articulação entre os diferentes setores da sociedade, entre ações e serviços:

A integralidade, em seu sentido ampliado, constitui 'objetivo de rede' e sua concretização depende de uma articulação entre a micro e a macro política, e não apenas do espaço singular dos serviços - mesmo que estes cumpram sua função social a contento. Para ser alcançada, depende de uma articulação entre serviços e ações setoriais e intersetoriais (p.239).

Lacerda e Valla ${ }^{40}$ complementam que ser doente pode representar uma vida diferente, sendo o sujeito excluído de atividades e papéis sociais que desempenhava, sentindo-se impotente e ameaçado; estas são questões fundamentais a serem consideradas na assistência as pessoas com deficiência, que vivenciam rupturas em suas vidas, muitas incapacidades no fazer cotidiano, além do isolamento e preconceito.

Para a real ampliação do horizonte normativo, é preciso considerar que a relação terapêutica não começa exatamente no primeiro encontro, pois profissionais e usuários trazem consigo papéis e sentidos carregados de significados. E, portanto, faz-se necessário criar um movimento de desconstrução das "identidades-alteridades" que já mediam e subsidiam estes encontros ${ }^{41}$.

No campo da deficiência, isso traz implicações específicas, como posto por Ghirardi ${ }^{12}$ :

Nossa consciência atual, ou nossa maneira de estar em contato com esse outro que é tão diverso de nós, está certamente permeada por esse legado de representações que fizeram do louco e do deficiente, ao longo da história, 
figuras ora temidas e amaldiçoadas, cujo fim era a exclusão do convívio social, ora vistas como seres semidivinos, cuja existência era de alguma forma tida como redentora dos males sociais, sendo, portanto, objeto de atenção e de caridade de grande parte da comunidade (p.32).

São diversos os serviços e proposições existentes no campo da atenção à saúde da pessoa com deficiência. Mas, como disse $A y r e s^{41}$, as práticas em saúde - apesar de um grande desenvolvimento técnico-científico - encontram limitações para responder efetivamente às complexas necessidades de saúde das pessoas, sendo necessários novos referenciais para a assistência, pautados por conceitos como integralidade e cuidado.

Segundo Mattos ${ }^{39}$ :

... As necessidades de serviços assistenciais de uma população não se reduzem às necessidades de atendimento oportuno de seus sofrimentos. Como também não se reduzem às necessidades de informação e de intervenções potencialmente capazes de evitar um sofrimento futuro. As necessidades não se reduzem àquelas apreensíveis por uma única disciplina, como a epidemiologia, ou a clínica. Novamente, o princípio da integralidade implica em superar reducionismos. [...] As respostas aos problemas de saúde devem abarcar suas mais diversas dimensões. Analogamente, devem oferecer respostas aos diversos grupos atingidos pelo problema em foco. [...] Então integralidade talvez só se realize quando procurarmos estabelecer uma relação sujeito-sujeito, nas nossas práticas nos serviços de saúde, nos debates sobre a organização dos serviços, ou nas discussões sobre as políticas. Isso talvez envolva uma abertura para o diálogo com o outro, que sempre resiste aos nossos projetos, do mesmo modo como resistimos aos seus projetos... (p.64).

Em uma sociedade de exclusão e preconceito, pensar o diálogo e as práticas intersubjetivas é um grande desafio. Que voz tem as pessoas com deficiência? Construir espaços de inclusão traz desafios, pois convoca a 
sociedade a lidar com suas dores, remetendo seus cidadãos à condição de incompletos, imperfeitos, seres faltantes... ${ }^{23}$.

É preciso trazer para o primeiro plano das discussões teóricas e práticas, as demandas e necessidades de saúde identificadas pelas próprias pessoas com deficiência, em seus contextos de vida, possibilitando diálogo e reflexão com os referenciais que subsidiam as ações neste campo. Novas práticas precisam ser inventadas, aquelas que abram os canais para a complexidade, a polifonia, a multiplicidade, as diferenças. Ou, como reiterado por Ribas ${ }^{17}$, é preciso construirmos um mundo em que as diferenças entre as pessoas sejam o esteio da riqueza da humanidade. É neste contexto que esta pesquisa se inscreve... 


\section{Objetivo}

Identificar quais são as demandas e necessidades de saúde das pessoas com deficiência, a partir da ótica destes sujeitos. 


\section{Metodologia}

A partir do objetivo estabelecido de identificar quais são as demandas e necessidades de saúde das pessoas com deficiência, a partir da ótica dos próprios sujeitos, adotou-se a metodologia qualitativa de pesquisa, considerada mais adequada por se preocupar em compreender a dinâmica das relações sociais, abrangendo suas crenças, valores, atitudes e hábitos. A pesquisa qualitativa trabalha com a experiência, com a cotidianidade e também com a compreensão das instituições como resultado da ação humana ${ }^{44}$, ou seja, este é um tipo de pesquisa que busca verdades acerca da experiência humana.

Dentro do contexto da pesquisa qualitativa, a história de vida foi adotada como técnica de produção de dados. Esta se caracteriza por colher informações da vida pessoal dos indivíduos, sendo relatadas suas percepções pessoais, os aspectos que marcaram sua experiência, os acontecimentos vividos em suas trajetórias ${ }^{45}$.

Trabalhar com histórias de vida é trabalhar com as narrativas destes sujeitos e, portanto, com sua memória. E, de acordo com Bosi ${ }^{46}$, a memória do indivíduo depende de sua história: seus relacionamentos, sua classe social, sua profissão, ou seja, seus grupos de convívio e os grupos de referência que tenha. Segundo a mesma autora, o processo da memória não é apenas reviver as experiências passadas, mas refazê-las, reconstruí-las, a partir das imagens e das idéias do presente.

Queiroz ${ }^{47}$ completa sobre o método da história de vida:

A história de vida, por sua vez, se define como o relato de um narrador sobre sua existência através do tempo, tentando reconstituir os acontecimentos que vivenciou e transmitir a experiência que adquiriu. Narrativa linear e 
individual dos acontecimentos que ele considera significativos, através dela se delineiam as relações com os membros de seu grupo, de sua profissão, de sua camada social, de sua sociedade global, que cabe ao pesquisador desvendar. Desta forma, o interesse deste último está em captar algo que ultrapassa o caráter individual do que é transmitido e que se insere nas coletividades que o narrador pertence (p.275).

A partir das entrevistas, em que o narrador sai da imediatez cotidiana e reflete sobre sua própria história, haverá uma articulação entre a experiência individual e coletiva, entre o presente e o passado, entre as dimensões objetivas e subjetivas. E, assim, segundo Schraiber ${ }^{48}$, o coletivo é expresso e explorado pela reconstrução pessoal daquele sujeito, a partir de sua posição e de sua interpretação.

Gonçalves e $\operatorname{Lisboa}^{49}$ corroboram esta afirmação, reiterando que há um entrelaçamento pessoal e social na narração das histórias de vida. Elas são um relato de um sujeito imerso em uma cartografia cultural e social, e que com sua singularidade, rearranja e se reapropria do social.

Camargo $^{50}$ ressalta que a técnica da história de vida é muito utilizada em trabalhos relacionados às minorias sociais e étnicas, tendo como objetivo principal revelar este grupo "do lado de dentro", e podemos considerar as pessoas com deficiência nesta categoria. Gonçalves e Lisboa ${ }^{49}$ complementam que a história de vida pode "dar voz a sujeitos invisíveis" e, por meio de seus depoimentos singulares, construir e preservar a memória coletiva deste grupo.

Caiado $^{10}$ pondera sobre o método, afirmando que a opção política de dar "voz aos excluídos" não é intrínseca ao método da história de vida, pois ela também é utilizada como recurso metodológico para legitimar a voz do poder, a partir do referencial do pesquisador. Nesta pesquisa aqui apresentada, a opção pela história de vida deu-se pelo método possibilitar oportunidades de escuta das pessoas com deficiência e sua ótica de necessidades. 
A entrevista se construirá como um encontro dialógico entre entrevistado e pesquisador, que se revêem e se (re)constroem a partir da pesquisa em ato ${ }^{48}$. Porém, ainda que tenha sido escolhida uma técnica aberta, de relato livre do entrevistado, há uma direção do relato, de acordo com os objetivos da pesquisa. Segundo Houltz ${ }^{51}$, é preciso considerar que o entrevistado tem um movimento de "ajuste" de seu relato, no sentido daquilo que acredita ser o interesse do outro, sendo este conteúdo manifesto ou latente.

Com isso, é possível pontuar que o objetivo de utilizar a história de vida nesta pesquisa é captar o grupo, a coletividade das pessoas com deficiência, a partir dos sujeitos participantes. Este método de produção de dados potencializa o registro destas histórias, que pouco aparecem nos manuais de saúde mais tradicionais, apesar das conquistas sociais deste grupo, já relatadas no capítulo sobre referencias teóricos.

Enfim, Caiado ${ }^{10}$ resume os referenciais de escolha deste método:

Opção científica metodológica que busca pensar um homem concreto, que se relaciona numa determinada sociedade, que sofre as limitações do seu tempo e lugar social; um homem criativo e construtor desse mesmo tempo que o limita e que ele, dialeticamente, transforme. Toma-se, assim, a história de vida como uma unidade de análise reveladora da relação entre o social e o indivíduo. História de vida que expressa as possibilidades históricas concretas de aquela vida se constituir.[...] [E] tentar compreender o texto que emerge dessas tramas tão cotidianas reveladas na história de vida de sujeitos reais, numa tentativa de trazer o indivíduo inteiro para o diálogo da pesquisa, e de compreender este sujeito na complexidade das múltiplas determinações de seu tempo e lugar social. Indivíduo que não é constituído apenas por um aparato biológico, e sim um indivíduo que faz parte de uma sociedade, marcado por um tempo, por um lugar social. (p.44-45). 


\section{1 - Organização do estudo}

A pesquisa foi realizada no período entre março de 2008 e agosto de 2010 . Inicialmente, voltou-se aos dados já registrados sobre saúde de pessoas com deficiência, sendo feito levantamento bibliográfico e estudo deste material, incluídas as seguintes temáticas: história da atenção à saúde da pessoa com deficiência, modelos de atenção em saúde desta população, necessidades e demandas em saúde, conceitos norteadores da Saúde Coletiva para prática e assistência (cuidado e integralidade, especialmente). O objetivo desta leitura e reflexão foi produzir um diálogo do campo atenção à pessoa com deficiência e referenciais da Saúde Coletiva, a partir dos dados existentes e publicados e, além disso, segundo Gonçalves e Lisboa ${ }^{49}$ é fundamental que o pesquisador tenha um arcabouço teórico como uma "bússola" para ir a campo.

Em uma segunda etapa, foram produzidos os dados primários da pesquisa, e a técnica escolhida para isso foi a história de vida, como já mencionado, uma vez esta permite uma apreensão mais aprofundada dos modos de andar a vida dos sujeitos e do lugar efetiva ou potencialmente ocupado pela atenção à saúde.

A partir disso, deu-se uma terceira etapa, de análise dos dados obtidos, produzindo-se uma reflexão à luz dos aspectos teóricos desenvolvidos anteriormente.

Durante todo o processo da pesquisa (produção de dados, análise, redação), o retorno ao quadro teórico de referência foi inerente, sendo agregadas novas informações e reflexões, e também buscando-se outras referências complementares, para validar e enriquecer os dados obtidos em campo. Além disso, a produção de dados e sua análise também são processos dialógicos, ainda que haja predominância de um ou outro nos diferentes momentos da pesquisa. 
Foram realizadas entrevistas em profundidade, mediante autorização do entrevistado (termo de consentimento livre e esclarecido, em anexo), com seis pessoas com deficiência. Estão incluídos como sujeitos da pesquisa:

- Pessoa com deficiência física congênita;

- Pessoa com deficiência física adquirida;

- Pessoa com deficiência auditiva congênita;

- Pessoa com deficiência auditiva adquirida;

- Pessoa com deficiência visual congênita;

- Pessoa com deficiência visual adquirida.

E, utilizou-se as categorias baseadas no decreto $n^{\circ} 5.296 / 04$, no qual consta a seguinte classificação ${ }^{24}$ :

- Deficiência Física: Alteração completa ou parcial de um ou mais segmentos do corpo humano, acarretando o comprometimento da função física; excetuam-se as deformidades estéticas e as que não produzam dificuldades para o desempenho de funções;

- Deficiência Auditiva: Perda bilateral, parcial ou total, de quarenta e um decibéis ou mais, aferida por audiograma nas freqüências de $500 \mathrm{~Hz}, 1000 \mathrm{~Hz}, 2000 \mathrm{~Hz}$ e $3000 \mathrm{~Hz}$;

- Deficiência visual: Cegueira na qual a acuidade visual é igual ou menos que 0,05 no melhor olho, com correção óptica; baixa visão; campo visual em ambos ou olhos igual ou menor que $60^{\circ}$;

- Deficiência Mental: Funcionamento intelectual significativamente inferior à média, com manifestação antes dos 18 anos e limitações associadas a duas ou mais áreas de habilidades (comunicação, cuidado pessoal, habilidades sociais, utilização dos recursos da comunidade, saúde e segurança, habilidades acadêmicas, lazer e trabalho). 
Foram incluídos sujeitos com idade entre 40 e 65 anos, do sexo feminino ou masculino, todos com histórico (pregresso ou atual) de atendimento em serviços de atenção à pessoa com deficiência no SUS.

A divisão por tipos de deficiência foi definida para possibilitar a identificação de especificidades de cada um deles, e os temas comuns a todos. O critério de idade (40-65 anos) foi escolhido por facilitar que o informante tenha uma maior experiência de vida, conseguindo-se potencialmente abordar uma maior gama de aspectos da vida com deficiência; considera-se até 65 anos para que não fiquem muito demarcados aspectos voltados ao envelhecimento. A separação entre deficiência congênita e adquirida é justificada pelo fato de que são "modos de andar a vida" bastante diferentes para um sujeito que sempre teve deficiência e aquele que lidou com uma grande ruptura em sua vida. 0 critério de atendimento no SUS buscou homogeneizar nível de uso de serviços e nível social.

Com estes critérios de inclusão, buscou-se a diversificação que, segundo Gonçalves e Lisboa ${ }^{49}$, é um critério importante na amostra da pesquisa qualitativa, possibilitando abarcar o campo de investigação através de sujeitos diferentes, conhecedores e pertencentes a ele.

Foram excluídos da pesquisa aqueles sujeitos que não quiseram/puderam participar, e aqueles que não contemplaram os critérios estipulados (tipo de deficiência, faixa etária, experiência de atendimento em serviços de saúde). Não foram incluídos portadores de deficiências múltiplas (mais de um tipo de deficiência associado), por ser entendido como fator dificultador na análise do material, uma vez que busca-se identificar especificidades e similaridades entre os diferentes tipos de deficiência. Foram excluídas ainda da pesquisa as pessoas com deficiência mental, pois para que as mesmas pudessem contar sua história de vida, outros métodos seriam mais adequados, e não a entrevista somente. 
As entrevistas foram feitas mediante interesse e autorização do entrevistado, em três tomadas, com duração prevista de uma hora para cada, em local escolhido pelo sujeito. Os encontros foram gravados (permitindo o registro total do relato), sendo utilizado roteiro de questões amplo (roteiro utilizado em anexo), a fim de estimular a livre narração.

O roteiro foi construído a partir das referências teóricas que nortearam a pesquisa, e sua presença é fundamental para garantir que as questões da pesquisa apareçam no relato do entrevistado. Porém, outros itens foram inseridos nas entrevistas, a partir das novas questões que emergem nas narrativas e da reflexão constante entre campo e teoria ${ }^{48}$.

Optou-se pela realização das entrevistas em mais de um encontro para possibilitar maior reflexão e lembrança do entrevistado, e estudo do material já existente pelo pesquisador ${ }^{48}$. Além disso, o vínculo que vai sendo construído entre entrevistado e pesquisado permitiu uma relação de maior confiança e, potencialmente, a emergência de temas mais significativos para o entrevistado.

Os sujeitos da pesquisa foram captados pelo mecanismo de indicação interpessoal ${ }^{48}$, através da rede de contatos da pesquisadora, nos serviços e através de profissionais com quem atua, que indicaram os primeiros informantes, surgindo a partir daí novas indicações. A cada contato buscando indicações, era explicado o objetivo da pesquisa e os critérios de inclusão/exclusão dos sujeitos, ocorrendo a indicação a partir destes aspectos.

Como critério para indicação de novos informantes e finalização do processo foi utilizado o critério da saturação, sendo incluídos no total seis participantes (um de cada categoria). Seguindo tal critério, segundo Flick ${ }^{52}$, significa que a amostragem foi interrompida quando não foi encontrado mais nenhum dado ou conhecimento adicional para se desenvolver a análise da pesquisa. 
Além das entrevistas, também foi realizado diário de campo, no qual constam anotações detalhadas e sistemáticas sobre a entrevista, impressões do pesquisador, comportamentos do entrevistado, descrição do espaço físico da entrevista, outros comentários, reflexões, etc. Este diário de campo está em anexo a este trabalho.

De acordo com Baena e Borrego ${ }^{53}$, no diário de campo devem estar contidas as informações sobre as maneiras como se estabeleceram os contratos com os informantes, como se dá a entrevista, as impressões e os dados gerais mais importantes; devem também estar descrito o desenrolar da entrevista e os discursos que não podem ser gravados (como ambiente, gestos, olhares, linguagens não-verbais); o pesquisador deve ainda fazer uma elaboração descritivo-analítica do processo da entrevista, sua relação com o entrevistado, temas que surgem durante a conversa, interesses para a análise, assuntos para os próximos encontros, deixando clara a presença do pesquisador neste processo.

Schraiber ${ }^{48}$ ressalta ainda que com o diário de campo há a possibilidade de registrar as informações obtidas fora do momento da entrevista, nas conversas informais, nos momentos pré e pós gravação - informações estas que, muitas vezes, não são relatadas durante a entrevista gravada. Assim como o diário, o roteiro utilizado para o diário de campo também se encontra em anexo.

\section{2 - O campo da pesquisa}

A partir da aprovação do projeto de pesquisa pelo Comitê de Ética em Pesquisa da Faculdade de Medicina da Universidade de São Paulo em setembro de 2008, o desenvolvimento do trabalho de campo foi iniciado em outubro de 2008, com a realização de uma história de vida de pessoa com deficiência, um sujeito do sexo masculino que possui deficiência visual adquirida. Com o material 
e a reflexão produzidos a partir desta primeira história, optou-se em realizar uma qualificação no período inicial do campo da pesquisa, com apenas uma história de vida realizada, para que os questionamentos, as sugestões e a crítica da banca de qualificação sejam melhor incorporados no estudo, ampliando e enriquecendo a produção de dados e a análise posterior. A qualificação foi realizada no dia 18 de junho de 2009.

Foram entrevistados mais cinco sujeitos, no período entre março de 2009 e maio de 2010, todos pela própria pesquisadora. Com todos os sujeitos foram realizados três encontros, com duração média de sessenta minutos cada. Os intervalos entre os encontros para cada entrevistado variaram entre um dia e quinze dias. As entrevistas foram realizadas em locais variados, na preferência do entrevistado, como na própria residência, no serviço de saúde, ou no local de trabalho. Antes da realização dos encontros presenciais para as entrevistas, foram feitos contatos telefônicos, confirmando o interesse na participação, apresentando a pesquisa, explicando sua metodologia, orientando quanto a possíveis dúvidas.

Schraiber ${ }^{48}$ ressalta a importância de estabelecer contratos bem definidos com o entrevistado (local, objetivos da pesquisa, horário, duração, etc.) e mantê-los. O roteiro de questões foi utilizado como norteador dos encontros, e também foi elaborado diário de campo de cada encontro, redigido logo após a realização de entrevista, sendo complementado com outras observações e informações que apareceram ao longo da pesquisa.

Após a realização e gravação das entrevistas, o passo seguinte foi a transcrição completa das mesmas, realizada por outra pessoa, com experiência na transcrição de entrevistas. É importante considerar a impossibilidade de transcrições objetivamente literais do material gravado, uma vez que a linguagem oral e a linguagem escrita são sistemas paralelos de linguagem, com autonomia relativa e com estruturas específicas ${ }^{53}$. Caiado ${ }^{10}$ aponta aspectos 
fundamentais que emergem da transcrição: multiplicidade de elementos que compõem os significados na linguagem oral e constituição social dos significados revelados nas palavras. Com isso, o material gravado em áudio foi arquivado, a fim de possíveis necessidades de outras informações no decorrer da pesquisa e em outros estudos futuros.

Conforme indicado por Baena e Borrego ${ }^{53}$, foram estabelecidos critérios para a transcrição, em um esforço de busca de qualidade e fidelidade nos modos de transcrever a linguagem oral para a linguagem escrita. Expressões e palavras suprimidas, o uso de linguagem popular, os silêncios, as risadas, as palavras cortadas, os sons, os ruídos são informações importantes, que também são indicativos da dinâmica da conversação.

Com o material transcrito, foi feita uma revisão da transcrição, ouvindo-se novamente todas as entrevistas (agora pelo próprio pesquisador), verificando-se a adequação do texto e o respeito aos critérios estabelecidos. Além da transcrição das falas propriamente ditas, nesta etapa foram incluídas - assim como proposto por Caiado ${ }^{10}$ - informações complementares como movimentos corporais realizados, expressões como choro, por exemplo, interrupções por outros sujeitos, etc.

Após a transcrição literal, foi feita a edição do texto, retirando-se erros gramaticais, digressões, as falas do entrevistador, pausas e titubeações, cortes de frases ou idéias, interrupções. Caiado ${ }^{10}$ utiliza a seguinte nomenclatura para esta etapa: transcriação, isto é, partindo da transcrição literal, o pesquisador confere ao texto uma organicidade compreensível. Assim como Schraiber ${ }^{48}$ e $\mathrm{Bosi}^{46}$, para melhor interlocução com o leitor, optou-se em apresentar este material como resultado final das histórias de vida.

Nas histórias editadas, já foi incluído também o nome fictício do entrevistado, garantia de sigilo e confidencialidade da pesquisa. Este material foi enviado aos entrevistados por correio, junto com uma carta de apresentação, 
havendo abertura para a sugestão de modificações por parte dos mesmos, a fim de garantir sua fidedignidade ao sujeito da pesquisa. O material foi enviado impresso para cinco dos sujeitos, e para um deles (com deficiência visual total), foi enviado em áudio, gravado em CD. Não houve nenhuma sugestão de modificação.

Este processo final de apresentação das histórias é chamado por Caiado ${ }^{10}$ como textualização, em que a narrativa deve ser clara, coerente e deve-se certificar que o entrevistado identifique-se e reconheça seus temas e seu ritmo na narrativa. É fundamental ressaltar que, em todo este processo, não foi trocada nenhuma palavra proferida pelo entrevistado, preservando significados socialmente aceitos e sentidos marcados na vida de cada um dos sujeitos ${ }^{10}$.

É importante mencionar que nos processos de transcriação e textualização manteve-se o estilo narrativo de cada entrevistado, os modos de falar, de construir o discurso. Cada história editada tem uma "personalidade" única, daquele que a contou. Em um dos discursos especificamente, de Rubens, que tem deficiência auditiva congênita, pelas suas dificuldades de comunicação, a construção do discurso foi mais truncado, exigindo da pesquisadora/entrevistadora perguntas mais pontuais e recorrentes. Assim, mantiveram-se as falas do entrevistado, inserindo-se entre colchetes trechos de contextualização do discurso, advindos dos questionamentos e perguntas realizadas, ou de comentários da irmã do entrevistado, que participou em alguns momentos da entrevista.

Para o processo de análise propriamente dito, foi realizada uma "imersão" para análise, ou seja, foram feitas muitas leituras do material e, a cada uma delas, foram escritos comentários e identificados os trechos significativos. O estudo deste material foi feito em três níveis, buscando as palavras-chave, os temas emergentes e as tendências gerais, conforme proposto por Houltz ${ }^{51}$. 
A partir da análise, foi redigido um texto descritivo, produzindo-se um diálogo entre os núcleos temáticos identificados e os referenciais da Saúde Coletiva adotados. Também foi redigido um quadro sintético, buscando-se as "tendências gerais" a partir do material, em confluência com o tema central da pesquisa: necessidades de saúde de pessoas com deficiência.

É fundamental ressaltar que todo o estudo foi realizado de acordo com os preceitos de ética em pesquisa. Como já mencionado anteriormente, o projeto foi submetido e aprovado pelo Comitê de Ética em Pesquisa da Faculdade de Medicina da Universidade de São Paulo, sob o parecer número 0494/08, que se encontra em anexo. No primeiro encontro com cada entrevistado, foi entregue o Termo de Consentimento Livre e Esclarecido (também em anexo), sendo lido conjuntamente, assegurando-se o compromisso de sigilo de sua identidade.

\section{3 - As histórias}

As histórias editadas e finalizadas estão disponibilizadas em anexo. Para cada história, foi dado um título, com algum trecho significativo da entrevista ou a partir do sentido geral da narrativa. Aqui serão apresentadas as informações gerais dos sujeitos da pesquisa, na ordem de realização das entrevistas, já com os nomes fictícios.

\section{1) "Sem enxergar, não adianta sonhar..." - A história do Sr. Jair}

Sr. Jair é um aposentado de 62 anos, portador de deficiência visual adquirida (glaucoma) há aproximadamente 08 anos e morador do distrito Raposo Tavares, localizado na região oeste da cidade de São Paulo. Foi indicado como informante por uma terapeuta ocupacional que atua na Unidade Básica de Saúde do bairro; depois da profissional ter confirmado o interesse do Sr. Jair em participar da 
pesquisa, foi feito contato telefônico explicando a pesquisa e agendamentos. Sr.Jair é casado, mora com a esposa, o filho e o neto; trabalhava como porteiro. Foram realizados três encontros, com duração média de uma hora e quinze minutos de gravação em cada um deles, todos na casa do entrevistado. 0 intervalo entre as entrevistas foi de oito dias, no mês de outubro de 2008 $(06 / 10 / 2008,13 / 10 / 2008$ e 20/10/2008).

\section{2) "Eu quero viver..." - A história de Ricardo}

Operador de telemarketing de 42 anos, portador de deficiência física congênita (paralisia infantil), Ricardo é militante do movimento social das pessoas com deficiência. Morador da região do Jaguaré, zona oeste da cidade de São Paulo. Foi indicado como informante por uma terapeuta ocupacional que atua na Unidade Básica de Saúde do bairro (a mesma que indicou o Sr.Jair). É solteiro e mora sozinho.

Os três encontros realizados tiveram duração média de uma hora. Dois foram realizados no local de trabalho de Ricardo, no bairro da Lapa em São Paulo (cada um deles com trinta minutos de duração) e um encontro foi feito na casa do entrevistado (este com duração de duas horas). O intervalo entre as entrevistas foi pequeno, variando entre um dia e três dias, no mês de março de 2010 (27/03/2009, 28/03/2009 e 31/03/2009).

\section{3) A história de Cristina - Sacrifício e fé...}

Técnica de enfermagem de 45 anos, Cristina é portadora de deficiência auditiva adquirida (otosclerose); percebeu os primeiros sinais da doença na adolescência. Fez cirurgias, hoje utiliza aparelho auditivo em um dos ouvidos. É moradora da região de Perdizes, na cidade de São Paulo, trabalha em unidade básica de saúde da região do Butantã, na mesma cidade. Foi indicada por uma médica 
desta unidade. Mora com sua mãe idosa da qual é cuidadora, pois a mesma tem Doença de Alzheimer.

Os três encontros foram realizados na UBS em que Cristina trabalha, com duração média de cinqüenta minutos cada. O intervalo entre as entrevistas variou entre oito dias e quatorze dias, todos em junho de 2009. (01/06/2009, 08/06/2009 e 22/06/2009).

4) "Tudo começa pela gente..." - A história de Ângela

Com 47 anos, Ângela tem um filho e atualmente não trabalha. Portadora de deficiência física adquirida há cerca de três anos, devido adoecimento por Esclerose Múltipla, mora na zona sul da cidade de São Paulo. Foi indicada para a entrevista pela enfermeira do serviço de reabilitação que freqüenta. É separada, vive em uma casa que tem quintal comum com outras irmãs, que a ajudam no cotidiano.

Os três encontros foram realizados no serviço de reabilitação, em um horário vago entre as consultas, com duração média de cinqüenta minutos cada, nos meses de junho e julho de 2010. O intervalo entre as entrevistas foi de duas semanas (19/06/2009, 03/07/2009 e 17/07/2009).

5) "Não é fácil, mas também não é difícil se você quiser..." - A história de Fátima

Mulher de 55 anos, Fátima nasceu no interior do Nordeste, vindo para o estado de São Paulo já adulta, buscando tratamento, pois tem deficiência visual congênita. Moradora da cidade de Santos, no litoral de São Paulo, foi indicada pela assistente social da instituição que freqüenta.

Os três encontros foram realizados nesta instituição, no final do dia, com duração média de quarenta e cinco minutos cada. O intervalo entre as 
entrevistas foi de uma semana, nos meses de março e abril de 2010 (22/03/2010, 29/03/2010 e 05/04/2010).

6) A história de Rubens - O pedreiro sonhador

Com 54 anos, Rubens nasceu no Paraná e veio para São Paulo quando criança. Tem muitos irmãos, trabalhou como pedreiro e serviços gerais. Tem deficiência auditiva congênita, buscando serviço de saúde específico em 2010, pois deseja o aparelho auditivo par retomar o trabalho (interrompido pela dificuldade de comunicação). Morador da zona oeste da cidade de São Paulo (região do Butantã), foi indicado através do médico otorrino que o atendeu. Mora sozinho e seus irmãos moram na mesma rua. Sua principal referência é a irmã Rosa, que o auxilia no cotidiano e o acompanha em consultas e atividades sociais.

O primeiro encontro foi realizado na clínica, e os outros dois foram realizados na casa de sua irmã Rosa. O intervalo entre as entrevistas foi de uma semana, no mês de maio de 2010 (14/05/2010, 21/05/2010 e 28/05/2010). 


\section{A partir dos relatos...}

A partir das histórias de vida, foi possível elencar diversos aspectos da vida da pessoa com deficiência e sua relação com o contexto da assistência em saúde. Como forma de organizar a discussão, propõe-se cinco grandes temas ligados às necessidades da pessoa com deficiência, construídos na análise da pesquisa:

- A vivência da deficiência

- Independência, autonomia e apoio

- Acesso e direitos

- Sentidos das intervenções

- Ações e estratégias

Há assuntos abordados em mais de um tema; a divisão é didática, a fim de facilitar a análise e o encadeamento das idéias, bem como a compreensão do leitor.

\section{1 - A vivência da deficiência}

A deficiência constitui a identidade do sujeito; há aspectos distintos entre aqueles que nasceram com a deficiência e aqueles que a adquiriram ao longo da vida, e estas diferenças são questões fundamentais na construção da identidade e da subjetividade do sujeito. Segundo Pereira ${ }^{9}$, a identidade do sujeito se constitui de maneira relacional, e para as pessoas com deficiência, relação determinada pela marca da diferença e da exclusão.

Fica explícito que, no caso de deficiências adquiridas, há uma ruptura na vida subjetiva e cotidiana do sujeito; Cristina utiliza o termo "lutas silenciosas", 
para definir o processo que enfrenta cotidianamente, mas entende que também os "perfeitos" têm suas lutas. Para as deficiências congênitas, a vida se constitui a partir das possibilidades e incapacidades dadas a priori, em outros modos de apreensão do mundo subjetivo, relacional e cotidiano. É preciso considerar também que outras características farão parte deste processo: história de vida, organização familiar, rede social, aspectos culturais, aspectos financeiros, valores, entre outros.

Nas palavras de Bosi"46: "Cada imagem formada em mim está medida pela imagem, sempre presente do meu corpo" (p.44); com as mais diferentes diversidades funcionais, constroem-se inúmeras imagens do mundo e de si próprio: uma imagem formada por vários elementos sensório-motores, a partir de cada um destes sujeitos, e de cada uma de suas vivências a partir das deficiências. É da distinção entre o corpo que nasce "perfeito" e adquire a deficiência ao longo da vida, e aquele que se constitui a partir da deficiência que estamos falando.

"Eu acho que é difícil você nascer surdo e não ouvir, mas quem ouve e depois vai perdendo... Esse contato é ruim..." [Cristina]

"[...] Porque eu já vim de criança, então minhas oportunidades foram diferentes do que aquele cara que já tinha uma, uma vida de motoboy ou sei lá, mas caiu e se acidentou, ou tinha o seu carro, bateu e não seu quê, e ficou paraplégico... Mas aí já tinha suporte, tinha uma vida, um trabalho..." [Ricardo]

Segundo Pereira ${ }^{9}$, há uma dimensão fundamental a ser considerada ainda: a intensa diferença entre as pessoas com deficiência. Ainda que o estigma coloque todos em condição de igual (e total) limitação, são muitas as formas de (com)viver com a deficiência. 
Para o Sr. Jair, Cristina e Ângela, a ruptura é presença constante no discurso. E, o momento do diagnóstico é relatado como algo repentino, e que traz uma mudança muito grande na vida e no cotidiano destas pessoas. Segundo Bosi $^{46}$, a sucessão de etapas da memória é divida por marcos, pontos nos quais a significação da vida se concentra, como mudanças, mortes, celebrações, etc. Percebe-se o quanto a deficiência é um marco intenso na vida destes sujeitos, um marco de mudanças completas e radicais no seu modo de viver e de estar no mundo. Há outros marcos importantes também relatados, que estão para além da deficiência: a perda do emprego para Cristina, o nascimento de seu filho para Ângela.

Para os sujeitos com deficiência congênita (Ricardo, Fátima e Rubens), a apreensão e a compreensão do mundo aconteceram de maneiras diversas, considerando-se as deficiências e incapacidades apresentadas por cada um deles. Para Fátima, aquelas pessoas que nasceram com deficiência visual tem mais segurança no enfrentamento das situações cotidianas, pois não há a ruptura causada pela deficiência adquirida ao longo da vida e a perda das referências sensório-motoras.

"Tem grande diferença [entre deficiência congênita e adquirida]. Principalmente para aqueles cegos que não viram antes, eles tem mais segurança em tudo... [...] Então tem grande diferença pra quem já teve e pra quem nunca teve [visão]... Porque quem nunca teve, ele nunca viu, ele não tem medo de obstáculo. Ele caiu, mas ele fala assim: 'Ah! Eu nunca vi mesmo, eu caí, mas eu vou levantar!'. Mas quem já viu... Se eu disser assim: 'Ah, cuidado! Que ali tem um carro!'. Pronto! Ele empaca ali e ninguém tira.". [Fátima]

Houltz $^{51}$ refere que a maneira como o sujeito conta e a ordem em que os assuntos emergem retratam a importância dada a determinadas questões. A história da deficiência e as limitações dela advindas aparecem já no início dos 
relatos, retornando constantemente às falas, demonstrando a relevância desta em sua história pessoal. No caso de Rubens, por exemplo, mesmo com a grande dificuldade de comunicação imposta pela sua deficiência auditiva, é sobre a história de seu problema que ele inicia o relato.

Emerge o tempo vivido da memória, ou seja, o registro que está para além da ordem cronológica dos fatos, mas pautados pela experiência vivida (tempo complexo e repleto de rupturas e conflitos). Aparecem as diferentes formas de lidar com a deficiência, as diferentes oportunidades vivenciadas, surgem diferentes sentidos para as vivências, encontros e - inclusive - tratamentos e aspectos ligados à área da saúde.

O diagnóstico de uma doença irreversível, que traz deficiências e incapacidades é, muitas vezes, algo que o sujeito desconhece. O glaucoma, a esclerose múltipla, ou a síndrome pós-polio, são doenças sobre as quais o paciente buscará informações para saber melhor. Para o Sr.Jair, há a necessidade de mais campanhas informativas e que, agora, quando há campanhas, ele indica a todos os familiares e colegas. A projeção de pessoas com deficiência na mídia também foi relatado como algo que divulga a existência destas doenças e dos modos de viver destas pessoas, podendo minimizar o preconceito e a discriminação.

Para Ângela, a fonte de informação foi a internet, na qual obteve informações acerca da doença, prognóstico e tratamento, com ajuda da família. Ainda que alguns profissionais que a atenderam não a incentivam nesta atitude, ela relata que informação é muito importante e foi significativo para ela. Há um imaginário que afirma ser melhor para o paciente ele não saber sobre sua condição, ainda mais em casos de doenças graves com prognóstico ruim, e é possível relacioná-lo ao posicionamento destes profissionais.

Fátima, por exemplo, conta que o médico preferiu conversar primeiro com os irmãos, separadamente, informando-os que sua doença ocular estava 
avançadíssima, e seria preciso fazer uma cirurgia para retirada dos dois globos oculares. É ela quem chama o médico para lhe contar a verdade sobre sua situação de vida, prognóstico e possibilidades.

"Ele chamou o meu irmão e a minha cunhada que foi comigo, pra uma sala, me deixou lá... Daí falou que não tinha jeito... Só que eu também, quando eu saí da casa do meu pai, eu já imaginei que eu tirar as minhas vistas... Ele tornou a voltar, eu perguntei: 'Doutor, você vai tirar as minhas vista?'. Ele falou: 'Não filha, calma!'. Daí eu falei: 'Não, doutor, não precisa me enganar porque eu já sei. As minhas vistas não tem mais solução'. Ele perguntou como é que foi, eu falei tudo, contei a história..." [Fátima].

Para o sujeito, ficam as perguntas: Quem sou eu agora? O que é esta doença que faz parte de mim? Como vivencio meu cotidiano com algumas limitações? E, dentro do contexto da deficiência, a irreversibilidade é um aspecto de fundamental importância, pois como disse Ângela à sua irmã:

"Eu não tô doente, eu tenho uma doença... É diferente... Eu não tô doente... Eu não tô com resfriado... Eu não estou com uma dor de barriga que vai passar daqui a pouco... Não é isso...". [Ângela].

Para o Sr. Jair, sua reação diante da aquisição da deficiência é um grande "trauma" (em suas palavras), e durante seu relato, fica claro como todo este processo foi muito marcante para ele, pois retoma várias e várias vezes a esperança em enxergar e a necessidade de se conformar com as limitações irreversíveis.

"As pessoas com deficiência que eu conheço ainda tem muito trauma. A deficiência traz uma trauma pra pessoa. Eu sinto isso sim, mas traz mesmo pô. Só a ansiedade de eu querer, de eu estar conversando com uma pessoa e de querer enxergar, aquilo já é um trauma que sempre a pessoa vai carregar. Aquela ansiedade de ver a pessoa, 
entende... Porque é sempre um trauma, é a mesmo coisa quem tem acidente na mão, e ao pegar em algum objeto não pega, tem sacrifício pra pegar nas coisas, porque a mão falta dois, três dedo. Tem diferença... Até pra escrever, às vezes vai aprender a escrever com a esquerda. Tudo isso a pessoa tem trauma, dificuldade..." [Sr. Jair]

Em outros trechos, ele se utiliza de expressões muito fortes, que trazem a conotação do grande sofrimento vivido com a ruptura existencial e cotidiana que é adquirir uma deficiência e ter que se deparar com um mundo novo, de limitações, de tratamentos e de profissionais pouco interessados no seu sofrimento e em sua história: "comi grama ali, principalmente no começo", "comi o pão que o diabo amassou", "sofri muito", "[no tratamento é] então você que se dane", "[ter a deficiência] é o mesmo que levar uma facada", "[ter a deficiência] é o mesmo que levar um tiro".

Como já mencionado, com a ruptura da deficiência adquirida, a rotina se transforma; o termo "rotina normal" é utilizado para identificar a rotina prévia à deficiência. Nos casos de deficiência congênita, o termo "normal" é usado como o ideal atingido (ou a ser atingido). Junto com esta idéia, está vinculado o status de "anormal" à deficiência. A idéia de normalidade (e, portanto, de anormalidade) pressupõe a existência de um padrão adotado como referência, como ideal, e só tem sentido se algo existir fora dela - isto é, a norma estabelece-se pela ocorrência de sua infração ${ }^{9}$.

Em consonância o referencial da "normalidade" está o modelo médico, ainda predominante nas concepções e práticas que envolvem pessoas com deficiência, trazendo consigo um ideal de retorno à normalidade (e, portanto, reversão de uma condição potencialmente irreversível) como objetivo final da assistência à saúde das pessoas com deficiência. No discurso de Ângela, é nítida a valorização da vida "normal" antes da deficiência: 


\begin{abstract}
"Mas, antes era melhor. Eu trabalhava, passeava com meu filho, com meus sobrinhos. Nossa, parece ser uma outra pessoa. Parece quando muda de casa, mudou de lugar, tudo diferente... É a mesma casa, mas tudo ficou diferente... E teve coisa que mudou na casa também: o telefone mudou de lugar, no banheiro já fizemos uma outra adaptação. Então, quer dizer que mudou, alguma coisa acabou mudando. Pano de chão quase já não tem mais, por que eu tropeço nele. Outras coisas... [A vida antes] Era normal; era bem corrida, mas era normal... [...] Olha, é uma mudança horrível, parece que é um outro mundo. Tem horas que eu penso assim: Nossa, parece outra Ângela, nem parece eu..." [Ângela].
\end{abstract}

Deve-se apontar para o fato de que os entrevistados com deficiência adquirida têm um relato de algum colega ou alguma história de alguém que se "curou" da deficiência e retornou à normalidade, contribuindo para este imaginário. O retorno à funcionalidade é almejável e desejável, para o nível máximo possível, mas, mesmo em condições que o retorno à funcionalidade seja possível, a "normalidade" é somente um ideal. Após as experiências vividas, o sujeito torna-se diferente.

Em um exemplo bastante concreto, o Sr. Jair conta como foi quando sofreu uma queimadura na mão: com fisioterapia conseguiu retornar ao trabalho e à independência nas atividades de vida diária, mas indica que ainda hoje, mais de vinte anos depois, a sensibilidade da mão é diferente.

Mesmo sendo possível prevenir/minimizar incapacidades, fica o desafio do como lidar com a irreversibilidade. Ainda que, especialmente nos últimos anos, os avanços no campo da Medicina, da Genética e da Biologia sejam consideráveis, a condição atual para as pessoas é de irreversibilidade da deficiência. Nos aspectos relacionados às incapacidades e desvantagens há mais recursos de adaptação, mas mesmo estes, estão ainda distantes, especialmente em um contexto como o Brasil. 
"Eu já me conformei... Antes eu não me conformava não, eu não me conformava que eu não ia enxergar. Te juro mesmo, eu falava: Não é possível... Pra que tem essas porcaria de médico? Aí eu encontrava outros pacientes que ficavam: Eu operei o meu, eu num enxergava nada... Mas era outra doença, agora essa glaucoma acho que é a pior que existe. Eu já vi colega meu cego, que não enxergava daqui a um palmo, aí operou e voltou a enxergar. Mas o glaucoma nunca ouvi falar, quando perde, perde mesmo. [...] Eu não me conformava quando o médico falava assim que eu não ia enxergar, que eu não ia voltar a enxergar. Então por que que eu sofro tanto assim? Com esses tratamentos, essas cirurgia que estão fazendo aí. Pra que fazer essas cirurgia? Se eu não vou voltar a enxergar... Eu ficava inconformado, ficava nervoso e ao mesmo tempo doido pra ele terminar..." [Sr. Jair].

Outro ponto a ser considerado na vivência da deficiência, é a ameaça da piora, uma vez que as doenças degenerativas podem evoluir. São dois aspectos intensamente presentes no cotidiano das pessoas com deficiência, parecendo ser importante haver espaço para sua elaboração e enfrentamento.

"Eu não tenho mais futuro não... Eu só não quero piorar... Só penso nisso! Se eu envelhecer assim, tá ótimo, tá muito bom. Só tenho medo da piora... Quando as mãos começarem a ficar fracas, tenho medo..." [Ângela].

"Em casa, eu não fico usando muito o aparelho porque quero forçar eu ouvir melhor. Mas não adianta, é uma coisa que tá lá... Aí eu vejo que quando eu boto o aparelho, eu ouço sons que eu não ouço sem... E aí você... [pausa, choro] É custoso falar... E aí você tem que ir lidando e, às vezes, parece que não está ficando bom... Eu penso só na possibilidade de ficar surda... Eu tenho medo, meu pai morreu surdo... É ruim pra mim..." [Cristina].

"Aí me assustei lá, fiz todos os exames lá, a coisa não tava tão avançada em mim, porque eu tinha trinta e cinco 
anos. Agora eu tenho quarenta, e aí eu resolvi esquecer um pouco disso lá. Se eu vou ter síndrome pós-pólio, vou, já sei disso, deixa isso pra lá. Agora, ficar muito encanado lá, indo lá na UNIFESP pra ver os outros pacientes que... os pacientes já tão com balão de oxigênio, porque os músculos não conseguem puxar mais ar. Eu sei que eu vou chegar nisso. Então não quero ter, um contato com isso agora. Antes do tempo... Isso que me preocupa, me preocupa muito. Quero ter, procuro ter minha vida independente, e dependo sim de um monte de gente, acho como todo mundo depende... Eu mais um pouquinho mais..." [Ricardo].

A ameaça de piora e/ou a irreversibilidade podem ficar como uma sombra na vida do sujeito, sendo difícil fazer planos para o futuro; nas entrevistas, é com dificuldade que alguns sujeitos contam seus projetos ou o que pensam sobre o futuro. Choro, pausas, dificuldade em explicitar e nomear projetos foram algumas das reações observadas, retomando-se o assunto em diversos trechos de cada entrevista. Medo é uma palavra utilizada de maneira recorrente.

É, portanto, uma gama de sentimentos e emoções que a deficiência produz no sujeito. A experiência é única e pessoal, mas diversos fatores influenciarão este momento, como descritos por Wash ${ }^{54}$ : se é congênita ou adquirida, tipo de instalação da deficiência (doença, acidente, violência, etc.), estágio da vida em que o sujeito está, quais áreas de funcionalidade serão prejudicadas, grau de severidade da deficiência, prognóstico, "visibilidade" (o quanto a deficiência ou deformidades são visíveis para as outras pessoas), dor, características individuais (sexo, idade, história de vida, interesses e objetivos, personalidade), além do contexto social em que o sujeito está imerso e sua permeabilidade à diferença.

Além do medo, outros sentimentos relatados pelos entrevistados foram: raiva, angústia, vergonha, nervosismo, inconformismo, tristeza, desamparo, cansaço. Pode também mobilizar aqueles que estão ao seu redor, familiares, 
amigos, comunidade; são descritos reações como: superproteção, dó, isolamento, estranhamento, segregação, decepção. Acostumar-se, adaptar-se, suportar, não perder a esperança, aprender a conviver são alguns dos nomes dados pelos entrevistados a estes mecanismos de enfrentamento, que se relacionam intrinsecamente a história de cada um, e a seusrecursos internos e externos.

A adolescência e a infância com deficiência são momentos bastantes específicos, que trazem experiências para o sujeito no processo de enfrentamento da deficiência e das limitações. Para Ricardo, ter uma deficiência o impulsionou a amadurecer mais cedo, como forma de lidar com suas incapacidades. A deficiência congênita imprime características específicas nas diferentes fases da vida; Ricardo também faz uso da noção de trauma para explicar a infância e a juventude.

"Foi meio traumatizante... Eu acho que não foi nem da adolescência, porque na adolescência eu já tinha até uma aceitação, agora na infância não... Não tinha muita aceitação de fora e tinha uma coisa minha também, que eu via muita barreira. Não podia brincar como os outros, aprontar como os outros, não podia, tinha limitações. Então isso me deixava frustrado, eu tive essa crise de adolescência muito mais cedo, acho. Tive que amadurecer muito mais rápido, acho que a própria vida me impulsionou a isso." [Ricardo].

Para Fátima e Rubens, superproteção, isolamento, preconceito são a tônica do discurso:

"Eu não tive infância... A minha infância foi muito triste. Como a gente morava no norte, e o pessoal lá - para essas pessoas que têm deficiência, seja qual for - são muito cautelosos, eles não deixam... [...] A única infância, que eu me lembro, é que eu brincava com as minhas primas, eu corria, mesmo sem enxergar. Mas a minha 
mãe pegava muito no meu pé. Quanto tava só a minha mãe - meu pai trabalhava muito - ela ainda deixava eu brincar um pouquinho, mas quando o meu pai tava, eu não tinha liberdade, porque ele me prendia demais. Era só dentro de casa... [...] Depois elas [colegas] foram namorando muito cedo e aí foram me esquecendo. E eu, como não tinha namorado, fiquei brincando de boneca até quase quatorze anos sozinha. Porque eu não tinha pra onde sair. Eu não tinha namorado. Então eu fiquei, depois eu enjoei das bonecas e não brinquei mais. Foi acabando a infância... [...] A adolescência também, não foi muito boa... A adolescência foi pior ainda porque, já com dezoito anos, não tinha ninguém pra sair, ninguém queria andar comigo... A não ser as minhas tias. A minha mãe pouco saía e, outras pessoas assim, não andavam comigo porque... Na realidade, a deficiência no Norte, nesses lugares dos interiores, qualquer tipo de deficiência... Hoje até que está melhor, mas nem tanto... Mas ainda tem lugares pro interiorzão, que o deficiente é um tropeço na vida da família, dos irmãos, do pai, da mãe... Então eu era muito presa dentro de casa..." [Fátima].

"[De criança] Eu brincava de carrinho, de fazer feira... Lá no Paraná eu não tinha [amigos] não, [brincava] com os irmãos. Estudei [até] seis anos, aqui em São Paulo, no Butantã. Mas, não passei da primeira [série], me mandaram embora... [...] [Depois] Trabalhei de pedreiro, desde uns quatorze anos. [...] Eu não tenho coisa pra falar... [Quando] Criança, eu morava no barraco lá, eu gostava de pipa. Tinha sete [anos], oito, nove... Eu fazia [a pipa], mas não subia, ficava torto. Eu não [sabia] fazer pipa naquela época, agora eu sei fazer... Era peixinho... Eu tinha [amigos], mas não dava não... Era ruim, onde eu morava não dava não. [Eles faziam] ruindade..." [Rubens].

A deficiência imprime marcas concretas na vida das pessoas. O cotidiano se organiza de maneira diferente: ritmo da realização das atividades, a quantidade de tarefas realizadas, o espaço da casa, as sutilezas (como não ouvir os sons da natureza, por exemplo, como relatado por Cristina), a circulação pela cidade, a comunicação. Porém, junto com a noção de "normalidade" trabalhada anteriormente, pode ficar arraigada a idéia de um cotidiano "melhor" sem a 
deficiência, sem conjunção com uma idéia de diversidade. A vontade, o desejo, o acreditar em si próprio, a motivação e a satisfação contribuem para a vivência deste dia-a-dia, sendo preciso considerar este aspecto nas intervenções.

Para Ricardo, por exemplo, o tempo despendido para se organizar para ir ao trabalho é grande, as tarefas são sistematizadas. Fátima menciona o andar na rua com vento e chuva, e o quanto é difícil se organizar também na sua casa nestes dias. Na história de Rubens, aflora a questão da comunicação, e as dificuldades de interagir mesmo nos momentos mais simples do cotidiano (e até mesmo na própria entrevista).

Na história do Sr.Jair, surge um aspecto que merece notadamente maior discussão: a deficiência trouxe uma perda no sentido que as atividades têm para ele. Não há mais o jogo de futebol e o bar com os amigos. Os passeios e viagens - tão sonhados para o momento da aposentadoria - são projetos por ele descartados, devido à cegueira. Ir à praia, ir às festas da família, voltar à terra natal - apesar de também terem diminuído no dia a dia - fazem parte de sua vida, mas não são valorizadas. A vaidade e o cuidado com a aparência, antes tão valorizados por ele, perde espaço no seu cotidiano. É preciso confiar na esposa e na fala dos colegas para saber se a roupa combina, se o cabelo está penteado adequadamente. Ou seja, todas aquelas situações e atividades que Ihe eram mais significativas, perdem seu sentido com a deficiência visual. Ser alegre, bater papo com os amigos, e até mesmo sonhar parecem ser incompatíveis com a deficiência.

"De antes para agora, mudou muito, muita coisa. Andava mais alegre, mais contente. Em primeiro lugar, não precisava de ninguém. Eu quando queria resolver as coisas, eu ia sozinho e resolvia. Gostava muito de festa, de passear, futebol e tudo isso aí sumiu da minha vida. Não tem um lugar mais, nem a televisão, não vejo mais nada, então... Só o meu companheiro é o radinho, dorme 
comigo ligado, a mulher que briga porque eu ligo o radinho e fico. É chato, não é fácil em ter que se conformar, mas eu vou fazer o quê? Eu só rezo... Minha função é ouvir meu radinho e rezar..." [Sr.Jair].

Ele fica paralisado nesta ambigüidade, atrelando a total cegueira à total incapacidade. A carga negativa da deficiência invade o modo de estar e vivenciar seu cotidiano e contexto familiar/social. Precisar de ajuda e ter um outro ritmo para executar as atividades criam situações de desconforto para ele, na convivência com seus familiares e na sua comunidade. Com isso, acaba preferindo ficar em casa, restringindo sua circulação no meio social. Usar óculos escuros, além de proteger a vista contra a claridade e trazer mais conforto, também é uma estratégia de esconder os olhos e minimizar a visibilidade da deficiência.

No outro pólo desta discussão, está a história de Fátima, que evidencia em seu discurso a relação entre medo, coragem e deficiência. Ela traz a relação entre a ruptura e a maior carga de medo e dificuldade de enfrentamento das situações impostas no viver, identificando-se como alguém que conseguiu enfrentar muitas batalhas (especialmente pelo fato de ter ido morar sozinha); porém, aponta o quanto o medo é parte de seu cotidiano.

"O medo existe mesmo porque aqui, acolá, a gente
encontra pessoas maldosas e o medo é esse! Eu já
encontrei com pessoas maldosas. Eu já encontrei com
estrupadores, e foi terrível... Outras pessoas enganam a
gente, dizendo que é um ônibus e não é, é ônibus
errado... Outras pessoas, você pede ajuda e não ajudam...
Então as pessoas tem medo de sair. Só que se você não
sair, você não vai ver o mundo lá fora da sua maneira,
você vai ficar sempre com medo... [...] Eu me sinto mais
orgulhosa, nesse ponto... Porque dei um pulo na minha
vida, onde muitos não têm coragem... Porque para o
deficiente morar sozinho tem que ter coragem... Não é
todo mundo que consegue morar sozinho! Porque chega 
muita coisa que apavora. Chega o medo... Você começa a pensar: 'Se eu adoecer, quem vai cuidar de mim? Se acontecer de alguém entrar aqui e eu não ver, por quem eu vou chamar?'. Então se passam muitas coisas pela cabeça, se você não for uma pessoa forte, você não mora sozinha. Acho que é vontade de viver..." [Fátima].

O imaginário da deficiência como uma "tragédia pessoal"15 ainda é muito forte e presente. Ribas ${ }^{17}$ complementa esta idéia, afirmando que o sentimento de "melhor então não viver assim" continua sendo difundido socialmente, como se a deficiência tornasse a vida sem significado, chegando ao ponto da renúncia de viver. Há um estigma associado à deficiência, isto é, uma marca negativa e depreciativa que é atribuída à pessoa na sua relação com os outros; uma marca indelével que termina por reduzir a pessoa ao atributo negativo, conforme definido por Goffman ${ }^{55}$. Para Pereira ${ }^{9}$, a freqüente justificativa de uma ação com um "mas", ou um "apesar de", mostra a idéia da deficiência como um veredicto irretocável de incapacidade, ou seja, tomada como mais abrangente no corpo e na vida do que a relacionada com a real limitação existente.

Ricardo conta como é comum ouvir um "mas" na relação das pessoas com sua deficiência:

"Dizia: Ah que bunitinho, tal..., quando eu era mais novo as meninas. Ah, mas pena que usa cadeira.... Já escutei assim um comentário. Já, mas é fofinho, mas poxa não dá pra sair, não dá pra fazer nada. Então escutei isso... Escutei pessoas que chamam de inválidos. E aí eu preciso lidar muito bem com isso também, até hoje não lido muito bem, não consigo digerir isso... Eu fico até meio agressivo..." [Ricardo].

Porém, mesmo diante de tantos aspectos difíceis abordados no encontro para a pesquisa, é interessante notar como, ao longo das entrevistas, os projetos de futuro apareceram: novas atividades para aprender, encontrar (ou 
melhor, construir) novos significados para a vida, estabelecer nexos de sentido junto às pessoas queridas.

\begin{abstract}
"Eu não sei [do futuro]. [Quero voltar a trabalhar] de pedreiro, mas não tem... Ah, e ganhar [na mega sena]. Eu jogo um pouquinho, mas não acerto. Eu já acertei a quadra, outro dia. [Dá um] pouquinho [de dinheiro], às vezes, depende... [...] [Se] Eu ganhar na mega sena eu vou mudar, vou embora daqui... Vou comprar um terreno, vou comprar um sítio e virar fazendeiro... [Vai ter] vaca, vai ter manga, mexerica, laranja..." [Rubens].
\end{abstract}

\title{
5.1.1 - Nas relações...
}

A vivência da deficiência extrapola as experiências pessoais e familiares, de âmbito privado: os amigos, os espaços públicos, o contato com outras pessoas no âmbito social pertencem a este panorama. O principal tema que desponta neste aspecto das pessoas e relações é o preconceito.

"Eu acho que toda deficiência... É uma visão pessimista, mas acho que toda deficiência, de alguma forma ou de outra, ela te isola. Eu percebo nas coisas bobas, quando as pessoas estão conversando, falam muito rápido; às vezes as pessoas não repetem, porque não tão com vontade de repetir. [...] Mas eu acho que a gente é meio segregado. É o mundo das pessoas surdas, é um outro mundo; existe esse mundo, ele é vivo, tudo... Mas é um mundo ali..." [Cristina].

"Após a gravação, juntos nós vemos o livro de charges trazido por ele. São diversas situações de preconceito enfrentadas pelas pessoas com deficiência. Ricardo aponta algumas experiências que passou:

- Taxista não aceitá-lo, pois não cabia a cadeira de rodas no carro;

- Situações envolvendo sexualidade da pessoa com deficiência: "Um cadeirante pode fazer sexo?", "Uma 
pessoa sem deficiência não deve namorar uma pessoa com deficiência, pode estar abusando, é 'tarado'";

Obstáculos que impedem a circulação por espaços públicos e privados: escadas, degraus, buracos;

- Pessoa com deficiência vai pedir uma informação a alguém, que não a ouve, e Ihe dá uma esmola." [Trechos do diário de campo].

"Se é um órgão público, é o pior. Olham pra gente como se estivesse despida, parece que vai comer a gente com os olhos. Mede a bengala de cima em baixo, parece que nunca viu gente de bengala. No começo, eu achava: Meu Deus, nossa... Agora nem percebo mais, já me acostumei tanto, se estão olhando ou não. Mas olham, estranham... [...] Eu acho que, mesmo quem não tem deficiência, eles deviam olhar com mais cuidado pra a gente, ou com menos preconceito. Não sei, alguma coisa que ajudasse esse pessoal... Porque tem gente que olha pra gente assim, que a gente acaba até se sentindo mal. Parar de olhar as pessoas com tanto olhar de coitadinho, isso daí aborrece a gente... A gente adora quando alguém ajuda a atravessar uma rua, mas sem aquela coisa de... Isso vem da pessoa, ou a própria sociedade faz isso com a pessoa, deixa todo mundo assim... Não ter dó!" [Ângela]

"Agora na rua, de vez em quando você encontra preconceito. De vez em quando... O pessoal ainda não se acostumou... A sociedade ainda não se acostumou com os deficientes visuais... [...] Eu acho que ainda a sociedade precisa aprender a trabalhar mais e mais com o deficiente. De tipo qualquer, tanto o visual quanto o paraplégico. E a gente ainda tem muita dificuldade na rua" [Fátima].

Cristina fala sobre o preconceito em relação às pessoas com deficiência usando uma comparação com os animais, companheiros fiéis do seu cotidiano, que tem - para ela - importante significado. Decepção, segregação, defeito são algumas das expressões que utiliza para explicar a relação das pessoas com os animais com deficiência. Abaixo segue a história relatada por Cristina sobre uma buldogue surda, e que, portanto, tem a mesma deficiência que ela, sendo possível fazer um paralelo entre a história relatada e a sua própria. 
"... E ontem, foi de uma cachorrinha, uma buldogue, coisa mais linda, cinco meses; e ela não atendia as coisas e achavam que a buldogue era rebelde, falava pra ela fazer, ela não fazia. Ela era surda! Eu acho que eu já sei, eu vi, eu falei: Mãe, essa cachorra é surda... Ela não ouve as pessoas chamarem... Ele fez os testes lá com fonoaudiólogos, com apitos, tudo... Ela ficava do mesmo jeitinho, a orelhinha não baixava, era surda. Eu vi que a moça ficou meio decepcionada com a cachorra. Ele falou assim: Às vezes as deficiências... Eu achei legal o que ele falou. Você pode se comunicar muito mais do que se ela fosse normal.. Ele ensinou ela com luzes e ela aprendeu direitinho; aquilo que não podia era luz branca, aquilo que podia era luz vermelha, e quando ia brincar assim e ela vinha, com o comprimento da mão. Uma coisinha mais linda! Ele fez algumas coisas de sinal com ela, mas tem que ter muito mais pra chamar a atenção dela. Ela vive no mundo dela. Eu falei: É isso, a gente vive meio segregado assim..." [Cristina].

É interessante apontar que, ao final desta história, aparece o potencial e as possibilidades de comunicação da cachorra, que pode - segundo ela - ser até maior do que se ela não tivesse deficiência. Sacks ${ }^{56}$ trabalha com a idéia de que há um paradoxo da doença, pois deficiências e distúrbios podem revelar novos processos criativos, que não seriam desenvolvidos na ausência da limitação. Cristina coloca, ao final de sua entrevista, que as pessoas com deficiência precisam desenvolver seu potencial, e esta idéia também é trabalhada como forma de lidar com o preconceito e a segregação ou, em suas palavras, a decepção.

Ao ser questionado sobre a relação com as pessoas, o Sr.Jair diz - em um primeiro momento - que nada mudou, mas logo pergunta se a pergunta tratavase sobre abandono ou isolamento; evidencia-se a ligação entre ter deficiência e ser/estar isolado. De acordo com Ribas ${ }^{17}$, o atual discurso politicamente correto censura as referências negativas quando se fala publicamente sobre uma pessoa 
com deficiência, mas no cotidiano, a associação entre deficiência e um fardo pesado de carregar e difícil de suportar se mantém, continuando as trocas simbólicas que fazem perseverar a deficiência como manifestação do sentimento de que, nesta condição, talvez não valha a pena viver. Para o Sr.Jair, ao longo da entrevista, é somente aos poucos que ele consegue compartilhar as experiências de preconceito e isolamento que de fato vivencia.

"Tem um pouco de diferença no jeito que as pessoas me tratam. Eu tinha tantos colegas que conversavam comigo, mas eu já ouvi até dizer: Ah, não chama ele não que ele vai dar é trabalho, é cego, num... Eu já ouvi, assim de colega. Então, existe um pouco de diferença. Porque antes se a gente saía pra ir num futebol, a gente ia no mesmo galope, né? Agora não... Se eu for sair com um deles, pra ouvir uma apresentação de um cantor de música sertaneja que seja assim num palanque, eu já não vou na velocidade que eu ia antes. Tenho que ir devagarinho e eles precisam ir falando se tem uma subida, tem um degrau, tudo isso. Nunca senti assim ofensa, mas a atenção não é a mesma dos colegas..." [Sr. Jair].

Outras diferenças na relações da pessoa com deficiência e o mundo também aparecem. Para Ângela e Cristina, homens e mulheres vivenciam de maneiras diversas a deficiência e a experiência da limitação. Segundo Ângela, é mais difícil para um homem pedir e receber ajuda, mas o uso dos banheiros públicos é mais complicado para as mulheres. Cristina diz que os homens não gostam de compartilhar seus problemas; já as mulheres, são mais emocionais e menos pragmáticas.

"[Na deficiência] Eu acho que pra homem é pior ainda, para ajudar na rua, principalmente. Uma mulher é mais fácil um homem ajudar ou uma mulher ajudar. Agora, para usar os órgãos públicos, o banheiro, essas coisas, para nós mulheres é terrível. É ruim... Mas ajuda na rua, eu acho que para as mulheres é mais fácil." [Ângela]. 
"Eu acho que o homem é mais fechado no problema dele. Eu acho que ele fala menos, porque eu vejo meu irmão: ele fala comigo, porque a gente tem uma deficiência, mas às vezes ele não gosta de falar. Eu vejo que aquilo é um sofrimento mesmo pra ele." [Cristina].

Culturalmente, o papel masculino é voltado à produção, à produtividade e ao espaço público; às mulheres, cabe o âmbito doméstico, o cuidado, os sentimentos. E, com isso, vêm as diferenças colocadas pelos entrevistados. Segundo Silva ${ }^{57}$, este processo de aprendizado e de reprodução dos valores culturais é, freqüentemente, entendido como algo natural. A autora afirma que os valores de autonomia e independência, bem como os ideais de sujeito produtivo como papéis masculinos, e as mulheres voltadas predominantes no espaço doméstico, podem ser posições agravadas e/ou potencializadas pela deficiência.

Nesta perspectiva, as possíveis limitações advindas da deficiência podem traduzir-se em dificuldades diferentes para homens e mulheres. Nas histórias do Sr.Jair, Ricardo e Rubens, o aspecto do trabalho (especialmente a busca por trabalho dificultada pela deficiência, em seus diferentes níveis) é altamente presente e valorizado. Nas histórias de Cristina, Ângela e Fátima, apesar de viverem (ou terem vivido) o mundo do trabalho de alguma forma, aspectos como o cuidado, a família, os sentimentos são mais recorrentes.

Para Ricardo, dependendo do tipo de deficiência, haverá também diferenças de oportunidades na vida, bem como em relação a questão socioeconômica. Para ele, nos casos de deficiências congênitas, é mais difícil ter acesso ao estudo e ao trabalho; quando a pessoa adquire ao longo da vida, ele já teve uma formação anterior sem a batalha da deficiência (limitações, desvantagens, acesso e oportunidades). 
"Porque eu já vim de criança, então minhas oportunidades foram diferentes do que aquele cara que já tinha uma, uma vida de motoboy ou sei lá, mas caiu e se acidentou, ou tinha o seu carro bateu e não sei quê, e ficou paraplégico... Mas aí já tinha um suporte, tinha uma vida, tinha um trabalho. Aconteceu há dois anos, o cara já tem um carro adaptado, o cara foi colocado de novo no mercado de trabalho, continuou lá na empresa dele, foi até promovido. Tem essa coisa de ser tratado todo mundo assim, daí eu vejo que: Pô, por que você não vai lá cara? Por que você não tem o seu civic? Meu, você tá sofrendo porque você quer... Hum, tá. Não é assim, eu sei que não é assim. Isso me magoa muito, chateia muito e sempre que posso, eu falo dessa diferença. Tem, existe sim, muita. Ah, poxa, mas tem a fulana lá que, puxa, ela é tetra [tetraplégica] e ela tem uma vida, ela ganhou a secretaria, da pessoa com deficiência, ela assumiu como vereadora... Tetraplégica... Poxa, e você que mexe aí tudo cara, ô... Você tá marcando touca... Não é, né? Então tem essa parte financeira também, de suporte tem que ter, ô como tem..." [Ricardo].

O aspecto das relações afetivas e sexuais da pessoa com deficiência é trazido por alguns entrevistados. Ricardo vivencia cobranças de colegas e amigos para que se envolva romântica ou sexualmente com pessoas com deficiência; segundo relata, ele é tachado como preconceituoso por ter tido poucos envolvimentos com cadeirantes. Para Fátima, há uma condição de menos valia para a pessoa com deficiência, dizendo que é muito difícil uma pessoa que não tenha deficiência envolver-se com uma que a tem. Ela menciona ainda um olhar de preconceito e estranhamento da sociedade diante destas relações.

"[As pessoas fazem diferença pelo fato de ser deficiente]. Se for cego não, mas se não for, faz... Tanto que é muito difícil um homem se interessar por uma deficiente visual, ou uma mulher também se interessar por um deficiente visual. É difícil! E a gente mesmo, por causa do preconceito, a gente não quer... Eu não quero, e as minhas colegas que eu conheço, a maioria tudo se envolveram com deficientes visuais. [...] Mas a gente não 
se envolve com pessoas que enxergam, porque 0 preconceito é grande. Mesmo que ele se envolva, mas ele quer deixar a mulher em casa, não quer sair com ela. É muito raro, muito raro, os deficientes que a gente conhece, serem casados com pessoas que enxergam, tanto faz da parte do homem como da mulher" [Fátima].

Para Rubens, o fato de nunca ter namorado está relacionado à sua deficiência:

"[Nunca namorei], sei lá... Nunca quis... [Tenho vergonha do problema da fala]. [Elas] não [gostam], não tem [mulher que goste]." [Rubens]

Os estereótipos e os preconceitos podem estar no próprio sujeito. Para o Sr. Jair, por exemplo, há uma marca depreciativa em si próprio: a vergonha da cegueira, o não encontrar possibilidades de sentido sem enxergar, ele não consegue reconhecer seu valor. Evidencia-se a vergonha de ter deficiência colocada nesta relação com o outro. O social e o contato com o outro ameaçam e envergonham, porque evidenciam somente suas limitações, remetendo-nos ao conceito de estigma e sua marca indelével ${ }^{55}$. O medo e a falta de coragem de sair na rua envolvem, além dos aspectos relacionados a acessibilidade urbana (que serão discutidos posteriormente), as rupturas e/ou as dificuldades vividas com a deficiência, e o ocupar novos lugares, ainda mais diante do estigma associado à deficiência.

Já no caso de Ângela, por exemplo, é ela quem fica preocupada quando soube que seu filho jogou bola com uma criança com deficiência, mesmo vivenciando esta condição. A convivência, segundo ela, é importante para saber lidar com estas diferenças.

"É engraçado... Na minha época, não tinha criança deficiente na sala de aula. Hoje é tão comum! Comum, comum, comum... E meu filho respeita, os outros 
respeitam. Eu falo: Mas você jogou bola com ele? Você não machucou ele? Não mãe... Não machuquei nada... Eu quem fico... Eu já não jogaria com ele, fica aquela coisa, aquele medo. [A nova geração] Encara numa boa, brinca. Como tem pra ficar zoando o outro, zoa, joga bola com o menino. Fiquei boba! Porque convive junto... Agora, você nunca viu a pessoa, ela vai entrar no ônibus, você já vai: Hum, coitadinha... Ai, como isso, acaba com a gente!" [Ângela].

Cristina entende que o "mundo dos surdos" é um mundo diferente das outras pessoas, que não tem deficiência auditiva. Há, na sua própria compreensão, uma segregação entre surdos e não-surdos; porém, ela pondera que o preconceito pode estar nela.

"Às vezes, eu acho que o mundo é feito pra quem não tem deficiência nenhuma. As coisas, o trabalho... Ou porque minha deficiência tenha vindo progressivamente, então eu não tô no mundo do surdo totalmente. Eu ouvia e agora ela tá caindo... Então, eu não conheço outro mundo, o mundo do silêncio. Mas, talvez, o preconceito esteja dentro de mim. Talvez seja isso..." [Cristina].

\subsection{2 - Explicações e construção de sentido}

Três categorias principais de explicações sobre a deficiência emergem do discurso dos entrevistados: a religião (associada a idéia de castigo, culpa, transcendência ou aprendizado), a noção de acidente e/ou fatalidade, e a genética/hereditariedade.

"Por que será que aparece a deficiência na vida das pessoas? Não deveria existir... Nem sei da onde que vem isso aí... Será que é castigo, será que o cara é merecedor? Acidente? Eu trabalhei numa firma de metalúrgica, e todos eles faltam um pedaço de dedo... Então vai dizer que todos aqueles merecem? Sei lá eu, por isso num dá pra você explicar... É merecedor a pessoa? Sei lá, é castigo? 
Acho que é coisa que num tem explicação não... É coisas da vida, que nem fala..." [Sr.Jair].

"[Em relação a deficiência] Uns já nascem, outros é por causa de uma bala perdida. O meu caso é difícil de entender, porque eu não nasci assim, não foi bala perdida, não foi tombo, não foi nada... Então por que eu tenho isso? Eu não entendo também... $E$ ninguém sabe... Até agora ninguém falou: Olha, é por isso, por isso... Eu acho ruim, no meu caso, porque pra dar explicação para os outro..." [Ângela].

"A minha limitação é genética. Não é coisa que eu provoquei, vamos dizer, não é acidente, alguma coisa assim. Eu queria ouvir normalmente, não como explicar essa coisa da limitação. Às vezes é ruim... Não é bom... [...] Eu acho que a gente tem que realmente aprender a conviver com isso. Não tirando vantagem, mas às vezes, você até se dá um pouco mais, por causa da sua deficiência. [...] Eu sempre tento compensar e compreender as outras pessoas com deficiência. Eu tenho que compreender o outro, entender o outro, o quando é difícil... [...] Gozado... Por que a gente tem que ser assim? Por que eu tive que nascer com essa deficiência? Geralmente eu não pergunto por que, mas o para quê. Tem algum motivo..." [Cristina].

"Eu acho que Deus dá um tipo de deficiência a uma pessoa que tem uma prova que não deve, e às vezes a pessoa reconhece o amor Dele por nós. No médico, eles falam que são coisas genéticas, problema do pai e da mãe, que transparecem no sexo... Mas muitas das vezes, Deus escreve certo com você... Porque é assim: se você tem uma deficiência ou um tipo qualquer de problema, e você se revolta contra Deus, é pior ainda... Então você busca - é a minha opinião - aquela força Nele, e você encontra... Quando eu era mais nova, eu não entendia a palavra de Deus... Eu cheguei ao ponto de pedir que Deus me levasse. Agora não! Se eu estou aqui, é porque algum propósito o Senhor tem na minha vida. E nada acontece por um acaso! Eu ainda creio que Deus tem algum propósito na minha vida, seja ele qual for... Pode ser que eu ainda vá ser uma pessoa infeliz, e pode ser que eu ainda vá ser uma pessoa mais feliz do que sou... Então 
por isto que eu não reclamo, não me revolto, e eu vejo assim... Se Deus deu um filho pra morrer pelo mundo inteiro, pela humanidade, porque nós também não podemos carregar nossa cruz numa boa? Eu não reclamo não. Pra mim, a deficiência é assim..." [Fátima].

A relação da deficiência com a religião é muito antiga, e há um legado de representações que fazem das pessoas com deficiência figuras ora temidas e amaldiçoadas, que precisam ser excluídos do convívio social, ora seres semidivinos que deviam ser objeto de caridade por parte das pessoas com quem conviviam $^{12}$. Pereira ${ }^{9}$ completa esta idéia, ao mencionar aspectos da deficiência existentes no texto bíblico: há várias referências mencionando-a enquanto castigo, algumas apontando conotação sobrenatural e, ao mesmo tempo, leis de proteção divididas por tipo/categoria (cegos, surdos, aleijados).

Muito religiosa, Cristina encontra em uma passagem bíblica o significado de sua experiência e de suas dificuldades, incluindo a questão da sua deficiência: é a história de Abraão, que levou o filho ao sacrifício para provar sua fé em Deus.

Cada um, com sua história, crenças, concepções e vivências concretas, vai encontrando e construindo significados para a sua própria vivência de ter uma deficiência, tendo na aprendizagem e na transformação focos importantes de sentido. E, estas experiências vão sendo ressignificadas ao longo do percurso da vida (e até mesmo no próprio processo de produção do discurso, na entrevista).

"Acho que a própria condição que eu tô hoje é pra que eu aprender, que eu tenho que aprender um monte de coisa... Acho que se não tivesse numa cadeira, eu ia ser uma pessoa muito prepotente. E aí aqui não, debaixo tem que enxergar um monte de coisa, um monte de detalhes aqui que..." [Ricardo].

"Eu sou batista, eu tenho uma fé muito grande em Deus, Ele que me guia apesar das coisas; eu acho que a gente 
não tem que ter uma vida mansa, a gente tem que ter a vida que a gente tem que ter, crescer, e Ele está junto ali ajudando, não é porque a gente tem que ter uma vida sem problemas. Acho que os problemas têm que existir mesmo pra você amadurecer, crescer, valorizar, saber lá na frente confortar o outro que tá passando por aquilo. São experiências de vida que eu acho que são muito importantes pra gente" [Cristina].

Estes sentidos, significados, valores e concepções banham a relação entre as pessoas no mundo. A questão da deficiência - em seus diversos aspectos - é uma questão do encontro com a diferença, do relacionar-se com o que diferente, com o "outro". Esta relação de alteridade faz a mediação da pessoa com deficiência consigo própria e com o mundo, como foi possível observar nos aspectos abordados anteriormente.

A partir das histórias colhidas, é possível observar que, na vivência da deficiência, estão envolvidas características pessoais (história de vida, personalidade, família), bem como aspectos socioculturais (contexto histórico, crenças, valores, concepções). Muitos sentimentos são mobilizados: raiva, inconformismo, nervoso, ansiedade, ambivalência. Segundo Ricardo, as pessoas com deficiência tendem a dois pólos: a imagem de "coitadinho" ou "vestir a capa de super-homem" e, para ele, ambos são ruins e o sujeito precisa refletir sobre si mesmo e encontrar um equilíbrio, movimento que ele próprio relata fazer. Ricardo e Fátima ressaltam ainda que "deficiência não é atestado de idoneidade" (nas palavras de Ricardo) e que "tem o deficiente que tem dificuldade e que precisa de ajuda e tem o deficiente que é folgado" (nas palavras de Fátima) isto é, são sujeitos humanos como quaisquer outros, com defeitos e dificuldades.

Conforme trazido pelos relatos, Pereira ${ }^{9}$ afirma que a vivência da deficiência poderá trazer ao sujeito uma imobilização no arquétipo do coitado ou no arquétipo do herói. Para o autor, uma identidade construída a partir da 
deficiência irá requerer do indivíduo um movimento de articulação entre as experiências, pensamentos e atitudes abordadas aqui, possibilitando que a diferença funcional de cada um seja vivenciada como uma história, um patrimônio existencial e emocional, produtor de subjetividades.

\section{2 - Independência, autonomia e apoio}

A autonomia e a independência são questões centrais no discurso dos sujeitos entrevistados, necessidades identificadas como algo que propicia senso de dignidade e liberdade. O que Cecilio ${ }^{21}$ coloca como um dos conjuntos de necessidades de saúde, a "autonomia nos modos de andar a vida", é contemplada no limite no caso das pessoas com deficiência; as incapacidades advindas da deficiência fazem sobressair ainda mais a necessidade de autonomia, e também independência, sendo esta muito valorizada.

"Eu consigo fazer quase tudo sozinho. Estando na minha casa, a parte da limpeza, a minha higiene pessoal eu cuido eu mesmo; até mesmo questão de roupa, eu cuido, eu passo. Não gosto muito, tenho dificuldade, lógico, mas eu posso fazer. Agora, o que eu não posso fazer é meio de locomoção. Aí eu vou precisar mesmo. Por enquanto, no estágio que eu me encontro hoje, como pessoa com deficiência, as minhas limitações são as minhas forças, e faz com que eu me vire bem no meu dia-a-dia. Eu consigo fazer transferência sozinho, consigo fazer a limpeza do meu banheiro sozinho, o meu quarto também, arrumar a cama, dobrar a roupa. Então, isso aí, tudo bem, agora quando passa a ter que ir em determinado local, aí tem que ver se precisa sim, se precisa de alguém pra levar." [Ricardo].

"[Tenho dificuldade] Só no que eu não sei... A única coisa que eu tenho dificuldade é de costurar. Só isso! Assim, pode ser que apareça outra coisa que eu não fiz, provavelmente eu vou ter dificuldade, mas lavar, passar, 
cozinhar, limpar, fazer comida, isso eu não tenho. Limpar minha casa, arrumar minha casa... Tudo! Não tenho dificuldade... Fazer supermercado..." [Fátima].

Fátima valoriza também a necessidade da pessoa com deficiência ser permitida a aprender, a experimentar e a - concretamente - realizar tarefas e atividades de maneira independente, seja por parte da família quanto das instituições:

"E tem uma coisa de bom, a minha mãe, ela nunca me criou como deficiente visual... Ela sempre foi uma pessoa que me ensinou a fazer tudo... Tudo! [...] E graças a Deus, a minha mãe ela nunca me criou como deficiente visual... Graças a Deus! Eu louvo a Deus por isso, porque também se tivesse me criado, tinha me paparicado muito e eu tinha sofrido mais... [...] São essas coisas que a família precisa deixar fazer, a família precisa incentivar, e - Lar aqui também precisa incentivar, porque vai ser muito pior lá fora ou com outra pessoa. [...] Primeiro já começando pela família: tem que incentivar a fazer, dando prejuízo ou não, e quando estiver na escola, a escola não tem que paparicar, porque se paparicar..." [Fátima].

Ricardo busca ser auto-suficiente em todas as atividades, e aceita com dificuldade ajuda de seus vizinhos; em relação aos familiares, pouco aceita ajuda ou contato. Parece haver um custoso movimento de afirmação das capacidades. Entretanto, aponta para o fato de todas as pessoas serem dependentes umas das outras de alguma forma:

"Quero ter, procuro ter minha vida independente, e dependo sim de um monte de gente, acho como todo mundo depende... Eu mais um pouquinho mais. Procuro ter a minha vidinha assim, até quando der." [Ricardo].

Diniz $^{15}$ ressalta que a sobrevalorização da independência é um ideal perverso para muitas pessoas com deficiência, pois há aqueles que têm 
incapacidades mais graves e que jamais terão habilidades para a independência ou capacidade para o trabalho, não importando o quanto as barreiras sejam eliminadas. Para Pereira ${ }^{9}$, considerar a independência como regra ou ideal único a ser atingido reflete o preconceito sobre as pessoas com deficiência; segundo ele, ter independência e/ou autonomia limitadas não implica necessariamente em uma vida menos feliz, com menos qualidade, ou menos desejável julgamento em vigor neste modelo.

Ângela ressalta que há situações em que pessoa precisará de ajuda sim; ela mesmo percebe que não tem condições de sair sozinha para andar na cidade e precisa que um familiar a acompanhe. O importante é o jeito deste acompanhante estar junto da pessoa com deficiência, e a relação que entre eles se estabelece. Para o Sr.Jair, a assistência de outras pessoas no cotidiano também é muito importante, com respeito, compreensão e cooperação.

"[A principal dificuldade é] Andar na rua, principalmente. Porque se eu esbarro nos outros, às vezes caio, e não posso; por isso, eu não posso mais sair sozinha na rua, ninguém deixa. Pegar um ônibus... Isso é terrível! Nossa, ontem mesmo eu tinha acupuntura, a Roberta ia comigo, eu falei assim: Ah, não Roberta... Deixa que eu vou sozinha... Depois eu: Não, vou ligar pra lá e vou ver se eu posso desmarcar... Porque eu de bengala, de guardachuva, de ônibus, não ia dar certo. [...] E o acompanhamento que eu digo não é a pessoa vir com você, mas em casa, não se afastar ou ficar com dó de você, não deixar você fazer nada. Isso acaba com a gente! Claro, tem que ter cuidado com a gente, mas não precisa ser aquele cuidado que chega a ser pegajoso, irritar..." [Ângela].

"As pessoas com deficiência precisam de tratamento assim, de condução. Pra andar assim, por exemplo, dentro de um supermercado, precisa de muita ajuda, muita compreensão, às vezes cooperação. Até na rua precisa muito; às vezes você vai passando, tem uma pessoa sentada, não tira o pé, às vezes a calçada está... Eu aqui 
não, eu já não tenho essa dificuldade, mas seria bom que todo ser humano entendesse. [...] A assistência é muito bom, isso é muito necessário pro deficiente. Ele se sente mais seguro, se sente mais à vontade, aí pra andar na rua. Aqui mesmo quando eu passo no ponto de ônibus, tem os cobradores, que sempre eles fica conversando ali: Dá licença que nosso amigo vai passar... Então eu acho que tudo é importante... Todo mundo deveria ter essa ajuda, essa compreensão por parte de... o respeito. Todo, todo deficiente deveria ter, é gostoso pra ele, ele vai se sentir assim, até mais aliviado. [...] Agora, tem muitas coisas que você precisa de ajuda, fica dependente mesmo. Quando você tem uma pessoa que te compreende, aí dá pra você ir levando, mas se você pegar... que eu já vi tanta gente reclamar de não ter atenção... Eu digo, deve ser dolorido" [Sr.Jair].

Cristina vivencia a questão da dependência por outra ótica: sua deficiência auditiva permite total independência, com adaptações, porém sua mãe tem uma doença neurológica avançada e exige cuidados e supervisão diária. Em sua fala, é possível destacar como é difícil também para o familiar, que tem sua rotina alterada.

"Por isso que eu acordo muito cedo, eu acordo quatro e meia para sair de casa às seis. Eu deixo tudo assim, programado: o almoço, o café, o comprimido, a fruta, tudo bonitinho pra ela, tudo pronto. [...] Quando eu chego também, não dá tempo, eu já chego trabalhando, já começo arrumar uma coisa, limpar a casa, tem que ir no mercado, tem que fazer comida no outro dia. Então essa luta... [...] Cansa, cansa... Eu fico bastante cansada... [...] Ela [a mãe] não pode ficar sozinha, ela não consegue. A gente tem que dar banho nela, ela perdeu a noção do limpo e do sujo; ela vai no banheiro, eu tenho que ir junto com ela, eu tenho que dar o papel pra ela se limpar, botar fralda. É mais que um bebê... [...] Você tem que ir forçando as coisas; mas, é difícil, é bem cansativo. [...] Parece que, nesse tempo, a nossa vida tá se resumindo ao redor dela; fica tudo meio ao redor da mãe: o que eu vou fazer, como é que eu vou me encaixar, quem vai ficar, como vai ficar, fazer isso pra minha mãe, levar minha 
mãe... Então você fica meio de lado... Eu não me incomodo... Nesse cuidado, às vezes me canso. Cansar acho que é normal, porque a mente fica cansada, o físico cansa..." [Cristina].

A família pode ser importante rede de apoio para os cuidados à pessoa com deficiência; porém, cada configuração e funcionamento são peculiares àquele núcleo familiar específico. Sr.Jair, Cristina, Rubens e Ângela vivenciam relações de apoio e ajuda com seus familiares; já no discurso de Ricardo e Fátima, ficam mais explícitos os conflitos e as dificuldades que permeiam a convivência familiar.

De toda maneira, a deficiência afeta (de algum modo) os familiares, que podem até passar à quase exclusiva função de cuidadores, seja nos casos de deficiências congênitas ou adquiridas. Segundo Pereira ${ }^{9}$, seja em deficiências congênitas ou adquiridas, a ocorrência de uma deficiência altera - em maior ou menor grau - os modos de vida da pessoa e da família, considerando-se também o universo sociocultural no qual estes estão imersos, uma vez que nele (e a partir dele) estão colocadas as concepções, as explicações e os comportamentos próprios daquele contexto.

Na história de Ângela, por exemplo, além das irmãs e sobrinhas, que se organizam para acompanhá-la aos tratamentos, é o filho quem sente a ruptura do adoecimento: a carência, a falta de atenção, o não ir às reuniões da escola.

"Eu acho que ele ficou um pouco perdido [depois da doença da mãe]. Tem dia que eu nem fazia carinho nele; ele queria abraçar, porque ele adora me pegar pra dançar... Falava: Mãe! Vamos dançar? Vamos dançar? Ele adora isso... Ou pegar assim e me abraçar. Ele me pega no colo, eu não posso porque dói muito as minhas costas... E, sair com ele, então nunca mais eu fiz nada disso com ele... [...] Mas, eu deixei ele um pouco de lado. $\mathrm{Na}$ escola, eu ia sempre: teve época em que eu não estava indo nem na reunião dele. Esse ano eu já fui a 
duas. [...] Nunca mais eu andei com eles na rua, de bicicleta. [...] Eu tinha mais cuidado com ele, me preocupava mais com ele. Eu me preocupava e agia... Agora não. Agora eu fico preocupada e fico pensando: Ai, como que eu vou fazer? Vou pedir pra minha irmã fazer..." [Ângela].

Emergem também aspectos do relacionamento entre os familiares e a pessoa com deficiência, com tendência à superproteção.

\begin{abstract}
"As outras não, elas me tratam com cuidado. Tem horas que me irritam esses cuidados demais. Me segurar muito na rua: eu vou disfarçando e tiro o braço, porque eu quero aprender a andar sozinha. Mesmo que ela está do meu lado, mas eu quero que me solte um pouco. Isso me deixa um pouco chateada, mas elas agora já percebem melhor. Porque parece que te protege demais. Não agüento isso!" [Ângela].
\end{abstract}

Já na história de Fátima, conforme abordado anteriormente, ficam mais explícitos os conflitos vivenciados por ela junto aos familiares, relacionados à temática da deficiência. Preconceito, isolamento e superproteção são alguns dos temas que aparecem. É importante ressaltar que, de toda forma, ela valoriza a necessidade de apoio para as pessoas com deficiência.

"O médico me indicou esta escola, mas a minha família não queria que eu viesse estudar... Eu voltei pro norte de novo, pra casa do meu pai... Quatro anos eu passei lá; com vinte e nove anos decidi que eu ia estudar. Mas, meu pai não queria que eu viesse. Eu falei: 'Ah, vou!'. Voltei, cheguei, minha família também não me deu maior apoio para eu estudar. Eu decidi que iria estudar... Graças a Deus naquela época tinha o internato, eu vim morar aqui. Eles começaram a colocar muito empecilho; a diretora falou: 'Olha! Você vai ter que escolher, ou a família ou a escola...'. Eu optei pela escola, e abandonei a família, porque eles não me davam maior apoio em nada... [...] $\mathrm{O}$ que mais me chateou, o que mais me deixa assim, triste, 
é não ter apoio da família. Nós éramos seis irmãos; um ficou lá, o caçula veio pra aqui quando eu vim e não deu noticias, nunca mais foi lá ver o pai, e tinha três aqui, que eram os mais velhos. Sempre em Santos... Eles casaram... Mas só que eles aqui também não me davam apoio... [...] Olhava as crianças, cuidava da casa e tudo... Só que quando era pra eu estudar, para eu crescer, eles não queriam... Foi aí que eu saí... [...] Então eu fico triste porque eu tenho mais apoio de pessoas estranhas do que da minha família... [...] [Sobre o pai] Não sei se ele não gosta, ou não tem ou não sabe... Agora esse meu irmão, ele tinha vergonha..." [Fátima].

\begin{abstract}
Ainda relacionado à família, podem haver preocupações em torno do representar uma sobrecarga aos familiares; o medo de uma possível dependência, ou de uma piora nesta condição, é um fardo e uma preocupação constante destes sujeitos.
\end{abstract}

"Eu tenho medo de piorar. Porque eu acho que agora já tá difícil, imagina se eu envelhecer piorando. Por isso que eu não posso parar, tenho que fazer em casa. É continuar, porque eu tenho medo. Eu tenho medo de ficar travada. Morro de medo; e velha ainda... Dá dó, e o trabalho que dá pras outras pessoas... Eu não suporto ficar dando trabalho. Assim eu já dou trabalho, imagine... Mas é, é verdade!" [Ângela].

A família é motivo de preocupação para o Sr.Jair, seja por entender-se como "fardo", já que precisa de ajuda e acompanhamento em muitos momentos, seja pela preocupação com o fator hereditário de sua deficiência visual, a qual pode agregar outros sentimentos de culpa e insatisfação neste campo relacional.

"Eu fico preocupado com a minha família, principalmente meus dois filhos. O que eu perdi, como eu sinto falta da minha visão, jamais eu vou querem pra eles. Então, sinto preocupação com filho, com neto... sempre... [...] Na minha família, não percebi nada assim de abandono, de desprezo. Eu acho que eles se preocupam um pouco. Eu 
tenho umas irmãs, quando eu vou na casa delas, elas me dá bem mais atenção do que antes. Porque antes eu num tinha problema nenhum, eu me virava em tudo, mas hoje não, mudou muito. Elas me dão bastante assistência. [...] Para minha família, o dia-a-dia não mudou muito não. Eles me tratam bem. Meu filho trabalha, os dois trabalham normal. Se eu precisar, ele me levam num lugar. Nunca vi eles reclamar não, sabe..." [Sr.Jair].

Mas é a partir da esposa, que outro aspecto aparece:

\begin{abstract}
"Despedimo-nos novamente; a esposa me acompanha até o carro. Conta-me que ele é um homem muito nervoso, e que na sua opinião ele precisaria de um acompanhamento psicológico. Diz que já tentou na UBS, mas a profissional disse que ele não precisava (segundo a esposa). A esposa ainda fala que agora ele melhorou, tem saído mais, mas que é difícil para a família (principalmente ela) acompanhá-lo em tudo. A venda dos doces e salgados é um jeito de distrair-se, segundo ela; também cuida do neto e de dois filhos, que moram com o casal. Ela diz que se não fizesse tantas coisas, não iria agüentar; parece sentir-se sobrecarregada. [...] Esposa fala de sentir-se sobrecarregada por ter que cuidar do neto, porque ela já tem um "problemão" (referindo-se ao Sr.Jair) - ele percebe isso, e diz que ele a atrapalha. Ela me conta da viagem que fez este ano para o Nordeste, e que o filho tirou férias para cuidar do pai; ela diz que se não fosse assim "o mandaria para a casa das irmãs" (referindo-se ao Sr.Jair)." [Trechos do diário de campo].
\end{abstract}

Porém, é importante ressaltar que, ainda que toda a família possa vivenciar alterações, o papel do cuidado é - culturalmente - delegado às mulheres. Nos relatos desta pesquisa, são as mulheres que organizam e gerenciam o cuidado às pessoas com deficiência entrevistadas, seja irmãs, mães ou esposas, por exemplo. Cristina não precisa de ajuda, mas são as mulheres de sua família que oferecem o cuidado à mãe demenciada. Dados produzidos em uma pesquisa da Universidade de Brasília ${ }^{57}$ sobre gênero, cuidado e deficiência corroboram esta 
afirmação; segundo a autora, a relação de cuidado na deficiência é uma tarefa familiar predominantemente feminina.

Ricardo viveu esta história. Quem acredita em seu potencial e o traz para os tratamentos é a mãe. Mas, como esta não conseguiu oferecer o cuidado diário, ele passou a infância internado em hospitais e a adolescência (até o início da idade adulta), em uma instituição de longa permanência. Este tipo de serviço pode funcionar como local de cuidados e de moradia para pessoas com deficiência, especialmente em casos de famílias sem recursos (financeiros, afetivos, organizacionais) para o cuidado; porém, é um modelo que pode potencialmente - contribuir para o mecanismo de isolamento e de segregação das pessoas com deficiência.

"A minha passagem por aqui, na vida, é graças a minha mãe, senhora que no passado tinha filhos com parteiras [...] de falta de cuidados médicos, porque era difícil e tinha que viajar no meio do mato, de cavalo, de madrugada. Minha mãe teve mais de dez filhos, de parto; agora, que ficaram vivos, até o ano passado, cinco. $\mathrm{E}$ desses cinco, ela bateu o pé e falou: Não, esse não vai! $E$ meu pai, tão xucro: Ah! Mas pra que tanto cuidado? Se não tem condição de viver, é a seleção natural... Mas se Deus quiser, vai ficar por aí... E graças a Deus que uma, quis, e outra, que a minha mãe quis, foi atrás, não tinha condição. [...] Mas também a vida não proporcionou que a gente vivesse junto, eu sempre tive que viver em hospital, mas ela sentiu orgulho por isso, de falar que não e bancou isso." [Ricardo].

É importante observar que durante a infância, a saída do hospital foi bastante difícil. Afastado do convívio familiar diário, retomar este contato, voltar ao meio rural, acabaram - segundo ele - por piorar sua condição, pois não havia serviços de acompanhamento disponíveis. O critério para esta alta foi a reabilitação da marcha, isto é, com um olhar somente para o corpo de Ricardo, sem considerar sua rede familiar e social de suporte. A saída da instituição 
também é permeada por conflitos, feita de maneira rápida e sem haver este vínculo familiar; é uma família que visitava a instituição que acaba ajudando-o.

\begin{abstract}
"E viver com essa coisa da ansiedade; não foi trabalhado muito bem essa saída da instituição. Tinha psicólogo, tinha assistente social, que na ponta final foi ela que colocou todo mundo pra fora, e me colocou também. 0 que eles tavam propondo era colocar numa perua um grupo, fazia uma rota, e ia entregando aqui em São Paulo. É, o tratamento já se deu, não vai evoluir mais do que isso aí... Não, mas olha eu não tenho condição financeira, não tenho estrutura, não tenho... Ah não tem? Mas é filho, cuida... Então vai ficar na rua, e aí muitos aí é... Acho que poucos a família recusou. Sai mais estruturado porque tive um respaldo melhor pra estudar, alimentação... Tinha tudo lá dentro, na instituição, tinha tudo e não tinha nada, porque é um mundo fechado. Um mundo fechado, um mundo de certa disputa até, por viver num ambiente de instituição, não ter o lado da família, o carinho da família, e você ter que se tornar forte pra você continuar vivendo lá dentro." [Ricardo].
\end{abstract}

Ricardo aponta que em algumas situações - especialmente no contexto do trabalho - a ajuda pode ser vivenciada de maneira positiva, contrapondo-se à superproteção ou ao preconceito e segregação, e ele valoriza este posicionamento. Ele afirma ainda que há situações em que será preciso fazer uma análise do risco desta ajuda, mesmo que adequada e bem intencionada; no seu caso, por exemplo, o uso da cadeira de rodas pode envolver quedas. Ricardo também ressalta que, por vezes, a ajuda será necessária e bem vinda, e novamente - a postura daquele que auxilia é o diferencial.

"Lá no começo, não cheguei a enxergar preconceito não. Mas assim, até mesmo uma compreensão dos colegas: Ah, tá com dificuldade de integrar e tal... A gente sabe que sua oportunidade de estudo foi outra e não esquenta não... O sistema aqui é esse mesmo, então entra aqui, e fecha aquela tela ali e tal.... Vai indo cara... Eu tô aqui do 
teu lado... Então, tem muito de companheirismo. Isso num primeiro momento, de pessoas que não tinham deficiência e nada, uma empresa que não tinha; parece que eu fui um dos primeiros lá, naquele momento estava somente eu. E não teve superproteção, mas teve compreensão, então acho que isso já ajudou bastante. [...] Agora, as pessoas são muito solidárias, mas como pessoa com deficiência, eu tive que adquirir maturidade. Não é só a pessoa querer me ajudar, mas eu tenho que, naquele momento ali, fazer uma análise de risco. É uma coisa muito rápida. Então eu nego, e tô negando porque eu sei que tem risco. [...] Aí muita gente não entende esse lado não... Acha que é orgulho e que não quer ser tocado" [Ricardo].

Os apoios no lidar com a deficiência, bem como na vivência cotidiana, é relatada e reconhecida pelos entrevistados, sempre se ressaltando a importância uma postura de compreensão daquele que ajuda. Aspectos financeiros, emocionais e organizacionais são alguns dos âmbitos a que isto está relacionado, e sua fonte pode ser, além da família, os amigos, os profissionais de saúde, as instituições (filantrópicas ou não), os prestadores de serviços, entre outros.

"Eu falo com a minha sobrinha que é ótima, tem trinta anos, a gente conversa muito. Eu falo com a minha irmã, eu falo com os meus irmãos, eu falo com pessoas que você tem uma amizade melhor e aquilo vai te aliviando. Às vezes, elas podem te ajudar de alguma forma, te dar um lamento, mostrar um caminho diferente..." [Cristina].

"Falei: Então vou ter que me bancar... E não fiquei triste por isso. E como que eu me banquei? Tive um apoio, lógico; de uma família que visitava a instituição... [...] Então tem essa parte financeira também, de suporte tem que ter, ô como tem..." [Ricardo].

"... Outra, você vai conversar com alguém, vai fazer novas amizades... Vai chegar dia em que você pensa assim: Ah, eu não quero ir... Ah, mas fulano vai hoje, que eu quero conversar, não sei o quê... Incentiva a gente, eu acho que é bom." [Ângela]. 
"No momento, os deficientes eles precisam de tudo. Principalmente apoio... A sociedade tem que apoiar mais, em todos os tipos, nas situações do emprego, na situação do transporte, na situação da ajuda pra atravessar. [...] Em primeiro lugar, o deficiente - tanto faz o visual, como o cadeirante - [precisa] ser mais visto na sociedade e a sociedade acreditar que a gente é capaz. E apoio da família, isso é muito importante, é o que eu não tive... Isso é muito importante! O apoio da família..." [Fátima].

Para além dos aspectos relacionados às causas e explicações acerca da deficiência, já trabalhados, a fé e a religião são também fontes de apoio, provendo conforto, consolo e explicações para as vivências difíceis.

"A força que eu tenho é Nele. Eu peço toda noite, agradeço todo dia. No dia seguinte eu agradeço pelo dia de hoje. Não sou contra também as outras religiões, não... Cada um é cada um, tem fé num Deus, que só existe um Deus né... Não existem vários deuses não... Eu sempre eu gostei, mesmo no tempo de solteiro, no tempo de garoto, sempre gostei de ir na missa, assistir a missa aos domingos. Minha mãe sempre foi também de dentro da igreja... Me sinto bem quando vou, parece que sai mais leve de lá." [Sr.Jair].

"[A força] Vem de Deus mesmo. Ele é o meu centro. Ele que me dá compaixão pelo outro, amor pelo outro, a compreensão, a paciência com a minha mãe, com as coisas. Eu acho que Ele me norteia, sem Ele eu ficaria realmente perdida. Eu me converti quando eu tinha dezessete anos e, então, eu o conheço há trinta e três anos, eu tenho cinqüenta anos. Eu sou evangélica... Não teve um dia que Ele não estivesse realmente comigo, todas as vezes, todas as provas que foram difíceis... [...] Fé é aquilo... A gente crê naquilo que a gente não vê... Eu não posso ver meu futuro, posso achar que meu futuro é tenebroso, eu não vejo meu futuro, eu boto Ele na frente. Ele é a ponte. Ele vai na frente, acertando meu caminho. É assim que eu vejo... Essa tem sido a minha força... Eu sigo ela..." [Cristina]. 


\section{3 - Acesso e direitos}

Em suas mais amplas possibilidades e interpretações, a questão do acesso e dos direitos é de fundamental importância para as pessoas com deficiência, uma vez que permitem a ampliação do ser/estar no mundo, e na "autonomia dos modos de andar a vida", sendo amplamente abordadas no discurso dos entrevistados.

Neste quesito, a informação desponta como um tema importante. Ricardo trabalha com a idéia de que são necessárias informações sobre o acesso aos serviços, sobre os direitos das pessoas com deficiência, sobre os trâmites burocráticos na dispensação de medicamentos e dispositivos de auxílio, entre outros. Fátima também valoriza a informação, e aponta que saber sobre seus direitos como cidadã transformou seu estar no mundo.

"E direito a informação. Acho que cidadão, não só a pessoa com deficiência, mas o cidadão em si... Se ele tiver a informação, ele sabe onde buscar, ele sabe que caminho tomar, ele não vai ficar vagando e achando que é injusto..." [Ricardo].

"Antigamente, meu Deus do céu! Eu não tinha coragem de conversar com ninguém, de jeito nenhum... Eu não conhecia nada, não conhecia nada de lei... Só que agora não... Teve muitas reuniões e daí a gente foi conhecendo os nossos direitos, quais eram os direitos dos deficientes... E aqui também, eles buscaram muitos direitos dos deficientes visuais e foram passando pra gente. O serviço social, a direção... Elas foram atrás dos direitos e foram passando pra gente. E aí eu fui crescendo, então hoje em dia eu não tenho medo de falar com qualquer um, e nem de ir buscar. [...] E tem outra coisa... Eu lutei muito pra chegar aonde eu cheguei... Eu lutei muito! Eu perdi muitas noites de sono, eu chorei muito. Acho que eu chorei o que eu não tenho mais que chorar... É por isto que eu não abro mão dos meus direitos pra ninguém. Pra ninguém... Sem exceção! Só pra Deus..." [Fátima]. 
O acesso é considerado uma questão fundamental ao se pensar a vida e o cotidiano das pessoas com deficiência, inclusive pelos profissionais que prestam atendimento a esta população. Segundo Othero e Dalmaso ${ }^{58}$, em pesquisa realizada em uma unidade básica de saúde sobre a representação dos profissionais acerca da deficiência, o acesso em seu sentido ampliado (oportunidades, circulação na cidade, serviços e recursos disponíveis) foi identificado por eles como uma das principais necessidades de saúde das pessoas com deficiência.

Além da saúde, trabalho, educação e lazer são aspectos abordados pelos entrevistados. Ricardo conta que freqüentou a escola na instituição de longa permanência na qual morava, mas ao sair de lá, teve dificuldades em retomar os estudos. Por ter uma deficiência deste muito jovem, boa parte de sua infância foi vivida em hospitais e instituições de tratamento, o que também dificultou o acesso aos estudos, corroborando sua opinião de que a deficiência congênita pode agregar maiores dificuldades de oportunidades.

"Acho que a sociedade, todos nós, temos dar um jeito de ver todo mundo, por igual, é todo mundo deficiente; ou adquiriu de criança, ou foi uma doença, ou foi acidente, que a maior parte agora é. Aí a sociedade toda vê todo mundo com um todo, né? Ah, tudo deficiente, é tudo do mesmo jeito, todo mundo teve a mesma oportunidade, de estudar... Então, não é assim, eu defendo que não é... [...] A minha alfabetização foi meio complicado, porque vivia mais em tratamento, internado, do que um ambiente normal, que pudesse freqüentar a escola e tudo. Me lembro até que, no começo, eu era colocado junto com as crianças com problemas mentais, e aí eu queria aprender a ler e falava isso pra quem tava instruindo, mas como era no atacadão, era todo mundo junto... Então a coisa foi indo, e não era só eu; tinha mais, outros ali... E eu não entendi essa coisa de problema mental. Depois eu fui entender que ia me ajudar no meu desenvolvimento, mas 
eu acho que isso ficou retardado... Hoje eu tenho muita dificuldade de assimilar muita coisa." [Ricardo].

No Brasil, o acesso a educação e emprego é difícil para boa parte da população. A deficiência, as incapacidades e as desvantagens dela advindas, bem como as diferenças de oportunidades, tornam este acesso ainda mais complicado para as pessoas com deficiência. Ricardo vivencia, ao tentar retomar o supletivo, dificuldades de vários outros brasileiros, com ou sem deficiência.

"Hoje eu tenho ensino médio. Até a oitava série, tive um calço bom, mas o colegial foi supletivo. Isso depois da instituição, aí eu por minhas contas mesmo, supletivo à noite, fui indo. Quando deixavam tinha aula, porque na periferia é assim: se deixavam, tinha prova, quando não tava todo mundo com nota. E eu não podia falar nada. Eu tentei falar alguma coisa: Ah, não... Mas, onde você mora mesmo? E, por conta de eu ser acolhido, eu morei no Parque dos Príncipes [bairro de classe média alta, próximo ao Jaguaré], lá uma casa boa, um bairro bom, e mais ou menos que eles sabiam. A casa não era minha, como aqui hoje não é. [...] Essa parte da educação ficou defasada, ficou mesmo. Hoje eu sinto isso no mercado de trabalho: aparecem muitas vagas, boas, excelentes, mas você tem que ter um nível universitário. E aí eu não tenho. [...] Eu até penso em continuar estudando, mas aí eu teria que criar uma condição para isso. $E$, não sei se com o conhecimento que eu tenho, eu poderia tentar alguma coisa pública, porque eu sei que é mais puxado ainda pra entrar. E pra bancar, eu sei que é caro pra caramba. Então assim, aí eu fico nessa. Se eu não tenho conhecimento pra tentar numa pública, eu tenho que ter renda pra bancar. Eu fico meio frustrado por isso, e tendo que aceitar algumas vagas que... Acho que podia estar melhor, podia estar numa parte administrativa, e a porta de entrada é o currículo mesmo, os seus conhecimentos. Então, não tem como não." [Ricardo].

Em relação à escola, Rubens viveu muitas dificuldades, não conseguindo cursar o ensino fundamental; estudou somente por um pequeno período, até os 
seis anos. Inserido na escola regular, a dificuldade de acompanhar as tarefas propostas pelos professores e o preconceito vivido na relação com os outros alunos, o fizeram desistir quando tentou estudar o supletivo, já adulto.

"Gostaria [de saber ler]. [Depois de adulto, fui para a escola] Lá em Bueno Brandão, mas não dei bem com a molecada, [com] os moleques pirracentos lá. Os professores não, eles eram bons... Mas, saí... [...] [Fui na escola com] Seis anos. Era longe daqui. [Ia] de ônibus, é longe... Três quilômetros, no quilômetro dez. Tem ainda [a escola], é [antiga]. Eu tava aprendendo a ler, [mas] eu não sei fazer... A professora fala, você escreve... Eu não sei fazer a mesma coisa que ela faz... Nem uma conta eu sei fazer... Eu não fazia... Eu sei fazer na calculadora, na cabeça eu não sei fazer. Tinha [muita gente na classe], [a professora] ensinava, não sei [porque não aprendi]. Eu ouvia... Eu não sei o que a professora fala e tem que escrever... Me mandaram embora. Eu fui lá, ele me deu um papel e eu não fui mais. Não sei [se gostaria de voltar a estudar]" [Rubens].

$\mathrm{Na}$ entrada no mercado de trabalho, Ricardo relata que as cotas para pessoas com deficiência de fato o ajudaram, assim como as instituições que promovem a inclusão no trabalho também ajudaram. Publicada em 24 de julho de 1991, a lei No. 8213/91 implementa uma reserva legal de cargos e empregos públicos e postos de trabalho para pessoas com deficiência; porém, foi só a partir de 1999 que estas determinações tiveram efetividade ${ }^{59}$.

Entre outras razões, é a falta de formação que faz com que muitas oportunidades de emprego para Ricardo acabaram sendo deixadas de lado; a entrada no mercado formal de trabalho aconteceu somente em 2003, facilitada pela lei de cotas. Para ele, a falta de estudo (e, portanto, de qualificação) contribui para que as pessoas com deficiência não consigam emprego melhores. Aponta para o fato de que, nos processos seletivos que participou, poucos são os cadeirantes ou pessoas com deficiências mais severas. Os trabalhos artesanais, 
realizados em casa com ajuda de profissionais ou cooperativas, acabam sendo uma alternativa, mas pouco valorizada.

"Fazem uns seis anos que eu consegui entrar no mercado formal [de trabalho]. Porque até então, não trabalhava formalmente. Era artesanato, sapataria... Ganhava razoavelmente pouco, e não é valorizado. Trabalho artesanal não é valorizado. Isso em casa. E aí houve uma abertura do mercado, por conta da lei (e a gente questiona isso também); abriu-se, mas ainda tem muita barreira, ainda a gente vê que tem muita. (...) Agora, na última empresa não, porque é pela AVAPE e, quando entrou, entrou no atacadão de pessoas com deficiência. Com deficiências severas, foi um número menor. Eu lembro que o processo de seleção foi até no cursinho da Poli, ali na Lapa. Porque era muita gente, quase cem pessoas entraram. E aí entraram três cadeirantes, falei: Nossa, tudo isso de gente, só três cadeirantes? Mas pelo menos tem três né? Porque tantos processos de seleção que eu fui que só tinha eu lá, de cadeirante. [...] Precisa contratar, precisa porque vai tomar multa e eu acho que tem que entrar o negócio da multa pra eles darem oportunidades... E é bem isso que eles falam hoje mesmo, que vaga tem, agora o que não tem, é pessoas qualificadas. Isso pra mim não é novidade não, eles tão certo sim, tem vaga de gerência de banco, já apareceu pra mim, mas se não tem [qualificação], cara... Então é uma real..." [Ricardo].

Fátima recebe o benefício de prestação continuada (BPC-LOAS), benefício concedido a pessoas com deficiência com renda familiar comprovada menor que 1/4 do salário mínimo vigente, e com incapacidade para a vida independente e para o trabalho - Lei No. $8742 / 1993$, artigo $21^{60}$. A conquista deste direito foi fruto de um processo árduo de busca; o dinheiro que recebe garante o pagamento do aluguel, e resto de seus gastos é pago com ajuda de amigos e da instituição que freqüenta. Ela comenta a dificuldade em conseguir o LOAS e também as dificuldades relacionadas à busca oportunidades de emprego para pessoas com deficiência: 
"Acho que faz uns dez anos [que tem o LOAS]. Eu consegui e depois eu perdi, tomaram... Eu tive que entrar com o advogado, foi até o Lar das Moças Cegas que me arrumou este advogado... Depois de muito tempo... [...] É um salário mínimo, só... Não tem décimo terceiro, não tem nada. Ele só aumenta quando tem de aumentar, quando o salário aumenta. Se não, não aumenta... [...] É uma batalha. O médico chegou a ponto de falar assim: 'Você não tem necessidade disso, você pode muito bem trabalhar... Por que você anda atrás de um salário?'. Eu falei: 'Realmente, eu posso trabalhar, não nego pro senhor não... Eu já trabalhei até em casa de família... Agora o senhor precisa ver se a sociedade dá emprego...'. [...] Só quando você tem assim, vamos dizer, uma pessoa que esteja a fim de ajudar...". [Fátima].

Fica explícita a dificuldade de conseguir acesso a oportunidades de emprego. No relato de Fátima acima, também está presente a falta de formação para as vagas que aparecem, assim como já trazido por Ricardo.

Ainda sobre o acesso, Ricardo aborda com muita ênfase os aspectos relacionados à acessibilidade urbana e arquitetônica. A acessibilidade arquitetônica das empresas pelas quais passou são motivo de preocupação e dificuldade para ele. Os ambientes não estão adaptados: alturas dos bebedouros, presença de escadas e falta de elevador, degraus e desníveis no chão, falta de rampas, largura das portas são alguns dos exemplos. E foi ele quem mobilizou para as mudanças, falando com os superiores e com os colegas, e também escrevendo cartas solicitando as transformações no espaço.

"Então, falta de acessibilidade é uma coisa que sempre existiu; na primeira empresa, portas todas automáticas e queria ir no banheiro, era rapidinho. Mesmo a condição de ficar na cadeira, a bexiga fica pressionada e você tem que tomar líquido, pra você não ter infecção urinária, e tinha bebedouro alto. [...] Então tem que mudar, teve que mudar. O lugar que era pra eu trabalhar, o piso tinha dois degraus. Primeiro dia de trabalho, chego eu lá, aprovado, 
crachazinho, vai lá. Chegando lá, cartão magnético, a parte chata: fui entrando e dois degraus. Eu falei: Hã!!!! Que que é isso gente? Aí voltei, né. E já tava dando a hora, comecei a chamar o pessoal, aí foram ver: Ah! Tem dois degraus! [...] Não, mas os amigos, colegas, companheirismo... Companheirismo tá lá sempre, mas eu não aceitei e até saí de lá da empresa. Fiz uma carta pra gerência: Oh, tô saindo, tô insatisfeito por isso, demorou muito." [Ricardo].

"Outra coisa: por que tem restaurante que não tem rampa? Só come gente que anda? Eu não sei se você já reparou, mas tem lugar que não tem... Eu um bar comum então, pior ainda. Tem que fazer mais rampa, aquelas rampas de rua, aquilo lá é tão legal, porque aí a gente já procura atravessar ali." [Ângela].

Ângela ressalta as condições de acessibilidade dos sanitários dos espaços e órgãos públicos; menciona que quando há aqueles reservados para pessoas com deficiência, acabam sendo usados por todos e, além disso, muitas vezes estão em condições precárias de higiene. Para ela, que utiliza sonda para controle da urina, o uso do banheiro é primordial quando está fora do ambiente doméstico.

\footnotetext{
"Banheiro é uma coisa que deveria ser reservada. Às vezes você vai usar um banheiro, lá com cadeira de rodas, tem gente usando. Entra um cadeirante, eu já vi, muitas vezes... Eu não uso, mesmo eu com bengala, falo: Não é justo... Se eu preciso, o outro também precisa... Se eu estou apertada, outro também está apertado... Eu penso assim... E, não é todo lugar que tem também não; já aconteceu de eu ir em mercados e ver a pessoa, estar ali, não ter, estar tentando passar com a cadeira na porta. E é uma coisa que devia ter, ter bastante, ter em todo lugar... Eu acho que o nosso país não está preparado ainda pros deficientes físicos. Não tá! E tem muito, muito... Pensa que não tem, mas tem bastante..." [Ângela].
}

A circulação na cidade também é uma grande dificuldade. São vários os aspectos relatados pelos sujeitos entrevistados: as calçadas sujas, esburacadas 
e em desnível, a falta de rampas, a falta de sinalização apropriada para as pessoas com as diversas deficiências, a existência de poucos ônibus adaptados (entre outras dificuldades com o transporte público), o tempo dos semáforos. A condição ruim potencializa a dependência das pessoas com deficiência, conforme o conceito de desvantagem trabalhado por Amiralian et al. ${ }^{14}$ : desvantagem é o prejuízo para o indivíduo, resultante de uma deficiência ou de uma incapacidade, que limita ou impede o desempenho de papéis de acordo com a idade, sexo, fatores sociais e culturais. A desvantagem caracteriza-se como uma discordância entre a capacidade individual de realização e as expectativas do indivíduo ou do seu grupo social, representando a socialização da deficiência.

Ângela comenta as diferenças entre os bairros da sua própria cidade, São Paulo, falando especialmente sobre as condições da região em que vive:

"[A principal dificuldade é] Andar na rua, principalmente. Porque se eu esbarro nos outros, às vezes eu caio, e não posso; por isso, eu não posso mais sair sozinha na rua, ninguém deixa. Pegar um ônibus... Isso é terrível! [...] Mas também, se a gente anda na rua, tem umas calçadas horrorosas. Eu acho legal mesmo no Hospital das Clínicas, porque tem aquele corrimão. Eu acho muito bacana. Quantas vezes eu já utilizei aquilo ali! Claro, todo mundo pega, mas eu lavo as mãos, não me importo. Aquele elevador pra pegar ônibus, muito legal... Lá, até o horário que eu vou, eles respeitam; geralmente são gente que precisa mesmo. Acho que devia ter mais dessas coisas pra facilitar a vida da gente. Seria muito bom... Tem lugar que não tem nem aquela rampinha, tem semáforo que não tem aquela rampinha pra gente descer, aí você tem que pôr o pé lá, depois o outro, o semáforo já está fechando... É legal quando tem aquela rampinha... Mas é pouco; em bairro não tem, em vila você não acha isso não. A minha, Estrada de Itapecerica, tem que atravessar aquela estrada e o farol lá é rapidinho; eles não respeitam não, principalmente motoqueiro. Vira e mexe acontece acidente!... E tem aqueles degraus de paralelepípedo, é horrível!" [Ângela]. 
Se nas regiões centrais a condição é ruim e as adaptações estão presentes em apenas alguns espaços, nos bairros mais afastados, na periferia da cidade, esta condição é ainda pior. Fátima menciona as diferenças entre as cidades da Baixada Santista (região onde mora), na questão da acessibilidade arquitetônica, bem como as dificuldades vivenciadas pelas pessoas com deficiência:

"[A cidade de Santos] Das que eu já conheci, é a melhor, mesmo complicada. Mesmo com as calçadas quebradas, mesmo a moça que tem dificuldade em atravessar... Pra mim - e todos os deficientes visuais falam - é a cidade melhor para um deficiente visual. É Santos... Humaitá é péssimo... Cubatão é péssimo... São Vicente é uma desgraça... O lugarzinho terrível pra deficiente visual andar... Eles não tem uma linha guia em nada, é tudo no meio da rua. A linha guia das calçadas são uns sacos enormes, cheio de pedras, cheio de árvore nas calçadas, cheio de entulho. E aqui não. Aqui é uma coisa que é quebrado, mas tem a parede pra proteger... Sossegado... Sossegado... Dos lugares mesmo, a que eu achei pior foi São Vicente. Todo mundo fala dessa cidade... É a primeira cidade da baixada santista, já devia estar bem adiantado, mas tá bem atrasado..." [Fátima].

Ricardo, como cadeirante, também tem muitas dificuldades na circulação pela cidade, relatando muitas barreiras arquitetônicas, tanto para ir ao trabalho, quanto para passear.

"Eu saio, vou pra shopping. Eu gosto de natureza, de passear, mas até mesmo a própria condição não permite muito ir pra parque. Aqui o Villa Lobos é bonito pra caramba, mas nunca me atrevi a ir de ônibus; sempre com alguém de carro. [...] Então esse trajeto daqui da minha casa, até lá [ponto de ônibus] dá uns dez minutinhos, porque a calçada não ajuda. E aí, muitas vezes, tem que ir por asfalto e tem que ter atenção. Madrugada é pior ainda, porque vem o pessoal da balada e o cara já encosta ali pra ir na padaria com tudo, não liga pra sinalizar nada. Tem outra dificuldade também que é o 
pessoal que pega esses cachorros bravos pra passear, e eles soltam, imaginam que não tem ninguém na rua. Já aconteceu do motorista estar me puxando naquela rampinha do ônibus adaptado, e veio o cachorro e: Au! Fora a sujeira." [Ricardo].

A fim de facilitar a circulação das pessoas com deficiência pela cidade, em uma estratégia para equiparação de oportunidades, algumas leis foram criadas como a gratuidade no transporte público municipal, intermunicipal e interestadual. Rubens e Fátima ampliaram seu acesso pela cidade (e pelo país) através do recurso.

"[A carteirinha do ônibus] Tá aqui, é bom! Ela [a irmã] arrumou pra mim. Não faz [tempo] não, faz dois, três meses só. Vale até dois mil e quatorze, dura... $E$ melhorou, ajuda na passagem. Muito barato! [Antes eu ficava mais em casa], e andava mais - mil e quinhentos metros a pé..." [Rubens].

"Agora eu vou pra todo lugar... Inclusive agora em julho eu vou pra Bahia ver o meu pai; já fui duas vezes sozinha, porque - graças a Deus - o governo liberou o passe livre, e eu consegui o passe. Então todo ano eu vou ver o meu pai. Este ano eu não fui porque eu tinha umas coisas, tinha umas prestações e eu tinha que esperar um pouco, mas agora em julho eu vou ver o meu pai. E essa é a minha história..." [Fátima].

A prefeitura de São Paulo disponibiliza o Serviço de Atendimento Especial (ATENDE), que é uma modalidade de transporte gratuito, porta a porta, destinado às pessoas com deficiência física severa, com alto grau de severidade e dependência, impossibilitadas de utilizar outros meios de transporte público. Foi criado por meio do decreto n⿳36.071 de 09 de maio de $1996^{61}$. Há uma série de critérios para consegui-lo, e são muitos os relatos de dificuldade com este serviço. Mesmo para Ricardo, que vai com o ATENDE todos os dias para o trabalho, as dificuldades enumeradas são grandes. Os ônibus comuns adaptados 
são poucos, em poucos horários e somente disponibilizados em algumas linhas da capital.

"Hoje, pra trabalho, eu tenho o serviço ATENDE, que é uma luta nossa, que é uma coisa que a gente sempre tá de olho, tomando conta mesmo. De uma certa forma, a gente toma conta desse serviço ATENDE, porque foi uma coisa que, num primeiro momento, há dez anos, doze anos, foi colocado e até hoje é um decreto. Sendo um decreto, não é lei. Se chegar alguém aí e falar: Num dá pra gente cumprir, então... Mas nós estamos caminhando pra transformar em lei... Então, no dia-a-dia, pra trabalho, eu tenho. Agora, pra sair, não. Pra sair é ônibus. É adaptado, que também a gente cobra muito, cobra horário e cobra se não tá na linha... Não tem outro não, não dá pra correr não e é muita dificuldade mesmo. [...] Os horários do ônibus [adaptado] são determinados pela empresa, a SPTrans. Então, por mais que a gente tente mudar, a gente não consegue muito não. É aquele horário lá... Por isso que entra essa questão de eu ter que acordar às quatro e meia da manhã, ou quatro horas, porque não consigo - pela minha ansiedade até - não consigo fazer várias coisas ao mesmo tempo e correndo. E eu tenho medo de queda..." [Ricardo].

"Os deficientes físicos têm bastante, só que é mais escondido. Acho que não sai, não mostra, só por causa dessas dificuldades. Ônibus, são quatro cadeirinhas ali, pronto. Sentou, sentou... De manhã, é terrível! E não são todos que tem um piso baixo pra entrar com a cadeira de rodas. Se você precisa do ATENDE, você demora, demora, demora. Ele é muito bom, mas... Já pedi, mas não consegui. É uma coisa muito, muito, muito demorada. Tanto é que a assistente social falou: Olha, se for pedir ATENDE, você vai acabar o tratamento e não vai conseguir - ATENDE... Eu acho que tem pouco, e é um transporte ótimo, porque ele já abaixa a cadeira de roda, tem aquele espaço grande, não judia. [...] [As pessoas com deficiência precisam de] Meios para locomover... Esse ATENDE é uma vergonha; desculpe eu falar, mas é uma vergonha. Foi que nem a assistência social falou pra mim: Olha, você vai acabar o tratamento, o ATENDE não vai ainda te chamar..., de tão demorado que é. É porque tem muita gente..." [Ângela]. 
Continuando no tema circulação na cidade, há aspectos que estão para além da acessibilidade arquitetônica: barreiras atitudinais. As barreiras atitudinais potencializam as dificuldades impostas pelas barreiras arquitetônicas e, por conseqüência, $o$ isolamento. Alguns relatos mencionam a falta de compreensão e o preconceito por parte dos motoristas de ônibus, que discriminam pessoas com deficiência (e também idosos). A fala do Sr. Jair é um exemplo:

"Mas já vi reclamação... Tem outro colega meu também que ele é [deficiente], que pra subir no ônibus usa muleta. Ele tem dificuldade, às vezes tem motorista que vai lá, tirar ele da cadeira, dá a mão, tem motorista que faz isso. Mas tem outros que não, se puder, quer que o cara entra rápido e tchum. Às vezes, vira a cara pro lado, isso aí já aconteceu comigo nas Clínicas. De eu dar o sinal [pro ônibus] e o cara... Eu acho que o cara me conhece, sabe que eu entro pela frente, não paga a passagem, eles não gostam muito de pegar as pessoas deficientes, as pessoas de idade. Acho que eles pensam que não poderá acontecer isso um dia com ele, ficar velho ou sofrer um acidente, ou da família deles... Maldade, eu acho que maldade... Quando é um velhinho no ponto de ônibus, eles odeiam parar para pessoas de idade, tem muito motorista que odeia, passa direto, vira pro lado assim e faz, finge que não está vendo... Mas comigo foi uma vez só..." [Sr.Jair].

Fátima enfrenta estas situações de preconceito a partir da compreensão de seus direitos como cidadã. Ela conta como reagiu ao sofrer discriminação por um motorista e um cobrador:

"Porque o deficiente entra e sai pela frente... Naquela época ainda tinha cobrador, então eu entrei e sentei... O cobrador entrou, ficou ali e depois o motorista entrou, ele olhou assim pra mim e falou: 'Escuta! E isso aí, quem cuida disso aí?'. O cobrador falou assim: 'Ah eu não sei! 
Eu cheguei e já achei isso aí...'. Eu falei: 'Escuta, vocês estão falando de mim?'. Ficaram quietos, eu falei: 'Olha, é o seguinte, eu não sou isso... Eu vou mostrar minha identidade pra vocês... Eu tenho 35 anos, me chamo Fátima... Então eu não sou isso... Eu sou gente, e uma cidadã igual a vocês... E vocês estão fazendo isso por quê? Porque eu entrei e não paguei? Eu entro e não pago porque é lei... Deficiente visual ou qualquer tipo de deficiência, a gente não paga, você sabe muito bem disso... Então eu não to tirando nada de vocês, eu tô viajando no que é meu... E eu pago! Porque de qualquer maneira eu moro de aluguel e pago imposto da casa do dono, que não era pra mim pagar... Então quem paga sou eu... Então eu não sou isso!'. Eles ficaram quietinhos, não falaram nada, nada..." [Fátima].

Para sair de casa, Ricardo tem um planejamento detalhado, que engloba, além das suas atividades de cuidado pessoal, um estudo sobre o transporte do local que vai, as condições de acessibilidade da região, as possibilidades de ir ou não - isto é, todos os aspectos mencionados anteriormente. Já recusou propostas de emprego por este motivo, e, entre outras passagens, conta sobre uma entrevista de emprego que foi e as dificuldades vividas:

"Antes de eu entrar nessa oportunidade agora que eu tô, no CAT, eu tive que pagar taxi. Foi na Lapa mesmo! Numa empresa lá, me ligaram: Oh, uma oportunidade assim, assado... É um setor novo, você não vai fazer mais telemarketing... Ela até me falou: Tem uma estação de trem pertinho... Fui aqui, me meti a ir em Osasco, e aí chega e não era adaptado o negócio e tem que pedir ajuda; os guardas ajudam até certo ponto porque eles não podem pegar lá na rua, porque foge do local de trabalho deles e não têm permissão. $E$ foi isso que aconteceu. Falei: Caramba! Pensei que parava no nível da rua! Essa empresa é aqui do outro lado, a gente vai ajudar você a subir, mas só que tem uma coisa: a passarela que tá de frente a empresa, a gente não pode descer você lá, porque aí foge do nosso local de trabalho... Mas dá tempo, oh se dá tempo! Você veio com uma antecedência monstruosa. Aí então eles me ajudaram a subir, chegou lá 
em cima lá e tal, o cara foi lá pedir permissão e: Tudo bem, vocês podem ir, falou o chefão, mas aí vocês deixam os equipamentos de segurança de vocês aqui e se acontecer alguma coisa aqui, vocês vão ser responsáveis, porque vocês estão abandonando o posto... Você vê que tem gente boa, mas o desespero começou a bater e aí falei: Ah, não! Um taxi, um taxi... Moço por quanto você me leva lá? Peguei a bolsinha que fica embaixo, dei as moedas: Putz, tem que dar! E deu, mas eu já gastei vinte e cinco e, pra voltar, eu vou ter que pagar mais vinte e cinco; cinquentinha todo dia, até eu conseguir o ATENDE (que é no mínimo um mês, dois), é muita grana! Então, pra eu não perder essa entrevista, tive que pagar esse taxi. E tive que recuar, e é muito boa, na Lapa, na cara de casa, e por mais difícil que seja, mas é mais perto. Eu vejo muita dificuldade assim em me locomover mesmo, acho que se tivesse um transporte meu mesmo seria muito mais independente, mas daí sou bem consciente: Se eu posso, eu posso! Se eu não posso, não posso!" [Ricardo].

E, além do estudo, trabalho, transporte, oportunidades, Ângela destaca que as pessoas com deficiência precisam de espaços e oportunidades de lazer e convivência.

"Porque acham que a gente tem essa doença e tem que ficar em casa. Não é isso! Agora, na rua tem muita coisa ainda pra arrumar pra gente. Não sei se é arrumar, mas fazer com que as pessoas encarem melhor, olhem com outro jeito... Eu acho que não é só com deficiente físico não, é com idoso também; eles passam um mau pedaço. Eu queria que tivessem mais coisas alegres pra gente fazer. Não tem baile da terceira idade? Eu queria isso, um grupo, vai fazer não sei o quê... Eu acho que tinha que ter um negócio desses pros deficientes físicos, que seja pros cegos, pro paralítico, que tivesse... Mas tinha que ter, porque tem tanta coisa pra tanta gente... Uns encontros de vez em quando... Até aquele que pode sair sozinho, ia sair, e alguém ia com acompanhante. Eu acho que tinha que ter isso. Isso faz falta! Isso eu acho que não tem mesmo... Eu não conheço..." [Ângela]. 
Diante desta dificuldade de acesso a espaços de cultura e lazer (quer seja pelas barreiras arquitetônicas, transporte, barreiras atitudinais), os serviços e instituições de saúde e/ou educação acabam funcionando como espaços de convivência e lazer, específicas para aquela população com determinada deficiência, e - portanto - segregada. É o caso de Fátima, que assim como outros colegas de instituição, está há anos no mesmo centro de educação e reabilitação; participa de muitas atividades, muitas vezes até escolhidas pela própria equipe.

\begin{abstract}
"Ao chegar, sou recebida pela assistente social, que vai atrás da 'aluna'. Aguardo e observo. Não sou apresentada formalmente à instituição, mas parece ser uma mistura de centro de reabilitação, convivência e escola. No andar em que estou, há adultos com deficiência visual circulando. Enquanto aguardo, na sala da coordenação, um aluno vem conversar com a coordenadora sobre seus horários.

[As cenas que vejo causam estranhamento: adultos, acima de 30 ou 40 anos, vestidos como alunos de ensino fundamental, com o típico uniforme das escolas brasileiras (calça de elanca azul e camiseta com o símbolo da prefeitura e da instituição), freqüentando o que parecem ser salas de aula. Que lugar ocupam estas pessoas? Que lugar ocupa esta instituição? Remeto-me a última entrevista que realizei antes desta - com Ângela - e minhas reflexões sobre a falta de espaços de convivência, trabalho, lazer. As pessoas com deficiência parecem naquela cena - continuar ocupando o lugar da criança, protegida e tutelada em uma instituição]." [Trecho do diário de campo].
\end{abstract}

Fátima menciona o quanto este uso da instituição alimenta uma configuração de filas, lista de espera e falta de acesso a outras pessoas com deficiência:

"Eu acho que este ano agora já deve estar com seus trezentos alunos; se não tiver, está chegando. E tem uma 
lista de espera que não tem fim... A gente vem e não quer sair pelo seguinte: tem muito companheirismo aqui, conhecemos muitas pessoas legais. [...] Então, você vai criando um vínculo como família... $\mathrm{E}$, além disso, os cursos que tem aqui... Que é muito importante! Por exemplo, os cursos que eu faço: é muito importante para minha saúde. Eu tenho vários problemas de saúde, e preciso de exercícios. E aí o pessoal que vem não quer sair... Então vai crescendo aquela lista... Porque na baixada santista tem tido muitos deficientes visuais e só tem essa escola aqui..." [Fátima].

É possível observar ainda que muitas das dificuldades vivenciadas e relatadas pelos entrevistados estão para além da deficiência, engendradas nas questões macro-sociais, e que envolvem muitos brasileiros com ou sem deficiência. Ricardo retoma esta questão, e também menciona o fato da deficiência poder potencializar as dificuldades, conforme trabalhado anteriormente.

"... E de ver que a coisa tá tão difícil, tão sofrida, pra maioria das pessoas, e o pessoal que tem uma deficiência? Aí putz, vai ser pior ainda. É a realidade, é isso mesmo, vou tocando cara. Vou tocando e aí eu tô deixando o barco correr..." [Ricardo].

Os direitos, assegurados pela constituição e ideal de luta do movimento social das pessoas com deficiência desde sua origem, acabam sendo compreendidos enquanto um "favor" ou uma questão de sorte para a pessoa. Pode prevalecer a idéia de que o uso do transporte público, a circulação na cidade, a utilização dos espaços, a aposentadoria/auxílio-doença, as possibilidades de inclusão no trabalho, a utilização dos serviços de saúde não são direitos, conquistados e garantidos, mas sim um "favor", já que o acesso cidadão é muito difícil. Um exemplo claro é na história de Ricardo, onde a busca e a filiação ao movimento político organizado de pessoas com deficiência foi 
motivado pela necessidade individual de encontrar caminhos para o acesso a bens e serviços.

\begin{abstract}
"[Para entrar no conselho] Foi a 'precisão' mesmo: comecei a precisar. Não tinha meio de ter um plano de saúde, por conta de fazer artesanato, então não tinha muito acesso. Então falei: Poxa! E aí? E agora? Aí comecei a me empenhar e entrar no movimento de pessoas com deficiência, do conselho municipal da pessoa com deficiência, que ali você tem vários contatos, eu comecei aqueles debates todos, e eu falei que o nosso segmento não tem tanta representação assim. [...] [Sobre o movimento de pessoas com deficiência] Eu vou falar por mim: trouxe saber, conhecimento, saber o caminho a ser trilhado, não ficar vagando sem informações. Você tem mais contato lá dentro, você sabe quem é o coordenador de saúde, que cuida ali do bairro, você conhece o gerente do seu postinho, a assistente social do seu postinho, você sabe e então você tem acesso. Então isso aí me abriu, lógico, o caminho de ver mesmo, de procurar as coisas, saber os caminhos certos..." [Ricardo].
\end{abstract}

\title{
5.3.1 - Acesso e saúde
}

Aspectos específicos sobre o tema da saúde já foram abordados, mas é necessário o aprofundamento em alguns tópicos, que serão aqui apresentados. O acesso e os direitos relacionados às pessoas com deficiência estão intimamente ligados às questões que envolvem o cuidado em saúde e o uso dos serviços de saúde. São diversos os percursos no sistema de saúde relatados pelos usuários, envolvendo recursos próprios e do contexto familiar e social para enfrentamento da condição de deficiência.

Segundo Almeida et $a^{2}{ }^{2}$, corroborado por Othero e Dalmaso ${ }^{58}$, no âmbito das práticas e ações em saúde da pessoa com deficiência, a filantropia ainda permanece como referência de cuidados, acima dos serviços públicos. Mesmo com a conquista de direitos, alavancada pelo movimento social das pessoas com 
deficiência nas décadas de 1970 e 1980, o acesso aos serviços públicos continua difícil e relatos de experiências negativas com os programas e recursos existentes são constantes. De acordo com Othero e Dalmaso ${ }^{58}$, a família e uma pequena rede de apoio agregada acabam sendo as principais fontes de cuidados às pessoas com deficiência, destacando que não existem políticas ou ações mais amplas voltadas para o apoio ao familiar e construção/consolidação de redes de apoio.

Nas trajetórias relatadas pelos sujeitos entrevistados, o acesso aos serviços é questão crucial. Segundo Lacerda e Valla ${ }^{62}$, este é um aspecto crítico da área da saúde, sob diferentes nuances. Para os autores, na procura pelo atendimento há dificuldades, uma vez que a localização geográfica e a distribuição dos serviços estão em áreas mais centrais (fazendo com que pessoas que moram em áreas mais distantes tenham dificuldades) e há uma carência no transporte público (além do valor das tarifas), aspectos dificultados para as pessoas com deficiência devido as péssimas condições urbanas de acessibilidade. No âmbito da utilização dos serviços, a organização do atendimento, a disponibilidade dos profissionais, a capacidade dos serviços em absorver a população são outros fatores que dificultam este acesso.

As filas, a demora entre as consultas, a superlotação, o número de profissionais aquém do necessário, a sobrecarga de trabalho, os baixos salários são aspectos discutidos pelos autores. Ricardo menciona a grande fila de espera para certos exames como uma dificuldade no âmbito do sistema de saúde; Sr. Jair menciona a demora para ser atendido, mesmo quando já há a consulta agendada, potencializando as tensões e angústias oriundas do estar em tratamento.

"Nesses movimentos, eu via uma coisa que me assustava muito, que é fila de espera pra certos exames aí de seis 
meses, sete meses. [...] A saúde falta mesmo, e eu tenho mesmo essa carência mesmo, e sou chateado com isso, mas procuro não pensar. Eu já sou muito encanado, e se eu ficar mais ainda, aí eu não vivo. Então, deixa pra lá..." [Ricardo].

"O meu tratamento está bom, mas o que eu gostaria assim, é de ser atendido o mais rápido possível, porque ali quando você entra lá dá um... Quanto menos tempo você ficar lá dentro, pra mim era melhor... [...] Quando fica lá, que chama lá pra dentro, demora... parece que você vai... um estado de nervo fica maior... [...] Nesses hospitais, você já vai apreensivo, você já dorme pensando: 'Ô amanhã tenho que ir no médico... Você vai com tudo aquilo...'. Aí quando chega lá que demora pra atender, você vai ficando mais chateado, nervoso, invocado, então... [...] Você fica sempre tenso..." [Sr. Jair].

A necessidade de mais informações em saúde, relacionadas à prevenção da deficiência e à prevenção de incapacidades, é colocada como um aspecto de fundamental importância. Sr. Jair chama a atenção para as campanhas em saúde e a necessidade de maior veiculação de informações, atribuindo a elas o papel de divulgar os possíveis agravos à saúde e também estratégias de prevenção e mutirões diagnósticos.

No caso do Sr.Jair, Fátima e Rubens, se o diagnóstico e o início do tratamento tivessem sido realizados antes, as condições de incapacidade atuais seriam diferentes, o que - potencialmente - poderia trazer ampliações nas suas condições de autonomia e independência (tão valorizadas, como já discutido). A isto, muitos aspectos estão relacionados: acesso aos serviços de saúde, informação e conhecimento sobre a deficiência, sintomas e causas, mecanismos de enfrentamento pessoais e familiares frente às situações de adoecimento, entre outros.

"Diz que é hereditário. Eu tenho um primo que ficou cego também. No Piauí, eu tenho uma tia também que morreu 
sem visão. É o tal do glaucoma também. Eu fui herdeiro dessa porcaria. E eu tenho uma irmã também que diz que está com glaucoma, só que quando ela descobriu que estavam embaçadas as vistas, ela foi e começou a usar colírio, e então a pressão não subiu. Nunca tinha ouvido falar, nem sabia disso, nunca passei em oftalmo. Se eu tivesse... [...] Só quando apareceu esse embaçamento na vista que eu fui procurar o médico, do contrário eu lá sabia que existia isso aí? Nunca tinha ouvido falar de glaucoma; ouvi falar depois que apareceu em mim." [Sr.Jair].

"Ele já falou pro meu irmão e minha cunhada que não tinha chance e que tinha que tirar: 'Olha! É glaucoma congênito, muito forte, não tem o menor jeito... E tinha! Se ela tivesse vindo pequenininha assim que descobriram, que ela não enxergava...'. E quando a minha mãe percebeu que eu não enxergava, eu tava com seis meses de idade... Eu fiquei muito triste, mas mesmo assim eu fiquei alegre porque ele falou: 'Olha, a gente vai operar'. Como que já sabia mesmo que ia tirar, eu fiquei alegre, falei: 'Pelo menos da dor eu vou ficar livre, graças a Deus..." [Fátima].

Segundo dados publicados no documento "Atenção à Pessoa Portadora de Deficiência no Sistema Único de Saúde - Planejamento e Organização de Serviços" (1993), as ações de prevenção nos níveis primário e secundário, se executadas de maneira apropriada e eficaz, possibilitam a diminuição de incidência de incapacidades em 50\% nos países em desenvolvimento. Se restritas somente ao nível secundário, as ações preventivas possibilitam reduzir a ocorrência de deficiências em torno de $20 \%{ }^{4}$.

Outro aspecto fundamental relacionado ao acesso à saúde é a dispensação de equipamentos de tecnologia assistiva e dispositivos de auxílio, além de medicamentos. Sr. Jair ressalta que os medicamentos que utiliza são muito caros, daí a importância de manter o atendimento constante, para conseguir as receitas e as medicações. A dispensação de medicamentos é fundamental para a saúde; e, portanto, para as pessoas com deficiência. 
A concessão de órteses e próteses é regulamentada pelas Portarias MS/SAS n. 116 e 146, de 1993, e também a Portaria MS/SAS n. 388/199924. As primeiras estabelecem todo o fluxo de concessão de órteses e próteses (e também bolsas de colostomia) em nível ambulatorial, além de confecção, adaptação e treinamento do paciente quanto a seu uso, as unidades a que compete, e as atribuições dos gestores estudais e municipais. A portaria n.388 estabelece, principalmente, as normas básicas de confecção das órteses ortopédicas.

O decreto n.3298/1999 descreve os demais equipamentos de ajudas técnicas a serem concedidos às pessoas com deficiência, incluindo-se além das órteses, próteses e bolsas de colostomia: equipamentos adaptados; elementos de mobilidade, higiene e cuidado pessoal; dispositivos para facilitar a comunicação; material pedagógico e adaptações ambientais.

A lista das tecnologias assistivas a serem concedidas pelo SUS é grande, porém algumas dificuldades no acesso a elas foram relatadas pelos entrevistados; considerando-se ainda que, além do equipamento propriamente dito, há casos que exigem manutenção e adaptações constantes. Segundo Bernardes et al. ${ }^{3}$, a política de saúde das pessoas com deficiência será introduzida no Pacto pela Saúde (instrumento de priorização e pactuação/negociação de recursos no âmbito tripartite); e, segundo os autores, foi constatada uma demanda reprimida de cerca de 1.042 .000 pessoas por concessão de órteses e próteses, sendo esta ação considerada prioritária a fazer parte do programa, com recursos adicionais a serem destinados para tal fim até 2010.

"É caro [o aparelho auditivo]. Hoje deve tá uns sei mil... Muito caro... Não dá... Eu comprei porque eu saí do banco, eu tinha condição de comprar. No SUS, tinha o CEMA, aquele hospital na Mooca. Ele tava com uma cota 
super grande de aparelho e não tinha procura; a gente foi espalhando, não só daqui, mas os outros lugares também: minha irmã, a Eliane, que não tinha condição, foi lá e eles deram lá. Não são aparelhos assim, maravilhosos, mas pra quem precisa dá certo. Mas só que agora eles só tão atendendo a região; então eu, por exemplo, vou pra lá, eles não atendem. Só quem é da região, porque encheu de gente. Eu não sei mais nenhum outro lugar que disponibiliza aparelho. É muito caro! Hoje tá uns seis mil, seis e pouco. É caro! Quem vai botar dois... Eu não tenho dinheiro, só vou comprar porque eu vou receber uma grana agora do banco, aí eu vou trocar. Porque ele também tá começando a pipocar; mesmo que eu não tivesse esse outro valor chegando, eu teria que me virar e pagar, porque eu preciso dele pra trabalhar. Às vezes você precisa fazer manutenção, ele começa a dar umas apagadas. Tá com pilha nova e ele não faz barulho nenhum, você não ouve como se tivesse sem pilha; e a manutenção é super cara, a manutenção é quinhentos reais. É muito caro. Essa pilha dura uma semana, custa doze reais quatro pilhas. [...] É caro e, no verão, ela vai embora mais cedo. O desgaste dela é maior na luz solar. Então, quando eu tô em casa, muitas vezes eu tiro o aparelho e deixo aberto pra economizar pilhar. Todos esses detalhes..." [Cristina].

"Até que o pessoal da UNIFESP prescreveu uma cadeira, assim assado, por SUS. Eu bati, bati, bati no SUS... Eu fiquei sabendo que ia sair a cadeira, mas não era desse jeito, Ah, se não é pra sair desse jeito... Saiu, mas eu doei; eu peguei e doei. Alguém aparece, sempre os outros sabem que tem alguém que tá precisando, aí doei a cadeira e consegui essa aí. E o pouco que eu posso, eu invisto nela. Sei que eu preciso de uma melhor, mas é essa que é possível agora no momento. E não tenho capacidade de ir na Reatech ou comprar ou levar a cadeira. [...] Eu fui lá, vi a cadeira, a cadeira tava em torno de cinco mil reais... Só posso comprar essa daqui, que um par de rodas aí, que é um salário mínimo e meio... [...] Então assim, eu vejo que preciso de uma cadeira melhor, preciso ter um acesso melhor ao sistema de saúde, a uma hidroterapia, a um acompanhamento psicológico até. Mas, não tenho, não tenho. Vou vivendo assim..." [Ricardo]. 
"... Aí a gente foi batalhar pelas próteses. Eu passei sete meses aqui, até sarar. Fui batalhar pelas próteses, porque era o SUS que ia dar e realmente foi ele quem deu. Fo muita batalha, porque era muito caro naquela época; era não, é. Os custos vão subindo cada vez mais. [...] Eles demoraram a mandar... [...] Olha, eu operei em janeiro e fui colocar minhas próteses em abril... Era para colocar com um mês. [...] Elas são de acrílico e, de seus em seis meses tem que polir. A gente vai polir em São Paulo. A última vez que eu poli, já tem mais de dois anos; são trinta reais cada uma prótese para polir. Tem que pagar isso também... [...] Quando eu fui trocar agora, eu não consegui. Foi uma pessoa que me deu. [...] Mas foi ela quem deu seiscentos reais pra mim e eu troquei. Eu não posso comprar nenhuma... Eu ganho o benefício do LOAS, que é pra mim pagar meu aluguel. Fica super difícil trocar..." [Fátima].

Além dos dispositivos de auxílio, mais comumente associados à questão da deficiência, como bengalas, cadeiras de rodas, cadeiras de banhos, órteses e próteses, por exemplo, há outra gama de equipamentos relacionados aos cuidados necessários. Ângela relata a necessidade do uso de uma sonda vesical específica e outros materiais para minimizar a incidência de infecções urinárias.

\footnotetext{
"O Dr. Miguel falou que tinha uma ONG, que tinha que entrar com um processo pra pegar essa sonda, porque eu estava pegando muita infecção. Chegava a ficar internada por causa da infecção. Ele falou que era pra mim usar outro tipo de sonda. A minha irmã foi lá, eu fui com ela, a moça explicou, levamos os documentos, tiramos xerox, tudo isso. Não demorou muito... Eu tenho uma sorte! Não demorou muito e eu fui chamada. O posto de lá da prefeitura que distribui os medicamentos caros, e eu pego o coletor, o modess e a sonda..." [Ângela].
}

Como foi possível discutir, há aspectos específicos relacionados ao acesso a serviços, equipamentos e cuidados em saúde. Além dos aspectos relatados, há ainda questões relacionadas ao vínculo usuário-profissional, muito relacionadas com a qualidade do cuidado em saúde, que serão discutidas posteriormente. 
Santos $^{63}$ afirma que, o entendimento do corpo com deficiência como uma manifestação da diversidade traz melhores instrumentos para o modo como a sociedade deve se organizar para garantir o direito das pessoas com deficiência, em consonância com o modelo da diversidade trazido por Palacios e Romañach ${ }^{13}$.

\section{4 - Percursos e sentidos das intervenções em saúde}

Após da discussão sobre o acesso em saúde, será feito um aprofundamento nas questões que emergiram nos dados da pesquisa sobre os percursos e os sentidos das intervenções em saúde.

O viver com deficiência traz outros conflitos peculiares à condição, como preconceito, isolamento, falta de acessibilidade, experiências sensório-motoras diversas, etc. E, assim, o apoio é indispensável a fim de ajudar o sujeito concreta e cotidianamente com as mudanças e incapacidades advindas da deficiência, e possibilitar a maior autonomia possível. Os movimentos desse viver com deficiência são próprios a cada sujeito, e são parte dos percursos que constroem no seu cuidado em saúde.

Cristina procura compensar sua perda auditiva com auxílio da visão (lendo os lábios e as pistas que a pessoa dá ao falar) e prestando mais atenção ao discurso. Mas, reage procurando evitar o contato com a deficiência: vai pouco a médicos, não faz os exames periódicos a ela indicados, entre outros exemplos. No trecho de sua fala a seguir, também é possível observar o peso do diagnóstico (e da irreversibilidade), mencionado anteriormente.

"Eu até operei a miopia pra ficar mais fácil pra mim; porque eu tinha miopia, três graus, eu falei: Se eu enxergar melhor, eu vou entender melhor... [...] Então, assim, a gente tem que lidar com as deficiências; eu acho 
que é um pouco difícil, melhor é não pensar... [...] Tem que ir no otorrino, mas eu não vou, saio fora... [...] Eu teria que fazer as benditas das audiometrias a cada seis meses, detesto fazer. Quando eu fui lá fazer o aparelho, eles tem uma fono e elas fazem também [audiometria], apesar de eu levar a minha, eles ajustam o aparelho no computador. O resultado da audiometria foi lá uma perda severa profunda bilateral... Eu não gosto de ler isso, eu não gosto nem de ver o que está escrito lá. Dá uma sensação que tô mais surda se eu ficar olhando pra aquilo. Então não fiz nenhum tipo de acompanhamento..." [Cristina].

Em outra configuração está Ângela que, apesar de um momento inicial em que esteve paralisada pela doença, conseguiu (e consegue) ir aprendendo a como lidar com as limitações que a doença vai lhe impondo, entende que não há cura, mas consegue visualizar e concretizar estratégias que facilitam seu dia-adia.

\footnotetext{
"Era pior no começo, foi bem difícil. Agora não sei se é porque eu já aprendi a usar sonda, a controlar melhor, não me cansar tanto... Eu já aprendi um monte de coisa... Foi aqui no tratamento; porque se eu ficasse só em casa, eu não ia saber dessas coisas não. Eu fazia as coisas, eu não parava, eu já acordava cansada... Um cansaço insuportável... E não é! Tem que parar, desligar... [...] Mas eu não me aborreço tanto, porque eu vejo que tem gente bem pior; mas tem hora que eu... Eu não vou falar que não me aborreço, porque eu me aborreço sim. Também não fico assim: Por que comigo? Por que comigo? Não vai me ajudar. Tem que saber lidar. E foi bem vendo como as coisas aconteciam comigo..." [Ângela].
}

A utilização dos serviços de saúde também está relacionada à história de cada um dos sujeitos, e os sentidos que construíram (e constroem) cotidianamente em seus modos de andar a vida. Para o Sr. Jair, a unidade básica de saúde e um hospital terciário são os equipamentos de referência. A 
busca por serviços devido à deficiência visual veio após a perda da visão, ainda que com sinais aparecendo anteriormente. A UBS é procurada para aspectos que - para ele - estão além da deficiência, como controle de hipertensão arterial e tratamento odontológico; o hospital é lugar de busca da cura de sua deficiência, mas com intenso sofrimento agregado, remetendo até mesmo à idéia de morte (ele troca a palavra cemitério pela palavra hospital algumas vezes).

O contato com o sofrimento na sala de espera (aliás, de longa espera e atraso) é muito angustiante também; é o contato com o sofrimento do outro, mas também o meu próprio: eu me enxergo no outro. Observa-se que o repertório narrativo do sujeito é reflexo de sua linguagem, de sua personalidade e se duas referências pessoais, e também da imagem que é criada de si próprio $^{51}$.

Ricardo, com deficiência desde a infância, sai do meio rural com a mãe para buscar tratamentos em São Paulo e vivencia longos períodos de internação, muitas cirurgias e procedimentos corretivos, o que prejudicam - no seu entendimento - seu estudo e, posteriormente as oportunidades de emprego. É ele quem decide interromper este ciclo "corretivo", e busca ampliar seus horizontes, como estudo e trabalho. Muito comum no campo da assistência a pessoas com deficiência, é uma instituição de longa permanência filantrópica que acaba sendo sua morada por muitos anos, além de espaço de convivência, estudo e tratamento.

Cristina, pelo seu próprio mecanismo de enfrentamento da deficiência, utiliza os serviços de maneira pontual, com demandas bastante específicas relacionadas à deficiência auditiva, como por exemplo, aquisição de aparelho auditivo (e, mesmo este, permeado por dificuldades, negação e conflito). Já Ângela, após movimento de paralisação inicial, é quem toma iniciativa de buscar os serviços de reabilitação e vai a diferentes especialidades, na busca do cuidado e controle de sua doença. 
Para Fátima, a busca pelo cuidado em saúde relacionado à deficiência visual veio já adulta, no Estado de São Paulo. Ela remete a isso o fato de seus pais serem simples, do meio rural, e não atentarem para os cuidados, bem como a falta de serviços especializados na sua cidade e até mesmo na capital do Estado (Salvador). Hoje, a utilização de serviços públicos se dá para os cuidados gerais em saúde, para além da deficiência: ginecologista, clínico geral, etc.

Rubens conviveu a vida toda com a deficiência auditiva, sem ter recebido ou buscado intervenções específicas. É com a aposentaria da irmã que este processo é disparado, buscando-se especialmente o aparelho auditivo. Para Rubens, neste momento da vida há um sentido especial nesta busca: o retorno ao trabalho possivelmente facilitado com uma melhor audição e melhor comunicação.

Ricardo aborda o aspecto de não se sentir acolhido pelos serviços e pelos profissionais, em relação as suas queixas e as suas demandas. A falta de suporte emocional é trazido como algo muito importante, bem como a falta de cuidados quando seu quadro clínico estabiliza e não há prognóstico de melhora.

"Tive tudo naquele primeiro momento lá, quando que acho que tinha alguma solução, eles podiam visualizar aí uma melhora. Depois daquele estágio que, acho que já deu, acho que não vai evoluir pra mais, você já perdeu tudo, as cirurgias então tal... Meio que deixaram assim, não interessa muito. Eu fiquei muito chateado aí com a $A A C D$ depois da síndrome, porque eu tinha ido, quem tem estrutura para dar um apoio psicológico, alguma coisa, era ela... E aí, ela falou: Não, nosso foco não é esse... Qual é? É criança, que a gente vê que tem um futuro, que vai ter uma evolução, agora vocês são adultos, vocês têm que voltar, vocês vão ficar na fila... Hoje eu sou uma pessoa muito ansiosa, então você vai ficar nessa ansiedade, então melhor saber que não pode contar. Sinto que poderia ser acolhido melhor, mas não é isso que a gente vê..." [Ricardo]. 
Como trabalhado ao se discutir a vivência da deficiência, receber uma notícia tão difícil de uma deficiência, condição ainda irreversível e por vezes com possibilidade de piora, é um momento muito delicado, e os profissionais precisam estar atentos à maneira de transmitir o diagnóstico e as diversas informações. Pode ser necessário repetir as informações e as orientações, bem como estar atento ao que o sujeito já sabe e o que ele quer saber. Há a necessidade de uma conversa franca, e que respeite o tempo e o universo cultural do paciente: a dor, os sintomas, a irreversibilidade, as chances de melhora com os procedimentos e cirurgias. Porém, para os entrevistados, em seus itinerários na assistência em saúde, isto parece não acontecer.

Para o Sr. Jair, em cada um destes momentos, sente-se enganado pelos profissionais que dizem que ele vai melhorar, e ele não melhora, ou que sequer acolhem suas queixas. Uma sensação de impotência e fracasso muito grande lhe consomem, pois para ele, ficou o registro da possibilidade de retorno da visão.

\footnotetext{
"Na primeira vez que me operou com o bisturi, pôs o tampão e aí eu dormi lá [no hospital]. Não via a hora dele tirar o tampão e eu voltar a enxergar. E quando ele tirou de manhã, que eu não vi nada, eu disse: Putz... Quase que eu morro, foi mesmo que levar um susto, foi o mesmo que levar uma facada, era o mesmo que levar um tiro. A ansiedade era tanta... Às vezes demora um pouquinho, um mês, vinte dias pra você ir voltando... Aí contava, eu contava os dias; passava de vinte dias, um mês, dois meses e nada... Não vai mais voltar não, não é o que o médico falou não. Ele está me enganando o fia da mãe, me enganou..." [Sr.Jair].
}

Já Ricardo opta em não acatar a decisão dos médicos que o acompanhavam, e vai em busca de uma segunda opinião, fazendo somente as cirurgias indispensáveis, pois "queria viver". No modelo hegemônico, pautado na correção e na cura, não há espaço para o viver com a deficiência. Na história de 
Ricardo, este ideal de correção fica explícito, mas também a busca de um novo referencial, pautado na diversidade e na suas próprias possibilidades e desejos:

"Minha mãe me tratava como um menino normal, porque aprontava, e depois, voltava de novo aquela rotina maçante, e cirurgias, e tinha que ficar em tração, tinha que ficar amarrado. Me lembro muito que eles tinham que me amarrar, porque eu tirei aqueles pesos. Tirei, porque doía muito, porque tinha que fazer tração. Então assim, a minha infância foi toda essa, em cirurgias, tudo. Passei toda essa dificuldade e aí chega na adolescência, lá vem a questão da escoliose, as três cirurgias na coluna e depois aquela proposta de refazer todas as cirurgias: "E você vai ficar bunitinho na cadeira, sem deformidade... E aí quem sabe você arruma alguém melhor, você não vai ter tanta dificuldade em conseguir alguém...". Foi mais ou menos isso que eu entendi. E aí não aceitei! Tudo bem, tem que fazer as da coluna, tem de qualquer jeito pra dar uma paradinha aí na escoliose, porque senão vai pressionar tudo, os seus órgãos, e vai ter problema pra respirar. Então, fiz aí as três cirurgias na coluna e dei um basta...." [Ricardo].

A leitura das necessidades dependerá do modelo (ou do "horizonte normativo", nas palavras de Ayres $^{41}$ ) que profissionais e serviços tomam como referência. Pautadas em um modelo médico, esta compreensão fica voltada ao corpo e as melhoras funcionais, enquanto capacidade de executar atividades ${ }^{1}$. Assim, quando não há mais possibilidade e/ou demanda para esta correção, não é validade a necessidade de auxílio e apoio. No modelo de reabilitação hegemônico, segundo Almeida et al. $^{22}$, os processos que envolvem o cotidiano e a vida com deficiência são pouco abordados, e a melhora do desempenho funcional é missão exclusiva. Neste modelo, as relações são pouco valorizadas pelos profissionais, ainda que consideradas importantes pelo paciente. Como já abordado, segundo Ayres $^{41}$, o horizonte normativo deste modelo é a morfofuncionalidade, e a escuta será orientada para obter dados objetivos; com isso, aspectos ligados à situação existencial do sujeito não são considerados, ou 
até mesmo entendidos como ruídos na comunicação. Para o autor, a restrição aos aspectos morfofuncionais contribui para o "não-diálogo".

Em todas as entrevistas, o profissional de saúde que conversa e orienta, que oferece espaço de escuta, e que valida as queixas apresentadas, é valorizado, como também é o vínculo que se estabelece com os profissionais. Segundo Lacerda e Valla ${ }^{62}$, a questão central da resolutividade em saúde (um dos aspectos da crise do sistema de saúde) é a relação médico-paciente.

"Na parte da saúde, dos tratamentos, seria necessário a pessoa ser bem atendida, porque desde que ele é bem atendido, ele fica mais relaxado. Não fica muito tenso. É muito bom pra qualquer tipo de deficiência, se ele está tratando da saúde, se ele é atendido com mais respeito, e com mais atenção. A pessoa se sente mais a vontade, mais compreendido. [...] Os médicos e as pessoas que trabalham com as pessoas que tem deficiência podem ajudar pra superar o trauma, em muitas coisas. Até os tratamentos em si. E a conversa, o diálogo, ajuda muito. Aquilo que eu te falei, quando um médico conversa com você, te atende bem... Todo tratamento que dá com as pessoas, com a pessoa conversando com você, é muito útil. E também é muito útil a assistência que dá, você se sente, se o cara atende logo... Tudo isso ajuda a superar o trauma... Ajuda muito, muito, muito mesmo." [Sr.Jair].

"O Dr.Thiago é tão bom. Nossa! Sabe quando coloca um médico que é uma luz na vida da gente? Ele orienta a gente, explica os remédios, pra que eu estou tomando. Não fico só tomando, por tomar, ele fala pra que é. [...] Eu acho que valeu, valeu muito... E não imaginava que o pessoal era tão bacana, sempre sorrindo com a gente, bem atenciosos. Para a gente que está com problema de saúde, é ótimo. Porque é terrível você encontrar cara feia ou te responder mal, o que você pergunta..." [Ângela].

O conhecimento médico, corretivo, voltado ao corpo e à funcionalidade tem fundamental importância para assistência a saúde das pessoas com deficiência, possibilitando maior independência, autonomia, qualidade de vida. Mas, como 
apresentado por diversos autores como Cecilio ${ }^{21}$, Ayres $^{41}$ e Lacerda e Valla ${ }^{62}$, os pacientes têm necessidade de se sentirem compreendidos e acolhidos, através de uma relação recíproca entre usuário, profissional e serviço de saúde.

Ao discutir os sentidos da integralidade, $\operatorname{Mattos}^{39}$ coloca a importância da abertura dos técnicos e da organização dos serviços para necessidades não diretamente ligadas às doenças, mas de maneira ampliada para contemplar o sofrimento do usuário, em um encontro intersubjetivo, em um diálogo constante para apreensão dos diferentes modos de viver e de estar no mundo. É preciso compreender a complexidade dos problemas, em seu contexto sociocultural. Assim, sua relação com os médicos que o acompanham vai sendo construída permeada por conflitos.

Cristina utiliza o relato de sua prática como profissional de saúde para deixar claro aquilo que entende como importante nesta relação profissionalusuário.

\begin{abstract}
"Porque eu tinha uns embates lá em relação ao jeito de cuidar dos pacientes; elas conversam muito e eu não gostava de conversar, eu gostava mais de ficar olhando ele [o paciente]. Eu falei: Não tenho que poupar minha perna... Tô aqui pra trabalhar, as pessoas estão lá precisando... O mínimo que eu vou fazer é colocar uma aguinha lá, com gaze, na boca dele que tá seca... Se eu não tiver nada pra fazer... [...] Aqui é um lugar que eu amo trabalhar, porque dá pra você fazer bastante coisa. Dá pra você conversar com as pessoas, dá pra você dar um alento pra pessoa, não só em relação à parte física, mas um conselho, uma palavra, porque às vezes a pessoa vem meio desesperada... Uma vez uma moça falou pra mim: Foi muito melhor aquilo que a gente conversou ali, na porta, do que você me mandar pra cirurgia... Eu não quero remédio, eu quero alguém..." [Cristina].
\end{abstract}

Cecilio $^{21}$ menciona que a criação de vínculos "(a)efetivos" entre usuários e profissionais é uma das necessidades de saúde dos sujeitos, em uma relação de 
referência e confiança. O vínculo como mais de que adscrição do usuário a um serviço ou inscrição formal em um programa, mas como uma relação contínua, pessoal e intransferível: em encontro de subjetividades. Fátima ressalta o quanto é importante o vínculo com o profissional de saúde:

"Quando era ali no SUS, ali na Alexandre Martins, eu tinha um médico, o Dr. Henrique, que era um amor de médico... Aliás, todos os meus médicos dali, todos foram uns amores... [...] Só que quando ele saiu, eu fiquei assim, igual ovelha desgarrada, eu fiquei órfã... Porque ele agora está sendo do centro de saúde, acho que lá do Guarujá... Agora, eu to com outro médico e não tem ainda o médico afetivo... Vai trocando... Então não tem aqueles médicos, você já conta seus problemas, aquele médico fixo... Não tem! É muito ruim..." [Fátima].

Ayres ${ }^{41}$ chama a atenção para a importância da abertura de um interesse autêntico em ouvir o outro, em um encontro dialógico. O autor ressalta que, para esta capacidade de ausculta e diálogo, o acolhimento é um dispositivo tecnológico bastante relevante nas propostas de humanização e cuidado em saúde; e, é no contínuo das interações entre usuários, profissionais e serviços em todas as oportunidades possíveis de escuta ao outro - que se dá o acolhimento. Isto é, o interesse e a escuta ao outro devem ser transversais aos serviços, e inerentes à prática de todos os profissionais.

No entendimento de Cristina, o cuidado e o compromisso do profissional deve ser total para com o paciente; e ela busca isso em sua trajetória de cuidados próprios, de alguma forma.

"Eu acho que seria legal um apoio, alguém pra conversar, pra falar sobre seus medos. Não é que você vai se curando, porque toda vez que eu falo dessa bendita surdez, eu fico meio entristecida, eu não gosto de falar não... Mas eu acho que, se ela fosse trabalhada lá atrás, quando eu era mais nova, talvez hoje eu não chorasse. Eu 
acho que seria interessante uma terapia, uma conversa, alguém que fala com você sobre as coisas. Eu tive um otorrino muito legal - ele era do convênio, não era do SUS, quando eu tava no banco - ele conversava bastante comigo. Uma graça ele, só que aí depois acho que ficou muito rico, ele não atendia nem mais convênio, era só particular. Ele era um cara muito legal. A gente conversava, ele conversava muito comigo, um cara muito legal... Esse médico me deu bastante apoio... O Dr.Carlos [outro médico] era legal, mas ele era muito pá, pum, tá assim, tá assado; não há espaço pra conversa." [Cristina].

Segundo Silva Jr. et al. ${ }^{64}$, a dificuldade em ouvir realmente as demandas dos pacientes e respeitar seus desejos, crenças e temores, tem sido a causa de fracassos na relação entre os profissionais de saúde e a população atendida. Os autores afirmam que os usuários, de um modo geral, não reclamam da falta de conhecimento dos profissionais, mas sim, da falta de interesse e da falta de responsabilização dos serviços por suas necessidades, sentindo-se "inseguros, desinformados, desamparados, desprotegidos, desrespeitados e desprezados" (p.125).

Em relação à escuta, um aspecto é especialmente presente na história de Rubens: sua grande dificuldade na comunicação, devido sua deficiência auditiva, parece contribuir para a não-construção de uma relação "(a)efetiva" com médicos e profissionais de saúde que o atendem. Fica clara a necessidade de adaptações para a construção desta relação vincular, a partir das deficiências e incapacidades específicas de cada sujeito. Conforme já colocado por Santos e Shiratori ${ }^{38}$, em pesquisa realizada com surdos, a comunicação foi identificada como principal necessidade específica desta população, e também a principal barreira por ela encontrada.

"Eu fui [no médico], [mas a irmã tem que ir junto]. Não é ruim... Eu fui [sozinho], [porque] tava ruim o corpo, e fui no médico, [mas demorou para o médico atender]. [...] 
Gosto [de ir no médico]. [...] [Quando estou doente, vou] no posto de saúde e no pronto socorro também... [Sempre] Acompanhado... [Os médicos] às vezes entendem [o que falo], às vezes não... [Preciso do] aparelho... Não dá não, [pra ficar sem]. Não dá mais..." [Rubens].

O desabafo e o espaço de escuta que foram propiciados pela entrevista são mencionados pelos entrevistados, que valorizaram e agradeceram a oportunidade. É importante ressaltar que todas as entrevistas realizadas foram longas, com foco no relato do sujeito e de sua história. No caso de Ângela, por exemplo, ela própria se surpreende pelo fato de ter conversado bastante e contado sua história. Que espaço de escuta realmente interessada estas pessoas tiveram? Em uma doença grave, com conseqüências radicais para a vida e o cotidiano do sujeito, que espaço houve para a conversa franca, o acolhimento, a orientação e o apoio?

A assimilação e a elaboração das mudanças, das informações e das possíveis adaptações são um processo longo e árduo, a elaboração do "trauma" (utilizando o termo citado pelo Sr. Jair e por Ricardo) - para usuários e profissionais - e é importante haver este espaço na assistência à saúde da pessoa com deficiência, sendo uma necessidade para esta população.

Retomando a criação de vínculo entre usuários e profissionais como uma das necessidades em saúde ${ }^{21}$, é preciso considerar que se estabelece um encontro intersubjetivo, em que identidades estão em contínua (re)construção a partir dele ${ }^{65}$. Porém, no caso das pessoas com deficiência, o imaginário social e cultural permeado de preconceitos e estereótipos contribui para que a atenção à saúde desta população torne-se ainda mais complexa.

No relato de Ricardo, ele conta como os profissionais de saúde não esperavam vê-lo sem acompanhante durante as consultas, e isso era motivo para estranhamento: 
"... Depois, quando eu tive que começar a buscar as coisas por mim mesmo, que eu me tornei mais fora da instituição, aí eu tive que correr por conta própria. Então, o que eu sentia é que muitas vezes eles não conseguiam enxergar: Cadê o acompanhante? Vê uma pessoa cadeirante, não só na área da saúde, mas em alguns setores falam: Ah! Mas cadê seu acompanhante? A princípio não apareciam muitos deficientes, acho que agora não sei, tô um pouquinho fora, mas acontecia disso, essa surpresa no primeiro momento." [Ricardo].

Mesmo buscando e valorizando a relação com o profissional de saúde, são diversos os relatos que minam este vínculo. No caso do Sr. Jair, por exemplo, são vários episódios trazidos: profissional que vai para palestra e o esquece na sala de atendimento, profissionais que conversam e contam piadas durante seu atendimento. Sua dor - sentida e vivida no cotidiano, também nos procedimentos aos quais é submetido - não é validada pela equipe que o atende. Fica a imagem de uma equipe não-digna de confiança, que foi responsável pela sua cegueira.

"Eu chegava em casa era colírio de duas em duas horas, e eu não via melhora nenhuma. Fazia de tudo jeito, de tudo, aí eu ficava ansioso, tinha vez que dava vontade de pegar o olho e arrancar assim, da dor que eu sentia. Dar cabeçada na parede. [...] Porque esse último que o cara fez num foi laser, ele fez foi só ar alguma coisa aqui no meu olho, como que soldar. Queimando assim, eu sentindo e não parava de doer, e ele deu anestesia. E ele falou assim: Não, não, não tá doendo, isso é a sensação que você tá sentindo.... Que sensação a bunda dele, que sensação nada, tá é queimando. Parece que tava encostando um ferro quente assim dentro do olho... [...] Eu ali sofrendo de dor na mão dela e ela com aquela ignorância dela. Eu ali sentindo dor, esperando, e elas duas conversando sobre o passeio do dia anterior, e eu morrendo ali de dor. Eu morrendo de dor e elas com brincadeira e dando risada..." [Sr.Jair]. 
Ricardo também relata o sofrimento vivenciado ao sentir muita dor e ter sido interpretada como "fantasia":

"... Tive até um desconforto com um aluno, ele queria entrar um pouco mais na intimidade, brincar, que a minha dor que eu tava tendo ali, era meio que criação, fantasia. E não era né? Eu tava tendo muita dor; na última vez da operação, ele vinha brincando, e aí eu não gostei. Não gostei e falei: Poxa, ué, ele é médico ou não é, né? Aí vem a assistente social, coloquei a situação, aí veio o professor conversar [...] e ficou essa situação assim. Talvez ele quisesse fazer a visita, e ao ver o paciente lá com dor e tudo, brincar pra tentar fazer com que eu esquecesse, mas acabou que eu não aceitei muito isso não, porque quem tava sentindo a dor era eu, e quem queria ter mais, um pouco mais de medicamento para amenizar a dor era eu. Então tive esse desconforto..." [Ricardo].

Além da dor física, há um intenso sofrimento que envolve a situação, a limitação, o isolamento, as rupturas, as dificuldades e as necessidades, que devem ser incluídas e consideradas na vivência da dor. É possível tomar emprestado o conceito de dor total, cunhado no campo da assistência ao paciente oncológico, e que inclui aspectos emocionais, sociais, espirituais - e também não é acolhido neste sentido. Segundo Schisler ${ }^{66}$, o profissional de saúde deve sempre acreditar na experiência do paciente que afirma ter dor: "diz-se que a dor é o que o paciente diz que é, onde é e quando é" (p.49), bem como tratá-la, proporcionando impecável controle de sintomas.

Fátima também relata ter sentido muita dor pela doença ocular, e agradece o fato da intervenção livrá-la de tal sofrimento, ainda que não tenha sido possível retomar qualquer capacidade visual:

"Eu falei: 'Olha, a única coisa que me entristeceu, doutor, foi o senhor ter dito que eu tinha uma grande chance de 
enxergar, seu eu tivesse vindo pequena... Mas só em tirar as dores, estou me sentindo como se eu enxergasse...'. Porque eu não tinha prazer em comer, eu não dormia... Era tanta lágrima que saía, que eu não seu de onde vinha tanta lágrima que saía... Foi uma coisa assim horrível, que eu não desejo pra ninguém!" [Fátima].

Mas, mesmo com queixas e dificuldades, os sujeitos seguem na busca por atendimento e cuidados. Para Ayres $^{41}$, a reiteração da procura significa interesse legítimo no espaço da assistência, mas há uma "esterilidade mecanicamente vivida e repetida", sem que usuário e profissional encontrem um sentido para os recursos existentes no dia-a-dia um do outro.

Para alguns entrevistados, a busca por espaços de atendimento em saúde é ampliada para o sistema privado. Aliada às experiências negativas, parece haver uma desconfiança do sistema público, e, então, buscam confirmar diagnósticos e tratamentos em médicos dos convênios ou particulares, mesmo que isso signifique ser atendido pelo mesmo profissional nas duas instâncias. Há uma representação de segurança, agilidade e eficácia nos tratamentos - até mesmo status - ao conseguir pagar um convênio, ainda que majoritariamente (especialmente para os aspectos relacionados á deficiência) o acompanhamento seja feito em serviços públicos.

"Eu pago convênio, eu tenho medo do SUS! Não é medo do SUS, mas eu acho que esperar muito não dá..." [Cristina].

"Eu faço [tratamento] com o neuro; ele é do $\mathrm{HC}$ e da Intermédica. De segunda-feira eu tenho ele. E passo ainda com a gastro, porque agora o intestino começou a ficar ruim. [...] Teve uma vez que coincidiu: o mesmo médico que eu estava passando, eu fui passar em outro lugar era ele. E agora de novo: passo lá no $\mathrm{HC}$, quando chego na Santa Cecília é o mesmo médico, o Dr.Thiago. O Dr.Thiago é tão bom." [Ângela]. 
"Eu pus aquilo na cabeça, porque eu enxergava, cacete. Um pouquinho, mas eu enxergava. E minha irmã me levou nesse médico particular, pagou quatrocentos e poucos reais. Só que o médico é da mesma equipe [do HC]." [Sr.Jair].

Ricardo tem o plano da empresa e paga um a mais, por sua conta. Porém, mantém-se em contato com a UNIFESP, para acompanhamento em relação à Síndrome Pós-Pólio e busca no SUS a dispensação de equipamentos de auxílio, e a assistência nas emergências.

"Hoje eu tenho plano de saúde, da empresa. Pago um que cabe dentro das minhas possibilidades, por fora. 0 pessoa: Mas ô você... Você tem da empresa, mas você paga o seu... É, o meu é o meu, eu tinha antes de começar a trabalhar... [...] Então tenho ele hoje, tenho esses dois. E a gente vai nos PS da vida aí; mas só vou nos PS da vida quando trava alguma coisa, porque a coluna trava, dá um problema de sinusite, porque eu tenho as ites. Aí bato lá, e graças a Deus, que eu posso bancar isso hoje. Posso bancar um tratamento dermatológico, de uma doutora na Lapa que me trata com remédio manipulado, que ela pode pôr menos dosagem, mais dosagem. E aí eu posso pagar uma receita, que muita gente não pode. Duzentos reais, uma receita, não é todo brasileiro que pode bancar. [...] E hoje, graças a Deus, posso bancar isso. E isso me assusta, porque e se eu não pudesse? Já procurei os postinhos..." [Ricardo].

Outro aspecto importante é que, muitas vezes, a assistência a pessoas com deficiência é associada somente aos serviços de reabilitação. Há demandas não relacionadas especificamente à deficiência, que devem ser contempladas nos serviços que atendem à população em geral; questões relacionadas à deficiência poderão estar presentes nestes atendimentos, e ser acolhidas e encaminhadas para os serviços de referência. Porém, no modelo hegemônico, predomina a 
idéia de que só devem prestar assistência a esta população os serviços especializados. Nas palavras de Ricardo:

"O deficiente ficou meio rotulado que vai procurar só fisio, e não é. De uma forma geral, a gente adoece e aí vai ter que procurar vários profissionais." [Ricardo].

A própria reabilitação também é permeada por sentidos e significados construídos pelo sujeito em sua história. Sr. Jair, por exemplo, foi encaminhado para serviços de reabilitação, mas a distância, a necessidade de um acompanhante, as barreiras arquitetônicas, a fila de espera e a "falta de coragem" (em suas palavras) de transpor certas barreiras fazem com que ele não valide isso como necessidade. Sr. Jair também desconhece recursos disponíveis às pessoas com deficiência (como por exemplo, o ATENDE, transporte especializado disponibilizado pela Prefeitura do Município de São Paulo).

"Já me convidaram pra fazer, uma pessoa lá das Clínicas, pra fazer umas aulas. Aí marcou num lugar longe, para aprender a conviver sem enxergar, se movimentar, andar. Mas aí, pra mim ir lá e fazer essas aulas lá na Pompéia. Procurar... Aí eu liguei e marcou pra daqui dois meses, pra ver se tinha vaga, pra dar início. E eu vou ter que ocupar ela [esposa], e ela tem o neto pra olhar, tem a casa. Quer saber de uma coisa, vou ficar no meu lugar mesmo e se conformar. Era difícil a vaga... Então... Aqui no próprio posto também já falaram para participar de umas atividades. Mas tenho que ficar ocupando os outros, então... [...] Acho que eu não preciso disso, tô conformado. Se eu precisasse ainda trabalhar, ou se eu fosse depender pra fazer, de alguma outra coisa pra sobreviver, aí eu podia até correr atrás... [...] Não vai ser a salvação, dá pra mim viver conformado dentro de casa..." [Sr.Jair]. 
A partir destas falas, sobressai a necessidade de um trabalho de ajuda no enfrentamento dos confusos sentimentos e conflitos advindos da incapacidade, bem como para que este sujeito perceba suas potencialidades e capacidades.

Ângela encontra-se no outro pólo desta discussão. É ela quem pergunta à médica sobre a reabilitação e é ela quem pede o encaminhamento. As intervenções propostas pela equipe do centro de reabilitação ajudam-na a conseguir a almejada independência e o tão importante sentido no viver.

"Não é fácil [ir ao centro de reabilitação], mas também não é um absurdo. Não é nenhum absurdo, dá pra vir de perua. Quando dá pra vir de carro, minha irmã traz, quando não, a gente vem de perua. Não, não é fácil! [...] Eu sabia que não ia ter melhora de cem por cento, disso eu já estou bem ciente. E aqui o que eu aprendi foi muito bom. Aprendi com a nutricionista, a psicóloga me ajudou muito, a fisioterapia - eu sei que eu tenho que fazer em casa, eu aprendi aqui. E aquela melhora assim, eu sabia que não ia ter mesmo. Mas, eu acho que eu tive melhora mais do que eu esperava..." [Ângela].

Ricardo valoriza os tratamentos em reabilitação pelos quais passou, mas rompe com eles para "viver", em suas palavras. Isto é, entende (e opta) que não é possível passar a vida em tratamentos, em reabilitação; tem outros planos, outros projetos, como estudar e trabalhar. O papel da reabilitação (e da assistência à saúde somente neste plano) englobou toda sua vida como pessoa com deficiência, e foi necessário um movimento seu para romper com isso; segundo seu relato, os profissionais que o atenderam, não pareciam conceber outras possibilidades de existência a ele, sem ser no caminho árduo dos tratamentos, procedimentos e reabilitação.

Na história de Ângela, na época em que foi realizada a entrevista, ela teria alta do centro de reabilitação, algo almejado por ela, pois entende que já 
aprendeu tudo que foi possível. Ela estava em busca de outros espaços de assistência, especialmente um indicado pela própria instituição.

É importante tecer dois comentários acerca deste movimento de Ângela. A ida ao centro de reabilitação tem papel fundamental em seu cotidiano, é a tarefa do seu dia-a-dia, é a atividade significativa que tem, dizendo inclusive que vai para o seu "trabalho" (em suas próprias palavras). Nota-se que não há outros espaços para ela exercer esta função produtiva, não necessariamente ligada ao trabalho remunerado (e ela própria faz esta colocação em seu relato) e, então, o serviço de saúde ocupa esta função. Ao ter alta, ela busca outros equipamentos do sistema de saúde, para ocuparem o espaço do trabalho e da convivência, caracterizando um movimento comum de peregrinação entre os serviços. O acesso e a disponibilidade aos espaços e oportunidades de estudo, trabalho, lazer, convivência são ainda precários, contribuindo para este caminho. Como já mencionado anteriormente, para Fátima, o mesmo movimento acontece, e ela utiliza a instituição de reabilitação que freqüenta como uma mistura de escola, trabalho e lazer.

\begin{abstract}
"Eu penso assim... Quando eu ganhar alta daqui, ou eu vou lá pra ABEM ou vou pra Lapa, e eu vou fazer crochê. Falei pra minha irmã: 'Agora, eu não vou parar mais em casa...'. E procurar sempre se ocupar... Quando eu venho pra cá, eu brinco assim: 'Agora estou indo pro meu serviço, agora estou indo trabalhar, tô atrasada...'. Se a gente ficar em casa, ficar pensando: 'Ah, minha perna hoje está tremendo... Ah, estou com tanta dor nas costa...'. Tem coisas que é rotina, e parece que é pior..." [Ângela].
\end{abstract}

Assim como discutido no aspecto da adesão aos programas de reabilitação, o uso dos aparelhos e equipamentos de tecnologia assistiva é permeado de sentidos e significados para o sujeito. Para Cristina, por exemplo, usar o aparelho auditivo é difícil, envolve vergonha e medo de assumir a deficiência; 
em sua história, todo o seu movimento é de negação da condição e da deficiência, e o aparelho é parte disso.

\begin{abstract}
"O aparelho é pequenininho, tem gente que vê... E às vezes: Ah, Cristina, pensei que você tinha uma espinha... Porque pra você puxar o aparelho, ele tem essa coisinha aqui. Ele é pequeno, pequenininho, tem até menores. [...] Às vezes não me incomodo [que perguntem sobre o aparelho], porque de repente alguém precisa saber, a gente conversa. Mas, às vezes, eu fico constrangida com a deficiência. Acho que deve ser bom você não precisar de aparelho..." [Cristina].
\end{abstract}

No aspecto da assistência, além da prescrição e dispensação destes dispositivos de auxílio, a história do sujeito deve ser ouvida, considerada e valorizada. Novamente, toma-se como fundamental o cuidado e escuta realmente interessada no sofrimento e na ajuda ao outro.

Em todos os aspectos trazidos nesta discussão, há que se valorizar o movimento do próprio sujeito em seu processo de enfrentamento da deficiência, da relação com o contexto familiar e social, da busca por alternativas e condições que possibilitem melhor qualidade de vida.

Ângela e Fátima ressaltam suas participações nas conquistas que tiveram, bem como a importância da ajuda no despertar desta força e coragem:

\footnotetext{
"Mas, eu acho que tudo começa pela gente também. Se a gente não lutar, não começar a conversar, falar o que quer e o que não quer, vai sempre ficar encostado num canto. [...] Porque eles olham a gente sempre com olhar de coitados. E não é, às vezes não é isso... Quando eu entro no ônibus, na perua, eu sinto... Na rua, se eu ando com a minha irmã... Agora, se você anda sempre, você vai perdendo isso. Eu já perdi bastante. Agora, se uma pessoa olha pra bengala, eu também olho. Não ligo mais! Às vezes a pessoa não tem ninguém na família... [...] Também teve uma mudança minha. Mas por quê? Porque eu comecei a sair, me interessei mais pra saber do meu
} 
problema... Porque se você fica em casa, não se interessa nem pra saber... E, foi aqui, foram as cobranças que eu tive da psicóloga, da assistência social, da enfermagem, da nutricionista... Foi muito bom!" [Ângela].

"Tem os altos e os baixos, mas dá pra gente passar... Eu aprendi uns cursos aqui [instituição]. Depois que eu estou aqui, aprendi a fazer salgados, aprendi a fazer doces, e inclusive eu faço salgados pra fora, pra vender. Eu faço sequilhos de porvilho pra vender. $\mathrm{E}$ com isso eu vou sustentando a minha casa também, e a mim... Vai dando uma ajuda... Graças a Deus que tem muitos amigos que também ajudam, e eu vou levando a vida. Não é fácil, mas vou levando a vida... Não é fácil, mas também não é difícil se você quiser..." [Fátima].

\section{5 - Ações e estratégias}

Dos dados da pesquisa, o último tema produzido pelas narrativas dos entrevistados foi a proposição de ações e estratégias para atender às necessidades da pessoa com deficiência.

A veiculação de informação foi um dos tópicos levantados, seja no tocante à informação em saúde (para prevenção de deficiências, diagnósticos precoces, prevenção de incapacidades), seja relacionado a aspectos gerais de educação, trabalho, direitos e cidadania.

É importante ressalta que a adesão da população às ações em saúde não depende somente da transmissão de conteúdos sobre doenças e maneiras de preveni-las. Ayres et al. ${ }^{67}$ consideram que a chance de exposição das pessoas ao adoecimento deve ser considerada como resultante de um conjunto de aspectos não apenas individuais, mas também coletivos, contextuais, que acarretam maior suscetibilidade à infecção e ao adoecimento e, de modo inseparável, maior ou menor disponibilidade de recursos de todas as ordens para se proteger de 
ambos. Como trabalhado anteriormente, deve-se considerar ainda os sentidos que as intervenções ecoam na vida de cada sujeito, a partir de sua história.

Há também ações e estratégias próprias, que os sujeitos vão encontrando para facilitar seu cotidiano: é o óculos escuro para o Sr.Jair, o planejamento para os passeios e trajetos na cidade de Ricardo, a atenção à fala e aos lábios ao conversar da Cristina, os recursos caseiros para fazer os exercícios que Ângela utiliza são alguns dos exemplos. Faz-se necessário que os profissionais de saúde interessem-se e validem estratégias próprias dos sujeitos, havendo uma permeabilidade do técnico ao não-técnico ${ }^{41}$. Cada uma destas pessoas tem sua "sabedoria prática", nas palavras deste autor.

A orientação à família se faz fundamental, como colocado pela entrevistada Fátima, a fim de evitar situações de superproteção e simbiose paciente/cuidador, bem como promover maior autonomia e independência da pessoa com deficiência. Orientação, informação e apoio à família são papéis importantes da equipe de saúde que acompanha o sujeito com deficiência, e Cristina chama a atenção para situações de sobrecarga do cuidador.

Silva ${ }^{57}$ reforça que o papel do cuidado é culturalmente feminino, e que as equipes de assistência em saúde reforçam este aspecto, pois orientam prioritariamente as mulheres da família sobre os cuidados. Refere ainda que, na impossibilidade das mulheres exercerem o cuidado, as pessoas com deficiência acabam sendo encaminhadas para abrigos ou instituições de caridade. Ela afirma que é preciso desconstruir esta naturalização do cuidado como tarefa essencialmente feminina, e implementar políticas que abranjam aqueles que cuidam de pessoas com deficiência.

Para Ângela, no relacionar-se com as pessoas (com deficiência ou não), o respeito é fundamental, e esta lição é que procura passar na educação de seu filho. De uma maneira ou de outra, todos os relatos nesta pesquisa contam desta busca e desta necessidade: o respeito acima de tudo. 
"E eu falo pra ele: Respeite os outros... Você não é obrigado a gostar de ninguém, a respeitar você é obrigado... É verdade, a gente não é obrigado a gostar de ninguém, mas respeito a gente tem que ter. Só que parece que está fora de moda. Que ridículo! Eu falo: Não, não interessa! Você tem que ter respeito com a sua professora, o seu colega..." [Ângela].

É importante destacar que o envolvimento em atividades significativas e produtivas são fundamentais à pessoa com deficiência, em sua auto-estima e dignidade. De acordo com Ferrari ${ }^{68}$, é através da ação que o indivíduo explora, domina e transforma a si e o mundo que o cerca; cria, descobre, aprende, se relaciona, se realiza, ou seja, constrói sua própria história. A vida é um grande conjunto de ações e fazeres - dependentes da história dos sujeitos, do contexto sociocultural - e deficiência pode implicar em mudanças nos padrões estabelecidos cultural e socialmente, ou até mesmo interrupções e rupturas. Assim, fica clara a necessidade do sujeito retomar e/ou descobrir atividades e ocupações que Ihe sejam significativas.

Cristina e Ângela, à sua maneira, abordam esta questão no relato que fazem:

"Porque eu sempre pensei, uma vez eu ouvi um cara falando assim que, as pessoas lembram de você e falam de você por aquilo que você faz, não se você é bonitinha, é alta, magra... Mas é lembrado: Sabe aquela Cristina? Aquela que trabalha, que fez isso, faz aquilo... Aquilo que a gente constrói, não pela aparência... [...] Elas [as pessoas com deficiência] precisam viver, elas precisam de trabalho, precisam ter uma vida produtiva. A gente precisa produzir alguma coisa. Eu acho que teria que ter condições. [...] Se você não tiver a vida, não se sentir produtiva, aí você vai pro poço... Acho que a sociedade, o governo, precisa dar apoio pra isso, suporte pras pessoas..." [Cristina]. 
"Eu acho que [as pessoas com deficiência precisam] se ocupar, com qualquer coisa. Mesmo que as pessoas olhem, mesmo que seja um trabalho comunitário, mesmo que seja um trabalho pra ganhar dinheiro, mas sempre se ocupar. [...] E ocupar, ocupar a pessoa que tem esse problema, ocupar a mente dela... Ela pode ser um voluntário, dependendo do que ela faz, do que ela é, ela não precisa... Pode ser um voluntário, pode ajudar alguém... Melhor do que ficar no canto, vendo televisão ou aborrecida..." [Ângela].

Mesmo sem encontrar sentido e forças para concretizar este desejo, o Sr. Jair também aponta a importância de estar envolvido com uma atividade significativa:

"E é uma coisa boa, se eu tivesse uma pequena porcentagem [da visão], eu ia arrumar uma ocupaçãozinha aí. Sinto falta, pelo menos de sair de casa. Quer dizer, se eu tivesse condições eu acharia bom, era uma distração..." [Sr.Jair].

Neste campo, deve-se pontuar que a sociedade capitalista valoriza o ser produtivo e, concomitantemente, associa-se a idéia de não-valor para aquele que não é produtivo economicamente ${ }^{46}$ como velhos e pessoas com deficiência. Para o Sr. Jair, assumir sua aposentaria por invalidez - por exemplo - também vem recheada de um ideal de "não-valor", do estigma do não produtivo. Ayres ${ }^{65}$ propõe ampliar o conceito de produtivo, trazendo a noção de sucesso prático, que pode ou não passar pela produção de bens; assim, é preciso subsumir a idéia de êxito técnico das ações de cuidado ou de produtividade, no plano dos resultados, na de sucesso existencial, podendo abrir o conceito para os diferentes modos de andar a vida, o que é particularmente importante no caso das pessoas com deficiência.

Estar aberto à alteridade do encontro usuário-profissional também é fundamental na assistência às pessoas com deficiência, entendendo que já 
estamos imersos em um diálogo ${ }^{65}$, em que predomina o não-valor e o estigma da pessoa com deficiência.

É preciso considerar ainda o estereótipo do profissional de saúde que o usuário deverá desconstruir; para o Sr. Jair, por exemplo, os bons médicos são aqueles mais velhos e experientes. O peso da palavra do médico também é muito grande, e isto pode influenciar negativamente a construção de uma relação menos hierárquica e mais dialógica.

"Era só o que eu ouvia, o povo lá reclamando lá dentro. Eu sentando lá esperando, só ouvia as gente reclamando de estagiário. Mas eu já enxergar nada. O povo falava assim: "Isso não é médico, é um moleque...". Médico tinha que ser pessoa de idade, tinha que demonstrar habilidade, tinha mais responsabilidade. Agora esses estagiários, a gente vai de cobaia. Quando essa médica aí me atendia, eu não via professor nenhum lá perto não" [Sr.Jair].

Nas práticas em saúde, é preciso criar um movimento de desconstrução destas representações e estereótipos, de abertura à diferença, para um verdadeiro encontro intersubjetivo, e também para favorecer espaços mais inclusivos, e intervenções que promovam a autonomia e a circulação social. E, com isso, a convivência com o outro se põe em questão. Faz-se necessário entrar em contato com o outro, a partir das capacidades do sujeito, possibilitando maior interação do sujeito com sua comunidade e seu meio social, desmistificando a deficiência (como categoria negativa) e ampliando possibilidades de circulação e participação sociais. Partindo-se do referencial do paradigma social, proposto por autores como Almeida et al. ${ }^{2}$, Oliver et al. ${ }^{34} \mathrm{e}$ Oliver et al. ${ }^{35}$, em que a garantia de direitos, a construção de redes de apoio social, a criação de oportunidades de ampliação da sociabilidade devem ser eixos para a prática em saúde da pessoa com deficiência, as práticas em saúde podem 
atuar como promotoras e possibilitadoras deste novo tipo de relação, pautadas nas potencialidades dos sujeitos envolvidos.

\section{6 - Necessidades de saúde das pessoas com deficiência}

A partir do objetivo geral colocado para a pesquisa, de identificar quais são as demandas e necessidades de saúde das pessoas com deficiência, a partir da ótica destes sujeitos, torna-se importante tecer ainda algumas considerações acerca do objeto específico deste estudo.

Diante do modelo de análise adotado, em três níveis: palavras-chave, temas emergentes e tendências gerais ${ }^{51}$, apresentam-se aqui as tendências gerais acerca das necessidades de saúde: onze núcleos temáticos centrais, sintetizando as discussões e retomando o objetivo deste estudo. Estes núcleos estão apresentados em ordem alfabética, sem hierarquização de prioridades.

\section{- Acesso}

É preciso possibilitar o acesso das pessoas com deficiência aos serviços de saúde e de reabilitação, bem como acesso a oportunidades de emprego, estudo, lazer, convivência, circulação social. Há aspectos que estão para além do acompanhamento individual em saúde, mas em processos sociais extremamente complexos: falta de acessibilidade urbana, pouca permeabilidade do social à diferença, preconceito discriminação. Fica premente a necessidade de propostas e ações intersetoriais diante das questões desta população.

\section{- Apoio psicossocial}


É necessário haver espaço nas ações em saúde para esta população para que possam ser ajudadas a elaborar as perdas e mudanças decorrentes da deficiência e sua irreversibilidade. São momentos difíceis, que mobilizam uma gama de sentimentos conflitantes (raiva, vergonha, inconformismo, tristeza, angústia, culpa, etc.). Anterior a uma abordagem específica, escuta, apoio e acolhimento devem ser proporcionados por todos os profissionais de saúde. Ativação de redes de suporte e ações de orientação e apoio junto à família e comunidade são outros focos de ação fundamentais.

Faz-se um destaque para a questão da ruptura vivenciada pela pessoa com deficiência adquirida, com complexidades específicas que terão que ser acolhidas pelos profissionais e serviços de saúde.

\section{- Aspectos gerais de saúde (para além da deficiência)}

Para além dos aspectos específicos da deficiência, os sujeitos têm outras questões de saúde (como, por exemplo, cuidados odontológicos e ginecológicos, emergências), e estas devem ser identificadas, valorizadas e acolhidas nos serviços de saúde utilizados por todos os cidadãos, não vinculando estes aspectos a serviços específicos de reabilitação ou de atendimento a pessoa com deficiência.

\section{- Autonomia e independência}

Devido às incapacidades decorrentes da deficiência, é necessário trazer autonomia (escolha) e a maior independência possível (fazer sozinho) para a pessoa com deficiência, trabalhando suas capacidades e potencialidades, aspectos muito valorizados pelos sujeitos entrevistados na pesquisa. 


\section{- Dispensação de equipamentos e dispositivos de tecnologia assistiva}

Os equipamentos de ajuda são fundamentais para alguns tipos de deficiência, possibilitando autonomia, independência e dignidade: cadeiras de rodas, bengalas, muletas, órteses e próteses são alguns exemplos. Além destes, pode haver necessidade de equipamentos menos diretamente ligados à funcionalidade e à reabilitação, como sondas e coletores, por exemplo. Esta dispensação é prevista em leis específicas, porém são comuns os relatos de dificuldade no acesso a estes dispositivos.

\section{- Informação / orientação}

A informação é importante para a prevenção e detecção precoce das deficiências, pois permite que o usuário tenha mais conhecimento sobre seu próprio corpo, ao que estar atento, quando procurar o médico. Também é preciso haver orientação sobre o quadro da deficiência, as incapacidades decorrentes, o prognóstico, o tratamento, os procedimentos que serão realizados e a reabilitação. É importante ressaltar que estas informações/orientações devem ser trabalhadas junto com o usuário, em seu contexto social e cultural.

Além disso, como as deficiências são ainda irreversíveis, o prognóstico é algo importante a ser trabalhado, de maneira lenta e progressivamente suportável, ajudando o sujeito a elaborar as mudanças em seu modo de andar a vida. Por fim, a informação e a orientação devem estar relacionadas a aspectos gerais de direitos e cidadania.

\section{- Prevenção / diagnóstico precoces}


Muitas deficiências são passíveis de prevenção (como aquelas decorrentes de doenças crônicas, de causas externas, etc.) e poderiam ser evitadas. Além disso, precisam ser detectadas precocemente, permitindo intervenção precoce e minimizando as incapacidades decorrentes do quadro. Nas histórias desta pesquisa, este aspecto apareceu pelo lado inverso: muitos tiveram seu diagnóstico tardio e, como conseqüência, maiores incapacidades.

\section{- Reconhecimento e garantia de direitos}

Os direitos das pessoas com deficiência estão garantidos pela constituição; porém, ainda é vigente o imaginário da caridade e do favor para com as minorias. É necessário um trabalho de "conscientização" e validação destes direitos, incluindo os direitos de assistência à saúde. As ações não se restringem à saúde, mas devem ser intersetoriais; a comunicação, a interação e a ação conjunta entre os setores fazem-se necessárias.

\section{- (Re)Encontro com atividades significativas}

A partir das rupturas do cotidiano e do estigma da deficiência, o sujeito fica em um lugar de não-valor para si e para os outros. Emerge a necessidade de (re)encontrar atividades que lhe façam e que Ihe tragam sentido, possibilitando a retomada de um lugar de valor, ação e interação com o contexto em que vive. É importante ressaltar que estas atividades não estão necessariamente ligadas ao contexto de produção, mas do sentido construído junto a cada sujeito, ligado à história individual, familiar e cultural de cada um. 
- Validação e ajuda na construção de estratégias próprias de enfrentamento

\begin{abstract}
A partir das dificuldades e limitações impostas pela deficiência, o sujeito vai encontrando em seu cotidiano estratégias próprias de elaboração e enfrentamento concreto. O percurso nos serviços de saúde também está relacionado a estes mecanismos particulares. Faz-se necessário validar-se cada sujeito como único e singular, bem como compreender e incentivar as ricas possibilidades, capacidades e saberes de cada um.
\end{abstract}

\title{
- Vínculo com profissional de saúde
}

O estabelecimento relação de confiança com um profissional de saúde e/ou com serviço de saúde é uma necessidade: ser cuidado, ouvido, orientado, valorizado em uma relação mútua e dialógica. Outra questão aqui fundamental, importante de ser ressaltada, é o respeito a dor, que é própria de cada sujeito, em todas as suas dimensões.

Enfim, tomando-se como referência para a prática em saúde o cuidado ${ }^{41}$, em que o principal interesse é o sentido existencial da experiência do adoecimento, buscando ouvir genuinamente o outro e buscando com ele (re)construir seus projetos de felicidade, fica inerente para a assistência à pessoa com deficiência a (re)construção dos sentidos da vida, práticos e existenciais, numa vida que valha a pena ser vivida. Projetos de vida e desejo são idéias centrais para a resposta às necessidades de saúde das pessoas. E, é preciso haver espaço nos serviços de saúde para acolher estas demandas, não somente aquelas de ordem física. Segundo Silva ${ }^{57}$, é preciso compreender o 
encontro médico como um processo no qual profissionais e pessoas com deficiência refletem sobre o tipo de vida vivida e como melhorar o modo de viver.

É premente que haja uma "fusão de horizontes"69 entre médico e paciente, para que possam compartilhar as informações e valores de maneira mais dialógica, contribuindo para a construção de uma relação de confiança, e que também possa acolher a condição irreversível da deficiência. Faz-se necessário ajudar o sujeito a reconstruir as relações que ele estabelece entre sua deficiência, as mudanças dela advindas, seus sentimentos e sua vida. É preciso considerar seu sofrimento, entendendo que esta é uma experiência individual e singular, ainda que possa ser compartilhada com outras pessoas.

Além disso, é preciso considerar que as necessidades estão para além da saúde: direitos, cidadania, educação, transporte, lazer. Tornam-se imprescindíveis ações intersetoriais, considerando-se as especificidades que a vivência da deficiência impões, as necessidades gerais de qualquer cidadão em seu contexto sócio-cultural, bem como o sentido de cada uma das proposições dentro da história de vida de cada sujeito.

A partir das palavras do Sr. Jair, precisamos possibilitar que as pessoas com deficiência voltem a sonhar, mesmo sem enxergar (ou com outras limitações), a sentirem-se libertas novamente, através de intervenções baseadas na integralidade e no cuidado. Esse é o principal objetivo das ações junto a esta população, e está aí o cerne de suas necessidades. 


\section{Considerações Finais}

$\mathrm{Na}$ análise das entrevistas, foram construídas cinco tendências gerais: a vivência da deficiência; independência, autonomia e apoio; acesso e direitos; percursos e sentidos das intervenções em saúde; ações e estratégias.

No primeiro item, a vivência da deficiência, os principais temas discutidos foram as especificidades do viver com deficiência, os contatos com o mundo, as relações com as pessoas (em que a tônica da superproteção ou da discriminação e do preconceito estiveram fortemente presentes), o ritmo e a organização do cotidiano. Ficam explícitas as diferenças entre a deficiência congênita e a deficiência adquirida (recorte já colocado também pela metodologia), como algo que traz diferenças importantes na vivência: a ruptura versus o apreender o mundo por diferentes modalidades sensório-motoras. De qualquer maneira, também fica explícito no relato o desejo (e uma possível busca) pela "normalidade", modelo adotado como referência, como um mecanismo de enfrentamento da condição de irreversibilidade imposta pela deficiência.

Os sentimentos mobilizados são diversos, a partir da história singular, do contexto em que se insere, e do tipo de deficiência; porém, palavras como trauma, vergonha, medo, decepção permeiam o discurso. Em relação às explicações sobre a deficiência, a religião (e a idéia de castigo, culpa, transcendência ou aprendizado), a noção de acidente e/ou fatalidade, e a genética/hereditariedade são concomitantes em vários relatos.

Ressalta-se que, na literatura, apresentam-se críticas ao quão pouco se aborda a vida da pessoa com deficiência. Ao ouvir os sujeitos e suas histórias, este tema teve grande e intenso destaque, sendo na pesquisa - de fato fundamental para a compreensão das necessidades desta população. 
No segundo item - independência, apoio e autonomia - fica clara a valorização da independência e da autonomia, como forma de dignidade enquanto sujeito, já colocada pelo autor Cecilio $^{21}$, como um dos conjuntos de necessidades de saúde, a "autonomia nos modos de andar a vida". Porém, alinhada à idéia de autonomia/independência, está posta a noção de apoio e ajuda, como fundamental para as pessoas com deficiência, a partir de uma atitude de respeito, compreensão e acolhimento às diferenças.

Em relação ao terceiro item - acesso e direitos - coloca-se sua importância para ampliar as possibilidades da pessoa com deficiência ser/estar no mundo como sujeito de direitos, como cidadã. Acesso e direitos envolvem questões em seu sentido mais ampliado: acessibilidade urbana e arquitetônica, oportunidades, lazer, cultura, trabalho, educação, saúde, dispensação de equipamentos de auxílio, transporte, informação, etc. Ainda que garantidos por lei, o acesso a muitos direitos conquistados pelas pessoas com deficiência permanece falho, com muitos relatos de dificuldades e movimentos em busca de conquista.

O quarto item relaciona-se exclusivamente ao campo da saúde: percursos e sentidos das intervenções em saúde. Explicita-se que os itinerários e percursos de cada sujeito em busca de sua assistência à saúde são vários, a partir da história, dos recursos, da rede de apoio e do contexto sociocultural de cada sujeito. Percursos que envolvem diretamente a questão da deficiência, mas também itinerários que buscam os cuidados relacionados à saúde em geral, como cidadãos.

Em um item final - ações e estratégias - pôde-se construir a partir do relato dos entrevistados a noção de quais caminhos de possibilidades são válidos para estes sujeitos. Veiculação de informações, estratégias cotidianas próprias, valorização da autonomia e da independência, respeito nas relações, 
envolvimento em atividades de sentido e de valor para cada pessoa e desconstrução de estereótipos foram os principais temas que emergiram.

Por fim, construiu-se então, em consonância com o objetivo geral da pesquisa, onze núcleos temáticos de necessidades de saúde da pessoa com deficiência, destacando-se que há núcleos relacionados à saúde especificamente, mas núcleos mais amplos, que envolvem o viver com deficiência em todas as suas variáveis:

- Acesso

- Apoio psicossocial

- Aspetos gerais de saúde (para além da deficiência)

- Autonomia e independência

- Dispensação de equipamentos e dispositivos de tecnologia assistiva

- Informação / orientação

- Prevenção / diagnóstico precoce

- Reconhecimento e garantia de direitos

- $\quad(R e)$ Encontro com atividades significativas

- Validação e ajuda na construção de estratégias próprias de enfrentamento

- Vínculo com profissional de saúde

Dentre todo o processo de realização da pesquisa, é importante ressaltar que a técnica da história de vida adotada concretizou a possibilidade de abrir o espaço para o pensar do sujeito sobre sua própria história e sobre suas necessidades. Gadamer ${ }^{69}$ pontua que a reflexão biográfica ou autobiográfica (concretizada neste trabalho a partir da metodologia escolhida) é um processo ininterrupto de construção de significados, fundido ao movimento da vida; vão construindo-se novos significados a partir do vivenciado, em um processo inesgotável para cada vivência. 
O vivenciado é sempre a vivência que alguém faz de si mesmo, e o que ajuda a construir seu significado é o fato de ele fazer parte da unidade desse si mesmo e conter uma referência inconfundível e insubstituível com o todo dessa vida una. Nesse sentido, não se esgota essencialmente no que se pode transmitir dele nem no que se pode ficar como seu significado. A reflexão autobiográfica ou biográfica, onde se determina seu conteúdo significativo, fica fundida no todo do movimento da vida e continua acompanhando-a ininterruptamente (pg.113).

Porém, a pesquisa apresentou um recorte em sua população, incluindo pessoas com deficiência física, visual e auditiva (congênita e adquirida), em um grau que possibilitasse a participação e a realização das entrevistas. Ainda que tomemos a deficiência com um tema transversal nas práticas em saúde, sugerese outros estudos que aprofundem o estudo de cada uma das deficiências, avaliando as possíveis especificidades de cada grupo, bem como estudos que considerem os diferentes graus de acometimento. Pereira ${ }^{9}$ menciona que as pessoas com deficiência apresentam um mosaico de necessidades, e as especificidades devem ser contempladas:

A falta de informação encobre uma dimensão da deficiência que é, ao mesmo tempo, física, psicológica e social: as pessoas com deficiência são muito diferentes entre si, embora o estigma da deficiência tenha induzido a população em geral a acreditar que as pessoas com deficiência são todas igualmente limitadas, igualmente incapazes. Esta diferença, que é tão evidente, mas, ao mesmo tempo, ignorada, faz da deficiência uma condição - e, por extensão, um conceito - absolutamente relativo (p.45).

Enfim, neste trabalho, pôde-se verificar que as necessidades são amplas, envolvem aspectos, ações e estratégias diferentes, em uma abordagem intersetorial. Na prática cotidiana, é imprescindível tomar a noção de "fusão de horizontes $^{\prime 69}$ como prioritária, uma vez que se pôde compreender que os 
sentidos construídos por cada sujeito sobre sua deficiência e suas necessidades é o que constrói seu percurso na assistência em saúde, e na busca por seus direitos de um modo geral.

Tomando três palavras utilizadas pelo Sr. Jair, podemos resumir as necessidades das pessoas com deficiência: compreensão, condução e cooperação. 


\section{Anexos}

\section{Anexo A}

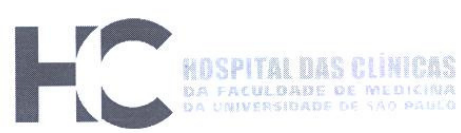

\section{APROVAÇÃO}

A Comissão de Ética para Análise de Projetos de Pesquisa CAPPesa da Diretoria Clínica do Hospital das Clínicas e da Faculdade de Medicina da Universidade de São Paulo, em sessão de 10/09/2008, APROVOU O Protocolo de Pesquisa $n^{\circ}$ 0494/08, intitulado: "ATENÇĀO À SAÚDE DA PESSOA COM DEFICIÊNCIA - NECESSIDADES SOB A PERSPECTIVA DOS SUJEITOS." apresentadO pelo Departamento de MEDICINA PREVENTIVA, inclusive $\bigcirc$ Termo de Consentimento Livre e Esclarecido.

Cabe ao pesquisador elaborar e apresentar à CAPPesq, os relatórios parciais e final sobre a pesquisa (Resolução do Conselho Nacional de Saúde n० 196, de 10/10/1996, inciso IX.2, letra "c").

Pesquisador (a) Responsável: José Ricardo de Carvalho Mesquita Ayres Pesquisador (a) Executante: Marilia Bense Othero

CAPPesq, 11 de Setembro de 2008

Prof. Dr. Eduardo Massad Presidente da Comissão de Ética para Análise de Projetos de Pesquisa

Thlape Ruen alvel ho

Hillegonda Maria Dutilh Novaes

Coordenadora do Programa de Pós-Craduaçào

do Depto de Medicina Preventiva

Comissăo de Ética para Análise de Projetos de Pesquisa do HCFMUSP e da FMUSP Diretoria Clínica do Hospital das Clinicas da Faculdade de Medicina da Universidade de Sắo Paulo Rua Ovidio Pires de Campos 255, $5^{\circ}$ andar - CEP 05403010 - Sắo Paulo - SP Fone: 01130696442 Fax: 01130696492 e-mail cappesq@hcnet.usp.br/ secretariacappesq2@hcnet.usp.br 


\section{Anexo B - Roteiro de entrevistas}

\section{PARTE I - Vida, sujeito e história}

A. História familiar: local de nascimento, descendência, história dos antepassados.

B. Infância: o brincar, a escolarização, a relação com a família e participação nos contextos familiares, as amizades e contato com outras crianças.

C. Adolescência: o encontro com a sexualidade, os interesses afetivos, as prospecções para o futuro.

D. Vida adulta: a constituição de família, a vida de trabalho.

E. Deficiência: aquisição, momento da "notícia" (diagnóstico), restrições e possibilidades, rupturas vividas (especialmente quanto a deficiências adquiridas), preconceitos, circulação pela cidade, autonomia e independência, crenças e valores.

F. Cotidiano atual: fazeres, gostos, vontades, atividades que realiza, dificuldades que encontra.

\section{PARTE II - Assistência em saúde}

A. Espaços de intervenção: Percurso no sistema de saúde, serviços que freqüentou, em que momentos da vida e porquê. Serviços de reabilitação e serviços não-específicos.

B. Experiências nestes serviços: relação com profissionais de saúde, relação com outros pacientes, impressões e vivências (positivas e negativas).

C. Resultados alcançados: satisfação com as intervenções, o que poderia ser diferente, melhorias alcançadas, sentido para o sujeito.

D. Demandas e necessidades de saúde: quais identifica em sua vida (momento atual e pregresso) e resoluções; sugestões para a assistência à saúde das pessoas com deficiência.

\section{Parte III - Outros comentários}

(Livre narração a partir do interesse do entrevistado). 


\section{Anexo C - Roteiro do diário de campo}

\section{Parte I - Descrições}
A. Ambiente de realização da visita (espaço físico).
B. Residência do entrevistado (quando possível) - disposição dos quartos e móveis, espaço da pessoa com deficiência na casa, condições de acessibilidade.
C. Comportamento do entrevistado, eventos particulares durante as falas, receptividade.
D. Acontecimentos específicos - interrupções e motivos, desdobramentos, etc.

\section{Parte II - Reflexões e impressões}

A. Impressões acerca da entrevista, do entrevistado, sentimentos experimentados durante o trabalho.

B. Hipóteses, inferências, especulações e palpites que emergirem durante a entrevista.

C. Dificuldades e dúvidas encontradas pelo entrevistador. 
Anexo D - Termo de consentimento livre e esclarecido

\section{FACULDADE DE MEDICINA DA UNIVERSIDADE DE SÃO PAULO-HCFMUSP}

TERMO DE CONSENTIMENTO LIVRE E ESCLARECIDO

DADOS DE IDENTIFICAÇÃO DO SUJEITO DA PESQUISA OU RESPONSÁVEL LEGAL

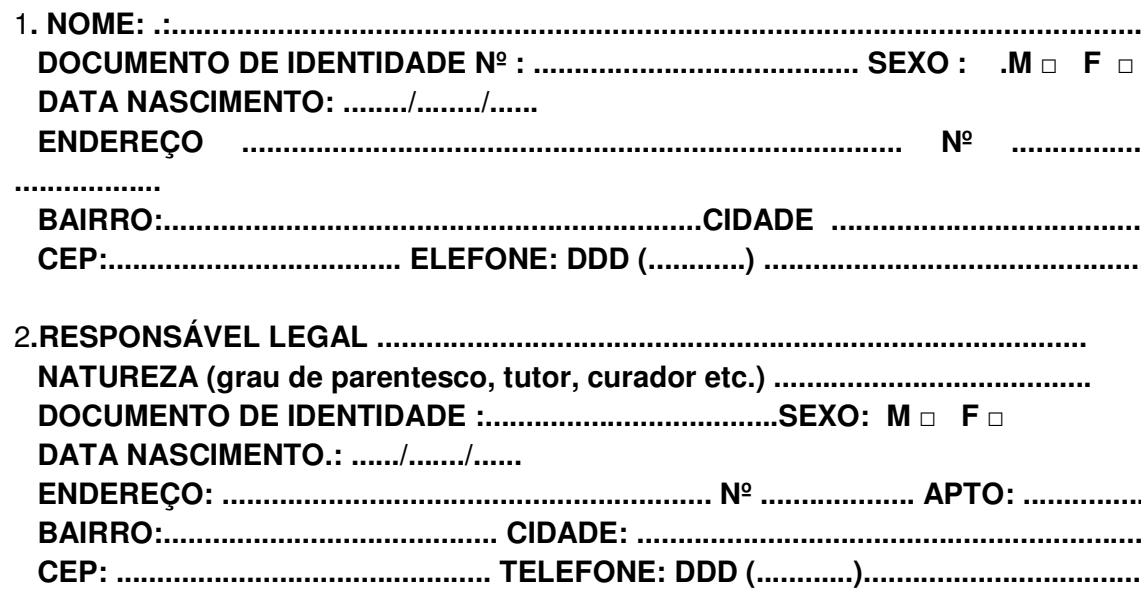

BAIRRO:

CIDADE

CEP: ELEFONE: DDD

...)

2.RESPONSÁVEL LEGAL

NATUREZA (grau de parentesco, tutor, curador etc.) DOCUMENTO DE IDENTIDADE : SEXO: $M \square F \square$ DATA NASCIMENTO.:

ENDEREÇO: BAIRRO: № APTO:

CEP: CIDADE: TELEFONE: DDD (

APTO:

DADOS SOBRE A PESQUISA

1. TÍTULO DO PROTOCOLO DE PESQUISA:

ATENÇÃO À SAÚDE DA PESSOA COM DEFICIÊNCIA - NECESSIDADES SOB A PERSPECTIVA DOS SUJEITOS

PESQUISADOR: Marilia Bense Othero

CARGO/FUNÇÃO: Terapeuta Ocupacional - Mestranda INSCRIÇÃO CONSELHO REGIONAL № CREFITO 3 / 8112 - TO ORIENTADOR: Prof. Dr. José Ricardo de Carvalho Mesquita Ayres UNIDADE DO HCFMUSP: Departamento de Medicina Preventiva 


\section{AVALIAÇÃO DO RISCO DA PESQUISA:}

RISCO MÍNIMO

RISCO BAIXO
RISCO MÉDIO

RISCO MAIOR

3.DURAÇÃO DA PESQUISA : agosto de 2008 a agosto de 2010.

1 - Essas informações estão sendo fornecidas para sua participação voluntária neste estudo, que tem como objetivo identificar as demandas e necessidades de saúde das pessoas com deficiência a partir da ótica destes sujeitos, uma vez que as práticas em saúde encontram limitações para responder às complexas necessidades das pessoas.

2 - Convidamos-Ihe a participar do estudo, por estar incluído em uma das categorias abaixo:

- Pessoa com deficiência física, do sexo masculino ou feminino, entre 40 e 65 anos, com deficiência congênita ou adquirida, tendo freqüentado no passado ou atualmente algum serviço de saúde de atenção à pessoa com deficiência no SUS;

- Pessoa com deficiência visual, do sexo masculino ou feminino, entre 40 e 65 anos, com deficiência congênita ou adquirida, tendo freqüentado no passado ou atualmente algum serviço de saúde de atenção à pessoa com deficiência no SUS;

- Pessoa com deficiência auditiva, do sexo masculino ou feminino, entre 40 e 65 anos, com deficiência congênita ou adquirida, tendo freqüentado no passado ou atualmente algum serviço de saúde de atenção à pessoa com deficiência no SUS;

3 - Serão realizadas entrevistas em profundidade, em uma técnica chamada história de vida. Para isso, realizaremos no mínimo 03 encontros, nos quais os sujeitos da pesquisa contarão sua história de vida e aspectos relacionados à deficiência. A duração prevista destes encontros é de uma hora, sendo os mesmos realizados no local de preferência do entrevistado. As entrevistas serão gravadas e posteriormente transcritas, sendo necessário o preenchimento deste termo de consentimento em duas vias (uma para o sujeito entrevistado e outra para o pesquisador).

4 - Há um risco avaliado como mínimo na participação desta pesquisa, pois ela pode causar algum constrangimento ou desconforto na realização da entrevista, que poderão ser sanados através de acolhimento e orientação do pesquisador responsável. 
5 - Os resultados desta pesquisa poderão contribuir para a configuração de novas práticas no campo da atenção à saúde da pessoa com deficiência, uma vez que dará voz aos sujeitos deste processo.

6 - Reitera-se que a entrevista poderá ser realizada no local de preferência do entrevistado, bem como nas datas e horários que ele estiver disponível para tal. Além disso, não acarretará em nenhum custo financeiro ao sujeito da pesquisa.

7 - Em qualquer etapa do estudo, você terá acesso aos profissionais responsáveis pela pesquisa para o esclarecimento de dúvidas sobre os procedimentos, riscos e benefícios, entre outras dificuldades. O principal investigador é a Dra. Marilia Bense Othero, que pode ser encontrada no endereço Rua Dr. Arnaldo, 455 / $2^{\circ}$ andar / Departamento de Medicina Preventiva, e nos Telefones: (11) 3061-7091 (Departamento de Medicina Preventiva FMUSP) / (11) 9981-5920 (celular da pesquisadora). Email: marilia.othero@usp.br.

Se você tiver alguma consideração ou dúvida sobre a ética da pesquisa, entre em contato com o Comitê de Ética em Pesquisa (CEP) - Rua Ovídio Pires de Campos, 225 - 5aandar - tel: 3069-6442 ramais 16, 17, 18 ou 20, FAX: 3069-6442 ramal 26 - E-mail: cappesq@hcnet.usp.br

8 - É garantido-Ihe a liberdade da retirada de consentimento a qualquer momento e deixar de participar do estudo, sem qualquer prejuízo à continuidade de seu tratamento na Instituição;

09 - As informações obtidas serão analisadas em conjunto com outros sujeitos da pesquisa, mantendo-se o nome dos participantes em sigilo.

10 - Você será mantido atualizado sobre os resultados parciais da pesquisa, quando em estudos abertos, e dos resultados finais. Pretende-se divulgar este estudo em eventos e publicações científicas, sempre mantendo seu nome em sigilo.

11 - Em caso de dano pessoal, diretamente causado pelos procedimentos do estudo (nexo causal comprovado), o participante tem direito a tratamento médico no HCFMUSP, bem como às indenizações legalmente estabelecidas.

12 - Comprometemo-nos a utilizar os dados e o material coletado somente para esta pesquisa.

Acredito ter sido suficientemente informado a respeito das informações que li ou que foram lidas para mim, descrevendo o estudo "ATENÇÃO À SAÚDE DA PESSOA COM DEFICIÊNCIA - NECESSIDADES SOB A PERSPECTIVA DOS SUJEITOS”.

Eu discuti com a Dra. Marilia Bense Othero sobre a minha decisão em participar nesse estudo. Ficaram claros para mim quais são os propósitos do estudo, os procedimentos a serem realizados, seus desconfortos e riscos, as garantias de confidencialidade e de 
esclarecimentos permanentes. Ficou claro também que minha participação é isenta de despesas e que tenho garantia do acesso a tratamento hospitalar quando necessário. Concordo voluntariamente em participar deste estudo e poderei retirar o meu consentimento a qualquer momento, antes ou durante o mesmo, sem penalidades ou prejuízo ou perda de qualquer benefício que eu possa ter adquirido, ou no meu atendimento neste Serviço.

Assinatura do paciente/representante legal

Data

Data $1 / 1$

Assinatura da testemunha

para casos de pacientes menores de 18 anos, analfabetos, semi-analfabetos ou portadores de deficiência

Declaro que obtive de forma apropriada e voluntária o Consentimento Livre e Esclarecido deste paciente ou representante legal para a participação neste estudo. 


\section{Anexo E - Diário de Campo}

\section{Dia 01/10/2008}

Entro em contato com Sr. Jair, indicado para a pesquisa pela TO Marta Aoki, que atua na UBS Jardim Boa Vista, a qual foi minha supervisora de estágio em 2004. Fiz contato pedindo indicações por e-mail, ela enviou lista de indicações, sendo escolhido o sr. Jair para a entrevista piloto.

Marta foi até a casa do paciente, estabelecendo primeiro contato, propondo participação na pesquisa.

No contato telefônico, peço para falar com Jair, quem atende é a esposa, dizendo que posso falar com ela. Agendo a entrevista (ela o consulta para saber melhor data): 06/10/2008, segunda-feira, às 10:30h; ela me diz que não preciso confirmar a entrevista. Deixo meu telefone celular para eventual contato.

\section{Dia 06/10/2008}

Vou até o local ( $C O H A B)$, mas tive dificuldade em encontrar o prédio correto; ligo na casa do entrevistado, é a esposa que atende, reconhece meu nome e me diz que esqueceu de minha ida até lá e estava de saída. Pede para que eu agende outro dia, e acabamos combinando para o mesmo dia, no período da tarde (16:00h). [Para mim, fica a questão: quem tem que sair? Ela ou o esposo (o qual eu iria entrevistar)? Volto minha atenção para o fato de que todos os trâmites para combinarmos a entrevista é feito com a esposa, e não com o entrevistado propriamente dito].

Por volta de 15:30h, ligo na casa do entrevistado, confirmado a entrevista (falo com a esposa novamente).

Chego no local às 16:10h, ligo para a esposa novamente, que me recebe na porta do conjunto habitacional. Indica-me o local para estacionar o carro, e me leva até sua casa (muito acolhedora, me coloca embaixo de seu guarda-chuva, protegendo nós duas da chuva que caía). Sento-me na sala, onde estava 
também o neto do casal assistindo televisão. O apartamento é no andar térreo do conjunto habitacional.

A esposa chama o sr. Jair, que estava no quarto. Este vem sozinho do quarto até a sala, estendendo a mão ao se aproximar de mim. Senta ao meu lado, a esposa senta-se na sala conosco, e começo a explicar os propósitos da entrevista e minha ligação com Marta (que os procurou primeiramente).

Leio o termo de consentimento informado em voz alta, para que ele possa acompanhar, e a esposa segue acompanhando com uma cópia em mãos. Sr. Jair disse ter entendido e não ter dúvidas, bem como a esposa. [Enquanto leio o termo de consentimento, percebo que alguns termos poderiam ter sido colocados de forma mais simples, facilitando a compreensão do entrevistado procuro explicar os termos que julgo mais "complicados"]. Ele pede para que a esposa assine por ele, pois "não está mais conseguindo assinar" (sic). Conta-me que na eleição (primeiro turno para prefeito e vereador, ocorrida no dia anterior) precisou colocar a impressão digital, e não assinar o nome.

Antes de começarmos a entrevista, a esposa me pergunta se o neto precisa sair da sala, por conta do barulho da TV; digo que é melhor, mas que não seria obrigatório. Ela pede que o neto vá assistir TV no quarto.

Começamos a entrevista, procuro dizer-lhe para me contar sua história de vida. Conta-me um pouco sobre a infância no Piauí, e a vinda para São Paulo, mas a entrevista só "deslancha" quando ele me conta sobre a aquisição da deficiência.

Tenho que fazer algumas perguntas no decorrer na entrevista, mas vou percebendo que aos poucos ele vai sentindo-se mais a vontade. Os temais centrais são a deficiência, o processo de aquisição da deficiência, os tratamentos que fez.

Ao longo da entrevista, a esposa fica em alguns momentos na sala, em outros faz afazeres da casa e atende ao telefone (que tocou por algumas vezes). Já mais ao final, ela também entra na conversa, e conta um pouco sobre o marido e o tratamento.

Ao longo da entrevista, ele vai sentindo-se mais à vontade, e começa a encostar-se a mim quando fala, e me chamar pelo nome [Infiro que seja um jeito dele aproximar este contato comigo, uma vez que o olhar não é um sentido que ele tenha]. Mesmo quando o telefone toca, ou a esposa anda pela sala para 
conversar com o neto, receber o vizinho na janela, sr. Jair não interrompe a conversa nem por um instante sequer; parece muito concentrado.

Por volta de uma hora de entrevista, tento finalizar, mas é neste momento que ele se abre ainda mais, e me conta por mais meia hora sobre as dificuldades que vem enfrentando no tratamento.

Encerramos a entrevista com cerca de 01 hora e 35 minutos gravados. A esposa me oferece suco, e me dá um pão-de-mel (ela faz doces e salgados para vender).

O Sr. Jair conta-me novamente alguns trechos de sua história (ser atendido por estagiários, sentir-se como cobaia, dificuldade para locomoção). Em algum momento desta conversa, ele me pergunta o que é BRAILE afinal (na entrevista, me contou que amigo sugeriu que ele aprendesse braile, e ele disse não ver muito sentido nisso). Explico para ele que as letras do alfabeto são substituídas por símbolos, sensíveis ao tato; procuro usar o tato para explicar a ele também (tocando em sua perna, ao explicar como seria a leitura em braile).

Combino nosso novo encontro, para a próxima segunda-feira. O casal entra em conflito - o sr. Jair prefere que a entrevista seja feita pela manhã (porque gosta de ouvir um programa de esportes à tarde, na rádio bandeirantes), e a esposa prefere que seja a tarde (afazeres da casa e possibilidade de consulta médica pela manhã). A opinião da esposa acaba por prevalecer; combino que ligarei no domingo, e se não houver consulta para a esposa, irei pela manhã; do contrário, irei à tarde. [Mas, novamente a questão da presença da esposa fica muito forte]. Ele me agradece por ter feito esta entrevista, diz que gostou. [Parece ter possibilitado um espaço de escuta, que ele não teve - ou muito pouco - antes].

Despeço-me e ao levantar, ele me acompanha até a cozinha, segurando em meu ombro para se locomover. Faço um comentário sobre esta locomoção, e ele me diz que em casa consegue se locomover bem, exceto quando alguém esquece a porta da geladeira aberta, ou muda alguma coisa de lugar; ele diz que "aí é briga". Da casa conheci somente a sala e a cozinha; apesar de um tapetinho no chão da cozinha, há um espaço razoável de circulação para o Sr.Jair.

Despedimo-nos novamente; a esposa me acompanha até o carro. Conta-me que ele é um homem muito nervoso, e que na sua opinião ele precisaria de um acompanhamento psicológico. Diz que já tentou na UBS, mas a profissional disse que ele não precisava (segundo a esposa). A esposa ainda fala que agora ele 
melhorou, tem saído mais, mas que é difícil para a família (principalmente ela) acompanhá-lo em tudo. A venda dos doces e salgados é um jeito de distrair-se, segundo ela; também cuida do neto e de dois filhos, que moram com o casal. Ela diz que se não fizesse tantas coisas, não iria agüentar; parece sentir-se sobrecarregada.

Também me agradece, e reitero nosso encontro na próxima semana. Espera que eu manobre o carro, para entrar no apartamento novamente.

$\mathrm{Na}$ entrevista, volto minha atenção para o fato desta ficar muito centrada na questão da deficiência. Talvez por ser um primeiro contato e também pelo tema da pesquisa, ele se volte a estes aspectos. No próximo encontro, buscarei conhecer mais aspectos de sua história de vida propriamente dita (técnica adotada, inclusive).

Noto o quanto me senti constrangida para fazer perguntas pessoais ao entrevistado, sendo a primeira vez que nos encontramos. Talvez o fato de ser um primeiro encontro também o tenha constrangido, influenciando no fato dele se ater mais à questão da deficiência, enquanto uma questão médica, e dos atendimentos que recebeu.

Ainda que demande mais tempo para o campo, uma alternativa possível é fazer um primeiro encontro informal, para conhecer o sujeito, explicar a pesquisa, apresentar o termo de consentimento; e, em um segundo encontro, iniciar a entrevista propriamente dita.

O roteiro demasiado aberto também pode ter sido um influencia. Para o próximo encontro com o entrevistado, farei algumas questões para the perguntar diretamente.

Também penso que formular algumas questões norteadoras da conversa podem facilitar o desenrolar da entrevista (09/10/2008).

\section{Dia 12/10/2008}


Entro em por telefone, no período da tarde, e combino com a esposa novamente o melhor horário para a segunda entrevista; opta pelo período da tarde mais uma vez, por volta das 16:00h.

\section{Dia 13/10/2008}

Hoje chego no condomínio do sr.Jair, por volta de 16:10h, e já estaciono o carro no prédio. Ligo para a esposa avisando que cheguei, e ela vem abrir a porta para mim (porta geral do prédio e porta do apartamento). Sr.Jair já está sentado na sala, esperando-me(?), em companhia do neto. Damos as mãos como forma de cumprimento, e pergunto como foi a semana. Diz que foi bem; também pergunto sobre a consulta médica (havia me dito na semana anterior que teria retorno médico no Hospital das Clínicas). Conta-me que a pressão de seu olho está muito alta, e que o médico lhe receitou alguns exercícios e massagens (sic) para fazer, o que irá ajudar a diminuir a pressão.

Iniciamos a gravação, e procuro orientar nossa conversa para sua vida antes da deficiência visual, sua criação, sua família. Percebo que não estou com o roteiro de entrevista impresso, pois deixei no carro; opto em não ir buscar, e vou guiando a conversa com o roteiro na memória. É uma conversa em que preciso fazer mais perguntas, porém percebo maior facilidade em me contar de sua família. Durante a conversa, volta diversas vezes na questão da perda da visão, o quanto isso o afetou [Infiro que seja uma característica própria daquele que adquire a deficiência ao longo da vida - um dos temas de escolha da amostra da pesquisa, inclusive]. A questão da "desconfiança" com os médicos e com o tratamento também aparece.

Durante toda a entrevista, sua esposa ficou na sala, no sofá ao lado; porém poucas vezes fez comentários. Já no final da entrevista, seu neto senta-se no sofá ao lado da vó, e fica conversando com ela [minha presença na casa está mais natural? Tenho esta sensação]. No decorrer da entrevista, o filho do Sr.Jair sai do banheiro, após o banho, e vai até o quarto de toalha, mesmo comigo na sala [tenho a mesma sensação].

Durante a entrevista, chama-me pelo nome diversas vezes. Fica "pedindo" minha participação na conversa [talvez por não enxergar, meus gestos e 
fisionomia durante a fala não sejam retornos possíveis, devendo eu fazer isso pela fala].

Quando paramos de gravar, me conta que gostaria muito de enxergar (novamente) e que ficou imaginando (nestes dias que se passaram desde a ultima entrevista) como seria meu rosto, minha fisionomia; fez questão de ressaltar que gravou meu nome. Procuro, com ajuda da esposa, fazer uma descrição de minha fisionomia para ele. Quando digo que não aparento a idade que tenho, que pareço mais nova, se identifica com isso e diz que com ele isso também acontece [algo que reafirmo na conversa, pois de fato, ele parece mais jovem]. Pergunto se seus familiares vivem por bastante tempo, ele diz que sim, apenas o pai que morreu jovem, em decorrência de graves problemas cardíacos.

Conta-me que o pai fez uma cirurgia, e que viveu cerca de 5 anos após a mesma. A questão da desconfiança reaparece; ele diz que o coração é algo que não se deve mexer e que talvez seu pai tivesse vivido mais se não tivesse operado. A esposa entra na conversa e diz que era uma doença muito grave, e que ele morreria se não tivesse feito a cirurgia. Sr.Jair não se dá por vencido, e na confia muito nesta intervenção; associa ao seu problema de visão, dizendo que sempre imagina que se não tivesse feito a primeira cirurgia, talvez estivesse enxergando um pouco ainda [fato importante para compreender esta relação com a deficiência e com os médicos/profissionais de saúde].

Procuro responder que devemos fazer o que acreditamos ser melhor naquele determinado momento; e que se ficarmos pensando "e se?, e se?" é muito angustiante. Ele concorda; após breve silêncio, nos despedimos. Combinamos de nossa ultima entrevista ser na próxima segunda-feira, e que ligarei no domingo para confirmar; pergunta à esposa se terão alguma programação neste dia e ela diz que não. Pergunta se não me atrapalhará ligar no domingo, digo que não, e que quem pode estar atrapalhando sou eu, em relação a eles. Ele diz que não, que é um prazer receber-me para conversar.

Despedimo-nos novamente, a esposa me leva até o carro, abrindo o portão do condomínio para mim.

Fico pensando o quanto a aquisição de uma deficiência é uma imensa e intensa ruptura na vida do sujeito e de sua família; ao vivermos nosso cotidiano, não concebemos que podemos ser acometidos por alguma doença ou acidente que nos faça perder nossas capacidades (até para conseguir viver). A deficiência como "tragédia pessoal" , como trazem alguns autores, é passível de 
compreensão; apesar de acreditar que, com ajuda e com o tempo, conseguimos nos adaptar e tirar lições de aprendizado diante desta situação (e como muitas pessoas com deficiência relatam, não querem retornar ao seu "estado anterior" não é o caso do entrevistado).

\section{Dia 19/10/2008}

Entro em contato novamente pelo telefone, no final de tarde. Pergunto pela esposa (entendo que é com ela que os combinados são feitos - parece-me "a senha"). Quem atende o telefone é o Sr.Jair, que me reconhece; diz que está tudo certo para a entrevista, e quando pergunto o melhor horário, consulta a esposa. Optam em manter o mesmo horário: por volta de 16:00h.

\section{Dia 20/10/2008}

Hoje, na data da entrevista, saio atrasada para ir à entrevista (pendências em meu local de trabalho); opto em não ligar avisando, porque seria um atraso pequeno (no máximo quinze minutos). Chego com cerca de 15 minutos de atraso, e o sr.Jair está na garagem (me esperando?, pergunto-me). Abro o vidro do carro e falo com ele, avisando que sou eu a chegar. Ele me recepciona calorosamente, e pergunta se atrasei devido transito; explico sobre meu atraso no trabalho. Ele me acompanha até seu apartamento; de fato, estava me esperando, e quis ir até a garagem para me esperar. Até chegar em seu apartamento, ele me acompanha com uma das mãos em meu ombro; na porta da casa, identifica com facilidade a chave correta em seu chaveiro e abre a porta. [Comento como ele abre com facilidade].

No inicio da entrevista, procuro pontuar que este é nosso ultimo encontro [por ter aberto este espaço de escuta, acho importante reforçar este fechamento, retomando o contrato que fiz com ele e meus motivos de estar ali].

Alguns fatos chamam minha atenção durante a entrevista:

- Parece não querer finalizar os assuntos, sempre lembra de novas histórias para contar [vínculo maior comigo? Fato de ser a última e adiar a perda (?) deste espaço?]; 
- Traz diversas histórias de pessoas com deficiência que conhece e/ou convive. Conta também que teve uma incapacidade grave na mão, resultado de queimadura por acidente de trabalho, ficando três meses afastado e fazendo fisioterapia [Penso como não é o primeiro contato dele com a incapacidade e a dependência];

- Em alguns momentos, troca a palavra cemitério por hospital [Sentido de sofrimento que tem para ele - um dos motivos de querer ser atendido rápido, inclusive].

- Nas três entrevistas, a esposa esteve na sala, junto conosco. Hoje ela sai para atender a porta, e demora um pouco conversando fora do apartamento. É o momento em que ele me conta que às vezes chora sozinho, pelas dificuldades que vem enfrentando, e que é muito vaidoso e gosta de se vestir bem e ser elogiado [presença da esposa tem sua influência];

- No decorrer da entrevista ele também fala de como o Hospital das Clínicas é cheio e o atendimento demora; pergunta se eu conheço o ambulatório de oftalmologia. Coincidentemente (?), fui até lá na última sexta-feira (17/10), para entregar algumas coisas à uma amiga de minha família que ali trabalha como auxiliar de enfermagem. Neste dia, chamou-me a atenção o número de pessoas esperando, o calor que fazia nos corredores e nas salas; fico pensando o quanto as pessoas que ali estão esperando pela consulta devem ficar irritadas, pois eu ficaria se ali estivesse. É exatamente o que ele traz na entrevista, da irritação com a demora e também com a questão do calor (que é alias o jeito que ele percebe a quantidade de pessoas, uma vez que ele não enxerga).

Assim que finalizamos a gravação, a esposa me traz um bolo (já cortado e no prato) [na primeira entrevista, me ofereceu bolinhos e recusei; hoje não deu espaço para recusa - é a sensação que tenho].

É também depois de ter terminado a gravação que o Sr. Jair me pergunta onde moro; quando digo, me conta que jogou futebol de rapaz em clube perto de minha casa (Pelezão); me conta que morou na Vila Anastácio e que trabalhava na Lapa (Rua D.João V). Vamos trocando experiências sobre a Lapa, que também conheço. Conhece o colégio que estudei (Campos Salles) e outros colégios da Lapa - seus filhos estudaram também no bairro. Conta que ia a pé 
da Vila Anastácio ao trabalho, e que passava pelo pontilhão (local perto da casa de meu avô, que também comento). Comenta do quartel que tem ali perto, do quando o bairro mudou, e como ele gostaria de voltar a morar lá ou, e principalmente, na Vila Mangalot, onde morou depois dali. Queria morar numa casa, com espaço e jardim.

O casal me conta que o apartamento está apertado, pois tem dois filhos e um neto que moram com eles. Contam-me da separação do filho e da esposa, e da vinda do neto para a casa, além das dificuldades de relacionamento. Ao falar do neto, Sr.Jair relembra seus tempos de escola, em Teresina, onde estudava em colégio dos padres capuchinhos e tinha palmatória; não gostava muito de estudar em casa, mas prestava atenção às aulas. Relata que não é um avô que paparica, pois briga muito com o neto, não tem paciência; que é a avó quem paparica o neto. Também não concorda com alguns aspectos da criação do filho para com o neto.

Esposa fala de sentir-se sobrecarregada por ter que cuidar do neto, porque ela já tem um "problemão" (referindo-se ao Sr.Jair) - ele percebe isso, e diz que ele a atrapalha. Ela me conta da viagem que fez este ano para o Nordeste, e que o filho tirou férias para cuidar do pai; ela diz que se não fosse assim "o mandaria para a casa das irmãs" (referindo-se ao Sr.Jair) - [questão da dependência e falta de autonomia fica muito forte para mim].

O Sr.Jair me agradece pela entrevista, disse que foi bom conversar e distrair e que quer ser convidado para alguma palestra que eu fizer. Nos despedimos; reforço que estou à disposição, e que podem me ligar se tiverem dúvidas ou precisarem de alguma coisa relativa à pesquisa. Hoje a esposa não me leva até o carro (pois está frio, segundo ela) - [minha presença mais natural na casa, é a impressão que tenho]. Volta depois, entretanto, pois se lembrou de abrir o portão; como eu já tinha aberto, ela fica me observando - junto com o neto até eu ir embora.

\section{Dia 20/03/2009}

Tento contato com próximo entrevistado, Ricardo, novamente indicado pela terapeuta ocupacional Marta Aoki, que trabalha na UBS Boa Vista. Ricardo é militante do movimento das pessoas com deficiência, segundo ela. Ela fez um 
primeiro contato com ele por telefone, e com seu aceite em participar da pesquisa, ela repassou o contato para mim.

Tento ligar para já há vários dias, em um horário pré-determinado (ele pede que eu telefone entre 12:30h e 13:30h), porém em todas as tentativas cai na caixapostal.

\section{Dia 24/03/2009}

Tento um novo contato com Ricardo, em outro horário, e ele me atende. Explico a pesquisa, e ele pergunta se é para algum jornal ou programa de televisão; digo que é uma pesquisa acadêmica, para mestrado, e detalho a metodologia (história de vida, em três encontros). Ele tem disponibilidade em seus horários de almoço; me conta que trabalha em um Centro de Atendimento ao Trabalhador, no bairro da Lapa.

Coloco-me a disposição para os finais de semana, mas ele diz que prefere durante a semana, pois tem outras atividades e compromissos. Marcamos então para esta mesma semana, no dia 27/03, no meio de seu horário de almoço, em seu local de trabalho. Ele foi receptivo, porém ao mesmo tempo distante, talvez até desconfiado [Essa é a impressão que tenho logo após desligar o telefone].

Depois de ter agendado com ele, fico pensando que é pouco tempo disponível para a conversa (meia hora), o que prejudicará o desenrolar da entrevista. Fico apreensiva, e decido colocar para ele no dia que será necessária uma outra organização, e que se ele não estiver disponível, deixaremos para uma outra oportunidade.

\section{Dia 27/03/2009}

Chego alguns minutos mais cedo do que agendado (13:00h). Pergunto pelo Ricardo na recepção, e fico aguardando. Observo que é um local quente e um pouco apertado; são muitas cadeiras e muitas pessoas para serem atendidas; parece-me que é um local de encaminhamento de pessoas ao trabalho.

Sou chamada a ir ao fundo do local, onde encontro uma senhora que me leva até o Ricardo. Entro por uma porta restrita aos funcionários, passo pela copa e 
vou até a sala onde ele trabalha. Ele está terminando de almoçar e logo vem ao meu encontro. Ele é cadeirante, usa luvas para tocar a cadeira. [Fico apreensiva em como cumprimentá-lo, pois não sei qual seu grau de limitação física - será que ele tem total amplitude de movimento nos braços? Estranhamento...] - ele estende a mão para mim, se posiciona e sua mesa e começamos a conversar.

Retomo a questão da pesquisa e seus objetivos, bem como a metodologia. Quando vou abordar a necessidade de encontros mais longos, ele me disse que ficou pensando sobre isso e se propõe a me receber em sua casa, no sábado. Apenas não sabe se será amanhã, pois talvez terá uma atividade do conselho da pessoa com deficiência.

Combinamos então de fazer dois encontros em seu local de trabalho (hoje e mais um) e um encontro em sua casa. Apresento-lhe o termo de consentimento informado, que ele lê com calma e me faz algumas perguntas. [Presto atenção no termo de consentimento, e observo que no caso de pessoas com deficiência, é necessária a assinatura de uma testemunha. Fico com a idéia do estereótipo, do preconceito com relação à pessoa com deficiência - uma pessoa com deficiência física é plenamente capaz e responsável por seus atos. No caso de uma incapacidade de assinar, poderíamos pensar na necessidade de uma outra pessoa, mas não é o caso. Opto em somente ele assinar].

Em um determinado momento, digo-Ihe que se abordarmos algum assunto que ele não queria falar, é só dizer e interrompemos; ele pergunta se quando isso acontecer, se ele poderá retomar o assunto depois. Com relação ao risco de constrangimento da pesquisa, ele associa ao fato de outras pessoas ouvirem a conversa. [Fica claro o local de realização da entrevista interfere muito - ali é um local de trabalho, há outras pessoas compartilhando a sala com ele, e não há total privacidade para que o entrevistado faça seu relato].

Após isso, iniciamos a gravação. Ele me conta da infância e da adolescência preenchidas pelos tratamentos; me chama a atenção que ele diz ter optado parar com tratamentos "porque queria viver" (sic). Também fala do alcoolismo, mas percebo que baixa o tom de voz para falar isso. Aborda o trabalho, um pouco da história da família.

Devido ao tempo (já eram 13:25h, passaram-se os trinta minutos e ele deveria retornar ao trabalho), interrompo a entrevista. Ele terá a resposta sobre sua disponibilidade para amanhã no final da tarde, e combinamos que ele me ligará por volta das 18:00h confirmando. 
Ele me acompanha até a saída do local, pois quer ir ao sanitário. Não há barreiras de acessibilidade no percurso de sua sala até o sanitário, mas pelo grande número de pessoas, ele tem que desviar de muitos obstáculos, e pedir para que as pessoas dêem licença para passagem.

Nos despedimos, e ele reitera que entrará em contato no final do dia (combinamos que ele dará um toque em meu telefone e eu retornarei a ligação custos, provavelmente).

As 18:00h ele me liga, eu retorno e combinamos nossa entrevista para amanhã, as 08:00h, em sua casa. Ele é bastante meticuloso, me explica onde mora, que terá outras atividades e por isso precisaríamos nos encontrar logo no primeiro horário da manhã. Disse que irá ficar atento a minha chegada, pois mora nos fundos de uma outra casa.

\section{Dia 28/03/2009}

Chego na casa do Ricardo no horário combinado.Ele estava vindo de sua casa, para colocar o lixo na rua. Abre o portão para mim, e ficamos um pouco na frente da casa, conversando com um vizinho que passeava com a cachorra. 0 vizinho conta que a cachorra "segue" os barulhos da cadeira de rodas, quando Ricardo anda pelo quintal.

Entramos na casa, e ele faz questão que eu vá na sua frente. Ele mora nos fundos, há um bonito jardim entre as duas casas. Entramos na sala; não há muitos móveis, muitas coisas estão empilhadas. Ele me mostra que limpou a mesa, e separou um local para que pudéssemos conversar. Ressalta também que não tem costume de receber pessoas em casa, que a "vida é lá fora". [Penso na importância do espaço de escuta - abriu sua casa para mim, preparou o ambiente para que pudéssemos conversar - ou seja, parece que a escuta genuinamente interessada, ainda que para a pesquisa, é algo valorizado pelo entrevistado - e também pelo entrevistado anterior (Sr.Jair)].

Antes do início da gravação, ele retoma a insatisfação com o trabalho, pois a equipe terá que mudar para a unidade da Luz, e lá não há condições de acessibilidade para ele, bem como não terá o transporte da prefeitura (ATENDE) disponível. Conta que já saiu de outros empregos pelo mesmo motivo. Fica muito preocupado e ansioso com estas questões, segundo ele; ele irá sair de 
férias na próxima sexta-feira, e seu supervisor orientou para que ele descanse e retome este problema na volta.

Enquanto íamos até sua casa, observo que ele está em outra cadeira de rodas e que ele não está usando as luvas, como no dia anterior. Isso irá aparecer em seu relato posteriormente, pois precisa de uma cadeira de rodas mais leve (e a utiliza para trabalhar) e usa as luvas por conta da sujeira das ruas. Volto minha atenção também para o fato dele estar usando pantufas de urso [Está a vontade com a minha presença?].

Quando entro na sala, observo também que há uma estante, com muitos objetos. Em seu relato, ele irá destacar a importância da oficina de mosaico que participou em uma unidade de saúde, e me mostra uma das suas produções, que tem local de destaque nesta estante. Por alguns anos, sua renda vinha da produção de artesanatos.

Durante sua fala, retoma a situação vivida ontem [que observei, e também chamou minha atenção] de ter que pedir licença para passar. Em todo o encontro (que teve duração de aproximadamente duas horas), percebo o Ricardo como alguém tímido e extremamente metódico. Remeto esta observação a um trecho de seu discurso em que ressalta ter tido que amadurecer muito cedo.

Ao final da entrevista, Ricardo reforça o fato de estar à disposição para esclarecer dúvidas por telefone, se eu precisar de mais informações ao longo da pesquisa. Marcamos nosso próximo e último encontro para a próxima terça-feira, novamente em seu local de trabalho.

\section{Dia 31/03/2009}

Ricardo já está me aguardando quando chego no horário combinado. Novamente me apresento na recepção, mas logo sou encaminhada à sala dele; o recepcionista diz que ele já me aguardava.

Ele estava trabalhando no computador; neste encontro, irá almoçar após nossa conversa. Logo no início, retoma as dificuldades no trabalho e sua decisão de tirar férias e resolver isso ao retornar. Trouxe também um livro de charges sobre preconceito em relação a pessoas com deficiência; conta que já viveu muitas situações que estão ali. Digo que veremos o livro após a entrevista. 
No seu discurso, três aspectos chamam minha atenção:

- Diz que a cadeira de rodas é como uma extensão de seu corpo; não gosta que as pessoas encostem-se a ela, apóiem seus pés nas rodas, usem-na como apoio. Por outro lado, diz que não se reconhece quando se vê no espelho de uma vitrine, por exemplo - parece que só se lembra que é cadeirante nestes momentos, e que isso causa estranhamento. Acha que isso ocorre por "problemas psicológicos" (sic).

- O medo é um sentimento que (re)aparece no seu relato [Foi um aspecto importante da entrevista anterior]. Medo de cair e se machucar, por exemplo. Há limitações que são decorrentes do medo. Ricardo fala: "Eu sou medroso mesmo..." (sic).

- Reforça mais uma vez sua disponibilidade para eu entrar em contato se precisar ao longo da pesquisa [Quer relacionar-se com as pessoas? Entende a pesquisa como um dever para as pessoas com deficiência, como ir no encontro de acessibilidade (citado na primeira entrevista)?].

Durante a entrevista, somos interrompidos por uma colega de trabalho, que gostaria de falar com o Ricardo; ele explica que está ocupado, dando uma entrevista para uma pesquisa, e ela diz que pode aguardar, pois não era nada importante. [Na posição que eu estava sentada, não a vejo mais após este diálogo. Quando me levanto, no final da entrevista para ir embora, vejo que ela está sentada atrás de nós, e ficou lá esperando o término, ouvindo tudo o que foi dito - Atento-me para isso: curiosidade? Interesse?].

Após a gravação, juntos nós vemos o livro de charges trazido por ele. São diversas situações de preconceito enfrentadas pelas pessoas com deficiência. Ricardo aponta algumas experiências que passou:

- Taxista não aceita-lo, pois não cabia a cadeira de rodas no carro;

- Situações envolvendo sexualidade da pessoa com deficiência: "Um cadeirante pode fazer sexo?", "Uma pessoa sem deficiência não deve namorar uma pessoa com deficiência, pode estar abusando, é 'tarado'";

- Obstáculos que impedem a circulação por espaços públicos e privados: escadas, degraus, buracos;

- Pessoa com deficiência vai pedir uma informação a alguém, que não a ouve, e Ihe dá uma esmola. 
Também comentamos sobre a REATECH (Feira Internacional de Tecnologias em Reabilitação, Inclusão e Acessibilidade), que ocorrerá no próximo final de semana (03, 04 e 05 de abril) em São Paulo. Ricardo disse que irá participar, e pergunta se já fui. Digo que vou todos os anos, mas que tenho a impressão de ser uma feira voltada ao consumismo e ao mercado das tecnologias; comento que as montadoras de automóveis têm estandes cada vez maiores.

Ricardo concorda comigo, diz que também tem esta impressão. Acrescenta que isso traz dificuldades para a pessoa com deficiência, pois a maior parte delas não tem condições financeiras de adquirir todos aqueles produtos, carros, equipamentos.

Finalizamos a conversa, nos despedimos. Ele agradece e reitera sua disponibilidade para mais informações ao longo da pesquisa. Fica na sala, e vou embora.

\section{Dia 25/05/2009}

Como pedi indicações de pessoas a serem entrevistadas na pesquisa para uma colega fisiatra (Dra. Liliana), que trabalha no centro de reabilitação (DMR UMARIZAL), ela sugeriu que eu fizesse uma visita à unidade, conhecesse o espaço e ela me colocaria em contato com a enfermeira-chefe, para a tal indicação.

Ao chegar no serviço, esta colega estava em reunião de equipe, e entro para acompanhar esta atividade; sento-me em uma cadeira afastada da mesa de reunião (onde estavam diversos profissionais) e fico observando por cerca de 30 minutos, até o final do encontro.

Estavam participando uma médica (esta colega), uma fonoaudióloga, uma fisioterapeuta, uma terapeuta ocupacional, uma nutricionista, duas psicólogas, uma assistente social, uma enfermeira e uma pessoa responsável pelo condicionamento físico (educadora física?). Fiquei refletindo sobre a dinâmica da reunião: a médica coordenava, a partir de um prontuário de um paciente, e cada profissional relatava o que estava sendo realizado e os ganhos adquiridos com a reabilitação. 
Naquele momento, ainda que seja um mínimo recorte que presenciei, volto minha atenção para o fato de que cada um fala somente "do seu pedaço", especialmente focado no corpo e na funcionalidade (modelo bastante tradicional de centros de reabilitação, segundo literatura). A escolha dos casos a serem discutidos também é feita por diagnóstico: esta era uma reunião dos "hemileve", ou seja, pacientes com hemiplegia leve.

Sinto falta da história do sujeito: quem é, de onde vem, onde está, o que faz, o que gosta, o que não gosta, o que quer, o que espera... Fico me perguntando se isso aparece em outros momentos de discussão em equipe. Por outro lado, a reunião "rende"; nos trinta minutos que ali fico, são "discutidos" (será que discutiu-se mesmo?) três casos.

Penso ainda que este jeito de discutir os casos pode revelar uma postura de manutenção de certa distância entre o profissional e o paciente; trabalho em um serviço que estamos o tempo todo discutindo as histórias, as dificuldades e os desejos dos nossos pacientes, mas nos questionamos se nos envolvemos "demais". E, ainda, não conseguimos fazer reuniões: em uma hora, discutimos um caso.

Depois da reunião, vou com minha colega conhecer a unidade, que atende em grupos (especialmente devido ao número de pacientes que precisam de acompanhamento - ampliação de cobertura) e alguns atendimentos individuais. Liliana apresenta-me à enfermeira, Melina, e explica um pouco sobre a pesquisa e minha necessidade; explico um pouco mais detalhadamente, e peço que ela indique uma informante do sexo feminino (pelas demandas do processo da pesquisa). Muito solicita, ela entra em contato com a filha de uma paciente, que estava ao lado do local onde conversávamos (esperando? Passando?); esta filha aceita. Me apresento, explico a pesquisa, e ela me leva até sua mãe, que estava no andar térreo; no percurso, ela me conta que a mãe tem "um pouco de dificuldade na fala".

Quando conheço esta mãe, me apresento, e observo que ela tem uma dificuldade bastante importante na fala. Ela parece compreender o que the é dito, mas consegue balbuciar alguns sons somente. Ela acena sim com cabeça quando pergunto se participaria, mas ao perceber sua dificuldade, digo-lhe que será muito cansativo e que deixaremos para uma outra oportunidade (mais jargão impossível - quis ser gentil). 
Volto para conversar com a enfermeira, e explico melhor e mais detalhadamente os critérios. Ficamos de entrar em contato via telefone no final do dia, pois ela iria procurar alguém que pudesse/se interessaria em participar.

Ao ir embora, fico pensando na senhora que fiz este primeiro contato. Quanta dificuldade não poder se comunicar... que angústia ela deve sentir (e aqueles que querem se comunicar com ela também, inclusive eu)... Pensando sobre necessidades de saúde de pessoas com deficiência, as questões de comunicação devem estar em pauta - a chamada comunicação alternativa. Acessibilidade para além do físico/arquitetônico também... Fico com esta questão para ser trabalhada na reflexão/análise da pesquisa...

Com relação à entrevista, tento contato com a enfermeira Melina, sem sucesso. Através do contato com a médica Ana Silvia Dalmaso, recebo a indicação de um senhor com poliomielite para ser entrevistado. Não consigo contato telefônico, e com isso, vou - neste mesmo dia - até a unidade de saúde na qual ele trabalha.

Noto que estou bastante ansiosa, ainda que já tenha sido feito um contato prévio por esta colega/professora médica. [Percebo que o primeiro contato com os entrevistados causam-me bastante ansiedade. Será que de fato estão disponíveis para esta conversa? O que sentem ao serem "pesquisados"? ou algo $\operatorname{assim} . .$.

Encontro-o facilmente, porém ele não se encaixa: teve a doença com 09 meses (caracterizando def.congênita), porém já fiz entrevista com informante neste perfil. Pergunto se ele conhecesse alguém, e ele indica uma amiga; dispõe-se a entrar em contato com ela, e nos falaremos por telefone daqui uns dez dias.

\section{Dia 26/05/2009}

A médica Ana Silvia entra em contato comigo pelo telefone, com uma nova indicação (pessoa com deficiência auditiva), deixa seu telefone comigo. Entro em contato no inicio da noite (18:00h, aproximadamente), sem sucesso.

Enfermeira Melina entra em contato comigo: conseguiu uma pessoa para ser Fátima, e já agendou com ela os três encontros, que serão realizados no próprio 
centro de reabilitação nos dias 05/06, 19/06 e 26/06, em um horário de espera entre terapias.

\section{Dia 29/05/2009}

Consigo contato telefônico com a pessoa com deficiência auditiva indicada, Sra. Cristina. Primeira entrevista será na próxima semana, segunda-feira, dia 01/06, em seu local de trabalho.

\section{Dia 01/06/2009}

Chego ao Centro de Saúde preocupada em reconhecer Cristina; no telefone, quando agendamos a entrevista, ela disse recordar-se de mim, porém não lembro-me dela. Quando a procuro e a vejo, a lembrança é imediata. Foi uma profissional com quem tive bastante contato no período em que estive trabalhando (aprimoramento) neste Centro de Saúde.

Ela estava terminando de atender uma paciente, mas rapidamente vamos a um consultório para conversarmos. O serviço está em greve, havendo um movimento pequeno de pessoas.

Explico novamente a pesquisa e entrego o termo de consentimento. Ela lê muito rapidamente [confiança em mim, por já me conhecer? Está acostumada com a questão da pesquisa, pelo serviço em que trabalha]. Ao iniciar a entrevista, procuro fazer uma pergunta bastante aberta, mas ela traz para a história de sua deficiência auditiva logo no primeiro momento [assunto muito "marcante"? Tema da pesquisa? Ambos?].

Durante a entrevista, emociona-se bastante, chorando por muitas vezes. Procuro acolhê-la, mas preocupo-me como será para ela em possíveis momentos de encontro para além da entrevista, no contexto de trabalho, afinal está dividindo experiências pessoais bastante emocionantes.

Ao longo do seu relato, chama minha atenção o fato dela se "subestimar", em suas próprias palavras. É algo que ela própria aponta, mas havia chamado minha atenção.

Depois da gravação, continuamos conversando por um tempo e ela me pergunta sobre as pessoas que já entrevistei. Ao falar sobre o senhor com deficiência 
visual, ela comenta o quanto deve ser difícil ter este tipo de deficiência, pois a pessoa não consegue enxergar nada e terá muita dificuldade em locomover-se pela cidade. Comenta ainda que é preciso "coragem" - palavra utilizada pelo senhor entrevistado ("Falta coragem para sair na rua", ou algo assim).

Cristina fala ainda sobre a segregação das pessoas com deficiência, diz que com qualquer tipo a pessoa é um pouco segregada. Comenta que as pessoas as vezes não querem repetir o que ela teve dificuldade de ouvir. Conta a historia de uma paciente que tinha um filho surdo, e que não queria que ele fizesse uma cirurgia (se assim houvesse possibilidade - hipoteticamente) - pois ele vivia em seu "próprio mundo".

Acho importante comentar também que nunca havia percebido que ela tinha deficiência, ou usava aparelho auditivo. Durante a entrevista, comentei isso com ela; até porque ela mencionou ter relutado em usar o aparelho, por vergonha (tema que também apareceu na entrevista com o senhor com deficiência visual).

Saio da entrevista pensando na questão da evolução das doenças crônicas/progressivas e a aquisição de deficiências. O estereótipo do deficiente é o cadeirante, mas há muitas situações de progressão de doenças que levam a deficiência, e é muito importante considerar isso.

Marcamos nosso próximo encontro para a próxima semana, também na segunda-feira, no mesmo horário (09:00h).

\section{Dia 08/06/2009}

Chego no local combinado, uns dez minutos atrasada. Ela estava falando ao telefone, na área externa da unidade (UBS que trabalha). Aguardo-a e subimos para uma sala.

No caminho, ela me conta que ficou pensando sobre o que falaríamos hoje, já que na entrevista anterior ela "já chorou todas as suas pitangas para mim" (sic). Eu também estava ansiosa com relação a isso: por ser um assunto aparentemente tão difícil, será que ela traria mais coisas em nossa nova entrevista? Preparei-me anteriormente, programando começar a entrevista perguntando sobre sua infância e adolescência. 
Assim o faço - e ela novamente traz conteúdos bastante difíceis de sua história de vida. Pergunto sobre as coisas boas, procurando reforçar este aspecto, mas ela menciona pouco e logo volta a me relatar passagens difíceis de sua história de vida.

Ao longo da entrevista, conta-me diversos outros momentos de sua vida, um pouco mais sobre sua família, e voltamos muitas vezes às questões relacionadas à deficiência. Volto minha atenção para seu movimento de não fazer tratamento/acompanhamento, para não pensar no assunto [negação]. Valoriza, como os outros dois entrevistados anteriores, a necessidade de apoio e escuta para a pessoa com deficiência.

Ao final da entrevista, procuro ressaltar a questão do sigilo, especialmente por eu freqüentar a unidade que trabalha em contextos para a própria pesquisa e o mestrado e outros momentos de trabalho. Ela diz que sabe da minha ética [me conhecer anteriormente fez a diferença para compartilhar sua história?]. Revelase surpresa por ter contado tantas outras coisas, uma vez que anteriormente estava preocupada sobre o que iria falar.

Despedimo-nos com um abraço muito forte [valorização do espaço de escuta] e também conversamos sobre como a pesquisa tem sido uma experiência enriquecedora e de muito aprendizado, a partir dos relatos das pessoas.

Marcamos nosso próximo para a próxima semana, na quinta-feira, no mesmo horário e local.

Hoje, ela sai da sala em que estávamos antes de mim. Fico guardando meus papéis e materiais, e saio depois. Encontro-a na saída, onde participava de uma pequena reunião de funcionários em local próximo. Saio devagar para não atrapalhar, não converso ou despeço-me dela novamente [preocupada com a questão do sigilo].

\section{Dia 19/06/2009}

Vou para a primeira entrevista na DMR. Sei que a pessoa que entrevistarei chama-se Ângela, mas não tenho outras informações. Fico ansiosa e também preocupada, pois a enfermeira que "escolheu" o sujeito. Ao chegar, procuro pela Melina (enfermeira), que estava na sala da enfermagem. Ela me reconhece, lembra-se da entrevista e de nosso combinado. 
Ângela estava na sessão de fisioterapia (cheguei antes do horário combinado). Aguardo-a. Ela procura pela enfermeira, que nos apresenta. Vamos até uma sala, indicada também por Melina. Junto com Ângela está sua sobrinha Roberta, que participa da entrevista.

No primeiro momento, lemos o termo de consentimento juntas. Com termos difíceis, vou explicando passo a passo cada item descrito. Ângela aceita a entrevista, mas avisa que fala pouco, que não gosta de falar. Reitero que a pesquisa não tem vinculação com o serviço de reabilitação, nem acarretará qualquer modificação em seu plano de cuidados pela equipe a atende.

Quando ligo o gravador e inicio perguntando sobre sua história, Ângela conta bastante. Começa pela doença e pelo diagnóstico [tema da pesquisa?]. Tenho que ser mais ativa, perguntar mais, interagir, mas Ângela é bem receptiva e conta muito sobre sua história. Fala, inclusive, que gosta muito do tratamento em Terapia Ocupacional que realiza. [Penso que isto pode ter sido uma influência no aceite em participar da pesquisa].

A sobrinha intervém em alguns momentos, mas pouco. Ângela pergunta sua opinião em alguns momentos. Em uma ocasião, em que a sobrinha sai da sala por alguns minutos, Ângela comenta em voz baixa que sentiu vontade de morrer, por conta de sua doença e diagnóstico. [Privacidade].

Toda a entrevista dura aproximadamente 40 minutos. Ao final, surpreende-se por ter conseguido falar. Roberta (sobrinha) conta que a família ficará surpresa, pois "ela não é de falar"(sic). [Por que será que falou? Espaço genuíno de escuta?].

Combinamos nosso próximo encontro; retomo que ainda faltam duas entrevistas para finalização. Ela me agradece e nos despedimos.

Antes de ir embora, faço questão de ir ao encontro de Melina (enfermeira), para agradecê-la pela ajuda. Aproveito e reforço que ocorrerão mais dois encontros, já agendados com Ângela, sempre às sextas-feiras.

\section{Dia 22/06/2009}

Alteramos a data do último encontro com Cristina para hoje. Ligo confirmando, e ela me diz que iria entrar em contato desmarcando [Coincidências...]. Quando 
chego na unidade para a entrevista, ela está atendendo; diz que iria me ligar para desmarcar novamente, mas não conseguiu [Fugindo da conversa? Resistência?]. Colega irá permanecer em sua função enquanto conversamos.A greve que o serviço vem enfrentando é o tema de nossa conversa até o local da entrevista propriamente dita (um dos consultórios da UBS).

Antes de iniciarmos a gravação, meu medo se concretiza por alguns instantes: tenho problemas para ligar o gravador, não consigo encontrar novas pilhas. Apesar da apreensão inicial, consigo encontrar as pilhas nos meus materiais, e iniciamos a entrevista gravada.

Procuro focar neste encontro a vida dela, para além da saúde [encontro pós qualificação do mestrado, e a banca apontou enriquecimento das entrevistas ao ampliar aspectos questionados aos sujeitos]. Cristina relata longamente o processo de adoecimento da mãe e toda a organização da sua vida na árdua tarefa de cuidar (na família, no emprego, nos animais). Evangélica, conta também uma passagem de Abraão, que põe o filho a sacrifício, identificando-se com esta metáfora. Resignação e sacrifício. [Penso que vale a pena conhecer mais esta história]. Cristina chora muito quando falamos dos projetos para o futuro. Para ela, as pessoas com deficiência precisam de trabalho, produção, dignidade. [E, portanto, para além da saúde].

No final da entrevista, já com gravador desligado, Cristina me agradece muito pelo espaço que proporcionei, disse que "foi uma terapia" (sic). Agradeço a participação dela na pesquisa, e reitero que enviarei a história editada para apreciação, bem como sugestões e modificações que ela achar necessário. Reitero ainda a questão do sigilo.

Ao sair da entrevista, vejo na UBS um pôster de um dos profissionais da equipe (provavelmente apresentado em algum congresso) sobre o tema das necessidades - e muitas estão para além da saúde. Isto chama minha atenção, especialmente neste momento pós-qualificação.

\section{Dia 03/07/2009}

Vou para a segunda entrevista com Ângela; não ligo confirmando, fico apreensiva. Espero na sala de enfermagem, fazendo contato com o profissional para que chamem Ângela. 
Hoje ela está com outra acompanhante; pergunto quem é, e ela me responde que é sua irmã Rosa. Vamos para a entrevista em uma outra sala, hoje sem mesa entre nós [diminuindo nossas distâncias, em todos os sentidos]. Ângela entra sozinha hoje, mas antes conversa com outra profissional ali perto. Inicia nossa conversa contando das novidades dos últimos quinze dias.

Na gravação propriamente dita, alguns aspectos chamam minha atenção:

- Nesta sala, há muito barulho, especialmente vindo da rua e da escola em frente. Durante a fala de Ângela, tenho que interromper e levantar para fechar as janelas [poderia ter atentado para isso antes, preparando melhor o ambiente da entrevista].

- Ângela fala muito, conta muito sobre si, apesar de dizer que não costuma falar [Quantos espaços reais de escuta teve antes?].

- Nos seus relatos, ressalta a dificuldade com a questão do futuro, a necessidade das pessoas com deficiência se ocuparem, e dos benefícios que a doença também trouxe a ela - "Males que vem para bem..." (sic). [Penso no livro de Oliver Sacks, Um Antropólogo em Marte, que trata dos paradoxos da doença].

- Também menciona a questão da superproteção e do preconceito que vivencia. Diz que o Brasil não está preparado para os deficientes. Aborda a necessidade de medicamentos e insumos, e as dificuldades para consegui-los.

- Como outros entrevistados, também consulta-se com médicos pelo sistema privado (convênio), e - pasmem! - é o mesmo médico nos dois âmbitos.

Ao finalizarmos a entrevista, agendamos nosso próximo encontro para daqui quinze dias, pois haverá um feriado na próxima semana. Ângela preocupa-se com a data, pois está na iminência de ter alta do serviço de reabilitação; digo que, se assim for, posso ir até sua casa para finalizarmos as entrevistas. Combinamos que ela entrará em contato por telefone, se necessário.

Aos nos despedirmos, Ângela pergunta meu nome novamente. Não dá mão, beijo ou abraço para a despedida. Apesar disso me causar estranhamento, respeito o movimento dela, e também me despeço à distância.

Penso que seria bom eu ligar confirmando e relembrando nosso próximo encontro, daqui duas semanas. 


\section{Dia 17/07/2009}

Acabo esquecendo-me de ligar confirmando nosso encontro, fico bastante apreensiva. Ao chegar na unidade, a enfermeira que está intermediando todo o contato com Ângela não está, o que me deixa mais apreensiva ainda. Outro enfermeiro me atende. Aguardo na sala, e próximo ao horário combinado, vou ao corredor. Enfermeiro vê e liga para a paciente, que estava na sessão de fisioterapia. Este mesmo enfermeiro arruma uma sala para a entrevista e ali aguardo.

Ângela passa, vê que estou ali, mas vai para a sala de espera. Vou até ela [resistência? Esqueceu?]. Ela estava aguardando eu chamar, e novamente entra sem a irmã que a acompanhava. Nesta sala há uma mesa, usualmente como em consultórios, mas faço questão de sentar a seu lado.

Durante a entrevista, pergunto sobre sua vida antes do adoecimento, e ela diz não lembrar. Diz ainda que após o nascimento do filho, só lembra-se do que veio depois dele [Marcos da vida, da história, da memória]. Aponta necessidades da pessoa com deficiência: lazer, ocupação, fisioterapia, informação. Ângela ressalta em todo o seu discurso a importância da ação do próprio sujeito para as mudanças, para as conquistas.

Está tendo alta do serviço, e me parece que a entrevista pôde ajudá-la a fazer um fechamento deste processo, uma retrospectiva. Tento finalizar a entrevista duas vezes, ela silencia, mas retoma a fala. Ângela pontua sua surpresa por conseguir falar tanto nestes nossos encontros.

Ao finalizarmos a gravação, explico o processo de transcrição e que lhe enviarei o material para apreciação. Gosta muito deste retorno. Pede, entretanto, que eu não mude seu nome: "Afinal, não falei nada de errado...". Confirmo que deixarei seu nome, mas que algumas partes serão suprimidas para mantermos a confidencialidade e o sigilo.

Ao nos despedirmos, Ângela coloca-se à disposição para outras informações que eu precisar.

\section{Dia 10/12/2009}


Envio por carta, as entrevistas editadas a todos os sujeitos já entrevistados. Junto com este material, envio carta retomando os objetivos da pesquisa e colocando-me à disposição, bem como avisando que eles podem sugerir alterações, se acharem necessário.

\section{Dia 27/01/2010}

Após trabalho maior na transcrição, edição e análise, retomo os contatos para entrevistas com sujeitos restantes - a principio, após mudança no projeto pessoas com deficiência congênita auditiva e visual.

Faço contato com profissionais que atuam na área, mas o fato de ser def.congenita e a faixa de idade necessária (40 a 65 anos) parecem dificultar. Primeiro contato em 04/01/2010 - hoje é 27/01/10 e ainda não encontrei estes sujeitos.

Busca via internet associações de pessoas com deficiencia em SP, buscando contato. Envio cerca de quatro emails ainda sem resposta. Nestes emails, explico em linhas gerais a pesquisa, anexo o projeto (em pdf), bem como o termo de aceite da comissao de etica.

Com uma das instituições, entro em contato via telefone. Aguardo retorno ainda hoje.

Recebo hoje resposta de um email - instituição para surdos em Jundiaí indicada por colega FONO - irá verificar sujeito/possibilidade de entrevista com responsável pela reabilitação (chama minha atenção que é qualquer sujeito, não necessariamente em tratamento, mas a pesquisa vai para a coord. do setor de reab.).

Consigo retorno de uma das instituições para cegos, uma associação na verdade. Me encaminha para o centro Dorina Nowill, instituição de atendimento a cegos em saúde e educação. Entro em contato por telefone, pede a solicitação via email. Envio.

\section{Dia 01/02/2010}


Não tive resposta de mais nenhum local. Um colega médico tem contatos e enviará um email de uma pessoa que pode agenciar isso. Aguardo mais alguns dias, se nada - novas tentativas. Onde estão estas pessoas??

\section{Dia 10/02/2010}

Desde então, sem muitos contatos... Envio emails, sem muito sucesso.

Consigo entre ontem e hoje, entretanto, um contato concreto. Indicado por este colega médico mencionado anteriormente, entro em contato via email com um amigo/mantenedor de uma associação de assistência a pessoas com deficiência visual na baixada santista (LMC - Lar das Moças Cegas). Este me retorna por telefone dizendo que a associação irá indicar alguma pessoa para a entrevista e me passa o contato da associação. Entro em contato hoje (10/02) por telefone; o pedido foi para a ass.social e esta entrará em contato comigo via telefone. Aguardo!

\section{Dia 19/02/2010}

Assistente social, Mirina, do Lar das Moças cegas entra em contato comigo. Conversou com uma aluna (é este o nome que ela dá), Fátima, e esta topou participar da pesquisa. Marcamos o primeiro encontro para 22/03/2010. Marcarmos com esta distância porque irei viajar e ficar aproximadamente 20 dias fora.

\section{Dia 22/03/2010}

Vou para Santos fazer a primeira entrevista com uma pessoa com deficiência visual congênita. Não sei nada sobre ela; meu contato foi intermediado pela assistente social da instituição.

Liguei hoje pela manhã para confirmar o encontro.

Ao chegar, sou recebida pela ass.social, que vai atrás da "aluna". Aguardo e observo. Não sou apresentada formalmente à instituição, mas parece ser uma 
mistura de centro de reabilitação, convivência e escola. No andar em que estou, há adultos com deficiência visual circulando. Enquanto aguardo, na sala da coordenação, um aluno vem conversar com a coordenadora sobre seus horários.

[As cenas que vejo causam estranhamento: adultos, acima de 30 ou 40 anos, vestidos como alunos de ensino fundamental, com o típico uniforme das escolas brasileiras (calça de elanca azul e camiseta com o símbolo da prefeitura e da instituição), freqüentando o que parecem salas de aula. Que lugar ocupam estas pessoas? Que lugar ocupa esta instituição? Remeto-me a última entrevista que realizei antes desta - com Ângela - e minhas reflexões sobre a falta de espaços de convivência, trabalho, lazer. As pessoas com deficiência parecem - naquela cena - continuar ocupando o lugar da criança, protegida e tutelada em uma instituição].

Minha Fátima então chega. Somos apresentadas pela ass.social. Nesta sala, explico novamente a pesquisa e inicio a leitura do termo de consentimento. Explico que é preciso - por normas da faculdade - que haja uma testemunha, para pessoas com deficiência. Conversamos sobre o fato que isto não teria que ser necessário, caso a pessoa soubesse assinar. Quem assinará para ela é a própria ass.social, que toma a frente e lê o termo para ela.

Além da sala estar com muitos barulhos (telefone, conversas, batidas, sons ao fundo), o termo tem linguagem rebuscada. Vou explicando cada um dos pontos de maneira mais simples. Tudo acordado, vamos até uma outra sala para a realização da entrevista propriamente dita, mais calma e sem tantos barulhos e interrupções. [Percebo que a ass.social é figura de referência e confiança para a Fátima. Saber que ela leu o termo e ela assinou como testemunha parece deixála mais tranqüila para conversar comigo.]

Já nesta sala, coleto os dados pessoais da Fátima e ela também assina o termo. Para assinar, usa um instrumento bastante interessante, que chama de assinador. Uma placa de metal, com um recorte no centro - é neste espaço que ela deve assinar. Ela pede para que eu coloque o assinador no local necessário e então assina.

Começamos a conversa e ela fica cada vez mais a vontade. Conta sobre sua vida, sua doença, e vários pontos já trabalhados por mim na análise até este ponto aparecem: direitos $X$ favor, acesso, equipamentos e dispositivos de auxílio, independência. Novamente, chama minha atenção a questão da instituição - Fátima freqüenta o LMC há mais de 20 anos. Diz que lá é muito 
bom, por isso não sai; e que a fila de espera está cada vez maior. [Fico pensando na falta de outros espaços e oportunidades - Fátima não necessita de serviços específicos, mas trabalho, lazer, convivência - direitos de todos os cidadãos, em espaços para todos os cidadãos. E, esta falta de opções [será que é isso?] ou a falta de outra cultura de convivência e busca de outros equipamentos, contribui para o aumento da lista de espera, impedindo o acesso a outras pessoas com deficiência. Um paradoxo!].

Ao final da entrevista, que durou aproximadamente 50 minutos, voltamos à sala da ass.social, para que ela assine uma outra via do termo de consentimento. Aguardamos. Fátima fala mais sobre si, sobre um namorado que teve, sobre seu diabetes e sobre não se cuidar muito neste aspecto.

A ass.social chega, assina e vamos embora. É Fátima quem me indica onde fica o sanitário, pergunta se há papel, se preciso de algo. Quando se certifica que está tudo OK comigo, vai embora (terá um treino de um futebol adaptado para cegos - jogo pelo qual ela compete em campeonatos regionais, estaduais e nacionais, inclusive). [Este é o espaço dela - a pessoa com deficiência ali era eu, que precisei de auxilio para encontrar o sanitário e os outros recursos de que precisava].

Ao nos despedirmos, reafirmo nosso encontro da próxima semana, que será também em uma segunda-feira, no mesmo horário, na própria instituição, assim como hoje.

\section{Dia 29/03/2010}

Volto a Santos para o segundo encontro com Fátima. Fico preocupada se vou me atrasar, pois a chuva na estrada é muito intensa.

Chego no horário combinado, volto a procurar a ass.social, que vai buscar Fátima e a traz para a sala em que aguardo. Vamos novamente para uma outra sala, sem outras pessoas, para que possamos conversar e ter privacidade. Neste momento, acompanho-a - ela vai segurando minha mão. Na sala, não sei exatamente como orientá-la no espaço [até porque eu também não conheço aquele espaço - quem é a deficiente ali?]. Mas, conseguimos nos ajeitar, sentamos as duas à mesa, e iniciamos a gravação. 
Neste ínterim, ela conta que achou que eu não fosse fazer a entrevista hoje, somente na semana que vem. Diz que se confundiu. Pergunto se a atrapalho e se quer deixar para a próxima semana (pedindo em pensamento que ela falasse que não era necessário, pois a viagem é longa), e ela de fato diz que não há problema e seguimos fazendo a entrevista.

Muitos temas são retomados, ela conta mais sobre a infância e sobre a adolescência, sobre a vida sexual, afetiva e amorosa, sobre o estudo, o trabalho, as dificuldades financeiras (estas são, segundo ela, sua principal dificuldade). Ao longo do relato, como em outros desta pesquisa, a coragem, a força e o medo permeiam o discurso. Ela vai contando muitos episódios de enfrentamento, de coragem - romper com a família, ir morar sozinha, juntar-se ao companheiro e depois se separar, batalhar pelo dinheiro e auxílio financeiro.

Quando terminamos a gravação [e eu sempre vou avisando a ela o que estou fazendo - "Desliguei o gravador", por exemplo], ela me questiona a razão por eu estar fazendo esta entrevista. Explico novamente, falo da minha dúvida se o que é feito é o que de fato as pessoas precisam, ela parece compreender e inclusive ressalta o quanto a questão do estudo é importante para a pessoa com deficiência; comenta que na próxima entrevista falará mais sobre isso. Foi muito interessante porque ela, sem relógio, fala quando estamos mais ou menos em 50 minutos de entrevista: "Acho que esta será a última coisa que falarei por hoje, porque já estamos terminando, né?". A percepção do tempo foi muito precisa e isso me impressionou.

Acerca de seus questionamentos sobre a razão da entrevista, penso novamente na necessidade e na importância de fazer um termo de consentimento com termos mais simples e também menos longo, pois tem dificultado a compreensão das pessoas.

Ao final, nos despedimos, a levo até a porta da sala. Ela demora para se localizar (e eu também) e uma funcionária nos ajuda. Assim que ela percebe onde está, ela segue sozinha. Nos despedimos novamente, e reafirmo nosso encontro na próxima semana (dia 05 de abril) e ressalto que será a última entrevista.

No caminho de volta a São Paulo, penso que precisarei encontrar uma outra forma de dar a devolutiva com a entrevista editada para ela, pois a leitura não será possível. Penso em gravar em uma fita K7 ou CD. Irei conversar com Fátima sobre isso na próxima semana. 


\section{Dia 05/04/2010}

Vou novamente a Santos, para minha ultima entrevista com Fátima. Chove forte em Santos, há vários pontos de alagamento na estrada - fico tensa e preocupada se conseguirei chegar, se me atrasarei. Porém, consigo chegar em tempo para a entrevista. Faço todo o esquema novamente: vou até a sala da ass.social, aguardo enquanto localizam-na.

Desta vez Fátima não entra na sala em que estou esperando-a - aguarda na porta. Mirina (ass.social) indica para irmos a sala das voluntárias novamente (mesma sala do encontro anterior). Pergunto a Fátima como indico o caminho, vou apenas dando indicações: a direita, a esquerda, etc.

Na sala, nos acomodamos e percebo que ela está mais quieta. Diz estar indisposta e com sono. [Ficou em toda a entrevista falando mais baixo, mais introspectiva - ao longo da entrevista, direciono nossa conversa para um encontro mais curto diante deste movimento dela].

$\mathrm{Na}$ entrevista, retomamos a questão do estudo [onde paramos no ultimo encontro], falamos sobre a assistência em saúde e ela fala da importância da independência para as pessoas com deficiência. Foi muito interessante porque ela conta que pensou ser "louca", "ter problema mental", pois tinha dificuldade em aprender a locomoção independente - chegou a ir ao médico por sua conta para verificar esta questão. [Preconceitos e estereótipos do próprio sujeito].

Após terminarmos a gravação, pergunto como ela gostaria que eu desse a devolutiva da entrevista editada - ela escolhe que eu envie em CD, para a instituição, aos cuidados da ass.social que nos apresentou. Pergunta novamente as razões da entrevista - apesar dela própria comentar que eu já havia explicado - e então, explico novamente, e comento que a escolha dela foi uma questão aleatória e uma indicação da Mirina (ass.social). [Persecutoriedade?].

Sobre a edição da entrevista, ela pede para que eu não coloque alguns trechos mais pessoais - e me conta vários outras passagens difíceis de sua vida, muitas delas não incluídas na entrevista [Fico pensando sobre a importância do espaço de escuta - reconstrução e ressignificação da história de vida, inclusive].

Nos despedimos, agradeço-a e ela também agradece a oportunidade. Fátima ressalta que está disponível em outros momentos se eu precisar. Ressalto isso da minha parte também. 
Antes de ir embora, procuro Mirina para agradecê-la pela ajuda e disponibilidade. Ela se coloca a disposição. Aviso sobre meu combinado com Fátima sobre a entrevista editada.

\section{Dia 26/04/2010}

Após indicação de uma professora do Depto. de Fonoaudiologia da FMUSP, entro em contato com Dr.Sérgio da Clínica Reovuir. Ele me retorna a ligação, explico a pesquisa, o sujeito que estou procurando, ele se prontifica a me ajudar.

Envio dados específicos do sujeito, projeto de pesquisa e termo de aceite da CAPPESQ para ele por email.

\section{Dia 06/05/2010}

Após contatos por telefone e email, Dr.Sergio marca comigo na clínica Reouvir, próxima do Hospital das Clinicas, para que a equipe da clínica possa fazer uma indicação.

Ao chegar na recepção me apresento e fico aguardando o contato. Quem me procura é a fonoaudióloga, que pede para que eu suba com ela para sua sala, que fica no segundo andar. Ao mesmo tempo, ela chama o próximo paciente que iria atender que, junto com o acompanhante, sobem comigo. A profissional me pergunta os critérios dos sujeitos da pesquisa, eu explico; enquanto estamos na sala, o casal também está. [Fico desconfortável com a situação; parece-me que eles não estão compreendendo nada, e a profissional também não explicou, pelo menos enquanto eu estava ali]. Ela me explica que os prontuários não são informatizados, e com isso ela não consegue fazer nenhuma indicação. Sugere, então, que eu desça para a recepção novamente e busque este sujeito nos prontuários. Pergunto se não há problema em eu mexer nos prontuários, ela diz que não.

Desço e inicio esta busca, mas ainda desconfortável com a situação. Nos prontuários de atendimentos recentes, ainda não arquivados, encontro cinco sujeitos que se incluem nos critérios da minha pesquisa, neste momento (pessoa com deficiência auditiva congênita, com faixa etária entre 40 e 65 anos). 
Dr.Sérgio vem então falar comigo, e indica um paciente que tinha sido atendido no dia anterior; eu já havia selecionado-o - Sr.Rubens. Entro em contato por telefone, falo com a irmã Rosa, que é quem o acompanha em tratamentos e consultas [pela questão da deficiência auditiva, esta pessoa não tem condições de falar ao telefone, mas todo o combinado é feito com a irmã. Questão da AUTONOMIA fica presente. Reforço no telefonema se ele gostaria, se ele toparia, e ela diz que sim - mas, é uma resposta por ele, entretanto]. Parece-me que Dr.Sergio havia já adiantado com ela a possibilidade desta pesquisa e do meu contato [o que achei positivo], porque quando liguei ela já tinha alguma noção do que se tratava.

Marcamos então para a próxima semana, na clínica, no período da manhã. Fico de ligar um dia antes para confirmar.

\section{Dia 13/05/2010}

Nossa primeira entrevista está agendada para amanhã. No início da noite, entro em contato na casa, falo com o esposo de Rosa, deixo recado confirmando o encontro na clínica.

\section{Dia 14/05/2010}

Chego na clínica para a entrevista; recepcionista lembra-se de mim e do agendamento. A entrevista está marcada para as 09:00h; chego 08:30h e aguardo. Eles se atrasam; chegam 09:30h, mas estou aguardando-os. A clínica está quase vazia. Apresentou-me e subimos para uma sala no segundo andar para conversar e realizar a entrevista.

Explico inicialmente que sou aluna da Faculdade de Medicina e estou fazendo uma pesquisa. Rubens tem uma dificuldade auditiva importante, bem como dificuldade na fala. Repito algumas vezes, falo bem alto, a irmã Rosa me ajuda. Rubens não sabe ler; leio o termo de consentimento com a irmã, ele não consegue acompanhar, mesmo eu falando em voz alta. Ele confia na irmã, que explica alguns trechos para ele; ela assina a participação. Pergunto se ele 
também quer assinar, diz que sim [Fica orgulhoso disso - Reconhecimento do sujeito!].

Mostro o gravador, explico que a conversa será gravada. Rubens estranha, perguntando-me como algo tão pequeno pode gravar a voz. Inicio perguntando sobre sua história de vida, fala da infância, do cotidiano, do trabalho como pedreiro e atualmente como "faz-tudo". Tem muita dificuldade na fala, é dificílimo compreende-lo em alguns momentos. Falo bem alto, para que ele possa ouvir, mas tem dificuldade também.

Nunca usou aparelho auditivo. Veio à clínica em busca de um. Já teve um, quando adolescente, comprado pela mãe, mas nunca usou, não fez sentido. A irmã Rosa fica junto em toda a entrevista, ajuda Rubens a compreender algumas perguntas e conta aspectos específicos relacionados à sua saúde e seu percurso no sistema de saúde.

Rosa aborda a falta de vida amorosa e sexual por parte de Rubens. Percebo que ele fica com vergonha, constrangido. Mas, consigo entender que ele sente vergonha de sua deficiência, diz que mulheres não irão querê-lo.

Rubens foi muito receptivo durante toda a entrevista. Ri muito, quer falar. Parece que conseguirmos construir um vínculo entre nós. [Fico me perguntando que espaços realmente interessados de escuta ele teve, aspecto inclusive prejudicado pelas suas dificuldades de comunicação].

Marcamos nosso próximo encontro em sua casa, na próxima sexta feira. Ele mora ao lado da irmã; combinamos de nos encontrar na casa dela. Faz muitas brincadeiras comigo, perguntando como encontrarei sua rua e sua casa, se eu não conheço o lugar. Digo que vou procurar, assim como ele faz quando precisa ir para algum lugar que não conhece.

Rosa agradece e se diz preocupada se o teor da entrevista de fato me ajudará no trabalho. Afirmo que sim, mas parece não acreditar. [Fico imaginando o estereótipo, o preconceito: o que uma pessoa com deficiência auditiva, que não sabe ler, que tem dificuldade na fala, vai ajudar em um trabalho de mestrado?]. Ao ir embora, despeço-me dos funcionários da clinica, que se surpreenderam com o tom de voz que usei para conversar com Rubens, pois precisei falar muito alto. A recepcionista fala: "Ah, mas ele está sem aparelho, né?"Interpreto a fala como um juízo de valor negativo. 
Deste primeiro encontro, fico pensando muito nas dificuldades para nós ouvirmos suas necessidades, demandas, visto que ele tem a comunicação prejudicada. Que espaços teve de real escuta ativa? Parece-me que surdos somos nós, os profissionais!

\section{Dia 21/05/2010}

Havíamos agendado a entrevista para as 09:00h. Porém, houve uma emergência no local onde trabalho e precisei re-agendar. Falo novamente com Rosa pelo telefone, e marcamos para hoje mesmo, no período da tarde.

Estou a caminho quando Rosa me liga, confirmando minha presença. Diz não ser necessário desmarcar, já que estou chegando. Descubro, entretanto, que passei a entrada. Ela me explica por telefone como devo retornar e em qual rua devo entrar para chegar a sua casa.

Rosa e Rubens estão me esperando no portão; coloco o carro na garagem. A primeira coisa que Rubens me fala, é uma brincadeira em relação ao fato de eu ter me perdido. Ele é novamente muito receptivo; parecia estar ansioso em relação a minha chegada.

Fazemos a entrevista na casa de Rosa, na sala. Coloco uma cadeira próxima a Rubens e começamos. Rosa fica junto novamente, e auxilia em alguns momentos na compreensão dele ou minha. Percebo que consigo entendê-lo melhor, e também não preciso falar tão alto.

Ele conta outros aspectos de sua história de vida, Rosa explica alguns trechos específicos acerca da saúde. Muitas histórias ele me conta novamente, mas outros aspectos vão aparecendo. O marido de Rosa estava na sala ao lado; ouço-o rindo em alguns momentos - Rubens é muito espontâneo [Vínculo comigo // Espaço de real escuta interessada]. Sua fala é recheada de brincadeiras.

Seu grande desejo é voltar a trabalhar. [Questão do trabalho e o universo masculino]

Rosa comenta que ele sentiu-se a vontade comigo, que farei falta depois que a entrevista terminar. Explico que teremos mais um encontro, e que depois enviarei a sua história transcrita. Combinamos que Rosa lerá para ele. 
Despeço-me de ambos. Irão sair também para entregar galões de água. Rosa abriu um pequeno negócio, e Rubens a ajuda diariamente. Antes de ir, reafirmo nosso encontro na próxima semana, na sexta feira pela manhã. Rubens fica dando "tchau" até que eu chegue com o carro no final da rua.

\section{Dia 28/05/2010}

Vou à casa de Rosa para última entrevista, não ligo confirmando. Ao entrar em sua rua, Rubens me avista à distância e já me cumprimenta. Abre o portão da casa da irmã, para que eu entre. Conversamos desde a chegada, sobre a irmã que demorou a abrir a porta, sobre a semana, etc. - percebo que compreendo-o cada vez melhor [vínculo, tempo].

O neto de Rosa está na casa, e também vem me cumprimentar. Rosa pega uma cadeira para que eu fique próxima a Rubens; desta vez, digo que ela pode ir fazer as coisas dela que fico conversando com Rubens.

Antes de iniciarmos a gravação, ele me pergunta se já fiz a transcrição das duas outras conversas; explico que ainda não e que demorará um tempo para que eu entregue o material escrito para ele.

A entrevista seguiu por aproximadamente quarenta minutos; Rosa veio à sala poucas vezes durante este período: nos trouxe chá, e veio ajudar em uma pergunta que Rubens não compreendia (Qual é o seu sonho?). Novos assuntos emergiram nesta conversa: contou mais da infância, do tempo que morou na roça com os pais, do sonho de ganhar na loteria e de ter uma fazenda, relação com familiares, participação nas festas e encontros da família.

Ao final, a irmã Rosa veio à sala. Expliquei que entregarei o material escrito em julho; ela brinca, dizendo que Rubens colocará em uma moldura e pendurará na sala. [Penso sobre a importância da história dele, que me pareceu pouco validada para ele mesmo e para seu círculo de relações. Volto a pensar na escuta interessada, que pouco parece ter havido em sua vida].

Rosa me conta ainda sobre sua filha (que é fisioterapeuta), deixa o cartão comigo, "faz uma propaganda", vamos dizer assim. Escuto. Percebo que Rubens não está participando da conversa; procuro explicar para ele do que estamos conversando. Despeço-me, reiterando que o material escrito demorará ainda uns dois meses para ser entregue. 
Hoje é Rubens quem me acompanha até a porta, ao carro e ao portão. Despeçome novamente, e ele acena para mim até que meu carro alcance o final da rua. [Vínculo, escuta - aspectos muito fortes no processo das entrevistas com Rubens]. 
Anexo F - As histórias de vida 


\section{A história do Sr. Jair - Sem enxergar não adianta sonhar...}

Eu nasci no Estado do Piauí. Passei um pouco da minha infância aqui em São Paulo, e um pouco no norte. Cheguei em São Paulo tinha meus doze anos, e ainda tive minha juventude aqui também. Comecei a trabalhar de menor ainda, em uma firma de plástico; trabalhei até chegar os dezoito anos, até esperar o resultado do serviço militar.

Eu mudei pra cá com meus pais. Meu pai veio, então veio todo mundo. Nós viemos todos para cá, pau de arara... Já tinha dois irmãos solteiros que trabalhavam aqui, eles que providenciaram nossa vinda para cá: alugou casa, comprou as coisas para dentro da casa. Chegamos e já tinha a casa montada.

Aqui em São Paulo eu estudei, brinquei, casei, tudo foi feito aqui em São Paulo. Tive dois filhos, os dois já maiores. Sou casado há trinta e oito anos; casei em sessenta, nós estamos em dois mil e oito... Em dezembro agora faz trinta e oito anos...

Meu problema de visão apareceu de repente. Nunca usei óculos, nem pra perto. Eu lia uma bula sem usar óculos, sem nada, toda a vida. Nunca tive problema de visão, em nenhum dos olhos. Eu achava que nunca tive... De repente, a primeira vez que eu senti, eu vinha vindo do serviço e senti que sumiu a visão. Ainda bem que estava perto de um local que eu passava todo dia, uma lanchonete ali perto da Paulista, até tinha uns colegas lá; eu entrei palpando a parede, porque tinha umas cadeiras na frente. Eles viram e até brincaram que eu tava fingindo, acharam que era brincadeira. Eu disse que não, que tinha acontecido um negócio que eu não tava enxergando nada, tava vendo só o vulto.

Eles vieram comigo até o ponto de ônibus, ali na Consolação; tomei o ônibus, vim mal para casa. No dia seguinte, a visão já não tava ruim. Fui trabalhar normal à tarde, porque eu trabalhava das duas horas. Mas de noite, a mesma coisa... Eu tava trabalhando na portaria de prédio, e tinha dificuldade pra ver as placas dos carros que entravam.

No dia seguinte, fui procurar o médico, fui lá na Conselheiro Crispiniano, que me indicaram. Eu marquei um oftalmo lá. Uma moça me chamou lá na sala, e começou a examinar minha vista. Quando vi, ela saiu assim, dizendo: "Tua vista... tá com problema... tua visão". Então ela foi e trouxe acho que o mestre dela lá. E ela só falou assim: "Você já está cego de um olho... você tem problema de glaucoma". Aí que eu vim saber o que era glaucoma, e aí começou o tratamento.

Eu já não enxergava de um olho, era só vulto. O outro ainda eu conseguia. Mas foi cada vez piorando, fiz cirurgia e tudo. Acho que nem deveria ter feito a cirurgia, acho que só com colírio eu teria... porque ainda eu divugava um pouquinho ${ }^{1}$. Aí foi indo, fiz cirurgia daqui, cirurgia dali, sei que foram seis no total. Ainda enxergava cinco por cento depois da primeira cirurgia, ainda tava com cinco por cento de um olho, e outro quinze parece. Aí tô em tratamento até hoje nas Clinicas.

Isso começou em 2002 por aí, quer dizer, seis anos e pouco que eu acompanho o tratamento. Já fiz cirurgia a laser, já fiz a faca, no bisturi, porque os colírios não estavam abaixando a pressão. Porque, quando baixa fica estável, fica

\footnotetext{
${ }^{1}$ Divugar $=$ enxergar
} 
naquele patamar, mas com a pressão sempre aumentando, quer dizer, cada vez ia perdendo mais, enfraquecendo mais a visão.

E até hoje ta aí, eu tenho esperança, mas o médico... Porque antigamente eles ainda falavam que eu ia voltar a enxergar um pouco, pelo menos para largar a bengala, andar sozinho na rua. Porque teve um tempo que eu ainda andava, eu descia até ali embaixo, na praça, na rua, ia nas Clínicas sozinho. Mal, mal, mas ia sozinho. Chegava no ponto, eu pedia informação pra quando o ônibus viesse, alguém me desse um toque, aí eu conseguia. Mas agora, nada, nada. Nem para mim ir aí embaixo, não vou mais assim sozinho, eu não me arrisco mais não.

Eu já ando com medo de pisar no chão, até para andar eu tenho medo. Então estou sempre com uma pessoa ao meu lado, para me apoiar no ombro. Antes eu ainda enxergava um pouco, quando a letra tava bem escura, letra preta com a caneta bem forte, dependendo do tamanho eu divugava um pouco, mas foi indo, foi indo, agora não divugo mais não.

No começo, depois de receber essa notícia, eu andava super nervoso. Não faz muito tempo... Passei mal para acostumar, quer dizer, não tô acostumado ainda, não me conformei ainda. Tenho a esperança de um dia voltar a enxergar. Pelo menos pra mim andar, eu tenho vontade de não precisar ficar pedindo. Eu tenho um vizinho, um garotinho que anda junto comigo. Porque eu faço jogo, ele vai comigo e eu faço jogo do bicho. Eu vou jogar no bicho, às vezes vou ali no bar conversar com um colega, vou me encontrar com algum colega, conversar. Aí ele anda junto comigo.

Eu já estou meio conformado, porque o médico falou. Eu já passei em seis médicos lá nas Clínicas. Dois já me operaram lá. E esse último falou que eu não volto mais a enxergar. Antes ainda falavam uns dez por cento, vinte por cento, então me animava. Eu não via a hora de chegar o dia quando ele falava assim: "vamos fazer, tentar uma cirurgia pra baixar mais a pressão, pra ver se você vai fica melhor".

Aí num olho aqui apareceu catarata. O que não enxergava nada operou, tirou a catarata e o que não enxergava nada, melhorou. Aí passou e esse aqui sumiu. Agora esse aqui tem uma catarata, que ele disse que vai remover ela, mas não é o momento. Aí eu ainda penso quem sabe se um dia, mas ao mesmo tempo que eu penso que se tirar essa catarata desse vai melhorar um pouquinho para mim, eu tenho medo de sumir tudo. Eu ainda tenho esse trauma, não quero mais.

E essa última cirurgia que me fizeram, pelo amor de Deus, nunca vi uma barbaridade daquela. Não é criticando a medicina, mas eu acho que esse último aqui me ferrou. Porque antes não era tão doído, mas agora esse último parece que ele pegou igual ferro de soldar. E tava passando dentro do olho, assim. Ai meu Deus! E as outras operações não doeu tanto, agora essa última... Eu fiquei com medo até de eu morrer, porque nunca vi, dentro do olho, e como é que pode doer tanto? Suava frio, me doía tudo; doía a barriga, doía os pés, doía o peito, de nervoso que me deixou esta última. Então eu falei que nunca mais vou deixar mexer. Entrega a Deus, deixa do jeito que ta aí e tudo bem, porque eu não quero sentir a dor que eu senti nessa última vez.

De antes para agora, mudou muito, muita coisa. Andava mais alegre, mais contente. Em primeiro lugar não precisava de ninguém. Eu quando queria resolver as coisas, eu ia sozinho e resolvia. Gostava muito de festa, de passear, futebol e tudo isso aí sumiu da minha vida. Não tem um lugar mais, nem a 
televisão, não vejo mais nada, então. Só o meu companheiro é o radinho, dorme comigo ligado, a mulher que briga porque meu ligo o radinho e fico. É chato, não é fácil em ter que se conformar, mas eu vou fazer o quê?

Eu só rezo. Minha função é ouvir meu radinho e rezar. Rezo de manhã quando levanto, rezo de noite pedindo a Deus que eu volte a enxergar, pelo menos uns quinze por cento, vinte; cem por cento os médicos nunca falaram que vai voltar. Só ia enxergar um pouco, pelo menos pra andar sem a bengala, e tudo sem.

Antes eu andava sem a bengala, mas fez um tempo que eu andei pisando em cachorro, no ponto do ônibus. Era um sufoco danado. Agora eu arrumei essa bengala e fica batendo assim, se ele ta lá deitado, ele sai de lá, da frente. Mas não é fácil, não é fácil, não. Muda muito na vida. Tem muitas coisas aí que minha esposa que faz, precisa pedir pra ela. É chato porque você fica ocupando; se eu preciso ir no médico, eu preciso ocupar ela pra ir junto.

Eu já estou um pouco conformado, desde que dentro da minha casa, eu não sinto mais, tanta dificuldade assim. No começo, até dentro de casa eu sentia, muitas vezes dei cabeçada aí nas portas. Foi indo, foi indo, eu fui habituando. Antes até para abrir uma porta eu ficava nervoso, não achava a chave. Hoje em dia, não. Eu sinto o tamanho assim da chave, do copo; eu já sei qual é. É chato, mas ainda não perdi vaidade, nem vou perder, nem vou querer isso. Continuo sendo sorridente, a mesma coisa, gosto de brincar e tudo.

Tem um pouco de diferença no jeito que as pessoas me tratam. Eu tinha tantos colegas que conversavam comigo, mas eu já ouvi até dizer: "ah não chama ele não que ele vai dar é trabalho, é cego num...". Eu já ouvi, assim de colega. Então, existe um pouco de diferença. Porque antes se a gente saía pra ir num futebol, a gente ia no mesmo galope, né? Agora não. Se eu for sair com um deles, pra ouvir uma apresentação de um cantor de musica sertaneja que seja assim num palanque, eu já não vou na velocidade que eu ia antes. Tenho que ir devagarinho e eles precisam ir falando se tem uma subida, tem um degrau, tudo isso. Nunca senti assim ofensa, mas a atenção não é a mesma dos colegas.

Tem um cunhado meu que eu ando as vezes com ele segurado no ombro, tem hora que ele esquece que eu não enxergo, e ele anda mais rápido. A minha esposa mesmo, às vezes anda mais rápido que eu, e sou obrigado a chamar a atenção, porque quando ela corre solta a minha mão, sai do ombro e a gente fica meio assim.

Minha vida está indo... Eu gostaria de voltar a enxergar, ainda mais agora que eu estou aposentado. Eu sempre pensava assim, que quando eu aposentasse, eu ia viajar, conhecer as cidades por aí que eu nunca conheci. Sempre eu tinha essa ansiedade, e a hora que aposento vem essa deficiência?

$\mathrm{Na}$ cidade mesmo onde eu nasci, eu já voltei umas quatro vezes lá. Eu enxergando bem; agora, dessa ultima vez eu na cara dura ainda fui e fiquei três meses lá, na casa de uns parentes. Era chato; pra andar era chato, porque eu andava por intuito, mas ao mesmo tempo se eu vou ficar dentro de casa, não é pior? Aí às vezes saía pra ir nas festas, eu ficava sentado numa mesa conversando com algum colega. Mas que é chato, é chato. Sentia, porque eu não podia enxergar, andar no mato, a ir pescar, andar a cavalo, tem tudo essas coisas lá na fazenda de uns parentes. Quer dizer, a gente fica meio sem graça. Fazer o quê, né? Tem que se conformar, tem que aceitar porque senão fica bobo, porque se você não for aceitar, você vai fazer o quê? 
Dá nervoso, mas tá indo. Então, graças a Deus é só esse problema eu tenho, da visão, o resto da saúde dá pra ir empurrando. Nunca fui de ficar enfermo. Não tenho outros problemas assim. Por exemplo, é no posto, vou conferir a pressão alta, pego o remédio lá. Mas não é aquela que eu sinto mal e saio correndo. Vou lá pra pegar os remédios e passo sempre no clinico geral, que é pra fazer um check up, saber como é que está o resto das coisas. Mas nunca fiquei, assim prostado em cima de uma cama, por dor de barriga, dor de garganta, gripe, febre, essas coisas.

Problema dentário também não; só agora que minha esposa está pra me ir lá fazer a limpeza. Eu só tenho dois dentes perdidos, e foi abrindo garrafa que quebrou; nunca tive problema também com dor de dente. Só agora que começou a surgir um probleminha, mas acho que vai passar logo também, ta meio dolorido um deles.

Antes, um pouco, logo no começo ainda divugava assim, mas agora sumiu mesmo, mas eu gostaria de voltar a enxergar. Até outro dia um colega tava me perguntando porque que é que eu não aprendia o brale... braile. Mas não é pela idade, não é que eu me sinto vencido, mas eu estou com meia dois, eu não dependo mais do trabalho, porque eu sou aposentado; se eu fosse mais novo, que dependesse de ainda ir trabalhar, sair ou vender alguma coisa na rua.

Mas minha rotina agora é só dentro de casa mesmo, mais nada: comer, beber e dormir. Não saio mais. Quando tem alguma coisa na casa dos parentes, que a gente vai passear, ou tem um aniversário, eu acompanho meus filhos, minha esposa. Então só isso, mais nada.

A gente sai muito porque a família é enorme, então sempre tem muita festa. Quase todo final de semana tem um aniversário, de um sobrinho, então eu vou junto. Meu sobrinho me leva pra praia, eu fico lá, só comendo, bebendo e dormindo... E conversando; vou na beira da praia, sento numa mesa lá...

Uma penúltima vez eu ainda entrei na água com meu neto. Ele dizia: "Ô vô, pode deixar que eu fico de olho onde você está, pra você não se perder...". Mas está indo, tomo minha cervejinha de final de semana, de vez em quando, falando de futebol, encostado. Minha rotina é essa. No fim de semana eu vou na padaria ali, vou num bar do colega, sento na mesa, fico conversando com um e outro, eles fazem um churrasquinho, depois volto pra casa e cama. Fico deitado ouvindo o radinho. Só isso, minha rotina é essa.

Eu dependo de alguém pra andar daqui ali, eu não consigo mais ir sozinho. Eu tenho medo. Eu tenho uma bengalinha, mas antes com a bengalinha ainda ia sozinho, mas agora é um medo mesmo, porque essa rua aí tem muito movimento de carro. Então, não arrisco mais, to com medo mesmo de andar sozinho, não tenho mais coragem de andar, então só com meus colegas, o menino aí ou com a minha esposa. Mesmo andando junto com ela, ainda tem uns degraus, eu desço com cuidado, com receio pra subir escada ou descer os degraus. Tenho um pouco de medo, não me solto. Não é que não confio, mas não é que nem você andar sozinho.

Eu tenho uma irmã que fala que eu preciso amolecer o corpo. Mas eu digo: "você não está no meu lugar". Não dá pra você andar, ficar à vontade, andar assim como se você estivesse enxergando... você anda meio duro mesmo, com medo de bater a cara na parede ou numa porta, numa coisa. 
No dia-a-dia encontro essas dificuldades, coisinha de andar, tropeçar. Até aqui dentro de casa, por exemplo, às vezes eu ando mais rápido, eu bato na quina da mesa, as veiz se a cadeira ta, mais pra fora, não está bem encostada e eu tropeço. Essas coisas, as dificuldades. E às vezes, você fica nervoso por causa disso, essas coisinhas às vezes irritam.

Pra comer eu me viro bem, porque eu ponho a mão assim. Minha mulher reclama que derruba muito arroz, derrama comida fora do prato. A comida às vezes sai fora do prato, mas eu sinto dificuldade. Pra tomar café também sinto dificuldade: ela põe, passa manteiga no pão, põe o pão no prato, e fica assim. Tem essas dificuldades. É simples, mas perturba a gente...

No começo eu ficava no extremo de ficar nervoso. Você vê uma pessoa conversando com você, sempre naquela ansiedade de ver o rosto. Ainda bem que o pessoal é gentil. Eu encontro com moças aí na rua, senhoras de idade, que perguntam o que eu tenho, se eu enxergo alguma coisa, principalmente gente que me conheceu antes. Dizem: "Nossa... Ele enxergava tão bem, ele... era alegre, batia papo...". Eu ainda sou alegre, mas num é mais a mesma coisa.

São dificuldadezinhas que dá pra ir levando. Eu tinha vontade de voltar a enxergar, mas... Toda as vezes que o médico falava que eu vou fazer uma cirurgia, eu nem dormia aquela noite, ansioso pra chegar. Aí operava e dava uns cinco meses, seis meses, e nada... Quando passava dois meses, três meses após a cirurgia, eu falava: "Caramba! Nada, nada mesmo". Às vezes ficou foi pior.

O atendimento que eu tenho até que é bom, sabe. Não tenho a reclamar assim. Todos os médicos que eu passo, eles me atendem bem, tem uns que dá até o ombro, dá a mão pra mim seguir eles, pra ir até a sala. Então eu nunca senti assim, maus tratos. Aqui também quando eu vou no posto, tem uns que pega, me leva, puxa a cadeira pra mim sentar. Então, nunca tive assim mau atendimento, mau tratamento nunca tive. Graças a Deus! Porque tem médico que acha que, se você divuga um pouquinho, tem que ser esperto... tem uns não, que sai na frente, vê que eu estou com a Luiza [esposa]. Mas, tinha um lá que, mesmo que estando com ela; é dez vezes melhor que esse que atende agora.

Agora tem uns lá que tá louco. Esse cacete não me chama, num chega, já deu a hora. Outras vezes tem os médicos que a gente está conversando lá com ele, não ele está me escutando, aí chega outro paciente, outro estagiário e, ai meu Deus, eles começam a contar o caso do início. E eu ali com olho no aparelho. Dá vontade de falar: "Oxe, eu tô aqui... tô sentindo, tô me irritando com o... e vocês ficam aí, tititititi, os dois...". Mas eu me controlo também, sabe ainda mais que ele ta fazendo o tratamento. Eu estou fazendo tratamento com o cara, se eu for chamar atenção dele, o que vai ser? Como é que vai ser o atendimento depois disso aí? Aí então eu tolero.

Teve uma vez lá que acho que ficou conversando com outros, outro chamou ele pra ir ver um paciente de lá; acho que o cara devia ser mais experiente do que ele, aí chamam ele, eles vão lá, esquecem do cara. Aí dá vontade de eu levantar da cadeira e sair procurando o cara, chamar ele de irresponsável. Eu tô ali na cadeira. Mas acabo me conformando, porque vai fazer o que né? Sei que não é fácil não.

Eu já me conformei. Antes eu não me conformava não, eu não me conformava que eu não ia enxergar. Te juro mesmo, eu falava: "Não é possível... pra que 
tem essas porcaria de médico?". Aí eu encontrava outros pacientes que ficavam: "Eu operei o meu, eu num enxergava nada...". Mas era outra doença, agora essa glaucoma acho que é a pior que existe. Eu já vi colega meu cego que não enxergava daqui a um palmo, aí operou e voltou a enxergar. Mas o glaucoma nunca ouvi falar, quando perde, perde mesmo.

Você pode assim, quando você perceber que tem algum problema... mas eu nunca percebi, nunca percebi nada, quando eu percebi, já foi fatal, já não enxergava de um olho. Quando ele embaçou, a pressão tava parece que sessenta e quatro, e outro com cinqüenta e pouco. Quer dizer, já tava altíssima, a pressão de doze pra baixo, de quatorze pra baixo, dezesseis pra baixo. Essa que tava com sessenta e quatro já tava cego.

Foi difícil até pra acostumar. Eu não me conformava não, a ansiedade era demais. Quando eu chegava nas Clinicas eu via, chamava um, chamava outro. Tinha vez que eu chegava sete hora da manhã, que era o horário que tava marcado pra mim e saía cinco hora da tarde.

Eu consegui lá nas Clinicas no pronto socorro. Teve uma noite que começou a arder o olho e embaçar; dava aquele nervoso no olho que parece que tava pegando fogo. Aí eu fui no pronto socorro e aí chegou lá e moça falou assim: "você tem glaucoma, vou te enviar pra...". E no outro dia já encaminhou, porque era tão grave o caso.

Mas foi assim de estalo. Acho que numa semana que eu comecei a sentir, ali a visão já foi cada vez, e aí que marcou a cirurgia. A primeira cirurgia foi a laser. Aí eu naquela: o colírio de duas em duas horas, outro de uma em uma hora. Eram quatro, cinco colírios que eu usava; me irritava, porque o olho estava meio dolorido. Eu não sei se era dor mesmo ou era mais a ansiedade que eu tinha, e eu achava que tava queimando, queimando o rosto.

Eu uso esses óculos aqui, que não tem grau nem nada. Mas se eu fico sem ele, irrita. Ele dá um alívio. Quando eu saio no sol então, eu uso um mais escuro, um rayban. Parece que é uma terapia. E eu mesmo que cismei, que descobri de usar os óculos. Esses óculos aqui uma colega que me deu, porque eu começava a olhar na casa dela e vinha a claridade da luz e irrita. Aí ela me deu o rayban e eu comecei a usar. E esse óculos de sol também, não foi médico que passou também não. Eu cismei, passei num camelô e comprei um; tem um aí que meu filho comprou.

Tinha um colega meu falou assim: "Vai ver que esses óculos de camelô que ta te estragando as vista...". Mas não, não tem nada a ver. Eu nunca nem usei rayban, nunca nem usei óculos antes de aparecer esse problema. Tem hora que ta saindo água do olho, e eu ponho ele e pára, melhora.

Mas assim, quando está escuro, se eu for usar rayban fico um caipira, não tem sol nem nada. Aí eu uso outro à noite e quando estou dentro de casa. O rayban é para quando tá sol, pra sair na rua. Mas não é fácil, fazer o quê?

$\mathrm{Na}$ época que eu fiquei doente, eu tava trabalhando de porteiro. Antes, eu nunca senti nada. Eu pensava que era por causa da câmera que ficava assim de frente que forçou, uma câmera assim que filma a entrada dos apartamentos, do elevador, do pátio. Mas eu nem ficava olhando ali. 
Diz que é hereditário. Eu tenho um primo que ficou cego também. No Piauí, eu tenho uma tia também que morreu sem visão. É o tal do glaucoma também. Eu fui herdeiro dessa porcaria. E eu tenho uma irmã também que diz que está com glaucoma, só que quando ela descobriu que estavam embaçadas as vistas, ela foi e começou a usar colírio, e então a pressão não subiu. Nunca tinha ouvido falar, nem sabia disso, nunca passei em oftalmo. Se eu tivesse...

Eu nunca fui em oculista, porque se você vai em oculista, você precisa de grau de óculos, você já tem problema. Mas eu nunca tive. Sempre enxergava uma pulga, eu até brincava que enxergava tudo, uma formiga, qualquer distância assim. Eu nem imaginei de glaucoma. Só quando apareceu esse embaçamento na vista que eu fui procurar o médico, do contrário eu lá sabia que existia isso aí? Nunca tinha ouvido falar de glaucoma; ouvi falar depois que apareceu em mim.

Até artista de novela aí, fazendo papel, trabalhando como cego. No rádio eu ouço falar, mas antes eu nunca ouvi falar nisso aí. Nem essa minha tia que morreu cega e esse primo meu. Eu sabia do problema, mas não que era glaucoma.

Como é que eu ia imaginar isso aí na minha vida antes? Nunca tive problema. Quer dizer, com cinqüenta e cinco anos quando me apareceu. Aí parei de trabalhar e entrei na caixa. Eu tava desempregado quando eu entrei na caixa, porque eu saí desse serviço [porteiro]. Eu não quis nem por no pau, a firma; ele me mandou embora, e eu já tava sabendo que eu tinha glaucoma. Trabalhei poucos dias e aí ele mandou embora e eu já sentia dificuldade para arrumar emprego, então dei entrada na caixa. Eu fiquei trinta dias na caixa e já saiu a aposentadoria.

Ele me mandou embora em parte por causa da visão, porque andou entrando uns carro lá e eu não quis falar que não enxerguei. Porque ele mesmo falava para usar óculos e eu mandei fazer um óculos e tudo, mas não resolveu. Glaucoma não tem disso de resolver, porque não é vista fraca. Não adiantava, não divugava direito as placas e aí ele achou que eu tava falhando. Umas duas vezes entrou carro lá, ainda bem que não foi nem ladrão, nem isso que entrou no prédio. Eu falava assim: "Acho que é fulano...". E ele: "Como acha senhor v.?". Aí ele começou a invocar e acabou me mandando embora. Mas eu não esquentei também não, eu segui minha vida e comecei a procurar emprego em outros lugares, mas a vista ficando cada vez pior, e já que eu não arrumava serviço, dei entrada na caixa.

Mas com um mês já me aposentaram. Eu já tinha dado entrada na aposentadoria por tempo de serviço, mas o Fernando Henrique fez aquela mudança, aumentou a idade. O INSS ficou me enrolando, me enrolando, me enrolando, me enrolando. Falta isso, falta aquilo, falta documento, falta firma, procura firma, que faliu, há tanto tempo atrás, que não existe mais. E começaram a enrolar, enrolar. Aí quando surgiu esse problema: "Ah... o coitado já ta cego mesmo...". Acho que tiveram dó.

Esse negócio de aprender Braile, eu nunca pensei, porque eu digo: "Vou aprender pra quê isso aí?". Eu gostaria de voltar a enxergar, pelo menos cinco por cento. Na primeira vez que eu fui nas Clinicas, eu tinha cinco por cento de uma vista, eu ainda enxergava um pouco, uma pessoa, sabia quem era. Agora não, agora só pela voz. Eu já sei quem é a pessoa pela voz. Mas o que eu queria era divuga um pouquinho; essa é a única ansiedade que eu tenho. Agora 
estudar, aprender instrumento, assim essas coisas num sinto. Não que eu seja desanimado, me julgue vencido, mas... Outro dia me falaram assim: "Por que você não aprende uma distração, aprende a tocar um instrumento?". Meu pai foi músico, mas eu nunca me interessei. Continuo gostando de ouvir música, gosto de futebol, de esporte. Mas eu mesmo participar não.

Tem as paraolimpíadas, mas aí os que vão são novos ainda. Com sessenta e dois anos é comer, beber e dormir. E entregar a Deus. Eu até já sonhei, eu enxergando, é gostoso pra caramba, eu vendo a pessoa direitinho. Outro dia eu sonhei, a ultima vez, eu cego; não, eu quero sonhar eu enxergando. Sem enxergar não adianta sonhar.

Que é chato é chato. Quando ela [a esposa] sai, eu vou aqui no vizinho, e só aqui dentro mesmo. Mas se eu não tiver o rapazinho pra ai fazer, ou alguém fazer pra mim... Ir ali embaixo, fazer um jogo de bicho, ou ver resultado. Ela que fala pra mim. Joguei na loto fácil, ela que confere. Quando eu enxergava dez por cento, eu via um pouquinho, ainda rabiscava algum; mas agora não, agora tudo é na mão dos outros. E vai indo, vai indo...

Quando tem um passeio na casa de parente eu vou, minha sobrinha vem me buscar, quando me chama pra ir, eu vou, mas só ali mesmo dentro de casa, saio junto e sempre com uma companhia. E vai levando a vida.

Eu gostaria de voltar a enxergar, uns dez por cento, porque eu ainda ia nas clinica sozinho, não precisava de ninguém ver o número da senha. Antes eu ainda divugava um pouco. Agora, num divugo mais nada. Fui piorando. Eu pensei que ia melhorar, mas não. E eu sempre correndo atrás de um medico pra mim melhorar. E deu derrame. Eu ia conseguir enxergar, largar da bengala, pra andar sozinho na rua, mas deu esse derrame, aí ferrou tudo.

E eu tô indo aí, devagarzinho, como Deus quer e com uma ansiedade de voltar a enxergar. Às vezes eu vou conversar com uma pessoa e esbarra, fica chato pra caramba. Outro dia eu fui cumprimentar um colega, abraçar, e bati com o dedo no olho dele. Vixi, pra mim... Me dá uma raiva... Caramba, até isso você tem que ir com calma pra conversar. Outro dia fui fazer assim e bati aqui na cadeira. E um dia eu sonhei brigando e eu tava virado desse lado, e fui dar um soco assim na pessoa, que era um monstro e bati assim na parede, porque eu durmo pro lado da parede. E esfolou esse dedo com o soco que eu dei na parede, pra me defender de um monstro. É fogo.

A vida é essa. Eu tenho vontade de voltar a divugar, mas cada vez que faziam cirurgia, o médico falava que ia melhorar, e nada, nada... fazia era piorar. Eu já sofri com essas cirurgias, a laser então foram não sei quantas. Sei que no total, calculo já umas oito e nada, nada, nada. Tem uma mulher ali embaixo que tem glaucoma, de vez em quando encontro com ela lá nas Clinicas, mas ela vai sozinha, não perdeu a visão total. Eu acho que tenho agora dois por cento deste aqui e na outra, zero. Na outra eles põem umas luzes lá, pra ver se eu vejo pelo menos a luz; fecha esse não vê nada não, nada mais. É fogo, é fogo. A ansiedade é enorme pra enxergar.

Eu tanto gostava de ir em estádio, jogar bola, mas fazer o quê? Tem que se conformar. Gostava de andar bem, na moda, vestir roupa, agora. Eu só não ando pelado na rua, mas era muito vaidoso. Agora ainda sou um pouco, mas já não é mais aquela vontade que eu tinha antes pra passear, ver tudo. Eu tenho 
espírito de jovem, no modo de falar, mas já não é mais que nem era antigamente.

Tenho vontade de passear nas vilas onde eu morava, ver os colegas que eu perdi, nunca mais vi, mas porque eu não enxergo não dá pra ir lá. Chamar a mulher pra sair por aí, pra ir em bar, essas coisas, futebol, em campo de futebol, não dá. Então tem que comer, beber e dormir, mais nada...

Já me convidaram pra fazer, uma pessoa lá das Clinicas, pra fazer umas aulas. Aí marcou num lugar longe, para aprender a conviver sem enxergar, se movimentar, andar. Mas aí, pra mim ir lá e fazer essas aulas la na Pompéia. Procurar... Aí eu liguei e marcou pra daqui dois meses, pra ver se tinha vaga, pra dar início. E eu vou ter que ocupar ela [esposa], e ela tem o neto pra olhar, tem a casa. Quer saber de uma coisa, vou ficar no meu lugar mesmo e se conformar. Era difícil a vaga. Então... Aqui no próprio posto também já falaram para participar de umas atividades. Mas tenho que ficar ocupando os outros, então.

Você fica meio impaciente, no ponto do ônibus, esperando. E se pega um ônibus lotado? Eu não sinto tanta dificuldade pra voltar das Clinicas. Quando eu vou com ela, meu filho leva de manhã e deixa a gente lá e voltamos num horário que dá pra entrar e já sentar. Ainda se fosse pra pegar ônibus. Teve outra vez lá que ela [esposa] meio que falou assim: "O rapaz deficiente aí, ninguém dá o lugar...". Tem vez que eu falo: "Não, não, pode deixar que eu fico aqui, pra num fica ocupando também, pedindo, implorando lugar pra sentar...". As vezes eu brigo até com ela porque não precisa ficar pedindo, implorando lugar. Costumam dar, mas quando dá pra esperar até surgir um lugar mesmo, pode deixar a pessoa sentada que eu agüento um pouco.

Quando é pra ir lá nas Clinicas só pro médico medir, verificar a pressão e passar o colírio pra ir pegar na farmácia, porque os colírios são caros. Então compensa ir lá buscar. Então, eu tenho que manter a continuidade nas Clinicas. Já pensei em sair de lá, porque uns caras me falaram que no Hospital São Paulo tem médicos melhores. Mas [HC] é perto, tem uma condução só.

Mas porque eu já vi nego xingando os médicos: "Eu vou pôr vocês em processo, porque eu entrei aqui enxergando e tô cego... então foram vocês que me cegaram...". Eu pus aquilo na cabeça, porque eu enxergava cacete. Um pouquinho, mas eu enxergava. E minha irmã me levou nesse médico particular, pagou quatrocentos e poucos reais. Só que o médico é da mesma equipe [do $\mathrm{HC}$.

Que Deus se ouve, me perdoe se eu tiver errado, mas pra mim aquela japonesa, aquela mão de rato lá, foi que estragou. Porque a mulher tinha uma mão tão pesada, era estagiária. Ela era relaxada, vinha com aquele chinelão arrastando lá dentro, pra mim era suja, não era médica. "Num mexe os olhos", ela falava assim pra mim. Aí eu falei: "Tenho limite, assim enquanto eu não tiver sentido dor eu to quieto, mas quando começar a doer..." Ela não parava e eu dizia que tava doendo e ela continuava. "Ah, larga a mão de ser frouxo", era do jeito que ela falava e enfiando um negócio ali no meu olho. Eu digo: "Caramba, a filha da mãe que me cegou...".

No começo, eu achei que eles que me cegaram. Eu fiquei até pensando um tempo aí, o cara debaixo [da vizinhança] falou assim: "Ô, põe processo contra as 
Clínicas..." Mas aí eu vou me tratar aonde? Aí que eles vão me cegar mais... Como é que eles vão me tratar lá?

Eu acho que eles que me cegaram, eu sinto que foi isso, porque eu enxergava cacete. Eu acho, no começo, com aquelas estagiárias. Depois eu passei com o doutor Bráulio, mas eu já tava cego. Depois veio um tal de doutor Arthur, também muito bem falado, que já era professor, mas no começo quem me atendia era estagiário. Não era nem japonesa, era mestiça, cara de cachorro, com os olhos, estúpida que só ela.

Porque você vê, doutor Bráulio, doutor Gustavo, eles me fizeram laser, não usaram aquele negócio lá não. Ela tinha que enfia um bagulho no olho, pra mim não piscar. Como é que eu não ia piscar o olho? O olho é tão sensível que só você saber que vai encostando você já, até pra pôr o colírio você pisca. Mas ela achava que não, que não era nem pra gemer, não era pra sentir nada, nem dor. Eu brigava com ela pra caramba. Acho que foi que ela me cegou, acabou de me cegar.

A gente vê o tratamento do jeito que é doutor Bráulio, vejo o jeito que é outros médicos. Até a conversa do cara é outra, porque que tem médico que só de você conversar com ele você anima. Esse doutor Bráulio mesmo, quando ele falou assim: "Senhor v. nós vamos... olha seu caso está difícil, mas...". Eu até chorava de emoção quando ele falava. Mas ela já tinha estragado meu olho, tanta dor que eu senti. O doutor Bráulio aplicava o laser, que eu nem sentia. Eu saia de lá, assim com o corpo até mais leve, do que aquela ansiedade que eu ia voltar a enxergar. Mas com aquela mulher, a hora que eu saia de lá, eu já saia nervoso.

Era só o que eu ouvia, o povo lá reclamando lá dentro. Eu sentando lá esperando, só ouvia as gente reclamando de estagiário. Mas eu já enxergar nada. O povo falava assim: "Isso não é médico, é um moleque...". Médico tinha que ser pessoa de idade, tinha que demonstrar habilidade, tinha mais responsabilidade. Agora esses estagiários, a gente vai de cobaia. Quando essa médica aí me atendia, eu não via professor nenhum lá perto não.

Mas eu ficava nervoso, ia nas Clínicas, no começo putz... E a vista ficando cada vez pior. Eu chegava em casa era colírio de duas em duas horas, e eu não via melhora nenhuma. Fazia de tudo jeito, de tudo, aí eu ficava ansioso, tinha vez que dava vontade de pegar o olho e arrancar assim, dor que eu sentia. Dar cabeçada na parede. Filha da mãe, esses médicos ganham dinheiro e não resolvem nada. Eu tô mais de cobaia. Eles estão é fazendo experiência em mim. Tudo isso vinha na minha cabeça.

Eu não mudei de opinião ainda não, pra certos médicos que tem ali eu ainda acho que você vai de cobaia, eles vão te estudar. Pra mim só dois que tinha jeito de médico. Até o diálogo era diferente, a mão dele era tão suave. Eu acho que eu ia ficar bom na mão desse cara. Eu sentia que eu ia ficar, voltar a enxergar um pouco. Ele chegava com uma delicadeza e chamava o meu nome, oito horas em ponto que ele chamava.

Ainda uma vez, o estagiário me operando, aí ele falou assim: "Você não quer que eu tento doutor? Você num quer? Deixa eu tentar...". Meu Deus do céu, me vinha um arrepio no corpo, e eu batendo com os dedos e ele falava se eu estava sentindo alguma coisa ou então para eu parar com o dedo. Mas é um jeito de eu 
me comunicar comigo mesmo, ficava batendo assim, como quem que está pedindo socorro.

Agora tinha uns lá que parecia que o cara tava tentando, num tava consciente do que tava fazendo. Eu passei por cada um lá, que sem brincadeira, era pra mim pôr processo, dava vontade de tudo. Não podia ser médico aquela pessoa, cuidar do olho, uma coisa sensível; mas do jeito que aquela vinha com fome em cima: ta fazendo experiência no meu olho.

Quando ele chegar, eu vou perguntar (ele foi pros Estados Unidos): existem quantos tipos de laser? Porque esse último que o cara fez num foi laser, ele fez foi só dar alguma coisa aqui no meu olho, como que soldar. Queimando assim, eu sentindo e não parava de doer, e ele deu anestesia. E ele falou assim: "Não, não, não ta doendo, isso é a sensação que você ta sentindo...". Que sensação a bunda dele, que sensação nada, ta é queimando. Parece que tava encostando um ferro quente assim dentro do olho.

Sei lá, eu ainda falo que eles me cegaram. Eu ainda falo até hoje, eu carrego isso comigo e vai ser até a morte que eu vou carrega, vou fazer o que?

Sei que eu sofri nos primeiros lasers na mão daquela mulher lá, pra mim foi ela que me cegou. Ali eu fui cobaia, ninguém me tira isso da cabeça. Eu ali sofrendo de dor na mão dela e ela com aquela ignorância dela. Eu ali sentindo dor, esperando, e elas duas conversando sobre o passeio do dia anterior, e eu morrendo ali de dor. Eu morrendo de dor e elas com brincadeira e dando risada. Mas ali eu ficava nervoso, suava frio, dava vontade de eu voar em cima delas, porque eu sem enxergar nada, eu só ouvindo o barulho do som delas dando risada e conversando. Eu dizia: "Meu Deus do céu, onde eu tô? Aonde eu fui parar meu Deus?". Aí eu rezava, rezava, pra Santa Luzia e pra tudo que era santo.

Teve uma vez que ela pôs um colírio la no meu olho, pra dilatar, e eu fiquei lá na máquina esperando, e ardendo. Passou o efeito, aí depois de umas três horas, ela me aparece. Depois de três horas e eu lá esperando. Aí ela voltou: "Oi seu v., eu fui numa reunião, esqueci de você...". Ai meu Deus do céu, ela disse que tinha esquecido de mim. É mole? Acho que ela encontrou com outro lá e foi assistir uma palestra. E eu lá na sala, esperando. Isso aí já era quatro e meia da tarde, eu tinha chegado lá eram oito horas da manhã. Eu comi o pão que o diabo amassou ali nas Clínicas. Eu sofri ali, eu sofri mesmo. Já agora depois que eu fiquei cego não.

O hospital das Clinicas pode ser o melhor, mas tem muita deficiência, que eu sei que existe. Todos são estagiários, então que se dane a hora que você vai sair dali. Você que se dane. Se você sentir vontade de ir no banheiro, sentir vontade de comer alguma coisa, você fica ansioso pra atender, que você nem sai dali. Eu mesmo não saía, eu tava tão ansioso, que eu queria ficar bom.

O diálogo deles era curto e grosso: "O seu glaucoma chegou ao máximo...". Como se o nervo óptico morreu. Não existe nem transplante pra essa doença? Porque todo mundo hoje em dia existe transplante. Tudo que eu vejo falar é troca de fígado, troca disso, troca daquilo. Mas quando a pessoa já nasce, pode fazer transplante de olho e outro problema, outra doença que pode fazer quando perde a visão. Mas o glaucoma não dá. Que doença mais filha de mãe. Até um dia eu brinquei: "Ah, mas num pode pôr outro olho? Pegar outro olho de um morto aí e pôr no lugar desse meu, que o nervo do olho dele esteja bom?". O 
médico falou assim: "Isso aí não existe...". E eu falei: "Como não existe doutor? Não põe o coração? Não pega o coração de um e põe no lugar de outro? Porque que não pode, o olho não pode?".

Eu não me conformava quando o médico falava assim que eu não ia enxergar, que eu não ia voltar a enxergar. Então porque que eu sofro tanto assim? Com esses tratamentos, essas cirurgia que estão fazendo aí. Pra que fazer essas cirurgia? Se eu não vou voltar a enxergar. Eu ficava inconformado, ficava nervoso e ao mesmo tempo doido pra ele terminar. Eu ouvia falar, de muitas doenças que punha o tampão de noite, de manhã tira o tampão... Eu vi um velhinho lá uma vez pulando lá de alegria; eu vi só o vulto dele. Eu doido pra ver, puta merda, porque que o meu não? Pra mim tudo era doença no olho.

Na primeira vez que me operou com o bisturi, pôs o tampão e aí eu dormi lá [no hospital]. Não via a hora dele tirar o tampão e eu voltar a enxergar. E quando ele tirou de manhã, que eu não vi nada, eu disse: "Putz...". Quase que eu morro, foi mesmo que levar um susto, foi o mesmo que levar uma facada, era o mesmo que eu levar um tiro. A ansiedade era tanta.

Às vezes demora um pouquinho, um mês, vinte dias pra você ir voltando. Aí contava, eu contava os dias; passava de vinte dias, um mês, dois meses e nada... Não vai mais voltar não, não é o que o médico falou não. Ele está me enganando o fia da mãe, me enganou.

E aí aparecia um tal de derrame. Mas como é que evita esse derrame? "Ah, aparece, derrame é uma coisa que dá". O olho ficou vermelho assim, sabe, parecia uma bola de sangue. Não era fácil. Até hoje eu rezo pra Santa Luzia que eu vou enxergar. Cem por cento eu sei que jamais ia enxergar, porque o médico sempre falou, mas ao menos uns de por cento que eu tava enxergando quando ainda ia sozinho. Aí só na luta, só na luta. Colírio em cima de colírio, mais colírio, mais colírio daqui. E aí começou uns colírios também dar alergia; eu usava e o olho desse tamanho amanhecia, enchia e parecia que ia saltar fora. Tinha que parar, esperar sarar daquilo lá, pra voltar a usar outro colírio. E justamente o que era pra baixar a pressão era que dava alergia em mim.

É difícil de encarar. Eu vi muito nego ali gritando dentro das Clínicas, nego reclamando de médico, nego reclamando da assistência. No começo eu comi grama ali, porque no começo foi só estagiário, era só pra medir pressão e aplicação de laser. Eu vi dois casos de nego gritando lá, que ia processar, que eles que tinham cegado ele. Pode ser que foi outro caso, mas e daí? Mas é no olho, você num vai pensar diferente. O mesmo pensamento que eu tenho, só que o cara está desabafando ali e eu nunca desabafei, assim em voz alta. Eu ficava mais encafifado, quer dizer, eu tenho a mesma opinião do cara, só que eu assisti calado, porque pra mim aquela médica ali e aquelas aplicação de laser ali foi que me ferrou. Mas é minha palavra contra o médico, a palavra de médico.

Eu tô muito agradecido até, de você ter vindo aqui.

A vida antes do problema da visão era boa, sempre trabalhando dia a dia. Não tinha dificuldade assim pra relacionamento com amigos, com parceiros, com tudo. Eu tinha rotina normal.

Eu trabalhei já de operador de máquina, em fábrica de plástico; já trabalhei como encarregado de pessoal; já trabalhei em metalúrgica, onde faz alto-falante para carro, para som, essas coisas; já trabalhei de porteiro de condomínio, 
assim quer dizer, já tive várias funções. Já trabalhei de mecânico de manutenção, fazendo manutenção de máquina, trocando as ferramentas. Tudo em São Paulo. Eu cheguei do Norte era garoto, fiz meu primário aqui e tudo. Então comecei a trabalhar aqui em São Paulo, desde menor.

Aqui em São Paulo eu já morei na Vila Anastácio, zona oeste, no Mangalot, também zona oeste, no Parque Anhanguera, zona oeste. E aqui [bairro Raposo Tavares] já vai para vinte anos, por aí, sempre nesse apartamento. Logo que saiu, que eu fui sorteado, já vim pra ele; antes eu morava no Mangalot. Só que eu gostaria de sair um dia, assim, ir para casa térrea, porque eu acho que casa térrea fica melhor pra mim. Eu gosto de criar passarinho, essas coisas e ter quintal. Gostaria de voltar a morar em casa com quintal. Quem sabe um dia, de preferência lá no Mangalot. Eu gostava demais, lá eu morei eu acho que vinte e três anos.

Além do trabalho, eu passeava de fim de semana, eu gostava de praticar meu futebol, em campo de várzea, jogava bilhar nos bar com os colegas. Eu participava de festas, bailinho. Participava muito... Mas a cegueira tirou. Eu tinha mó vontade, antes de eu pensava assim: que quando eu aposentasse ia viajar, sabe, conhecer muitos lugares... Eu gosto de passear, aqui no interior de São Paulo eu já fui e interior de Minas, eu tenho um parente que mora, e pro norte.

Pro Estado onde eu nasci já fui umas quatro vezes, depois que eu estou em São Paulo. E depois que eu perdi a visão, só fui uma vez. Quer dizer, não foi tão legal, porque o bom era ter a visão pra deslanchar, passear naqueles matos, naquelas fazendas. Agora só dentro de casa ou quando aparece, ontem mesmo eu fui num aniversário de uma sobrinha minha aqui em Osasco, meu filho me levou até lá. E ai lá, já viu... Onde eu quero ir tem as criançadas que vão comigo, se movimentar lá dentro, porque a gente num conhece tanto que nem conhece a casa da gente, então tem um pouco mais de dificuldade que dentro de casa.

Eu tenho muitos parentes. Se for, toda semana tem festa em casa de um, aniversário de outro, sabe. Tem muito, a família é grande... Só irmãos, nós somos em nove... Primo, só de uma família, parece que tem dez, por parte de pai.Todos estão aqui em São Paulo, só um é falecido, mas tava aqui; faz uns cinco anos, mais ou menos, era mais velho. O resto ta tudo por aqui mesmo... E só esse que mora no interior, mas é pertinho, é São Paulo também: é Extremam divisa de Minas, é pertinho.

E todos nascidos lá no Norte como eu. A cidade onde eu nasci era uma cidadezinha simples: Simplício Mendes, no Estado do Piauí. Cidadezinha pequena, no interior do Piauí, fica a sete horas da capital. Eu lembro de tudo de lá, minhas brincadeiras, minha infância... da roça, do mato, vixi, eu lembro de muita... andava em animais, em cavalo, montado. Meu pai tinha uma pequena criação de boi, vaca, essas coisa.

Meus pais trabalhavam na roça. Era a vida, a vida de lá era essa. As roça eram assim, pertinho mesmo da cidade, um quilômetro, dois quilômetros da cidade. , Então era só naquela rotina, ali por ali, fiquei lá até doze anos. Até doze ano minha correria era por lá, de moleque, infância. Eu brincava de carrinho de mão, brinquedo, bola; fazia bola de todo jeito, bexiga, pano. O que tivesse na mão a gente brincava lá. A vida lá no norte é essa, assim, pras criança. Agora não, agora já bem desenvolvido, já tem muitas cidades lá que já tem cinema, essas coisas. Antes num tinha nada, não tinha nem luz. 
Não foi difícil me acostumar com São Paulo, foi gostoso. Não me acostumava só com o frio. Quando chegava na época do frio, não era fácil, porque lá... Nós chegamos aqui, por exemplo, no meio de dezembro, no verão, mas quando chegou junho, julho, setembro ainda, pra encarar esse frio não é... não foi fácil não... Vixi, mas era um frio da penha, pra acostumar... Apesar que nem de hoje em dia você não acostuma mais, a gente sofre mais, porque veio de lá, não veio agasalhado, num vem preparado.

Lá a pobreza era maior. Então, aqui já começa a trabalhar, tem mais trabalho. Mas sofre sim, quando chega sofre. Hoje ainda tem gente de hoje em dia que vem de lá e não acostuma, em São Paulo, principalmente se vier no tempo de frio. São Paulo é corrido... São Paulo é máquina, né...

Tenho primo, tem cunhado, que ainda mora lá [no Piauí], ainda tem uns parentes, pouca gente, mas tem. Mas não é pouquinho também não, tem bastante primo lá, bastante parente pro lado de lá ainda. Família é grande. Minha família é muito unida, não tem muita desavença. Somos amigos.

Eu ainda tenho um primo lá no norte e tinha uma tia que quando ela veio a falecer ela tava também sem visão. Perdeu também a visão por causa do glaucoma. Eu tenho um primo ainda, que mora lá, no Piauí, que tem dificuldade, ficou cego também, é aposentado, trabalhava no banco do Brasil e agora é aposentado. Mas ainda ta na luta, lá... é cego ainda, tem deficiência... enxerga só o vulto também.

Tem parente lá também, primo, uma outra parente nossa lá também que tem esse problema de glaucoma. São pessoas que já tem uma faixa de idade, aposentado, então fica ali, só anda com ajuda de filhos, de parente.

Faz tempo que eles têm esse problema, há mais tempo que a minha, acho. Dez anos ou mais que isso. Então eu sabia, mas só assim por cima, quando eu ainda não tinha o problema, eu já sabia que ele tinha esse problema, só que eu num sabia que era essa tal de glaucoma.

Agora tem uma irmã minha também agora em São Paulo, que descobriu que tem, só que num chegaram a perder, graças a Deus, a visão. Estão se tratando, usando colírio, enxergam ainda, bem...Graças a Deus... Não foi de repente, que nem a minha não. Elas perceberam o problema na visão, foi lá e já detectou que era glaucoma, que é pressão alta no olho.

Meus filhos já fizeram exame também, porque diz que é hereditário isso aí. Diz os médico que é hereditário. E eu acredito porque já tem essas duas irmãs, tem essa tia minha, tem esse primo, tem outros parentes. Então acredito que deva ser isso mesmo, hereditária. Então meus filhos já fizeram exame já, quando tem exame, essas campanhas que tem, eles vão detectar se tem. Se eu soubesse disso aí bem antes, se tivesse... agora tem bastante campanha. Agora dá pra ficar sabendo...

Ontem eu tive conversando com um rapaz, essa semana, aí embaixo, ele falou assim: "Ah eu também to ceguinho do olho...". Aí eu perguntei se você nunca foi... se num sabia com qual problema. Disse: "Só uso óculos, quando eu ponho óculos eu...". Você tem que saber porque que você está, se é miopia, se é isso, se é aquilo. Agora diz que a próxima vez que ele ouvir que tem campanha, inclusive no Hospital das Clínicas, aí ele falou pra mim: "Quando você, se você souber primeiro de que eu, você me dá um toque... que o dia que tive campanha 
lá eu vou...". Diz que coça, que dói a vista e nunca foi num médico. É sossego né, sossegado. Eu falei: "Quando você for olhar, é tarde...".

Eu num tenho preguiça de ir em médico, sempre eu vou, de seis em seis meses aqui no posto, fazer check-up. Tinha um médico aqui que de seis em seis meses, outro era de ano em ano, mas sempre tô fazendo as coisas. Pra saber. Mas tem gente que é sossegado, sente as coisa e num... toma um comprimidinho já...

Eu sempre fui em médico, agora oculista não. Oculista nunca fui, porque nunca tive problema, de perceber alguma coisa, alguma deficiência na vista, enfraquecimento, essas coisa. Dor no olho, nunca senti nada. Mas os médico, clínico geral, sempre, qualquer coisinha eu ia, sempre tive acompanhamento médico, na clínica geral.

Agora a visão que foi traiçoeira mesmo, esse glaucoma aí que...

Minha esposa falou que tem muita gente com esse com glaucoma [lá no Norte]. Não sei se é por causa do clima, o que que é. Eu sei que ela falou que tem bastante, bastante gente mesmo. E eles viajam pra Teresina, pra uma cidadezinha mais avançada um pouco, mas lá de vez em quando também vai médico. Vai oftalmo lá, medir pressão, que nem as campanhas que tem aqui, sabe. Então quando é um problema já grave, avançado, eles mandam pra fazer tratamento, acompanhamento na capital. Então sempre tem médico por lá, fazendo campanha, por conta do governo.

Eu fico preocupado com a minha família, principalmente meus dois filhos. O que eu perdi, como eu sinto falta da minha visão, jamais eu vou querer pra eles. Então, sinto preocupação com filho, com neto... sempre... Meus irmãos que tem por aqui, que ainda não tem problema também, eu fico preocupado de surgir esse problema.

A gente fica sim. Eu se eu puder, quando eu vê alguém, falar mal assim, que tem problema, eu já digo, já falo, já aconselho a correr pra procurar um médico, pra sabe qual é a causa, porque se descobrir antes, é melhor né... Porque se for deixar cegar, perde o nervo do olho, aí já viu...

O meu nervo ótico morreu, do olho. O nervo ótico que morre, se não circula sangue, por dentro no olho, não sei como é que é por dentro que paralisa.

Na minha família, não percebi nada assim de abandono, de desprezo. Eu acho que eles se preocupam um pouco. Eu tenho umas irmãs, quando eu vou na casa delas, elas me dá bem mais atenção do que antes. Porque antes eu num tinha problema nenhum, eu me virava em tudo, mas hoje não, mudou muito. Elas me dão bastante assistência.

Eu tenho duas irmãs mesmo, que a hora que se eu ligar, que a minha esposa não dá pra ir comigo no médico, e se meu filho também num tiver, elas vem correndo aqui pra ir junto comigo. Ou eu vou pra lá, dormi na casa de uma delas, pra ir, pra elas ir comigo no médico. Dão apoio sim, dão apoio... Se eu ligar... Eu tenho uns primo também que se eu precisar, sobrinho também.

Quando tem as vezes festa, eles falam que vem me busca, um dia antes, dois dia antes, pra ficar lá, ou pra ir passear na casa. Quando tem aniversário de 
alguém lá ou mesmo que não tenha aniversário. Se eu ficar um mês sem ir na casa de um deles, aí eles ligam pra: "Ô tio, poxa... Vou te buscar aí pra nós bater um papo...". Eles ligam sim, meus sobrinho são muito atenciosos. E antes também, mas agora eles ficam mais carinhosos, sabe. Fica mais sim, quer dizer, não é igualzinho igualzinho, mas antes eles também e agora tem mais um pouco...

Para minha família, o dia-a-dia não mudou muito não. Eles me tratam bem. Meu filho trabalha, os dois trabalham normal. Se eu precisar, eles me levam num lugar.

Nunca vi eles reclamar não, sabe... Se reclama é pra eles mesmo. Assim: "Ah, não posso ir agora, ou estou perdendo tempo, tá me atrapalhando...". Nunca percebi assim. E também eu num sou, eu num fico cobrando. Eu sei que eles tem a vida deles e não fico querendo: "Ô, vamo ali, vamo ali, me leva ali...". Não fico perturbando, então eu não sinto assim, apoio eles sempre dão.

Deixa passar, deixa ele voltar, que ele já volta em janeiro... Aí eu vou conversar com ele e vou ver, deixa ele me examinar, pra ver. Às vezes ele traz alguma idéia nova de lá, os paises lá talvez sejam mais avançados, tenha mais conhecimento de alguma coisa de lá. Então vamos ver, em janeiro ou fevereiro ele ta aí.

Eu vou nas consultas com a minha esposa. Já fui de ônibus, meu filho leva. Mas a maioria das vezes meu filho me leva de manhã. E fácil não é não, a condução é difícil pra quem enxerga, pra quem num enxerga... Porque quando a gente entra no ônibus, logo alguém quer da o lugar, pessoa que tem deficiência, né... E não me incomodo não. É bom né, que me dê o lugar, mas se for questão de esperar vinte minuto, meia hora, em pé até surgir um lugar... Eu mesmo falo pra ela [referindo-se à esposa] pra num cobrar o lugar. Já vêem eu com a bengalinha, sabe... Não sinto essa dificuldade, sempre quando eu venho de ônibus, não está lotado, tem um lugarzinho lá, por causa do horário que eu venho.

Na calçada, com guia dá pra andar. Meio temeroso, mas dá né... Sozinho eu não ando nas calçada, ando sempre com alguém do meu lado. Tem um moleque aí que vai comigo e também não fico muito na rua não. Às vezes saio de manhã, vou ali fazer o meu joguinho, eu vou junto com ele quando ele chega da escola, aí já volto... fico por aqui, aí fora. Saio aí pra garagem, vou na casa de vizinho, de colega meu... Aqui dentro eu saio... Vou até o portão, fico conversando com alguém aí, algum colega que aparece lá, tão aposentado aí, dos outros blocos sempre tão por aí. Não fico só aqui dentro de casa, plantado, não... Saio aí fora, mas não na rua, na rua eu só vou quando vou com ele até la embaixo, e volto. Faço meu jogo, volto. Eu sinto falta, era bom é ter a visão, pra ir todo dia.

A gente quando é aposentado, a pessoa quer andar... Porque você num é aposentado, não, você sai pra trabalhar, é uma ocupação. Agora estando aposentado, você quer conversar, quer sair aí fora, porque só conversar dentro de casa parece que não é o suficiente, você quer alguma novidade que tem lá na rua, quer saber alguma novidade de alguém da rua...

Estava trabalhando quando eu senti esse problema, eu percebi que o cara, ele achava que eu tava falhando. Aí me mandou embora. Me mandou embora, pagou meus direitos e tudo. Aí eu comecei procura serviço, num achava. Eu não estava fazendo tratamento, mas já tinha percebido que tinha alguma coisa 
estranha no olho. Eu já tinha ido no médico; a primeira vez no médico que foi descoberto a glaucoma, mas não tinha feito nenhuma cirurgia. Aí, mandou embora, até pra por um parente dele lá... Você sabe como é que essas coisas: tinha um parente dele desempregado e que tinha experiência também de portaria.

Então eu não fui contra, me mandou embora, tudo bem, pagou meus direitos. Aí comecei a procura serviço, e tudo sabe... Mas vi que eu já tava com dificuldade. Eu estava procurando serviço de porteiro, no ramo de porteiro. Comecei procurar, que já era mais... Se fosse um servicinho de mecânica, nessas coisas, em fábrica seria mais difícil ainda. Principalmente longe. Porteiro já é uma coisa que você fica ali sentado, e tal, não tem tanto...Mas eu percebi que tava demorando, daí que que eu fiz? Entrei na caixa... Dei entrada na caixa, no INSS, encostar no INSS... Por causa da visão...

Eu ainda enxergava um pouco, mas com dificuldade. Eu dei entrada na caixa, e começou a fazer o tratamento. Foi piorando, foi piorando, foi piorando... Aí eu acho que eu fiquei trinta dias na caixa, só recebi um pagamento, digamos... Só um benefício da caixa e aí já saiu minha aposentadoria.

A aposentadoria foi por invalidez [fala da esposa]. Mas como eu já tinha... porque foi o que o médico me falou assim: "Ah, você já tem tempo de aposentar...", falou o perito do INSSS. "Vou pedir sua aposentadoria".

Aí já veio a aposentadoria, não vou mais correr atrás de serviço, sem chance mesmo de correr. Quer dizer, já num tinha serviço, já estava difícil os empregos e eu com esse problema... Como saiu [a aposentadoria], nem esquentei mais a cabeça não. Aí já comecei a depender da aposentadoria, a viver da aposentadoria. Foi até agora, fazendo tratamento.

Coisa que eu precisava era voltar a enxergar. O meu tratamento está bom, mas o que eu gostaria assim, é de ser atendido o mais rápido possível, porque ali quando você entra lá dá um... Quanto menos tempo você ficar lá dentro, pra mim era melhor... Chegar, por exemplo: deu oito horas, ele marcou oito horas, chama meu nome aí, já vai lá dentro, já mede a pressão, está com xis, xis, xis, volta tal dia - eu me sinto melhor. Quando fica lá, que chama lá pra dentro, demora... parece que você vai... um estado de nervo fica maior... você vê crianças às vezes chorando, de um jeito, reclamando de... Então, quanto menos tempo ficar lá dentro, eu acho gostoso quando eu chego lá que eles chama meu nome logo, naquele horário e que ele atende, já chama lá pra dentro pra medir a pressão, já... Parece que eu volto mais satisfeito de casa...

Nesses hospitais, você já vai apreensivo, você já dorme pensando: ô amanhã eu tenho que ir no médico... Você vai com tudo aquilo... Aí quando chega lá que demora pra atender, você vai ficando mais chateado, nervoso, invocado, então... Não de agredir os outros, mas você não fica normal, relaxado. Você fica sempre tenso...

Ah, quando ele atende rápido, que chega no ponto de ônibus também, vem o ônibus logo, não demora muito. Tudo essas coisas ajuda muito no estado. Você fica ali tomando sol, o ônibus não vem e quando vem, vem lotado... Tudo essas coisas tira você... Agora quando você é atendido rápido, você chega no ponto do ônibus, logo tem o ônibus, você entra... Tem lugar pra sentar... Tudo isso aí é um alivio, alivio de espírito... Pra pessoa tudo isso aí ajuda muito. 
Eu acredito que a pessoa que tem desses problemas de visão, não pode ficar tomando chá de cadeira nesses lugares. Tem que atender, fazer... Quando o médico te chama, não tirar a atenção de você, num sair pra ir pra outro lugar... Atendeu, mediu tua pressão e tudo, é gostoso assim. Eu acho gostoso assim, eu fico aliviado quando eu vou no médico assim. Agora quando eu fico tomando chá de cadeira eu... ts, ts, ts... Dá nervoso.

Já me ofereceram outros tipos de tratamento, pra eu me adaptar. As Clínicas mesmo, diz que ia fazer isso aí, só que depois passou em dois lugares, aí mandou voltar a ligar e era longe. Eu pra num ocupar os outros, eu acho que num ia ser útil... Porque minha esposa tem as coisas dela em casa, aí eu ia ter que ocupar meu filho, pra me acompanhar, ou ela... Parece que era toda semana. Uma era lá em Santana, outra era... tudo longe e um horário chato, à tarde. Aí ficou de voltar a ligar pra ver quando ia ter [vaga] e aí eu não corri atrás não. Como se diz, pra aprender a conviver, não... Eu acho que não preciso disso, tô conformado. Se eu precisasse ainda trabalhar, ou se eu fosse depender de fazer, de alguma outra coisa pra sobreviver, aí eu podia até correr atrás...

Se eu tivesse que nem no começo, um pouco, que eu ia sozinho, ainda dava pra mim tomar o ônibus aí, dava pra mim... Eu conhecia o médico, divugava a imagem da fisionomia do médico... Se fosse assim, eu mesmo ia arriscar fazer isso aí. Mas não, agora pra mim ir, preciso depender dos outros pra ir, então não me interessei mais nisso aí...

Não é que eu seja um cara desanimado, não... Mas é pra não ocupar os outros. Eu sei que tudo é válido, mas válido desde que você não vá ocupar o tempo de outra pessoa... E pra tudo em São Paulo... Meus filho trabalham, ela trabalha aqui, toma conta do neto. Eu vejo aí a correria dela. Se isso aí fosse resolver, e se eu tivesse carente de... Dá pra mim viver do jeito que... Não vai ser a salvação, dá pra mim viver conformado dentro de casa. Se eu tivesse rejeitado dentro de casa, ninguém me desse atenção. Estou normal, tenho respeito dela, dos filhos, dos parentes. Então eu acho que isso aí não vai ser útil pra mim ir. Eu acho que minha convivência com eles está boa.

O que eu queria era enxergar um pouco, pra mim andar só.

Se eu conseguisse enxergar um pouco, eu ia passear. Porque eu estou aposentado, num tenho uma idade pra trabalhar em firma. Poderia ser até que arrumasse um bico pra fazer, pra passar o tempo. Sair de casa, ficar quatro horas fora, pra tomar um ônibus, ir aí... Pra lutar, pra ter... A minha está boa...

Eu conversando com outras pessoas aí na rua, elas falam: "Nossa... nem parece que você tem problema de... Você conversa assim, normal... Não vê você lamentando...". Porque eu não procuro carrega, quando eu estou conversando com alguém, assim fora... não procuro humilhar a pessoa ou ficar nervoso. Converso. Então, eles falam: "Tem gente que resmunga mais da vida e não tem problema de visão, não tem nada... e reclama mais que você...". Tem gente que reclama demais, eu não. E sempre fui calmo assim.

Não é que eu perdi a alegria, nunca fui assim irritado. Fui sempre amigo de todo mundo, nunca fui de andar brigando sabe. Nunca fui um cara isolado de brincadeira, isolado de amizade, isolado de festas. No tempo de solteiro, todos os domingos tinha aqueles bailes na Lapa. Eu ia, eu tinha meus colegas, minha turma pra ir junto. 
Fui sempre liberto assim. Porque tem rapaz ai que nunca dançou, nunca foi em baile, não gosta, é só trabalhar. Toda vida, meu fim de semana é meu fim de semana. E vai levando, vai levando...

O que eu quero, eu quero, eu quero e tenho fé que ainda vou enxergar. Não é pra correr, ir atrás de glória, nem isso nem aquilo. É pra não precisar...

Aqui no bairro tem outras pessoas que tem o mesmo problema que eu. Tem uma senhora lá embaixo, tem um outro que está sempre participando da igreja. Ele tem deficiência, tem glaucoma também. Mas eles, ele ainda anda na rua, sozinho. Mas, porque ele não enxerga de um olho, o outro ele ainda divuga um pouco... dá pra ele andar sozinho.

Ele sempre conversa comigo lá embaixo, fala: "Pô, você precisa logo enxergar um pouquinho que nem eu enxergo, pra nóis cai na gandaia aí...". [Ele responde] Ah, pode deixar que eu estou fazendo o tratamento, uma hora eu vou voltar a enxergar um pouquinho e aí nós vamos dar um rolê. É isso que eu penso, te juro que eu penso...

Eu tenho um parente que mora no interiro, mas pra mim ir, ela [a esposa] tem que estar de férias. Ela tem que ter a folga pra ela ir, ou meu filho, pra levar, porque os dois trabalham. E se eu enxergo um pouco, eu ia sozinho, não precisava ocupar.

Tem que ter a fé, enxergar um pouco. Eu tiro força de Deus, tiro força Dele. Eu sou religioso, eu sempre fui. Sempre freqüentei a igreja, eu rezo nem que for diante de uma imagem. Tenho uma imagem de Santa Luzia, tenho imagem de Nossa Senhora Aparecida. Eu rezo à noite, com ela na minha mão. É, e eu tenho fé. Não sou um ateu. Já freqüentei até outras igrejas evangélicas, se me levar, eu fui... Nunca digo que não vou.

A minha igreja eu freqüento, mas não todos os domingos, todo os domingos, todo os domingos. Mas cada dois domingos, cada três... Um domingo sim outro não... Ontem mesmo teve a procissão de Nossa Senhora Aparecida... É que foi às seis horas, e já foi à noite, e à noite eu já sô negação pra andar... Eu sou temeroso de andar a noite, mas, já acompanhei procissão aqui, quando sai aí da praça.

A força que eu tenho é Nele. Eu peço toda noite, agradeço todo dia. No dia seguinte eu agradeço pelo dia de hoje. Não sou contra também as outras religiões, não... Cada um é cada um, tem fé num Deus, que só existe um Deus né... Não existem vários deuses não... Eu sempre eu gostei, mesmo no tempo de solteiro, no tempo de garoto, sempre gostei de ir na missa, assistir a missa aos domingo. Minha mãe sempre foi também de dentro da igreja... Me sinto bem quando vou, parece que sai mais leve de lá.

Tanta gente já ficou, diz que já ficou bom... Então eu tenho fé que um dia eu vou voltar a enxergar. Porque diz que tem uma passagem na bíblia que diz que um dia o cego vai enxergar, o aleijado vai andar... Eu estou esperando, tomara que chegue logo, enquanto eu tiver vivo.E que num demore muito não...

As pessoas com deficiência precisam de tratamento assim, de condução. Pra andar assim, por exemplo, dentro de um supermercado, precisa de muita ajuda, muita compreensão, às vezes cooperação. Até na rua precisa muito; às vezes você vai passando, tem uma pessoa sentada, não tira o pé, às vezes a calçada 
está...Eu aqui não, eu já não tenho essa dificuldade, mas seria bom que todo ser humano entendesse.

Eu desço as vezes com colega e ele fala assim: "Dá licença...". E tem gente que fica meio assim. Eu falo: "Não G... dá pra sair fora da calçada? Sai um pouco, depois torna a voltar...". Porque tem gente que vê você vindo com a bengala, vindo com acompanhante, as vezes não sai da frente, não dá licença. É desligado né... Não digo que seja nem maldade, as vezes é pessoa desligada: Falo: "Não... a gente está com guia, o guia tira ele fora um pouco, só sobe na outra...".

Eu acho seria muito útil pro pessoal assistência dentro do ônibus, dentro de uma condução. Isso aí é muito necessário pro atendimento. A compreensão é muito boa, isso aí é uma coisa muito básica, faz até ele [o deficiente] se sentir mais à vontade dentro do ônibus, dentro de um banco... Mesmo se vai com uma companhia, todo deficiente visual, se o atendimento dele é mais rápido, mais atencioso, ele se sente bem... Em qualquer lugar que você vai. Eu mesmo quando eu vou fazer meu jogo, eu prefiro fazer logo. Às vezes, chega e pode ter um assalto, ali uma coisa; então quanto mais, menos tempo você ficar lá dentro...

A assistência é muito bom, isso é muito necessário pro deficiente. Ele se sente mais seguro, se sente mais à vontade, aí pra andar na rua. Aqui mesmo quando eu passo no ponto de ônibus, tem os cobradores, que sempre eles fica conversando ali: "Dá licença que nosso amigo vai passar...". Então eu acho que tudo é importante... Todo mundo deveria ter essa ajuda, essa compreensão por parte de... o respeito. Todo, todo deficiente deveria ter, é gostoso pra ele, ele vai se sentir assim, até mais aliviado. Não passa nervoso, porque tem gente que não... Agora eu não, nessa parte eu tenho tido sorte. Às vezes eu vou ao supermercado, com esse meu coleguinha mesmo, ou eu compro, a mulher pede pra comprar alguma coisa, eu estou junto com ele... Eu chego lá e peço, eles me atende assim, na frente de outro ali... Sabe que é pouca coisa, que eu num vou trazer pacote, essas coisas, então me atendem com mais rapidez... Então isso é muito bom, pro deficiente visual é bom, uma ajuda boa.

$\mathrm{Na}$ parte da saúde, dos tratamentos, seria necessário a pessoa ser bem atendida, porque desde que ele é bem atendido, ele fica mais relaxado. Não fica muito tenso.

É muito bom pra qualquer tipo de deficiência, se ele está tratando da saúde, se ele é atendido com mais respeito, e com mais atenção. A pessoa se sente mais a vontade, mais compreendido.

Eu tenho tido sorte assim nessa parte, quando eu entro no ônibus a pessoa já: "Ô, ô... vem aqui, vem aqui... tem lugar aqui, tem ali...". Então tudo isso aí a gente se sente mais confortável...

Conheço várias pessoas que não receberam essa atenção. Tem uma menina, uma colega minha, ela não tem os braços; tem só um, o outro ela só tem um toquinho. E às vezes ela foi pegar um dinheiro para pagar o ônibus, caiu o cartão, aí ela disse que como o ônibus estava lotado, ficou chato para pegar. Ela abaixar, pra pegar, ela só usava uma mão, ao tirar a carteira do bolso, caiu no chão.Então, o motorista, o cobrador deveria pegar pra ela. Porque caiu assim, embaixo... Ela falou pra mim que um rapaz falou: "Ô, pega o cartão da menina, que caiu aí embaixo, está perto de você, do seu pé, pó...". Quer dizer, então, 
essas coisas é muito chato, né... pro atendimento, porque ia demorar, né, o ônibus num tava cheio? Tudo essas coisas eu acho que é falta de atenção.

Mas já vi reclamação... Tem outro colega meu também que ele é, que pra subir no ônibus usa muleta. Ele tem dificuldade, às vezes tem motorista que vai lá, tirar ele da cadeira, dá a mão, tem motorista que faz isso. Mas tem outros que não, se puder, quer que o cara entra rápido e tchum.

Às vezes vira a cara pro lado, isso aí já aconteceu comigo nas Clínicas. De eu dar o sinal [pro ônibus] e o cara... Eu acho que o cara me conhece, sabe que eu entro pela frente, não paga passagem, eles não gostam muito de pegar as pessoas deficientes, as pessoas de idade. Acho que eles pensam que não poderá acontecer isso um dia com ele, ficar velho ou sofrer um acidente, ou da família deles... Maldade, eu acho que maldade... Quando é um velhinho no ponto do ônibus, eles odeiam parar pra pessoas de idade, tem muito motorista que odeia, passa direto, vira pro lado assim e faz, finge que não está vendo. Mas comigo foi uma vez só...

Tem um colega meu que ele toma ônibus aí, de cadeira de roda... E agora ele arrumou um emprego, em uns projetos que o governo tem aí pra pessoas, de firma que emprega deficiente. Está na cadeira de rodas, mas ele é... sei lá... um bom profissional... No começo, estava ruim pra ele, porque ele ia todo dia, e não pegava sempre o mesmo motorista. Agora não, agora tem uma perua que vem buscar, acho que alugaram ou é da própria firma, não sei como é que é. Eles vem buscar um pessoal aqui, que tem esse problema... Acho que é da prefeitura, é conveniado, acho que a firma é conveniada da prefeitura.

Eu tenho um sobrinho meu que é deficiente da mão, e a prefeitura sempre assim, fornece uma vantagem pra firma pegar essas pessoas com deficiência. Não sei se é sobre imposto, ou qualquer coisa, tem um abatimento, uma vantagem pras firmas.

E é uma coisa boa, se eu tivesse uma pequena porcentagem [da visão], eu ia arrumar uma ocupaçãozinha aí. Sinto falta, pelo menos de sair de casa. Quer dizer, se eu tivesse condições eu acharia bom [o trabalho], era uma distração. Porque tem muitos, que o defeito visual que dá ainda enxerga um pouco. Mas a minha já não dá mais, a gente sente falta.

E não dá, não tem jeito não... Se eu tivesse um pouco de porcentagem, mas não tendo é fogo. Você enxergando um pouco, você ainda sente um pouco de coragem, mas sem enxergar nada você tem medo de errar.

Porque será que aparece a deficiência na vida das pessoas? Não deveria existir... nem sei da onde que vem isso aí... Será que é castigo, será que o cara é merecedor? Acidente? Eu trabalhei numa firma de metalúrgica, e todos eles faltam um pedaço de dedo... Então vai dizer que todos aqueles merecem? Sei lá eu, por isso num dá pra você explicar... É merecedor a pessoa? Sei lá, é castigo? Acho que é coisa que num tem explicação não... É coisas da vida que nem fala...

Quer dizer, acho que não tem... Quando as prensas são perigosas, acho que qualquer um está sujeito a... Num tem isso de ser merecedor não... Já vem mesmo do acidente de trabalho... Às vezes quebra a mola, não é desatenção da pessoa. Mais atenção do que eu tinha nas máquinas, e aquelas máquinas eram perigosas... Mas teve um dia que ela ia me catando, ia sobrando pra mim. Mas, por um triz... A mola quebrou, quando senti, bateu assim, mas a rapidez da 
minha mão foi que deu pra sair. Mas eu senti o bafo, ia pegar em cheio a minha mão.

Teve uma vez aqui nessa mão, foi plástico quente... Eu fui ligar a máquina, pra sair o plástico...Porque o plástico é o seguinte: ali dentro do canhão o plástico vai até aquela caloria, mas tem a resistência, a chave que no automático liga e desliga, e vai até aquela temperatura. Mas, acho que tinha uma resistência lá que tava direta, só que eu num vi no painel, e então o plástico saiu normal o pequeno, aí depois uma camada que tava no meio, já tava só o liquido e soltou. Foi só num pulo assim, eu protegi assim, só que ficou na minha mão o plástico colado. Fiquei uns três meses no seguro depois, pra fazer a fisioterapia e voltar ao normal, porque não mexia a mão.

Eu não tinha movimento nenhum. Eu fazia as coisas só com a outra mão. Fiquei afastado. Justo naquele dia faltou um funcionário, e eu era encarregado daquele dia... Não era pra mim estar lá. Não era pra mim fazer aquele serviço, mas como ele faltou, chegou atrasado, eu fui dar o inicio e pôr a máquina pra trabalhar. Quer dizer, era pra pegar ele, pegou eu... Quando tem que ser... Isso foi em oitenta e três, faz tempo...

Eu me tratei lá no Ipiranga, João Vinte e Três parece. Perto da firma onde eu trabalhava. Eu até briguei com a enfermeira lá do hospital, porque ela me enfaixou toda a mão, cheguei em casa parecendo uma múmia. Um colega meu que veio me trazer em casa.

Aí no dia seguinte, eu fui lá e desci o pau, porque tinha dado uns pingos, mas não era motivo pra enfaixar as duas. Tive que dar um jeito de pôr o dinheiro da condução aqui assim [no bolso], pra ir no hospital. Foi dura pra enfermeira deixar eu sem... Elas falaram que eu ia ser responsável se acontecesse qualquer coisa. Eu me responsabilizo, não estou sentindo nada e essa mão aqui não teve nada. Essa outra aqui sim, mas essa aqui só respingou e vocês me enfaixaram as duas mãos. Mas é fogo, acidente é...

Eu ainda sinto, a mão ficou sensível... Mas graças a Deus não foi tão grave assim. Tem gente que - queimadura de terceiro grau principalmente, com plástico - não recupera não. Fica a cicatriz pro resto da vida. Mas fora isso, eu nunca tive acidentes assim, foi só esse da mão. E esse problema da visão que veio de repente... É que nem um acidente, porque nunca tive problema anterior. Então foi um acidente, né... Mesma coisa que um acidente.

As pessoas com deficiência que eu conheço ainda tem muito trauma. A deficiência traz um trauma pra pessoa. Eu sinto isso sim, mas traz mesmo pó. Só a ansiedade de eu querer, de eu estar conversando com uma pessoa e de querer enxergar, aquilo já é um trauma que sempre a pessoa vai carregar. Aquela ansiedade de ver a pessoa, entende. Porque é sempre um trauma, é a mesma coisa quem tem acidente na mão, e ao pegar em algum objeto não pega, tem sacrifício pra pegar nas coisas, porque a mão falta dois, três dedo. Tem diferença. Até pra escrever, às vezes vai aprender a escrever com a esquerda. Tudo isso a pessoa tem trauma, dificuldade.

Eu tenho uma colega minha ali, que ela sofreu acidente na mão. Então ela aprendeu a escrever com a esquerda, sem ser canhota. Tem um colega meu também que perdeu a mão, a parte dos dedos na prensa, e ele escreve com um toquinho só; põe a canetinha no meio do dedinho, segura no meio dos dedos e consegue escrever. Mas, você vê como é que é, porque ele tem boa visão ele 
consegue escrever. Ele acha que a letra dele ficou muito feia, porque ele tinha boa caligrafia e não voltou a escrever como ele escrevia antes. Ele teve que se virar pra aprender. Então qualquer deficiência traz um pouco de trauma pra pessoa.

Os médicos e as pessoas que trabalham com as pessoas que tem deficiência podem ajudar pra superar o trauma, em muitas coisas. Até os tratamentos em si. E a conversa, o diálogo, ajuda muito. Aquilo que eu te falei, quando um médico conversa com você, te atende bem... Todo tratamento que dá com as pessoas, com a pessoa conversando com você, é muito útil. $E$ também é muito útil a assistência que dá, você se sente, se o cara atende logo... Tudo isso ajuda a superar o trauma... Ajuda muito, muito, muito mesmo. Então toda essa atenção das pessoas que dá ao deficiente é muito importante, Inclusive os médicos.

Quando demora pra dá assistência a gente fica até com suor assim no corpo, dá aquele nervosismo na gente. "Pô não vai me atender?". Eu vi uma vez um médico falou assim: "Não, deixa eu atender esse aqui, que o caso dele é mais... [grave]". Foi um senhor que entrou com dor. Então, aquele cara que entro com dor, se ele é atendido mais rápido, pra ele sair de lá, pôs um colírio logo para ele sarar, ele não vai se sentir mais contente?

E, por exemplo, que nem a minha esposa... Acho que quanto mais rápido ela for lá, porque ela que num tem o problema, ela tem que fazer uma coisa dentro de casa e se o médico me atende rápido lá, ela também vai achar mais gostoso e voltar mais rápido. É uma ajuda muito importante do médico, porque aí, invés dela gastar, digamos duas horas lá dentro do hospital pra me atender. É bom pra quem acompanha.

E toda pessoa que está ali no hospital pensa a mesma coisa. Na sala de espera, você vê gente reclamando: "Ô, não chama meu nome... Eu estou aqui desde seis horas e não chama meu nome... Será que o médico vem?". Fica naquela ansiedade.

Tem gente que levanta, vai lá no guichê pra se informar se o médico veio. Minha esposa mesmo já fez isso aí, de ir lá perguntar. E eles informam sim. Tem uns que às vezes informam sim, que já viu ele por ali, mas não sabe se ele está por ali. Isso é muito bom, tanto pro acompanhante como pro paciente.

Eu fico contente quando eu vou lá e me atende logo, fico bem aliviado. Parece que o corpo ta... quando vai rápido e volta rápido, atende logo no hospital, você não fica... Agora se você ta ali aflito, que o médico não te atende, ainda tem uma pessoa, um outro paciente lá chorando: fica mais nervoso. Dá mais nervosismo em você, de ver uma pessoa chorando, uma criança principalmente. Se o médico tem que pôr um colírio no olho dela, ou isso, aquilo... e ardendo... Você sente aquela aflição, nem que não queira, mas sente sim. Por isso que é bom o tratamento quanto mais rápido melhor, a atenção que te dá, e o atendimento.

E porque se você fica, quanto mais tempo está ali, às vezes você fica ouvindo reclamação de um ali, sempre tem reclamação. Tem gente que fica ali, que a gente vê falar: "Tô doido pra ir tomar café, mas fico com medo do médico me chamar...". Tem medo de descer às vezes para tomar um café. Num é que perde a vez, mas às vezes você vai demorar mais tempo, se te chamam. Vai pro fim da fila da chamada. As pessoas agüentam ali... se precisa fazer uma 
necessidade, ou qualquer coisa... Tem gente segura, segura, segura, com medo de ser chamado... Não deixa a pessoa apreensiva? Deixa tão apreensivo que às vezes passa vontade de ir, você fala: "Não...". Principalmente se você acha que ele vai te chamar logo.

É melhor esperar, pra depois quando sair. Mas, parece que quando ele te chama assim, até a vontade some um pouco... "Graças a Deus que me chamaram...". Aí você levanta, vai lá pra ser atendido, parece que até passa. Sei lá, pode ser até o psicológico da pessoa. Dá nervoso...

E o movimento de gente? Tem dia que você não... pra você dar um passo lá dentro é... Vamos supor que o cara esteja fazendo tratamento há cinco anos lá, então ele já diz: "Ih, todas as vezes que eu venho aqui é desse jeito...". Nem que ele vá de mês em mês, todas as vezes que ele vai está do mesmo jeito. Então não é fácil, não é fácil mesmo.

Quando eu ia no começo, passar ali no PS... Meu Deus! O que eu via de gente ali na maca, me dava até nervoso. Ficavam pra fora, porque não tinha vaga nos quartos. Mas aquilo pra mim era o mesmo que me dar uma dor assim... Quando eu via gente gemendo nos corredores ali, numa maca. Eu sentia junto. Me dava vontade logo de me atender pra mim sair dali, porque eu não sou muito de ficar dentro de hospital, de sala junto de muita gente doente. Não gosto de...

Eu tive um irmão que ficou no hospital; ele ficou internado muito tempo na Santa Casa. Quando eu ia visitar, quanto mais rápido eu saísse de lá de dentro era melhor. Eu não gostava de ficar ali conversando... Meu pai também quando teve internado - fez cirurgia, negócio de desentupimento de veia, artéria, no coração - quando eu ia lá, eu ia pra flor da pele e era um alívio quando eu saía logo, ficava naquela ansiedade de sair logo. Não gostava de ficar...

Não sou muito de ficar dentro de hospital não. E velório também, até velório. Eu não me sinto bem quando... vou, não me sinto bem não. Não gosto muito. Dia de finados não gosto de ir no hospital, tenho o sentimento mesmo, choro em casa, rezo pra pessoa em casa, mas de eu ir em hospital pra ficar... em cemitério pra ficar... Cemitério é... nunca gostei não... e visita em hospital também, não sou muito fã não... não me sinto bem não... Eu rezo pra pessoa em casa, faço minha rezinha e cabou. Nada de visitas.

A única ansiedade que eu tenho agora é enxergar. Porque o médico me falou que eu não vou voltar a enxergar, mas eu ainda tenho fé... Que eu vou enxergar. Ainda tenho fé que eu volto a enxergar, pra mim andar só... No modo de falar... Pra mim ser independente, não é que vou deixar de ter meus companheiros, minha família, de visitar... É não depender, se eu quiser ir ali: pá... não preciso... Essa vontade que eu tenho é isso. Te juro mesmo, dia a dia eu penso... Eu já chorei, tem dia que eu choro, pra mim mesmo, ali dentro [aponta seu quarto], da ansiedade de enxergar, vontade de divugar as coisas. Porque eu divugando, eu consigo ir até ali, desviar de uma moto, desviar de um carro que vem, ou uma coisa... Só isso que eu peço a Deus. A vontade minha que eu tenho é essa, de ver você, por exemplo...

A ansiedade é grande pra... É o que dá mais desgosto, desgosto assim, no termo da pessoa é isso... Você querer muitas coisas e não... Até roupa quando vai comprar pra mim, puta merda, meus filhos que compram. Eu pergunto até pra ela [esposa] como é que está a camisa que eu estou vestindo, mas eu digo: "Bom, será que está do jeito que eu? A cor, será que está do meu gosto?". Até 
pra vestir você, é problema; pro deficiente visual é fogo. Ainda mais eu que sou vaidoso, pra mim eu tenho que estar todo arrumado. Se tem uma mancha na camisa, pra mim eu já estou pelado. Então já não gosto. Pro deficiente, pra mim, é muito difícil.

Tudo isso eu pergunto pra ela, quando eu calço aqui. Quando chove, as vezes que eu saio, e no dia seguinte se eu vou repetir aquele sapato... Peço pra ela olhar o óculos até, se tem mancha... Se você enxerga, você no espelho, você está sabendo se você está contente com seu visual... Isso aí eu sinto muita falta, porque eu sou vaidoso. No espelho, olhar, vestir uma roupa...

No meu tempo de solteiro eu não repetia camisa. Só que era outro ambiente, eu só saía para trabalhar. Então sim. Mas aqui agora... Aí ela [a esposa] só chama atenção? "Onde você vai? Vai sair da Cohab?. Não importa se eu tô na Cohab. [...] Coloco uma camisa, não isso aí não é camisa pra usar na Cohab...

Mas me vê aquela camisa que sempre a gente vê elogio: "Nossa a camisa bonita..." ou "que óculos bonito você está...". O óculos eu ainda sei, mas a camisa não sei qual é que é. Aí eu procuro saber qual que eu tô aquele dia, que aquela pessoa elogiou, pra repetir. Não no mesmo dia, mas...

Domingo mesmo eu fui - Não, foi domingo retrasado. Eu fui num aniversário e aí tem uns cara lá que falou: "Nossa meu, você com essa roupa aí, você fica parecendo um garoto de trinta e cinco, quarenta ano...". Falei: "Pô, então essa é a roupa...". Os caras me elogiando.

A gente não enxerga mas fica naquela de... Então essas ansiedade sempre dá na pessoa e isso é uma falta que sente. Pô, gostoso é você ir pentear o cabelo diante de um espelho, você está sabendo se você penteou, ficou legal. Porque você está enxergando. Agora, quando você não está, você já fica naquela dúvida: será que ta bem o penteado, o cabelo? Todas essas coisas incomodam o deficiente. É assim a vida do deficiente. E vai levando, vai levando, vai se virando.

Vai encontrando jeitos de suportar. Que não é fácil, não é. No começo eu sentia muito nervosismo por causa disso, porque eu não me conformava, a razão de eu não enxergar. Eu sempre gostei de trabalhar, de fazer as coisas. Agora, tem muitas coisas que você precisa de ajuda, fica muito dependente mesmo. Quando você tem uma pessoa que te compreende, aí dá pra você ir levando, mas se você pegar... que eu já vi tanta gente reclamar de não ter atenção... Eu digo, deve ser dolorido.

Porque, que nem esse rapaz mesmo que eu falava, que andava em cadeira de rodas. Puta merda, já pensou se ele não enxergasse ainda ter que ir andando, dependendo de cadeira de roda? Tenho que me dar por contente, ainda tenho até colega pra conversar... Tenho amigos ainda, ainda tenho, aqui no prédio todo mundo gosta de mim. Eu saio ali fora, eu acho sempre alguém pra conversar.

Eu tenho até uma colega aqui que ela é muito doente, aí ela falo pra ela assim: "Ah você reclama muito, tem gente pior do que você ainda aí...". A gente está ruim, mas tem gente pior. Por isso é que você tem se conformar também, tem gente pior. Por isso é que você tem que se conformar também, não é só reclamar não. 
(...) Por isso que eu digo: "Você fumou muito tempo, se prejudicou, você que se prejudicou mesmo, então não pode agora ver uma pessoa fumando e desce o pau". É melhor você aconselhar.

Pois é, Marilia, vai se levando. A entrevista foi muito boa, muito proveitosa. Gostei de ter participado. Tava falando pra minha esposa - hoje comentei com ela - é legal conversar, e tal. Uma distração também. E se precisar um dia, que você for fazer uma palestra assim, que quiser me convidar pra mim participar, se eu tiver condições eu vou. 


\section{"Eu quero viver..." - A história de Ricardo}

Eu tive poliomielite com dois anos e meio, no meio rural em Minas e, depois, eu soube que foi até uma forma de contágio da poliomielite por falta de saneamento básico. Depois que eu tive um pouco mais de liberdade pra buscar conhecimento, então aí eu acabei descobrindo que foi aí um mero acaso do destino e coisa e tal... Minha mãe veio pra São Paulo buscando tratamento, e a pólio deu uma piorada, porque deu junto com bronquite. Então, talvez por isso aí minha mãe se mexeu tanto pra me transferir pra São Paulo... vim parar aqui no Hospital das Clínicas. Desde os dois anos e meio fazendo tratamento... Aqui que foi diagnosticado a poliomielite, porque em Minas não, e aí acabei parando aqui no $\mathrm{HC}$ e os meus tratamentos... Olha, tô sem cirurgias faz uns vinte anos, que pra mim é um grande alívio. Foi uma opção minha depois, quando adulto, falar: "Não, chega... Acho que tá bom, né? Tá bom do jeito que tá, eu vou tocar a minha vida do jeito que tá...

Da fase de criança, lá em Minas, me lembro, depois puxando pela memória assim, muito vagamente, que eu cheguei a andar. Lembrei numa certa época sim, da minha adolescência, de uma bola; e, aí, minha mãe guardou essa bola e me mostrou. Vinha uma lembrança de uma bola vermelha, e me mostrou a bola vermelha, velhinha e tal... Ela ficou até emocionada... Essa é a lembrança que eu tive, que eu já corri atrás de uma bola, ficou só vagamente essa lembrança. Nunca experimentei uma marcha sem auxílio de nada; cheguei a ter marcha com auxílio de órteses.

Mas só que a pólio pegou a coluna, deu escoliose, e eu acabei perdendo as cirurgias que já haviam sido feitas, mais de dez cirurgias. Aí me propuseram no HC de refazer todas as cirurgias, tirar todas as deformidades possíveis, e colocar o aparelho de novo, pra eu ficar na cadeira de rodas, e eu acho difícil pra mim. Eu queria viver um pouco mais, queria respirar um pouco mais, não queria continuar fazendo cirurgias, o resto da minha vida. Envelhecer... Há uns vinte anos que eu falei: "Não, tudo bem, não quero fazer mais cirurgias, quero viver...". Agora eu vivo, de uma certa forma.

Além dos tratamentos, na minha infância eu me lembro de voluntárias de rosa, aquelas senhorinhas que iam lá fazer visitas, me levavam gibis. Então a minha infância foi assim, lendo gibis, no HC mesmo. Quando eu não tinha dor, aí eu procurava ver as figuras e ler um pouco; mas quando não, rasgava, jogava tudo.

Fiquei internado muito tempo, quase toda a minha infância, mas alguns fragmentos, que eu não tava lá, eu tava em casa, com a minha mãe. Porque teve uma história assim, de eu começar o tratamento com a minha mãe, e depois entrar uma instituição, que me acolheu; porque minha mãe não tinha condições dela trabalhar e todo dia, toda semana, me levar no HC buscando vaga, pelo SUS. Fui parar numa instituição em Cotia, de padres. Então, minha infância também foi passada lá, a adolescência. No comecinho da adolescência, conseguiram me colocar as órteses, consegui ter marcha; disseram: "Não, então você já ta mais ou menos reabilitado, volta pra sua mãe...". E aí, volta pra sua mãe, onde que minha mãe estava? Minas de novo, meio rural... Foi lá que a pólio deu uma avançada, pegou a coluna, eu perdi as cirurgias. Não por descuido dela, mas do próprio meio de vida, que não tinha condições de trazer de novo, pra fazer visitas periódicas, pra ver se tava avançando ou não tava. Já havia sido diagnosticado que no futuro eu poderia ter problema na coluna, que eu teria que 
estar próximo aqui do $\mathrm{HC}$, mas é o meio de vida pra ela, então, eu acabei parando lá e depois perdi tudo.

Cheguei aqui em São Paulo, já na adolescência de novo. Me trouxeram no Hospital das Clínicas: "Ó, lamento informar, mas agora você já entende... Sabe porque você não consegue colocar o aparelho? (...) Porque você perdeu as cirurgias...". Foi um choque né? (...) "Você tem umas três pra fazer, da coluna... você tem que fazer... agora, as outras vai ficar pra você decidir...". Aí foi meio nesse tempo que eu já tive a minha maioridade, e eu que tive que decidir, e eu falei não, chega... Dá um basta...

Foi meio traumatizante... Eu acho que não foi nem da adolescência, porque na adolescência eu já tinha até uma aceitação, agora na infância não... Não tinha muita aceitação de fora e tinha uma coisa minha também, que eu via muita barreira. Não podia brincar como os outros, aprontar como os outros, não podia, tinha limitações. Então isso que me deixava frustrado, eu tive essa crise de adolescência muito mais cedo, acho. Tive que amadurecer muito mais rápido, acho que a própria vida me impulsionou a isso.

É isso aí que chateou, e como que ia buscar o alívio né? Não foi droga, mas foi álcool... Álcool muito fácil, comecei a me viciar no álcool. Graças a Deus, é que a gente vê outras realidades e eu fui aprendendo. Se eu continuar desse jeito, eu vou morrer, não tem jeito. Eu vi outros amigos que não vieram com essa mesma deficiência, mas que ficaram, e convivendo, falaram: "Pra mim eu não agüento essa realidade, eu quero morrer...". Então eu vou tirar o álcool dele, tirar ele do meio do convívio, colocaram em enfermaria, mas aí bebia álcool da enfermaria. Então foi graças a Deus... Hoje em dia, nada, nenhum vício, nenhum tipo de fumo, de bebida, não tenho, graças a Deus.

Meus amigos eram todos lá na instituição. Eu lamento até ter perdido esse contato, familiar. Tenho irmãos, hoje não convivo com eles; éramos em cinco, faleceu uma irmã, o ano passado de câncer e, agora, somos em quatro. Todos os outros três casados. Eu, por uma opção, optei por não casar, não constituir uma família; eu também acho que não fui pro convívio deles porque eu acho que eu sou auto-suficiente, consigo me bancar. Quero ter a minha vida... Porque aí a gente volta de novo lá naquela questão de que não fazer mais cirurgias. Não, eu quero viver... então você tem que bancar. Então foi por isso que não tenho assim o contato e tal, mas não sou muito de freqüentar e conviver... (...)

Tenho ate essa questão de não encostar, que eu acho que foi até bom. Pela política que era colocada pela instituição: "Você vai sair... No seu caso, você optou por não fazer mais nada... Então você vai sair, vai pra sua família...". Pra Minas? No meio do mato? Qual o meio de sustento lá? É trabalhar na roça... Como é que eu vou entrar lá? Não vou, não vou entrar lá nas ruas, não dá. Não, eu preciso ficar aqui. Tentaram me mandar para o meu irmão, graças a Deus uma cunhada: "Não, não tem cabimento, nós não temos condições...". Falei: "Então vou ter que me bancar...". E não fiquei triste por isso. E como eu me banquei? Tive um apoio, lógico; de uma família que visitava a instituição...

Uma senhora precisava trabalhar e falou: "Olha, tô precisando de uma pessoa para ficar em casa quinze dias... mas você tem paciência com criança e tal...". Falei: "Ó, vocês me conhecem aqui da instituição, não conhecem?". "Conheço...". "Então...". Porque eu saía do convívio dos maiores; nos momentos de stress, eu ia no meio da criançada, procurava entender, conversar com eles, cada um diferente do outro. E aí eles me analisaram, e, por isso, falou: "Ó a 
gente viu que você tem paciência com criança... e tá precisando... quinze dias... tudo bem?" (...) "Ah, tudo bem...". "A gente soube que o padre quer mandar embora, já tava mandando uma leva de pessoas embora, então você não quer vir? Vem...". E foi aí que começou.

Hoje em dia tenho uma certa liberdade. Não tenho totalmente porque eu ainda não tenho a minha casa, minha casa mesmo. Moro nos fundos de uma residência, que é um sobrado e tem uma casa no fundo; e aí tem o meu quartinho lá. De uma certa forma tenho uma liberdade. Barrei muito, e barro ainda, influências dos meus irmãos, querendo: "Não, faz isso, faz aquilo, vem pra cá, vai pra lá...". Não, eu barro muito; barro muito na medida do possível. "Mas você vai quebrar a cara...". Vou, mas quero experimentar e, assim mesmo, a gente vai tocando.

Fazem uns seis anos que eu consegui entrar no mercado formal [de trabalho]. Porque até então, não trabalhava formalmente. Era artesanato, sapataria... Ganhava razoavelmente pouco, e não é valorizado. Trabalho artesanal não é valorizado. Isso em casa. E aí houve uma abertura do mercado, por conta da lei, (e a gente até questiona isso também); abriu-se, mas ainda tem muita barreira, ainda a gente vê que tem muita.

Eu tive uma oportunidade de entrar como operador de telemarketing, não sabia como é que era isso, fui fazer a entrevista: "Ó... você tem perfil meu...". Caí lá como operador de telemarketing e venho caminhando, buscando sempre uma evolução, mas nem sempre essa evolução chega. Porque aqui é o CAT, ainda tô no head. Faço um telemarketing mais diferenciado, porque na verdade eu tenho a vaga e tenho o banco de dados; então eu faço cruzamento, e vai correndo atrás dos candidatos, convocando pra uma seleção. É uma pré-seleção no telefone; então, quer dizer, já mudou o meu perfil de atendimento, é menos estressante.

O que me fez sair da última empresa - uma empresa muito boa, um plano de saúde muito bom também - é porque eu sou muito exigente comigo mesmo. Eu vi que já tava exigindo demais, eu já tava tendo que fazer algumas consultas, foi me passado um remédio de tarja preta, eu falei: "Não... Peraí... Então tem alguma coisa errada...". Então pedi pra sair e tô fazendo um ano agora, fiz agora em janeiro, e agora tô pegando a minha primeira férias, em abril. O mercado abriu, tá bom, mas você fica mudando muito, a gente tem que tomar cuidado com isso. Fica cinco meses aqui, sete ali, daí você não pega férias, não pega vínculo com a empresa. E graças a Deus tô aqui há um ano né? Mas, tá meio perigando também, por conta de fatores, de mudanças, mas não tão pensando muito no meu meio de locomoção. Então não tô muito contente... Veio pessoal do RH hoje, já falei...

Hoje, pra trabalho, eu tenho o serviço ATENDE, que é uma luta nossa, que é uma coisa que a gente sempre tá de olho, tomando conta mesmo. De uma certa forma, a gente toma conta desse serviço ATENDE, porque foi uma coisa que, não primeiro momento, há dez anos, doze anos, foi colocado e até hoje é um decreto. Sendo um decreto, não é lei. Se chegar alguém aí e falar: "Num dá pra gente cumprir", então... Mas nós estamos caminhando pra transformar em lei... Então, no dia-a-dia, pra trabalho, eu tenho. Agora, pra sair, não. Pra sair é ônibus. É adaptado, que também a gente cobra muito, cobra horário e cobra se não tá na linha... não tem outro não, não da pra correr não e é muita dificuldade mesmo. Não só de transporte, mas de barreira arquitetônica; tem muita... 
Graças a Deus que eu ainda tenho força, um pouco de força [faz um gesto mostrando as mãos] pra vencer essas barreiras. E inclusive a gente tem uma reunião com a subprefeita aqui da Lapa, pra falar desta questão de acessibilidade. (...) É dez minutos, quinze minutos da minha casa até o ponto, pra pegar o ônibus; tem que ser o ônibus adaptado, se perder aquele fica difícil.

(...) É complicado militar na área assim, porque você perde o sábado inteiro. Sou eu que cuido da minha roupa, que tenho que passar, lavar. Isso demanda tempo. E outras cositas mais: ver a namorada e tal, respirar um pouco... Se eu for só pra ir lá pra ver barreiras da comunicação, fica complicado, mas se entrar acessibilidade eu me sinto obrigado a ir. Porque é o dia inteiro, é terrível, você as vezes não resolve nada, você tem que estar lá. Você tem que fazer parte do negócio, porque de repente fala alguma coisa, acontece alguma coisa, você tá por fora... Então eu preciso...

A minha alfabetização foi meio complicado, porque vivia mais em tratamento, internado, do que um ambiente normal, que pudesse freqüentar a escola e tudo. Me lembro até que, no começo, eu era colocado junto com crianças com problemas mentais, e aí eu queria aprender a ler e falava isso pra quem tava instruindo, mas como era não atacadão, era todo mundo junto... Então a coisa foi indo, e não era só eu; tinha mais, outros ali... E eu não entendia essa coisa de problema mental. Depois eu fui entender que ia me ajudar no meu desenvolvimento, mas eu acho que isso ficou retardado... Hoje eu tenho muita dificuldade de assimilar muita coisa. Agora não sei se isso foi por conta de uma mística, assim, que popularmente as pessoas falam que tomar muita anestesia, ser apagado muitas vezes, depois você fica com uma certa dificuldade de assimilar de guardar muita coisa. E aí eu tenho essa dificuldade.

Hoje eu tenho ensino médio. Até a oitava série, tive um calço bom, mas o colegial foi supletivo. Isso depois da instituição, aí eu por minhas contas mesmo, supletivo à noite, fui indo. Quando deixavam tinha aula, porque na periferia é assim: se deixavam, tinha prova, quando não tava todo mundo com nota. E eu não podia falar nada. Eu tentei falar alguma coisa: "Ah, não... Mas, onde você mora mesmo?". E, por conta de eu ser acolhido, eu morei no Parque dos Príncipes [bairro de classe média alta, próximo ao Jaguaré], lá uma casa boa, um bairro bom, e mais ou menos que eles sabiam. A casa não era minha, como aqui hoje não é.

Sou muito de preservar; não é meu, mas eu tô utilizando, vou cuidar, não vou trazer ninguém tão estranho... Até você vir aqui hoje é uma novidade, porque eu não costumo receber ninguém. Seleciono bastante, pra não ter essa invasão. Eu tenho a minha vida fora daqui, lá encontro com amigos... Mas não da para você receber em casa, a casa não é minha. Então sempre sei diferenciar muito bem isso... Essa parte da educação ficou defasada, ficou mesmo. Hoje eu sinto isso no mercado de trabalho: aparecem muitas vagas, boas, excelentes, mas você tem que ter um nível universitário. E aí eu não tenho. O pessoal fala: "Não, porque você não vai, tem... tem banco, tem isso, tem aquilo...". Porque eu já testei, eu já fui fazer testes e tudo. Um tempo atrás era o ensino médio, hoje em dia não. Eu até penso em continuar estudando, mas aí eu teria que criar uma condição pra isso. $\mathrm{E}$, não sei se com o conhecimento que eu tenho, eu poderia tentar alguma coisa pública, porque eu sei que é mais puxado ainda pra entrar. E pra bancar, eu sei que é caro pra caramba.

Então assim, aí eu fico nessa. Se eu não tenho conhecimento pra tentar numa pública, eu tenho que ter renda pra bancar. Eu fico meio frustrado por isso, e 
tendo que aceitar algumas vagas que... Acho que podia estar melhor, podia estar numa parte administrativa, e a porta de entrada é o currículo mesmo, os seus conhecimentos. Então, não tem como não. Vou ter que aceitar ser colocado em call-center. Sei que isso não é indigno. É digno, é um trabalho digno, mas é aquela questão do stress que eu falei. Aquela parte do stress, aquela coisa de call-center, aquela loucura toda, você tem que dar uma saída pro cliente, se virar. Quando eu não posso arrumar alguma coisa, eu entrego meus pontos, falo: "Não, então olha, eu pude vir até aqui, sou honesto em afirmar, e tal, mas você tem capacidade...". Eu não consigo enrolar, daqui pra lá eu vou enrolar e aí eu não consigo, porque até eu tenho mais ou menos esse jeitinho. Por isso eu saí.

Começando da infância, com a historia do bronquite... Indo lá de Minas, de um local rural, praticamente quase no mato, e vindo com um quadro de bronquite, e juntamente com a poliomielite, que eles não sabiam diagnosticar... Minha mãe, é o que ela me contou antes dela falecer (hoje ela já é falecida): "Olha senhora, olha aqui a gente conseguiu diagnosticar o bronquite, agora essa outra coisa que ele tem, nós não sabemos, sinceramente aqui em Barbacena, Minas Gerais, nós não sabemos... A senhora conhece alguém no Rio de Janeiro?". A minha mãe: "Ah, não tenho ninguém lá, tenho uma irmã em São Paulo, na periferia de São Paulo...". (...) Vai a minha mãe, vir aqui. Foi aí que começou, cheguei no HC: "Ah, ele tá com quadro de bronquite, terrível, e tá com poliomielite senhora. A senhora sabe o que que é isso?". Minha mãe: "Não...". "É, então, a gente vai cuidar dele, mas dentro do que o sistema de saúde público pode oferecer, e tem uma fila, e tem uma coisa...". E foi indo, foi indo, passei a minha infância praticamente aí, parte dela com a minha mãe, indo e vindo, internando e fazendo cirurgia, e chorando pra caramba...

O que eu me lembro de infância foi muita cirurgia. Lógico que teve algumas passagenzinhas assim, de espaçozinhos mínimos entre uma cirurgia e outra, que eu tive alguns momentos com a minha mãe, e aí eu aprontava bastante. Minha mãe me tratava como um menino normal, porque aprontava, e depois, voltava de novo aquela rotina maçante, e cirurgias, e tinha que ficar em tração, tinha que ficar amarrado. Me lembro muito que eles tinham que me amarrar, porque eu tirei aqueles pesos. Tirei, porque doía muito, porque tinha que fazer tração. Então assim, a minha infância foi toda essa, em cirurgias, tudo.

Passei toda essa dificuldade e aí chega na adolescência, lá vem a questão da escoliose, as três cirurgias na coluna e depois aquela proposta de refazer todas as cirurgias: "E você vai ficar bunitinho na cadeira, sem deformidade.... E aí quem sabe você arruma alguém melhor, você não vai ter tanta dificuldade em conseguir alguém...". Foi mais ou menos isso que eu entendi. E aí não aceitei! Tudo bem, tem que fazer as da coluna, tem de qualquer jeito pra dar uma paradinha aí na escoliose, porque senão vai pressionar tudo, os seus órgãos, e vai ter problema pra respirar. Então, fiz aí as três cirurgias na coluna e dei um basta.

Eu dei um basta, porque... Tudo bem, eles tavam me ajudando, tem esse lado de me ajudar, mas tinha a parte acadêmica. Eu comecei a ver muito aluno, o professor fazia a cirurgia, mas quem fazia a visita era aluno. E isso ficou muito claro depois que já tinha uma adolescência, comecei a entender um pouco mais das coisas: "Olha só, então por isso que eles me acolheram, pra aprender...". Tive até um desconforto com um aluno, ele queria entrar um pouco mais na intimidade, brincar, que a minha dor que eu tava tendo ali, era meio que criação, fantasia. E não era né? Eu tava tendo muita dor; na ultima vez da 
operação, ele vinha brincando, e aí eu não gostei. Não gostei e falei: "Poxa, ué, ele é médico ou não é, né?". Aí vem a assistente social, coloquei a situação, aí veio o professor conversar (...) e ficou essa situação assim. Talvez ele quisesse fazer a visita, e ao ver o paciente lá com dor e tudo, brincar pra tentar fazer com que eu esquecesse, mas acabou que eu não aceitei muito isso não, porque quem tava sentindo dor era eu, e quem queria ter mais, um pouco mais de medicamento pra amenizar a dor era eu. Então tive esse desconforto...

Eu me lembro que, era colocado assim, que eles podiam dar medicamento até um certo ponto, e o resto eu tinha que agüentar. Eu acho que não... Achava que não... E, da última vez aí o professor falou: "Você ta tomando uma medicação que era pra te deixar anestesiado, só se a gente apagar você...". (...) Então foi essa aí, essa passagem no $\mathrm{HC}$; mas antes, bem antes de eu chegar no $\mathrm{HC}$, eu passei na $A A C D$, que era ponto de referencia já naquela época. Aí a $A A C D$ fez também, ajudou nesse diagnóstico, porque eles tinham condições pra isso e também encaminharam, de certa forma, pra que eu entrasse no HC. Porque bater assim de cara, acho que não daria não. E o que eu vejo hoje também não é isso, que a gente chega e entra, não é isso. Então acho que aí eu passei pela $A A C D$, a AACD diagnosticou e o $\mathrm{HC}$ acolheu e fez todo esse tratamento...

Quando eu perdi, eu já, por entender, falei: "Não, quero uma segunda opinião...". Aí lá o colégio: "Não, não, mas é você, eles deram o diagnóstico, é esse mesmo...". Falei: "Não... Eu tenho direito, eu quero saber...". Aí me encaminharam pra Santa Casa. Foi feito lá também uma junta médica, pegaram todo o histórico, tudo... "Ó, é realmente isso mesmo... Os caras lá não tavam mentindo não. Você perdeu mesmo... A gente só não concorda de fazer tudo de novo, pra você ficar na cadeira, que é o que eles afirmaram pra você. Então, a gente não concorda com isso, você vai passar por todo o sofrimento...". E aí eu perguntei: "Ah, vai ter tração de novo?". "Vai, claro, claro que vai ter, porque ficou deformado... (...) o que der pra gente tirar em cirurgia, a gente vai puxar, mas o que não, meu amiguinho, você vai ter que ficar. A gente pode fazer isso pelo SUS pra você, tem uma fila de espera, a gente pode fazer, se você quiser. A gente não indica, porque é um sofrimento; você ta aí, já terminando a sua adolescência, já ta na sua maioridade. Era bom você viver um pouco...". Até mesmo o pessoal da santa: "Não, vai viver meu, vai estudar. Como você já teve todo esse histórico aí de cirurgia desde criança, então agora não, vai estudar, ver se foca um pouco mais no estudo, pra você começar a ter a sua vida, quem sabe você pode constituir uma família...".

Então teve essa passagem, e última minha passagem foi na UNIFESP, no Hospital São Paulo, há cinco anos. Eu tive um susto muito grande, porque eu tive poliomielite, não sabia que existia a pós-pólio. Aí eu vim saber que existe sim, que desde lá na historia do presidente Roosevelt, que ele tinha poliomielite... Foi lá que começou aquela história toda dos cientistas e dos estudiosos acompanharem aquela história e saber que por ele ter tido pólio, ele foi perdendo força. E nos últimos tempos dele, ele foi parar numa cadeira. Então isso aí me chocou muito, me assustou muito... Putz, pensei que tivesse tido pólio, acabou. Tô com essa deformidade, acabou, pronto, consigo tocar minha cadeira, tenho dificuldade, mas beleza. Não, não é assim...

E esses pacientes que primeiramente passaram lá na infância, tiveram atendimento e, depois, é o que eles mesmo me colocaram ao longo da história: "Não você teve pólio, mas daqui pra frente vida normal... Cabou você saiu daqui, cabou...". Então assim, tive uma grande decepção, até pra falar disso me dá até um certo medo assim, uma coisa... [longo silêncio] Porque eu vi que eu comecei 
a perder força, perder força... Assim, de pegar coisa, e via uma subida, uma rampa com a cadeira, e ir, falar: "Poxa, será que é o peso da minha idade...? Tá pesando muito, pesando muito rápido e tal...". Foi aí que eu comecei a tentar ver... tô pegando muita virose e depois de um esforço que eu faço, de tocar a cadeira, no outro dia me dá uma dor no braço, umas coisas...

A pós-pólio, lá na UNIFESP, tem lá uma associação agora, a ABRASPP. Aí me assustei lá, fiz todos os exames lá, a coisa não tava tão avançada em mim, porque eu tinha trinta e cinco anos. Agora eu tenho quarenta, e aí eu resolvi esquecer um pouco disso lá. Se eu vou ter síndrome pós-pólio, vou, já sei disso, deixa isso pra lá. Agora, ficar muito encanado lá, indo lá na UNIFESP pra ver os outros pacientes que... (...) os pacientes já tão com balão de oxigênio, porque os músculos não conseguem puxar mais ar. Eu sei que eu vou chegar nisso. Então não quero ter, um contato com isso agora. Antes do tempo... Isso que me preocupa, me preocupa muito. Quero ter, procuro ter minha vida independente, e dependo sim de um monte de gente, acho como todo mundo depende... Eu mais um pouquinho mais. Procuro ter a minha vidinha assim, até quando der. Me chocou muito essa historia da pós-polio, que aí eu fui correr atrás... (...) Ah, deixa pra lá... Deixar correr, deixa correr, eu vou tomando aí vitaminas C, pra não ter tanta virose, tanta coisa. Vou vendo se a rampa tá muito forte, ou eu não vou, pára na metade do caminho, peço ajuda, se não tiver volto...

Vou tentando controlar a minha cabeça mesmo, porque eu vejo uma coisa, eu sei que eu posso com ela, eu sei que posso, mas de repente o corpo aí já não tá respondendo. Então tenho que lidar muito bem com isso. Queria fazer algum esporte, já orientaram, desde aquele tempo: "Aquilo que pregaram pra você... Você teve poliomielite, tem uma deficiência. Então você tem que se superar você tem que fazer um esforço a mais. Se você fizer musculação, se você fizer isso, fizer aquilo, a parte que não foi afetada vai ficar bombadão, vai ficar fortão... E aí com isso você vai indo, meu...". Veste aí uma capa de super-homem, e é uma coisa que a gente precisa trabalhar muito bem. Acho que a pessoa com deficiência, hoje tem que tomar muito cuidado com isso, porque ela pode passar duas imagens. Tem que se atentar pra isso, no contato com as pessoas. Se você, tiver passando uma imagem de super-homem, mulher-maravilha, você tem que se atentar; agora se você tiver passando uma imagem de coitado, também você tem que se cuidar. Você tem que tomar cuidado com isso. $E$ às vezes, você ta assim numa relação, numa convivência, quando você percebe, você tem que dar uma podada. Tem que chamar: "Ó, psiu... Não é bem assim não gente, ó...". Você ta passando uma imagem de coitadinho tal, não... Eu sou capaz ó....".

Dizia: "Ah que bunitinho, tal...", quando eu era mais novo, as meninas. "Ah, mas pena que usa cadeira...". Já escutei assim um comentário. Já, mas é fofinho, mas poxa não dá pra sair, não dá pra fazer nada. Então escutei isso... Escutei pessoas que chamam de inválidos. E aí eu preciso lidar muito bem com isso também, até hoje não lido muito bem, não consigo digerir isso... Eu fico até meio agressivo... Porque se eu vejo que a pessoa tem uma instrução, e ela tá me chamando de coitado pra me deixar lá embaixo... Se eu vejo que é uma pessoa que não tem instrução e tá me chamando de aleijadinho, dói, mas dói muito... Mas aí eu vejo, olho pra pessoa, falo: "Ah, coitado, mas ela não tem instrução, não vou agredir ela não. Deixa ela, um dia ela aprende...". Fazer o quê, isso aí me dói, dói... Acho que a própria condição que tô hoje é pra que eu aprenda, que eu tenho que aprender um monte de coisa... Acho que se não tivesse numa cadeira, eu ia ser uma pessoa muito prepotente. E aí aqui não, debaixo tem que enxergar um monte de coisa, um monte de detalhes aqui que... 
Tive tudo naquele primeiro momento lá, quando eu acho que tinha alguma solução, eles podiam visualizar aí uma melhora. Depois daquele estágio que, acho que já deu, acho que não vai evoluir mais pra mais, você já perdeu tudo, as cirurgias então tal... Meio que deixaram assim, não interessa muito. Eu fiquei muito chateado aí com a AACD depois da síndrome, porque eu tinha ido, quem tem estrutura pra dar um apoio psicológico, alguma coisa, era ela... E aí, ela falou: "Não, nosso foco não é esse...". Qual é? "É criança que a gente vê que tem um futuro, que vai ter uma evolução, agora vocês adultos, vocês tem quem voltar, vocês vão ficar na fila...". Hoje eu sou uma pessoa muito ansiosa, então você vai ficar nessa ansiedade, então melhor saber que não pode contar. Sinto que poderia ser acolhido melhor, mas não é isso que a gente vê...

Hoje eu tenho plano de saúde, da empresa. Pago um que cabe dentro das minhas possibilidades, por fora. O pessoal: "Mas ô você... você tem da empresa, mas você paga o seu...". É, o meu é o meu, eu tinha antes de começar a trabalhar... (...) Então tenho ele hoje, tenho esses dois. E a gente vai nos PS da vida aí; mas só vou nos PS da vida quando trava alguma coisa, porque a coluna trava, dá um problema de sinusite, porque eu tenho as ites. Aí bato lá, e graças a Deus, que eu posso bancar isso hoje. Posso bancar um tratamento dermatológico, de uma doutora na Lapa que me trata com remédio manipulado, que ela pode por menos dosagem, mais dosagem. E aí eu posso pagar uma receita, que muita gente não pode. Duzentos reais, uma receita, não é todo brasileiro que pode bancar. (...) E hoje, graças a Deus, posso bancar isso. E isso me assusta, porque e se eu não pudesse? Já procurei os postinhos...

Foi até bom começar a trabalhar, porque aí não tenho tanto tempo pra pensar na pós-pólio. Arrumo outras encrencas, acho outros pepinos lá e aí vai. É, vai discutir com o gerente, com o supervisor, vamos mudar e você vai perder o serviço ATENDE, você vai ter que pegar o ônibus das cinco da manhã e pegar metrô. Então é outra coisa. Aí eu vi que entrando nesses movimentos de saúde, podia colher um pouco mais de informação, saber os caminhos. E que agora, eu perdi, eu perdi um pouco disso, porque era reunião direto e agora não dá... Às vezes acontece reunião duas horas da tarde... Aí tem uma outra amiga, que fez essa reunião, que é uma perna do nosso conselho municipal da pessoa com deficiência, que agora tá desvinculando, tá indo nos bairros, fazendo as reuniões lá, colhendo a demanda e pra trazer pro conselho, pra jogar lá e falar: "Ó, tá aqui... É isso aqui, na área de saúde, educação, acessibilidade...". Então teve essa reunião lá, eu passei por lá.

Isso também me ajudou bastante, o mosaico [aponta peça que produziu em oficina de mosaico] também me ajudou nessa parte psicológica. Era uma atividade que ia lá, encontrava estagiárias, até ajudava, dava uma dica aqui outra ali. E via que tinha pacientes que, se não fossem lá, não iriam sair de casa, e graças a Deus que com essa coisa, a gente conseguiu trazer o ATENDE pra lá também. Tornou-se uma coisa assim meio já constante lá, aquele trabalho lá. Com o apoio da USP, que dá força lá, pra tocar aquele trabalho, porque se não for, se a gente for esperar o governo, não tem orçamento. É isso que eu sempre escuto: "Ah não mas a saúde, o postinho lá não dá pra, pra adaptar, não dá pra fazer? É não tem orçamento...".

Nesses movimentos, eu via uma coisa que me assustava muito, que é fila de espera pra certos exames aí de seis meses, sete meses. Porque nesses conselhos municipais de saúde, teria que ter um representante de cada segmento da sociedade. E eu via que os outros tavam bem mais estruturados, estão... A gente pode ver aí pela história do idoso, é bem organizado, eles iam 
tal, nossa brigavam feio. E aí a pessoa com deficiente já num... É, eu tinha que ir lá e aprender e brigar e por várias vezes falei não... (...) O sistema de saúde deixa muito a desejar, acho que pra todo brasileiro. Aí eu sinto meio injustiçado, não só eu, mas acho que toda pessoa que já adquiriu, a sua deficiência, que de certa forma aí... não vou falar nem os que adquiriram agora, que eu acho que tem uma diferença... Acho que a sociedade, todos nós, temos dar um jeito de ver todo mundo, por igual, é todo mundo deficiente; ou adquiriu de criança, ou foi uma doença, ou foi acidente, que a maior parte agora é. Aí a sociedade toda vê todo mundo como um todo né? Ah tudo deficiente, é tudo do mesmo jeito, todo mundo teve a mesma oportunidade, de estudar... Então, não é assim, eu defendo que não é...

Porque eu já vim de criança, então minhas oportunidades foram diferentes do que aquele cara que já tinha uma, uma vida de motoboy ou sei lá, mas caiu e se acidentou, ou tinha o seu carro bateu e não sei quê, e ficou paraplégico... Mas aí já tinha suporte, tinha uma vida, um trabalho... Aconteceu há dois anos, o cara já tem um carro adaptado, o cara foi colocado de novo no mercado de trabalho, continuou lá na empresa dele, foi até promovido. Tem essa coisa de ser tratado todo mundo assim, daí eu vejo que: "Pô por que você não vai lá cara? Por que você não tem o seu civic? Meu, você ta sofrendo porque você quer...". Hum, tá. não é assim, eu sei que não é assim. Isso me magoa muito, chateia muito e sempre que posso, eu falo dessa diferença. Tem, existe sim, muita. "Ah, poxa, mas tem a fulana lá que, puxa, ela é tetra [tetraplégica] e ela tem uma vida, ela ganhou a secretaria, da pessoa com deficiência, ela assumiu como vereadora... Tetraplégica... Poxa, e você que mexe aí tudo cara, ô... Você ta marcando touca...". não é, né? Então tem essa parte financeira também, de suporte tem que ter, ô como tem...

E eu vejo que pruma coisa que eu consigo manter, que é essa cadeira aqui um pouquinho melhor [aponta uma outra cadeira de rodas, não a que está sentado no momento], não é o ideal... Não é o ideal que prescrevem pra mim; o fisioterapeuta, o terapeuta ocupacional foi lá na empresa, ele viu: "Não, mas essa almofada cara... Mas por que você tá com a perna cruzada? ... É notei, desde que eu tô aqui com você tá perna cruzada ou você tá encostado...". "Ah, é porque dói, meu. Dói, dói... Eu tenho sensibilidade. não sou para [paraplégico], então dói". Ele fala: "Então deixa ver essa almofada... Não, não pode, você tem que o apoio, tem que ter o ângulo...". Eu falei: "Ah tá, tem que ter...". E ele: "É, você tem que usar uma almofada..." . Eu falei: "Ah tá, sei qual almofada...". E ele falou que é meio que uma marca que custa mais de dois salários mínimos a três: "Mas essa seria o ideal, você conhece?". "Conheço, puxa até peguei nela já, na feira... Mas é caro, e uma coisa que eu posso bancar é essa cadeira". A pessoa fala: "Ah, mas você ta com a roda estilosa agora?". "Não...". "É, mas é bonita, estilosa...". "Não, mas eu não vejo por isso, vejo um pouco mais leve...".

E é o que o pessoal da UNIFESP falou da pós-pólio: "Você larga essa cadeira de xis porque, essa cadeira de xis, pra você se locomover você precisa um pouco mais de força, ela pesa um pouquinho mais... Então pega uma de quadro fixo, você conhece a cadeira?". "Ah, eu conheço, eu tentei aprender basquete... Sei o que que é...". "Mas você sabe que tem coisa leve?". "Sei... Mas e cadê [sinal de dinheiro com a mão]?". Até que o pessoal da UNIFESP prescreveu uma cadeira, assim assado, pro SUS. Eu bati, bati, bati no SUS... Eu fiquei sabendo que ia sair a cadeira, mas não era desse jeito. Ah, se não é pra sair desse jeito. Saiu mas eu doei; eu peguei e doei. Alguém aparece, sempre os outros sabem que tem alguém que tá precisando, aí doei a cadeira e consegui essa aí. E o pouco que eu posso, eu invisto nela. Sei que preciso de uma melhor, mas essa é a que 
é possível agora no momento. E não tenho capacidade de ir na Reatech ou comprar ou levar a cadeira.

(...) Eu fui lá, vi a cadeira, a cadeira tava em torno de cinco mil reais... Só posso comprar essa daqui, que um par de rodas aí, que é um salário mínimo e meio... (...) Então assim, eu vejo que preciso de uma cadeira melhor, preciso ter um acesso melhor ao sistema de saúde, a uma hidroterapia, a um acompanhamento psicológico até. Mas, não tenho, não tenho. Vou vivendo assim...

[Para fazer exercícios/academia] Precisa ter uma orientação, é o que eles me falaram lá; você não pode sair por aí fazendo um monte de coisa aí, que você acha que vai te ajudar, levantar peso pra ganhar força e tal... "Num é isso, você tava fazendo errado cara". "Ah é doutora?". "É...". Ah, eu tava lá, comecei com um quilo, já tava com três quilos, fazendo, porque eu acho que tava perdendo força. Ele falou: "É, você tava queimando mais ainda a sua reserva...". E é isso que a pós-pólio faz, vulgarmente, popularmente, o que eu entendi é isso. Então você tem que procurar alguma coisa e específica e não tem, e tá vivendo assim.

[Fora dos tratamentos] Busquei a escola, que era na instituição mesmo. Fiz prova até numa cadeira que é maca, segurando folha assim [faz gesto com a mão]. Porque, graças a Deus, os professores não tratavam com diferença. Era uma escola que recebia alunos de fora, então, mesclava todo mundo, e a maioria era de fora mesmo, que o Estado bancava. Busquei a escola, e achava que a escola ali iria me ajudar - e como ajudou - ter uma perspectiva de tentar uma universidade pública. Aí depois, entrou essa questão de uma outra coisa que não ficou bem resolvida, depois que eu saí que ficou resolvida, mas que me atrapalhou bastante foi aí no momento da escola ter que sair da instituição.

E viver com essa coisa da ansiedade; não foi trabalhado muito bem essa saída da instituição. Tinha psicólogo, tinha assistente social, que na ponta final foi ela que colocou todo mundo pra fora, e me colocou também. O que eles tavam propondo era colocar numa perua um grupo, fazia uma rota, e ia entregando aqui em São Paulo. "É, o tratamento já se deu, não vai evoluir mais do que isso taí...". "Não, mas olha eu não tenho condição financeira, não tenho estrutura, não tenho...". "Ah não tem? Mas é filho, cuida...". Então vai ficar na rua, e aí muitos aí é... Acho que poucos a família recusou.

Sai mais estruturado porque tive um respaldo melhor pra estudar, alimentação... Tinha tudo lá dentro, na instituição, tinha tudo e não tinha nada, porque é um mundo fechado. Um mundo fechado, um mundo de certa disputa até, por viver não ambiente de instituição, não ter o lado da família, o carinho da família, e você ter que se tornar forte pra você continuar vivendo lá dentro.

É diferente na hora que eu sai. Eu me sentia, de certa forma, livre. não tenho que prestar contas pra padre, pra seminarista, não tenho que dormir na minha cama, e deixar um nada ali pra me defender, que eu pudesse pelo menos imaginar que eu pudesse me defender não caso de um surto de uma pessoa, um colega que tivesse problema mental... E um monte de outras coisas, poder receber alguém... Isso lá não tinha, você tinha que receber visitas assim no atacado. Sua família vinha te visitar, o meu irmão vinha me visitar, tinha que ser no meio de todo mundo, ele queria ter uma conversa, mais particular, alguma coisa, não podia. Poder namorar, não podia, mas se namorava, lógico, que era até uma coisa meio que lógica de acontecer. 
Lá na instituição é uma grande fazendona, tinha pavilhões... Então tinha o pavilhão dos maiores, menores e as meninas. As meninas, por conta até de ser mulher até que tinha divisão, mas era o mesmo pavilhão. E lógico, que a gente acabava se relacionando com as meninas, lá dentro. E as grandes paixõezinhas assim da vida lá... Mas, muita coisa vinha de fora, que a gente tinha contato da escola. Eu mesmo cheguei a ter os meus namoricos. Vendo assim, até hoje, poucas meninas com deficiência; não é uma coisa colocada por mim, não é preconceito meu, não é... Até depois aqui fora, uma amiga que ficou a fim, ela até jogou pra mim: "Ah, porque você tem preconceito né? Você não quer namorar outra cadeirante né?". Falei: "Não, não é isso... (...) é porque eu sou antigo mesmo...". Eu digo que me amadureci muito cedo, colocar valores que muito cedo... "Ah, mas não... Deixa o valor pra lá, não sei que...". "Num dá, tenho minha namorada...".

Num era [a cadeira], e ela queria colocar. Sempre já colocaram isso, até os próprios colegas: "Você tem preconceito...". Não tenho, não tenho. Já me relacionei, mas hoje não é o caso. Hoje, a gente tem uma relação assim há mais de cinco anos, só não é casado. Porque até mesmo uma coisa que eu coloquei, pra mim: não quero, não tenho condições. Muitos falam: "É que você não quer, porque se você quisesse, se você ver criança...". A princípio, quando eu tava na instituição, eu queria ter a minha família, ter filho, vai poder, vai... Quero adotar uns dez, montar uma casa, essas crianças abandonadas e tal... Eu sai, eu vi, a responsabilidade é grande, não é assim não... É uma responsa muito grande, porque você não pode pegar ou trazer, e depois você jogar pro Estado. Eu não entendo muito isso, não é muito resolvido, pra mim, então acho que não... Se não tem condição, não tem condição. Aquilo que eu falei da cadeira: você pode bancar até certa coisa por si, pode. Então ta bom, passou daí pra lá, não. Não, não mesmo. Sou meio realista, não tem essa não.

E essa coisa do SUS, voltando lá no SUS de novo e não poder ser acolhido de novo, isso que me deixa chateado mesmo. E de ver que a coisa ta tão difícil, tão sofrida, pra maioria das pessoas, e o pessoal que tem uma deficiência? Aí putz, vai ser pior ainda. É a realidade, é isso mesmo, vou tocando cara. Vou tocando e aí eu tô deixando o barco correr... Sei que talvez isso não fosse correto, tentar deixar pra lá, tentar dar uma esquecida, levar até onde dá e depois vai ter que procurar mesmo.

[O dia-a-dia é composto] De trabalho, graças a Deus, que é uma coisa que me motiva. Porque se você não tiver alguma motivação pro seu dia, você não levanta. Porque a cama tá mais gostosa no final da madrugada pro começo do dia, a gente sabe disso. Até mesmo porque a gente tá aqui nessa terra já faz um tempinho, e a gente já sabe que é bom, que não é. Você tem que ter uma motivação, eu tô buscando minha motivação em trabalhar. Ainda bem que tem o ATENDE aqui... Muitas vezes até, olha só, o ATENDE fica lá e eu ainda tô, fui lá pegar minha marmita lá na geladeira, o cara tá lá esperando, tem um prazo de cinco minutos, aquela correria, pá pá pá... Aí tenho essa motivação, motivação de ir, trabalhar, de convocar as pessoas, e depois saber lá no sistema, ou no final do mês, se colocou no mercado de trabalho. Então, você trabalhou direitinho, trabalhou mais ou menos certo, enviou o candidato mais ou menos certo, com o perfil da vaga. Então isso me motiva, é isso que ta me motivando e é isso que me segurou até agora no trabalho onde eu tô. De ter essa satisfação, poder ajudar alguém. Recusei algumas propostas aí, amigos que entraram junto comigo... Nossa, que legal, mas aí é que eu sou medroso, pé atrás, e ainda tenho esse outro lado, que é gostar de lá. 
Lá no começo, não cheguei a enxergar preconceito não. Mas assim, até mesmo uma compreensão dos colegas: "Ah, tá com dificuldade de integrar e tal... A gente sabe que sua oportunidade de estudo foi outra e não esquenta não... O sistema aqui é esse mesmo, então entra aqui, e fecha aquela tela ali e tal... Vai indo cara... Eu tô aqui do teu lado...". Então, tem muito de companheirismo. Isso não primeiro momento, de pessoas que não tinham deficiência e nada, uma empresa que não tinha; parece que eu fui um dos primeiros lá, naquele momento estava somente eu. E não teve superproteção, mas teve compreensão, então acho que isso já ajudou bastante.

Agora, na última empresa não, porque é pela AVAPE e, quando entrou, entrou no atacadão de pessoas com deficiência. Com deficiências mais severas, foi um número menor. Eu lembro que o processo de seleção foi até no cursinho da Poli, ali na Lapa. Porque era muita gente, quase cem pessoas entraram. E aí entraram três cadeirantes, falei: "Nossa, tudo isso de gente, só três cadeirantes? Mas pelo menos tem três né?". Porque tantos processos de seleção que eu fui que só tinha eu lá, de cadeirante. "Ah, mas você é deficiente?". "É, não tenho um dedo, eu tenho pé torto, só manco um pouco, aí me disseram que eu tenho, que eu me encaixo na lei de cotas... Tô aí, beleza...". Então assim, ou que sofreu algum acidente, tem faculdade, tem isso, tem o caramba. E eu lá no meio, só um cadeirante, a diferença é grande. Agora desde a primeira empresa, o que eu vi foi falta de acessibilidade...

Precisa contratar, precisa porque vai tomar multa e eu acho que tem que entrar o negócio da multa pra eles darem oportunidades... E é bem isso que eles falam hoje mesmo, que vaga tem, agora o que não tem, é pessoas qualificadas. Isso pra mim não é novidade não, eles tão certo sim, tem vaga de gerência de banco, já apareceu pra mim, mas se não tem cara [qualificação], então é uma real...

Então, falta de acessibilidade é uma coisa que sempre existiu; na primeira empresa, portas todas automáticas e queria ir no banheiro, era rapidinho. Mesmo a condição de ficar na cadeira, a bexiga fica pressionada e você tem que tomar líquido, pra você não ter infecção urinária, e tinha bebedouro alto. "Ah, mas nos já tivemos outros deficientes e eles se viravam... Ninguém nunca falou nada, não... Por que você fala?". "Porque eu sou chato... Bebedouro alto gente... A garrafinha lá, você viu que me molhou tudo..." E molhou mesmo, tomei um banho. Não teve jeito, esse dia do banho, lá vai eu lá, todo molhado. Tiveram que baixar... "Não, mas você não ta falando que você não vai ficar aqui pra sempre?". "Não, não vou mesmo, mas outros virão, pessoas com nanismo e tal...". "Eu não consigo não, cara..." (...) "Ah, mas eu já vi você subindo no braço da cadeira...". "É, mas não é sempre não que eu tô com pique".

Então tem que mudar, teve que mudar. O lugar que era pra eu trabalhar, o piso tinha dois degraus. Primeiro dia de trabalho, chega eu lá, aprovado, crachazinho, vai lá. Chegando lá, cartão magnético, a parte chata: fui entrando e dois degraus. Eu falei: "Hã!!!! Que que é isso gente?". Aí voltei, né. E já tava dando a hora, comecei a chamar o pessoal, aí foram ver:"Ah! Tem dois degraus! (...) Não, mas os amigos, colegas, companheirismo...". Companheirismo tá lá sempre, mas eu não aceitei e até saí de lá da empresa. Fiz uma carta pra gerencia: "Oh, tô saindo, tô insatisfeito por isso, demorou muito."

A saída da última empresa foi traumatizante. Até que foi indicado um remédio ansiolítico bravo, bravo que eu digo é tarja preta. Eu fui ver os farmacêuticos, parecia que tinha fogo na receita, ninguém queria segurar. E eu não sabia; o médico só falou assim, o neurologista: "Não, vou te dar um remedinho, você vai 
ficar mais calminho e é isso que ta te deixando com um monte de dor e... não se preocupa não, que vai dar tudo certo...". (...) Aí foi meio traumático essa saída e isso aí me deixou meio temeroso, com medo até de processo de seleção. Então, pra eu entrar nessa [emprego atual], eu fiz uns três processos de seleção e tomei pau.

(...) Aí pra eu entrar nessa, eu já tava assim, meio que parti pra um processo mental de que: "Vou tentar, vou tentar e se não consegui alguma coisa a mais, eu aprendo e tudo bem...". E consegui entrar e agarrei, e aí eu falei: "Não, tem que ficar pelo menos um ano, né? Porque até então... O mercado tá aceitando deficiente? Tá! Mas ficar com pula- pula... Não é legal, nem pra mim nem pros que virão". "

(...) Ficar sem fazer nada, o ócio é bom. Vir, ficar aqui em casa ouvindo música, rádio. Não tenho tanta facilidade pra ler. Eu gosto, mas assim eu tenho uma coisa de começar a ler e começar a dar sono. Embaralha tudo, aí depois tem que voltar naquela página de novo. Então assim, podia, já li, tento ler um pouco; mas livro mesmo, assim pegar não. Pego alguns textos, algumas coisas e leio, leio, leio. Eu saio, vou pra shopping. Eu gosto de natureza, de passear, mas até mesmo a própria condição não permite muito ir pra parque. Aqui o Vila Lobos é bonito pra caramba, mas nunca me atrevi a ir de ônibus; sempre com alguém de carro.

Os horários do ônibus [adaptado] são determinados pela empresa, a SPTrans. Então, por mais que a gente tente mudar, a gente não consegue muito não. É aquele horário lá... Por isso que entra essa questão de eu ter que acordar às quatro e meia da manhã, ou quatro horas, porque não consigo - pela minha ansiedade até - não consigo fazer várias coisas ao mesmo tempo e correndo. $\mathrm{E}$ eu tenho medo de queda... O punho eu machuco muito, porque tem que fazer transferência, pegar coisa, não sei o que, e com rapidez é pior ainda. Se você não tiver atenção... (...)

Então esse trajeto daqui da minha casa, até lá [ponto de ônibus], dá uns dez minutinhos, porque a calçada não ajuda. E aí, muitas vezes, tem que ir por asfalto e tem que ter atenção. Madrugada é pior ainda, porque vem o pessoal da balada e o cara já encosta ali pra ir na padaria com tudo, não liga pra sinalizar nada. Tem outra dificuldade também que é o pessoal que pega esses cachorros bravos pra passear, e eles soltam, imaginam que não tem ninguém na rua. Já aconteceu do motorista estar me puxando naquela rampinha do ônibus adaptado, e veio o cachorro e: Au!". (...) Fora a sujeira. Não sei se você reparou, eu tava com uma luva lá no trabalho. É tudo na minha mão, aí eu cuido muito disso; sou chato pra cozinhar, você não imagina como. (...) Eu tenho muito dessa coisa de higiene com a mão, preciso levar até álcool, lavar a mão, passa álcool pra mexer na comida, lava isso e deixa de molho aquilo.

Então tem essa coisa de sujeira de cachorro. O último episódio foi terrível, ainda bem que eu tava indo na camisaria. Porque eu fui passar e pá, não tinha visto; não pegou em mim, pegou na luva, porque pegou na roda; e aí eu fui mexer aqui no bolso pra pegar não sei o que, e sujou o bolso. Aí quando eu tava lá, conversando com a vendedora: "\Moço... Você tá com o bolso sujo. Será que foi barro? Sujeira? Terra?" A sorte é que eu já estava lá, já joguei aquela camisa fora. Então tem essa dificuldade, da sujeira nas ruas, porque as pessoas não cuidam da sujeira dos bichinhos. 
E nessa coisa de eu ir pra pegar ônibus, olho muito pra calçada. Tomei muita bronca por isso: "Mas você não lembra do endereço, cara? Do nome da rua?"." Não lembro... Eu só lembro que entra à esquerda, à direita...". "E porque não grava?". "Ah! Olho muito pro chão..." E olho mesmo, porque eu fico com medo de buraco, da cadeira parar e eu "buf". E já aconteceu... Já aconteceu, falta de atenção minha, porque tô no ponto, dando sinal pro ônibus e o ponto tá muito cheio e eu: "Ah! Com licença! Com licença!". Tô olhando pro ônibus, pra ver se o motorista me viu - que é o tal ônibus adaptado, se perder aquele, já viu - e acabei caindo e de cara. Sou que nem uma maria-mole, vai a cara, vai o rosto no chão, coloco a mão e tudo. Tem que ter atenção, não tem como. Então é a calçada que não é adaptada, é guia que não é rebaixada, e você atravessa e depois você chega lá tem dezessete centímetros pra você subir. Se eu tenho espaço para fazer, eu empino a cadeira e jogo. Empino, consigo subir empinado jogando e consigo descer empinado. Consegui aprender isso...

Eu aprendi sozinho, no gramado. Na grama, vai cair mesmo, mas não vai machucar tanto. E foi isso! O gramado prende mais, aí empino que é uma beleza. Mas assim, tem que ter atenção, porque é como andar de bicicleta: se você perder um eixo, você vai e não tem volta. E se eu perder o eixo, eu sei que não tem volta e aí é proteger a cabeça, a coluna. Porque de repente se bate, depois você pode ficar tetra, e aí a coisa fica pior. Mas, não faço pra me exibir; "Puta, Irado! É Irado!", a molecadinha fala. Mas se não souber... O monte de guia rebaixada que também, se eu não souber empinar, eu vou tomar um capote, eu vou cair mesmo, eu não vou conseguir e eu vou correr o risco de ser atropelado.

Isso ficou muito claro pra mim, quando eu saí com uma amiga cadeirante e ela não sabia empinar. Aí é que eu fui ver: "Caramba! Porque você anda devagar? Estamos na Paulista!". Foi antes da reforma, aí eu desci a primeira, tava esperando ela lá. Aí eu tinha que ir lá, puxar. Então é muito disso... É alguém falar: "Oh, vamos em tal lugar?", ou tenho a oportunidade de ir em tal lugar, e eu não conhecer o endereço, tenho que correr atrás e saber se é subida, se é descida ou até mesmo de ligar. Já falo logo: "Sou cadeirante, tá e tal...". E esses dias eu até recusei uma entrevista, porque era lá em Perdizes. (...) Porque quando ela falou: "Você tem fácil acesso?", eu falei: "Tenho...". Tem o Praça Ramos, pego o busão, tô lá na Francisco Matarazzo. Depois fui ver, aí liguei pra moça e falei "Não moça, não dá não, a ladeira aí, subida aí...". Então é assim, né? Aí eu falo que eu uso cadeira e o pessoal não se atenta pra isso.

Antes de eu entrar nessa oportunidade agora que eu tô, no CAT, eu tive que pagar taxi. Foi na Lapa mesmo! Numa empresa lá, me ligaram: "Oh uma oportunidade assim, assado... É um setor novo, você não vai fazer mais telemarketing...". Ela até me falou: "Tem uma estação de trem pertinho...". Fui aqui, me meti a ir em Osasco, e aí chega e não era adaptado o negócio e tem que pedir ajuda; os guardas ajudam até certo ponto porque eles não podem pegar lá na rua, porque foge do local de trabalho deles e não têm permissão. E foi isso que aconteceu. Falei: "Caramba! Pensei que parava no nível da rua!". "Essa empresa é aqui do outro lado, a gente vai ajudar você a subir, mas só que tem uma coisa: a passarela que tá de frente a empresa, a gente não pode descer você lá, porque aí foge do nosso local de trabalho... Mas dá tempo, oh se dá tempo! Você veio com uma antecedência monstruosa". Aí então eles me ajudaram a subir, chegou lá em cima lá e tal o cara foi lá pedir permissão e "Tudo bem, vocês podem ir", falou o chefão, "mas aí vocês deixam os equipamentos de segurança de vocês aqui e se acontecer alguma coisa aqui, vocês vão ser responsáveis, porque vocês estão abandonando o posto...". Você 
vê que tem gente boa, mas o desespero começou a bater e aí falei: "Ah, não! Um taxi, um taxi... Moço por quanto você me leva lá?". Peguei a bolsinha que fica em baixo, dei as moedas: "Putz! tem que dar!". E deu, mas eu já gastei vinte e cinco e, pra voltar, eu vou que pagar mais vinte e cinco; cinquentinha todo dia, até eu conseguir o ATENDE (que é no mínimo um mês, dois), é muita grana! Então, pra eu não perder essa entrevista, tive que pagar esse taxi. E tive que recusar, e é muito boa, na Lapa, na cara de casa, e por mais difícil que seja, mas é mais perto. Eu vejo muita dificuldade assim em me locomover mesmo, acho que se eu tivesse um transporte meu mesmo seria muito mais independente, mas daí sou bem consciente: "Se eu posso, eu posso! Se eu não posso,não posso!".

Agora, ficar na dependência de uma outra pessoa, não. "Ah, mas você trabalha, você podia financiar...". Mas, sou medroso, de repente perde o emprego. Tenho colegas hoje - não vou falar que é amigo - que tem carro, mas o carro tá com parcelas atrasadas. E por conta disso mesmo, desses calotes, é que muita coisa foi apertando pro nosso lado, da pessoa com deficiência, que falam: "Não... Não é tão assim, gente boa assim não...". E não é! Deficiência não é atestado de idoneidade. Não é porque é uma pessoa com deficiência, que tem um atestado de idoneidade, que é tudo anjinho. Se fosse anjinho, teria asa e não estaria aqui, estaria já voando por aí. Não é esse caso, não é atestado de idoneidade, nem a pau! Então assim, tem muito jeitinho, eu até vejo que quando eu tô, pendendo pra esse lado, eu saio fora.

A saúde falta mesmo, e eu tenho mesmo essa carência mesmo e sou chateado com isso, mas procuro não pensar. Eu já sou muito encanado, e se eu ficar mais ainda, aí eu não vivo. Então, deixa pra lá...

A minha passagem por aqui, na vida, é graças a minha mãe, senhora que no passado tinha filhos com parteiras (...) de falta de cuidados médicos, porque era difícil e tinha que viajar no meio do mato de cavalo, de madrugada. Minha mãe teve mais de dez filhos, de parto, agora, que ficaram vivos, até o ano passado, cinco. E desses cincos, ela bateu o pé e falou: "Não, esse não vai!" E meu pai, tão xucro: "Ah! Mas pra que tanto cuidado? Se não tem condição de viver, é a seleção natural...". "Mas se Deus quiser, vai ficar por aí...". E graças a Deus que uma, quis, e outra, que a minha mãe quis, foi atrás, não tinha condição. Meu irmão também não tinha, era menor, ela colocou meu irmão na frente: "Vai lá menino... Você vai lá em São Paulo, acha sua tia, e depois vem e me buscar e buscar seu irmão." E foi isso que ele fez e graças a força dela...

Naquele primeiro momento lá, eu brigava até com a humildade dela, por ver que as pessoas estavam brincando com a cara dela, aproveitando dela, e ela não reagia, ela falava: "Não, deixa pra lá filho, deixa pra lá!". E eu falei: "Não, mãe! Isso é preconceito, mãe...". "Não filho, não! Sou da roça mesmo, eu vim da roça... E graças a Deus, Deus me dá o que acha que eu mereço...". Então, ela partiu e sinto muito isso, tenho saudade, mas o que ficou, foi essa coisa daquele primeiro momento dela falar: "Não! Vamos buscar recurso, vamos ver... Não, esse não vai... Essa coisa desse: não vai...". Mas também a vida não proporcionou que a gente vivesse junto, eu sempre tive que viver em hospital, mas ela sentiu orgulho por isso, de falar que não e bancou isso.

É o que eu falo, a gente tá durando aqui. Acho que eu já tô fazendo hora extra por aqui. Graças a Deus que eu tô fazendo extra e incomodo muita gente. Queria passar despercebido, mas não dá, pela minha condição de cadeirante. E isso aí mexe muito comigo, eu queria ser mais na minha. Eu acho que quanto 
mais você quer fazer isso, mas você aparece, não tem jeito não. Você tem que pedir licença, pra você ir no banheiro, vai pegar ônibus, é aquela coisa toda. Então é uma coisa que eu tenho que lidar muito bem. Não é fácil, mas também pra mim, .se chegasse hoje e tivesse um milagre: "Oh! Você vai andar hoje", eu falaria: "Não! Não quero não, porque eu tenho medo, eu nunca passei por isso...".

Agora já passando da minha infância e, depois, quando eu tive que começar a buscar as coisas por mim mesmo, que eu me tornei mais fora da instituição, aí eu tive que correr por conta própria. Então, o que eu sentia é que muitas vezes eles não conseguiam enxergar: "Cadê o acompanhante?". Vê uma pessoa cadeirante, não só na área da saúde, mas em alguns setores falam: "Ah! Mas cadê seu acompanhante?. A princípio não apareciam muitos deficientes, acho que agora não sei, tô um pouquinho fora, mas acontecia disso, essa surpresa no primeiro momento. E depois eu comecei a freqüentar os postinhos e tudo, porque eu entrei no conselho regional de saúde, dos bairros. Aí eu comecei a me colocar, me impor: "Não, olha, eu sou cadeirante, tenho que passar na frente, tenho que ter prioridade...". E até mesmo de querer falar com o gerente do posto, pra questionar acessibilidade: "Ah! Não tem banheiro? Se eu tenho que ficar tanto tempo aqui esperando pra ser atendido, né...". Então foi um pouco surpresa pra eles.

[Para entrar no conselho] Foi a "precisão" mesmo: comecei a precisar. Não tinha meio de ter um plano de saúde, por conta de fazer o artesanato, então não tinha muito acesso. Então falei: "Poxa! E aí? E agora?". Aí comecei a me empenhar e entrar no movimento de pessoas com deficiência, do conselho municipal da pessoa com deficiência, que ali você tem vários contatos, eu comecei aqueles debates todos, e eu falei que o nosso segmento não tem tanta representação assim. Então eles também no conselho ficaram meio surpresos: "Não, ele é uma pessoa com deficiência... Então, olha que bom, venha, tal...". Faz, mais ou menos, uns sete anos.

Agora, eu dei uma parada da coisa do conselho, de freqüentar o conselho municipal de saúde. Por conta das reuniões do meio de semana; eu tô trabalhando, e reuniões à tarde no meio do expediente, não dá. não tem como eu bancar isso, então me afastei, perdi o pé das coisas. Comecei a pagar um plano de saúde, parei de ir no postinho; mas, em contra partida a gente esbarra muito nos benefícios que o Estado nos dá, porque eles querem laudos que são dados pelos postos do SUS. Inclusive, agora venceu a minha carteirinha de passageiro especial, que dá direito a viajar de um estado pro outro. E eu tenho que buscar um laudo, na UNIFESP, no setor de neurologia; aí também eu já perdi o contato, tô tentando buscar, mas aí é horário de trabalho. Então, isso tá vencido e vou ter que bancar a passagem por conta própria. E assim, os benefícios são poucos, e tem muitos entraves, tem muita burocracia.

Acho que uma coisa que vale a pena ressaltar, é a informação. Se o cidadão comum tivesse mais informação, saber que. tem o postinho, que tem o conselho, e buscar os seus direitos dentro da saúde, saber que caminho tomar. Tem aquela coisa de ter um posto de referência no bairro, aí a gente questionava muito na região oeste: "Não, mas olha, e o ônibus e transporte...". "Não, mas é lá porque lá tem um monte de profissionais e até tem fisioterapeutas e aqui a gente não tem...". O deficiente ficou meio rotulado que vai procurar só fisio, e não é. De um a forma geral a gente adoece e aí vai ter que procurar vários profissionais. 
[Sobre o movimento de pessoas com deficiência] Eu vou falar por mim: trouxe saber, conhecimento, saber o caminho a ser trilhado, não ficar vagando sem informação. Você tem mais contato lá dentro, você sabe quem é o coordenador de saúde, que cuida ali do bairro, você conhece o gerente do seu postinho, a assistente social do seu postinho, você sabe e então você tem acesso. Então isso aí me, abriu, lógico, o caminho de ver mesmo, de procurar as coisas, saber os caminhos certos. Agora como eu tô fora, eu perdi isso. Até mesmo a burocracia do SUS. Ele dá equipamento, mas você tem que saber qual o caminho que tem que ser feito.

Eu consigo fazer quase tudo sozinho. Estando na minha casa, a parte da limpeza, a minha higiene pessoal eu cuido eu mesmo; até mesmo questão de roupa, eu cuido, eu passo. não gosto muito, tenho dificuldade, lógico, mas eu posso fazer. Agora, o que eu não posso fazer é meio de locomoção. Aí eu vou precisar mesmo. Por enquanto, no estágio que eu me encontro hoje, como pessoa com deficiência, as minhas limitações são as minhas forças, e faz com que eu me vire bem no meu dia-a-dia. Eu consigo fazer transferência sozinho, consigo fazer a limpeza do meu banheiro sozinho, o meu quarto também, arrumar a cama, dobrar a roupa. Então, isso aí tudo bem, agora, quando passa a ter que ir em determinado local, aí tem que ver se precisa sim, se precisa de alguém pra levar.

Até mesmo quando tá doente. Quando você tá doente, você não tem forças, você tá meio down... Uma gripe, uma coisa assim... E aí eu tenho respaldo do pessoal lá da frente... Se eu tô muito ruim, o pessoal fala: "Então, tem que levar...". Aí leva no PS que eu tenho convênio. Já fui parar muito na USP, quando tava no conselho, pelas pessoas falarem, por conta da informação. Agora, essa questão mesmo de locomoção que pega mesmo. Aí eu vou precisar de ajuda. É a partir do momento que eu saio, eu tenho que pegar um ônibus, o ônibus não é adaptado, ou que seja adaptado, e aí vai...

Agora, as pessoas são muito solidárias, mas como pessoa com deficiência, eu tive que adquirir maturidade. Não é só a pessoa querer me ajudar, mas eu tenho que, naquele momento ali, fazer uma análise de risco. É uma coisa muito rápida. Então eu nego, e tô negando porque eu sei que tem risco. Eu sei que no reflexo, a primeira coisa que vai soltar, é os braços, é a mão. Então já teve esse problema aqui no trabalho, o elevador quebrar e os funcionários: "Não, a gente é solidário..."; aí eu falo: "Tudo bem, vocês são solidários,mas tem algum bombeiro aqui? Tem alguém que possa avaliar o risco? Que vai dar o aval? Não". Aí então, eu tive que ficar no meu andar, além do meu horário de trabalho, cinco horas, seis horas a mais, esperando que dessem um jeito. Então assim, fiquei muito medroso, tenho muito medo de me tornar um tetraplégico. Já fui empinar assim em casa, e mangueira, chão molhado: psiiuuu [som de escorregar]. Aí tinha uma senhorinha ajudando, fazendo limpeza, ainda bem que não tava sozinho; bati a coluna, que eu tenho escoliose e dá um pouco de medo, porque eu perco o movimento dos braços. Perdi na hora, aí eu falei: "Ih, Meu Deus!"; mas aí tomou um ar e voltou. Eu não sei se isso veio com a idade, ficar mais medroso... Eu fiquei muito mais medroso, avalio sim este tipo de risco. Muita gente não entende, na rua também não entende, no trabalho também não entende. Eu tenho medo; comigo não aconteceu, mas já aconteceu com amigo meu de não ter ônibus adaptado e a pessoa se oferecer pra ajudar, pegar ele no colo, só que o degrau estava escorregadio e, primeira coisa: quando a pessoa caiu, bateu as costas, foi soltar ele e ele machucou toda a parte da região glútea, então foi parar no hospital. A partir do momento em que eu aceite, então 
eu sou responsável, e eu passei a ser muito medroso. Aí muita gente não entende esse lado não... Acha que é orgulho e que não quer ser tocado.

Essa coisa de tocado é a minha cadeira, as pessoas não entendem muito: vem conversar, e aí coloca o pé na cadeira e vai colocando... Na hora que eu olho, já ta com o pé aqui encostado. Aí eu falo: "Não, não, não... É aí que eu ponho a mão, sabe? Eu sou nojentinho...". É a tendência, a pessoa vem, vai encostando o pé, vai escorando, na hora que vê... Eu sinto mesmo, que nesse momento a cadeira faz parte do meu corpo, aquela coisa estranha. Mas ao mesmo tempo quando eu passo numa vitrine, ou não lugar que tem espelho, eu não me reconheço. Estranho isso, eu não me reconheço numa cadeira de rodas. Muitas vezes eu vou me lembrar que eu uso a cadeira quando eu tenho algum obstáculo na minha frente. É engraçado isso! Não sei se isso é alguma coisa psicológica, algum bloqueio, deve ser... (...) Muitas vezes não me reconheço numa cadeira, mas ao mesmo tempo, se alguém tocar, eu me sinto incomodado. Incrível...

Daí eu vou puxar sardinha pro meu lado, mas é essa questão do direito de ir e vir. É o meio de acessibilidade, de buscar, de ir lá e de ter como chegar lá. (...) $\mathrm{Na}$ saúde passa por essa questão de ter nenhum transporte, o que está me incomodando muito hoje é a parte da educação e da saúde, que não tem essa coisa de ambulância. Isso aí de uma certa forma, prejudica, não faz com que a pessoa chegue lá. Então é essa coisa assim, de ter acesso mesmo, de um ir e vir aí.

Tem o ATENDE, mas só que o ATENDE, com essa coisa do direito de ir e vir, sobrecarregou o serviço. Então essa coisa de eu ter que trocar de endereço, que aí fica um mês ou dois até fora. Porque a educação não tem transporte, saúde não tem transporte. Então tem esse transporte que é oferecido. (...) Mas a gente tem que pensar na coisa da saúde, porque não tem muito eventual. 0 ATENDE não tem eventual, se eu preciso de uma consulta amanhã, não tem. Tem que ter uma programação sempre, e saúde não tem; precisou de uma ambulância, tem que ter um contato com uma assistente social, com alguém pra agilizar isso. Então acho que passa muito por essa questão do direito de ir e vir mesmo. É uma coisa que está muito latente em mim, é a minha dificuldade, então acho que eu passo essa dificuldade pro modo geral, acho que é isso...

E direito a informação. Acho que cidadão, não só a pessoa com deficiência, mas o cidadão em si... Se ele tiver a informação, ele sabe onde buscar, ele sabe que caminho tomar, ele não vai ficar vagando e achando que é injusto... 


\section{A história de Cristina - Sacrifício e fé...}

Descobri que eu tinha otosclerose com dezesseis anos. A gente sabia que meu vô tinha morrido surdo, mas não sabia o que era; meu pai também não ouvia bem, mas se dizia que era da revolução, que tinha estourado uma bomba no ouvido dele e ele tinha ficado surdo.

Eu tive meu primeiro emprego com dezesseis anos também. Eu trabalhava em um escritório de engenharia, era só eu e o engenheiro, e ele percebia que eu ficava pedindo muito pra ele repetir as coisas. Ele falou assim: "Cristina, você deve ter algum problema auditivo porque, sempre que eu falo com você, você fica pedindo pra eu repetir... Então era bom você consultar um otorrino". E, na época, na realidade, eu convivia com um barulho, pois eu tenho um zumbido que é característico dessa doença. Mas pra mim aquilo era assim...

E aí eu fui no médico, na época era SUS, não tinha nada; foi diagnosticado otosclerose, eu teria que operar os dois ouvidos. Primeiro eu operei um, eles tiram o estribo e colocam um de platina, era o pior; e depois eu operei o direito logo, acho que uns três meses depois. Mas, otosclerose é uma doença que falase progressiva...

Eu tomava também alguns remédios pra ajudar, pra parar o avanço da doença, e foi seguindo... Eu convivendo, porque mesmo com a cirurgia você não fica cem por cento bom. Uma porque ela já tava um pouco mais avançada; mesmo eu sendo nova, ela tava não estágio maior. Eu fiquei bem, pra mim tava bom aquilo... Eu sei que quando eu ficava um pouco nervosa, meu ouvido tinha lá os seus desgastes. Eu trabalhava... Com dezenove anos eu entrei no banco, trabalhava no Banespa, e aí segui minha vida assim...

Quando eu saí do banco - teve um PDV, o Banespa foi comprado pelo Santander - a gente passou uma pressão muito grande, e eu senti que meu ouvido caiu bastante; já não estava tão bom... Essa parte é difícil eu falar [...] E eu saí do banco num processo de PDV, eu tinha quarenta e dois anos...

E eu vi que minha audição tava muito ruim, muito ruim. O ouvido esquerdo eu já tinha operado uma segunda vez, porque eu tinha feito exame e a prótese tinha saído do lugar. Eu tinha ido no médico e ele falou: "Cristina, agora a cirurgia não dá mais pra você... Você tem que colocar um aparelho...". E foi muito custoso pra mim colocar esse aparelho. Eu sabia que eu ia ouvir melhor mas tem aquela coisa, besteira, a vergonha de assumir a deficiência, de ser surdo...

Eu acho que é difícil você nascer surdo e não ouvir, mas quem ouve e depois vai perdendo... Esse contato é ruim... E eu relutei bastante em colocar o aparelho: "Mas Cristina, é pequenininho, não tem problema...". É um aparelho bastante caro. Eu só coloquei também porque eu saí do banco, eu tinha uma grana e aí eu...

Em dezembro de $2001 \ldots$ Eu tenho indicação pra colocar nos dois e eu não coloquei, eu não consegui... Eu coloquei no que tá pior, que é o esquerdo... E você tem que fazer um exame, aquela bendita da audiometria, que pra mim é muito penoso fazer. Eu detesto fazer audiometria. É pra saber como é que vai ser o ajuste do aparelho. Você ouve um zumbido, e então o zumbido de lá confunde com o zumbido daqui... Você tem que prestar muita atenção pra ver 
qual que você ouve, o apito... A última audiometria que eu fiz já faz um tempo, e então é uma deficiência assim, meio profunda.

É ruim quando eu pego gripe porque... Eu digo que tem aquele filme meu pé esquerdo, então, tem aquele meu ouvido esquerdo... O ouvido fecha, não adianta aparelho, porque fecha... Fica uma semana assim, putz, ouvindo muito mal mesmo; fico muito ansiosa porque você tá aqui, tão chamando, tão falando e você... Eu costumo olhar e ler o lábio, mas se está longe, você não lê...

Eu até operei a miopia pra ficar mais fácil pra mim; porque eu tinha miopia, três graus, eu falei: "Se eu enxergar melhor, eu vou entender melhor...". Sabe aquela coisa? Tá longe, tá falando comigo, não tô te olhando, então posso ver você alguma coisa... Facilita mais! Eu operei miopia também com quarenta anos, com trinta oito por aí; eu tava no banco ainda. Então, assim, a gente tem que lidar com as deficiências; eu acho que é um pouco difícil, melhor é não pensar...

Em casa eu não fico usando muito aparelho porque quero forçar eu ouvir melhor. Mas não adianta, é uma coisa que ta lá... Aí eu vejo que quando eu boto o aparelho, eu ouço sons que eu não ouço sem... E aí você... [pausa, choro] É custoso falar... E aí você tem que ir lidando e, às vezes, parece que não está ficando bom... Eu penso só na possibilidade de ficar surda... Eu tenho medo, meu pai morreu surdo... É ruim pra mim...

Tem que ir no otorrino, mas eu não vou, saio fora...

Meus irmãos também operaram. Eu tenho dois irmãos também que operaram de otosclerose e também usam aparelho. Só que eles são mais velhos que eu. Mas assim, eu acho que eu tenho que seguir minha vida, eu tenho o que fazer, muito que trabalhar ainda. Eu confio em Deus que vai dar certo, que eu não vou ficar tão ruim...

Eu tenho que ficar fazer assim [movimento com a boca], sabe igual quando masca chiclete? Porque, às vezes, ele fica tampando e destampando, tampando e destampando... Então tá ruim... (...) Fora quando eu tô com gripe e às vezes quando a pessoa fala muito baixinho, pra mim é ruim; sabe, não adianta ficar conversando comigo baixinho; quando fica falando baixinho, falo: "Não, não... Me escreve, não fala comigo nessa hora porque eu não consigo...". Eu tenho que olhar pra você, prestar atenção e aí não dá; esse negócio de fofoquinha, baixinho, não dá pra mim... É uma coisa ruim pra mim. Tic-tac de relógio, essas coisas pequenas, eu não escuto...

Mas, o serviço é bom. Eu tinha medo de não ouvir quando mede pressão, mas escuto, porque você põe ele bem aqui, não tem como. Quando eu fazia estágio não tinha problema, e eu também trabalhei na UTI do HC, precisava estar... E os sons de UTI são altos... Então assim, no trabalho, no geral eu não tive dificuldade de me comunicar com as pessoas. Eu procuro, eu preciso levar uma vida normal. Eu só não quero ficar surda...

O aparelho é pequenininho, tem gente que vê... E às vezes: "Ah, Cristina, pensei que você tinha uma espinha...". Porque pra você puxar o aparelho, ele tem essa coisinha aqui. Ele é pequeno, pequenininho, tem até menores. Às vezes ele faz aquela microfonia. Eu vou estar trocando no final do ano, porque esse aqui já tem oito anos. É um aparelho caro, custa mais ou menos seis mil reais um aparelho desse; então, você tem também que ter condição porque é caro. Vamos ver, logo compro outro, mas eu não quero colocar um segundo aparelho. 
Todo dia é uma... São essas lutas silenciosas, que acho que todo mundo tem. Cada um tem, mesmo os perfeitos tem lá suas lutas. Eu acho que essa é minha lutinha particular...

(...) Eu divido a minha história de vida no período que eu trabalhei no banco, foram vinte e quatro anos. Então, eu amadureci muito lá e, era uma coisa que eu gostava de fazer. Quando eu tive que sair de lá, eu não tinha feito faculdade e hoje é uma coisa que se exige bastante. Às vezes, os cursos que eu fazia eu não conseguia terminar, porque como eu tinha cargo administrativo, eu tinha que ficar às vezes até tarde da noite trabalhando, eu ia perdendo aula e eu fui largando. Eu fui me dedicando, dedicando, dedicando... Porque eu achava que era aquilo que tinha que ser. Eu sempre fui assim, muito compromissada com meu trabalho. E aí, quando eu saí do banco, eu fiquei perdida mesmo, não fiquei em depressão, fiquei triste; não precisei de tomar remédio, nada, mas até eu fui numa terapeuta de florais, que foi legal pra mim, fiquei lá acho que uns três meses ou quatro, conversando com essa menina... E me ajudou bastante os florais. Essa coisa de cicatrizar uma ferida...

Porque, quando eu saí de lá, eu acabei perdendo a minha identidade. Tinha lá um círculo de pessoas, meus amigos, o teu círculo gira em torno daquilo. $O$ trabalho, as pessoas que convivem com você. Quando você sai de lá, essas pessoas continuam lá, mas elas já não te vêem mais como... Porque o dia a dia que junta, a convivência, são os problemas, as coisas que você vai enfrentando em conjunto com outras pessoas, você vai vencendo lá no trabalho. Isso que une! E aí eu saí... Eu até queria conversar, a gente se encontrava, mas eu já não me achava mais e falei: "Não tem nada a ver comigo, não é mais meu mundo né, eu tenho que procurar outra coisa pra mim...".

E, gozado, quando eu saí, eu falei assim: "Quem que eu sou né? Sou a Cristina... Mas o que eu vou fazer da minha vida agora?". Porque eu sempre pensei, uma vez eu ouvi um cara falando assim que, as pessoas lembram de você e falam de você por aquilo que você faz, não se você é bonitinha, é alta, magra... Mas é lembrado: "Sabe aquela a Cristina? Aquela que trabalha que fez isso, faz aquilo...". Aquilo que a gente constrói, não pela aparência... E aí eu pensava: "O que eu sou agora? Quem vai ser a Cristina?". Eu não sabia o que fazer. Pra mim não existia currículo, porque quando você manda, geralmente banco não pega outro de outro banco, porque já tem os vícios; principalmente porque era banco público, então é muito mal visto. Apesar de que a gente trabalhava... Eu sempre trabalhei muito, não tinha aquela coisa de encostar. Eu me negava a fazer um currículo. Foi muito, muito difícil pra mim, já com uma idade já mais avançada.

Eu saí do banco em 2001. Tinha quarenta e dois anos, aí eu falei assim: "Onde eu vou? O que eu vou fazer da minha vida?". Foi um pedaço ruim... Aí, uma amiga minha, que tinha saído também, falou: "Ah, Cristina, eu vou fazer um curso de enfermagem..." Eu falei: "Você sabe que era uma coisa boa. Faculdade não dá pra fazer porque eu não tenho grana e eu acho que eu não vou passar na faculdade pública...". Às vezes eu subestimo um pouco a minha capacidade... Falei: "Ah, mas o curso de enfermagem dá pra fazer, porque com o dinheiro que eu tenho eu vou segurando, pago o curso, vou fazendo concurso...". Porque é uma forma de você fazer; o mercado quer gente mais nova, mas o concurso público aceita você com a tua idade. Onde ela estava fazendo já não tinha mais vaga; ela começou antes que eu. As coisas sempre acontecem comigo assim... Eu tô no lugar, eu preciso daquilo, aí aparece... 
Eu sou batista, eu tenho uma fé muito grande em Deus, Ele que me guia apesar das coisas; eu acho que a gente não tem que ter uma vida mansa, a gente tem que ter a vida que a gente tem que ter, crescer, e Ele está junto ali ajudando, não é porque a gente tem que ter uma vida sem problemas. Acho que os problemas têm que existir mesmo pra você amadurecer, crescer, valorizar, saber lá na frente confortar o outro que ta passando por aquilo. São experiências de vida que eu acho que são muito importantes pra gente.

E, eu tava lá no metrô, desconsolada: "Preciso fazer um curso...". Eu não me conformava. Eu sempre trabalhei muito, e ali sem fazer nada, me sentia um lixo. Aí tava lá aquela propaganda de metrô: curso de técnico de enfermagem no SENAC, inscrições até... Hoje era sexta, amanhã, sábado. Disse: "Vou lá...". Tava cinco reais a inscrição; falei: "Nossa, é comigo mesmo...".

Fui no SENAC da Tiradentes. Eu queria fazer inscrição do curso e ela [atendente] falou: "Não, antes do curso tem que fazer uma prova... Tem que fazer prova, porque é muita gente; faz uma prova, a seleção vai ser amanhã...". Era no sábado lá... Era uma prova de conhecimentos gerais, depois uma entrevista. Eram quarenta vagas pra duzentos alunos... Falei: "Ah, tá bom...". Eu fiz a inscrição e, no outro dia, eu fui lá fazer a prova. Tudo bem, eu fiz, passei, e depois fui pra entrevista. Eu fiquei com medo na entrevista, porque eu fiquei pensando: "Puxa vida, tem gente... Eu vi as pessoas tão mais novas que eu... Quem será que eles querem colocar né? Qual vai ser o critério de corte?". Eu não sabia realmente qual que era o critério, e pra mim era idade. Era sempre aquilo... Aí deu certo, passei, e fiz o curso lá no SENAC...

Eles puxam bastante, tem que fazer muito trabalho, estudar muito... Eu achei que fosse mais simples, mas não é; eles exigem bastante de você, fazer trabalho com pesquisa, apresentava em auditório, fazia muita coisa, e os estágios são bastante rigorosos. Foi muito bom, foi uma coisa que eu aprendi bastante. Em março de dois mil e quatro, a gente terminou o curso, porque fazia o auxiliar de enfermagem e já entrava no técnico... Tinha gente que parava ali; falei: "Eu não vou parar, porque agora tá se exigindo o técnico... Eu já tô aqui, mais oito meses eu faço o técnico...".

E, durante o curso, eu ia fazendo concursos... (...) E eu ia fazendo, eu fiz todos os concursos... E me chamaram depois, porque eu passava, mas demorava. E foi bom ter demorado... Quando foi em março, eu acabei o curso e teve um concurso no HC. (...) Eu fiz o concurso, tinha não sei quantas... Tinham cinco mil pessoas, eu acho, pra noventa vagas. Nossa era muita gente! Muita, muita gente! Eu passei em terceiro lugar... A escolha era UTI, PS e o outro eu não sei. Eu falei: "PS eu não suporto, não consigo trabalhar no PS. Eu vou pra UTI...". Foi super penoso, foi muito difícil. As relações de trabalho são muito difíceis. O mais difícil é a relação no trabalho, porque se você não consegue trabalhar numa equipe, você não trabalha, porque você precisa do outro. Eles não tinham muita paciência em explicar. Parece que você chega lá, você já tem que saber. E você sabe muito pouco, na realidade. Quando você tá ali, na frente do paciente, aquela coisa pra você fazer, não é fácil; e ali era a UTI do grave, tudo muito sério... Meu Deus! Bastante difícil...

(...) Eu trabalhava à tarde, só que eu não gostava. Trabalhava da uma às sete, então eu tinha que sair de casa umas dez e pouco, pra comer alguma coisa, chegar lá, meio dia e meio estar trocada pra entrar no centro cirúrgico, pegar plantão. Isso eu chegava em casa quase oito horas da noite, mas até aí tudo bem... Eu fiquei oito meses lá, eu entrei em junho de dois mil e quatro. 
Eu ganhava uma miséria... Eu estava, sabe quando você já não tem mais dinheiro? E eu que me sustento, minha mãe mora comigo, e a vida que eu tinha quando eu trabalhava no banco era totalmente diferente, eu ganhava muito bem. Mas quanto a isso, eu me adapto muito bem, eu não me importo. Falei pra minha mãe: "A gente não passa fome...". Nunca tive problema nenhum com esse tipo de necessidade, meus irmãos também me ajudaram, mas também ninguém pode ficar te ajudando a vida toda. E eu cuido de bicho, cuido de gato, cachorro; a gente pega gato pra castrar, cachorro. É uma coisa... Nesse período, o meu maior medo era não ter dinheiro pra comprar as coisas pros bichos. Eu sei que não faltou dinheiro pra comprar comida pra esses bichos... Eu tenho umas gatas em casa que eu peguei na rua, cinco gatas, mas deu tudo certinho. Nossa....

Eu trabalhava pra caramba, eles não davam folga, engoliam a folga da gente, era um absurdo. Eu tinha uma folga uma vez por semana, trabalhava de sábado, domingo, feriado e dava uma folga na terça. Aí, ela [sobrinha] falou assim: "Cristina, é uma vaga só, mas você vai ganhar mil trezentos e cinqüenta...". Eu falei: "Nossa, o dobro!". Ela falou: "Cristina é muito bom, vai ser bom pra você, você precisa fazer esse concurso, estuda...". (...) Eu falei: "Puxa... Esse era o tipo de serviço que eu gostaria de fazer...". As meninas falavam: "Ah, que nada, trabalhar em posto é vacina, uma bobeira...". Eu falei: "Porque bobeira?". Eu não acho que é bobeira não, acho que a gente pode fazer um bom trabalho dependendo do lugar. Era uma coisa que ficava na minha cabeça, porque hospital eu acho muito sofrimento, eu sofro muito com o outro. Era muito difícil, ver a pessoa daquele jeito, e sempre morria um no meu plantão. A única coisa que eu fazia era segurar a mão dele... Era muito triste, muito duro lidar com essa morte solitária.

Eu fiquei lendo, eu não queria fazer inscrição... Eu sempre fico naquela: "Eu não vou passar...". (...) Falei: "Tá bom, vou lá fazer a inscrição...". Aí fiz a inscrição, mas não queria vir. Muito bem, aí fiz a prova, passei... Depois, eu fiquei sabendo que tinha entrevista, falei: "Meu Deus do céu, que raio de entrevista que é essa? Não vou passar... Não vai dar...". Eu fiz a entrevista. (...) Eu saí, falei assim: "Não dá nem pra você saber, fui bem, passei, não passei...". Eu pensava assim, deve ter alguma coisa que você diz que eles descartam ou não você; alguma palavra, alguma frase que você vai dizer, que vai colocar você lá ou não. Eu passei em segundo e era uma vaga. Então, não passei pra mim.

E aí calhou que eu trabalhava no HC da uma às sete, e eu tinha feito um concurso no Servidor Estadual e eles me chamaram. Eu tava precisando de dinheiro, o que eu tava ganhando não dava. Falei assim: "Eu vou lá, eu vou ver o que ganha e o que não ganha e aí eu vou trabalhar em dois... Não tem jeito...". Eu tava lá na educação continuada, já tinha registrado, tava fazendo treinamento, primeira semana... Aí o menino [do serviço atual] ligava pra mim, mas como minha mãe não tava em casa e eu ficava fora, não tinha ninguém. Calhou de um dia eu estar lá, não sei porque, e ligou: "Você tem tal dia pra assumir...". Eu falei: "Assumir? Eu não passei, eu passei em segundo...". "Não, mas já tão te chamando...". Eu falei assim: "Acho que eu não vou, eu já tô no meu segundo emprego, já tô na educação continuada...".

Olha só, eu não ia agüentar... Com essa idade trabalhar no $\mathrm{HC}$ e à noite, eu não ia agüentar... Minha irmã falava: "Mas você não vai ter força Cristina, você tem que andar tudo aquilo, lá em baixo, voltar, vai ficar uns dias sem dormir...". "Mas eu preciso ganhar dinheiro, eu não tenho como pagar as contas mais...". Mas aí, eu fiquei pensando, eu poderia pagar minhas contas sem me sacrificar. 
Eu ia trabalhar todo dia oito horas, não podia ter outro emprego. Eu falei assim: "Mas, eu já tenho dois garantidos. Vou sair de dois, pra ficar não só... E depois se não gostarem de mim eu vou ser mandada embora e ficar sem emprego nenhum, com essa idade eu não posso me arriscar...".

(...) Eu falei: "Ah não sei, vou pensar...". "Mas você tem que vir, eu não posso aceitar o seu não pelo telefone, você tem que vir e desistir da vaga pessoalmente...". (...) Aí ele falou uma coisa que eu pensei: "Você gostaria que outra pessoa que não eu, falasse com você? Você não ta sentindo firmeza em mim...". E eu tinha orado sempre, eu queria que alguém falasse pra mim: "Vem que é assim, assim...". (...) Daqui meia hora ligou: "É dos Recursos Humanos... Olha, Cristina, sou do posto...". Conversou bastante comigo. "Se você quiser vim aqui pra conhecer, eu mostro pra você o funcionamento, é muito legal trabalhar aqui...". Aí, ela falou assim pra mim, a última frase que ela falou, nunca esqueço: "Eu espero que Deus ilumine você, pra você fazer a melhor escolha...". É isso que eu queria. Era essa a resposta! Vou pedir demissão...

Aí no outro dia eu cheguei no HC, falei com a enfermeira lá, ela olhou pra mim e falou assim: "Cristina... É com dor no coração, mas eu acho que eu já sei o que você vai falar pra mim... Você ta pedindo demissão né?" Eu falei: "É, eu passei no concurso...". E ela conhecia aqui. E ela falou: "Ah Cristina, você vai ser muito feliz, você tem todo perfil pra trabalhar lá, você não conhece ainda, mas é um lugar...". (...) Eu tive que cumprir o aviso prévio, eles não me liberaram do aviso prévio e eu tinha que assumir aqui... (...)

E foi engraçado porque no dia que eu fui lá no $\mathrm{HC}$, era o último dia, eu tinha que assinar as coisas; eu tava trabalhando, e no horário do café, falaram: "Cristina, vem cá, que aconteceu um negócio...". Falei: "Ai meu Deus do céu... É algum rolo com alguma coisa que eu fiz, medicamento...". Nossa, quando eu cheguei, eles tinham feito uma festa, deram uma correntinha pra mim. Nossa uma graça! Você precisa ver, foi uma coisa... Porque eu tinha uns embates lá em relação ao jeito de cuidar dos pacientes; elas conversam muito e eu não gostava de conversar, eu gostava mais de ficar olhando ele [o paciente]. Eu falei: "Eu não tenho que poupar minha perna... Tô aqui pra trabalhar, as pessoas estão lá precisando... O mínimo que eu vou fazer é colocar uma aguinha lá com gaze na boca dele que tá seca... Se eu não tiver nada pra fazer...".

Aí vim pra cá, aqui é muito bom, eu sou muito feliz aqui, você sempre tem os relacionamentos são diferentes: o $\mathrm{HC}$ de um jeito, aqui é de um jeito e o banco também era de um jeito. Mas é uma forma de você estar crescendo, de você estar ali se questionando algumas atitudes suas...

Eu acho muito sofrido [trabalho de enfermagem]. Se eu fosse fazer faculdade, eu não faria enfermagem. Eu queria fazer biologia, eu tinha lá um sonho lá atrás: zootecnia. Eu gosto muito de gente. Eu acho que, enquanto eu estou aqui, eu preciso ter um compromisso com as pessoas, de tratar, de cuidar. E aqui é bom porque você conversa com as pessoas. Não gostaria de trabalhar na saúde mental, eu não consigo. Eu entro em sofrimento com o sofrimento dele, porque você não entra dentro dele, a pessoa tem aquela parede, ela vive em um mundo que a gente não consegue... E aquilo me deixa muito... Não dá, não gosto!

Eu gosto daqui, apesar de ser um trabalho meio louco. Acho que dá pra fazer um bom trabalho com as pessoas, ajudar. Cada dia é uma coisa, câncer... Eu acho que vale muito a pena trabalhar aqui. No HC também eu acho que foi bom pra mim, pra me abrir e no banco também foi. 
O que me tira do estresse é mexer com meus bichos. Eu gosto deles, cansa, mas é uma forma de aliviar...

Eu cuido da minha mãe, tem oitenta anos, já aí com demência e tá bem grave. Ela esquece o momento presente, ela não lembra, por exemplo, se ela comeu, se não comeu. É uma criança que você tem que dar banho, trocar fralda, arrumar, fazer tudo. O dia inteiro, aquela batida. Cansa bastante, mas bom que eu tenha feito enfermagem porque muito coisa eu uso lá em casa. São períodos difíceis, às vezes que você fica nervosa, tem um monte de coisa pra cuidar, pra arrumar. E às vezes a gente vai se largando.

Eu não sinto não [dificuldade no emprego por problema auditivo]. Não sinto, nem lembro... Às vezes eu acho que pelo problema auditivo, você procura ser um pouco mais... Não é mais, mas você fica mais assim na pessoa... Quando a pessoa está falando comigo, eu olho pra ela, ela é a razão ali naquele momento presente, ela é a minha razão. A escuta eu acho que é um pouco mais, tanto pra perceber como pra ouvir... São duas escutas... Não tenho dificuldade não, eu tinha medo do caso de não ouvir, essa coisa da pressão. Mas, passou, quanto a isso não tem problema nenhum. Não vejo nenhum problema, mesmo com gestante, funcionário, essas coisas...

Agora, quando eu tiro o aparelho, eu não escuto direito. O ruim é só quando eu tô com gripe, tomei injeção pra gripe. Eu não posso pegar gripe. Peguei gripe nas minhas férias, eu pego gripe todo ano, é uma coisa terrível, sou muito sensível. (...) Aí o aparelho não adianta, não faz efeito. Eu fico nervosa que eu não escuto, eu não quero falar com ninguém. Aí eu vejo o que é a deficiência auditiva!

E é gozado... Quando vem pessoas aqui que não ouvem, você se identifica, você tem mais cuidado. Você vê a deficiência, você sente o que o outro tá sentindo. Tem uma moça que vem fazer acupuntura, ela não fala quase nada, ela não ouve, ela balbucia, ela não sabe escrever. É bem difícil...

Foi gozado que ontem eu vi um programa da televisão, aquele Dr. Pet. E ontem, foi de uma cachorrinha, uma buldogue, coisa mais linda, cinco meses; e ela não atendia as coisas e achavam que a buldogue era rebelde, falava pra ela fazer, ela não fazia. Ela era surda! Eu acho que eu já sei, eu vi, eu falei: "Mãe, essa cachorra é surda... Ela não ouve as pessoas chamarem...". Ele fez os testes lá com fonoaudiólogos, com apitos, tudo... Ela ficava do mesmo jeitinho, a orelhinha não baixava, era surda. Eu vi que a moça ficou meio decepcionada com a cachorra. Ele falou assim: "Às vezes as deficiências...". Eu achei legal o que ele falou. "Você pode se comunicar muito mais do que se ela fosse normal...". Ele ensinou com luzes e ela aprendeu direitinho; aquilo que não podia era luz branca, aquilo que podia era luz vermelha, e quando ia brincar fazia assim e ela vinha, com o comprimento de mão. Uma coisinha mais linda! Ele fez algumas coisas de sinal com ela, mas tem que ter muito mais pra chamar a atenção dela. Ela vive no mundo dela. Eu falei: "É isso, a gente vive meio segregado assim...".

Eu acho que toda deficiência... É uma visão pessimista, mas acho que toda deficiência, de alguma forma ou de outra, ela te isola. Eu percebo nas coisas bobas, quando as pessoas estão conversando, falam muito rápido; às vezes as pessoas não repetem, porque não tão com vontade de repetir. $E$, às vezes, eu fico assim: eu não ouço naquele momento, eu fico pensando o que ela falou, aí aquela coisa vem... O ouvir depois... Eu tento fazer isso, para não ficar 
perguntando. Eu tento ficar pensando e fazer um retrocesso. (...) Eu faço essas coisas... Mas eu acho que a gente é meio segregado. É o mundo das pessoas surdas, é um outro mundo; existe esse mundo, ele é vivo, tudo... Mas é um mundo ali...

Eu atendi uma gestante, que o menino dela era surdo, zerado. Uma graça de menino, sete anos, muito fofinho. E ela falava com ele, aprendeu a linguagem e ele espertíssimo. E o menino dela, de cinco anos, se comunica com ele absurdamente bem na linguagem de sinais, precisa ver como a criança aprende rápido. Ela falou assim: "Olha, sabe que quando ele tá na escola, eu não sei quem que é surdo, porque esse daqui, ele parece que ele é também... Ele conversa com todo mundo numa rapidez...". Precisa ver que gracinha. Ela falou assim pra mim: "Olha, mesmo que tivesse a possibilidade de operar o meu filho, eu não operaria...". Eu fiquei pensando... Ela falou assim: "Não, Cristina é um outro mundo... Ele não morreu, é um mundo vivo, é o mundo dele, ele é feliz...".

Eu fico pensando: "Meu Deus, será que eu devo aprender essa linguagem de sinais?". Eu acho que seria interessante pra mim, no futuro... Eu acho que a gente fica meio diferente...

Ah, família... Nossa que dureza! Nós somos de uma família de cinco irmãos, quatro mulheres e um homem. Eu sou a última. Minha família é toda da Bahia, meus três irmãos mais velhos nasceram lá. Minha mãe ficou lá, meu pai veio pra cá, pra ver se acertava alguma coisa; depois de seis anos, ele foi buscá-la e a gente nasceu depois de dez. Eu e minha irmã que nascemos aqui, então a gente era mais juntinha e até hoje fica esse elo.

Meu pai trabalhava aqui em São Paulo de zelador. Papai era meio sem cabeça, ele era um homem bastante bonito e tiveram algumas complicações com o sexo feminino. Depois, quando eu tinha quinze anos ele se separou da minha mãe, foi embora. Papai não era mais zelador do prédio onde a gente morava, a gente morava num outro apartamento que a gente alugou. Com quatorze, quinze anos, que a gente foi pro outro apartamento, que já era alugado; quem bancava era meu irmão e minha outra irmã, que já trabalhava. Minha irmã começou a trabalhar com quatorze anos e eu comecei com dezesseis. Os três sustentavam a casa, trabalhava para o sustento...

Quando eu fui pro primeiro colegial, eu já comecei a trabalhar também; estudava à noite e trabalhava de dia, o dia inteiro... E aí o papai saiu de casa... [...] Foi uma história muito triste, porque meu pai depois ficou muito doente. (...) Ele veio pra cá, minha mãe cuidou do meu pai... Nós cuidamos dele doente, cuidava assim, acamado, papai morreu em casa... Muito triste...

(...) Eu tive três empregos na minha vida. Com dezesseis anos, eu trabalhei no escritório de Engenharia; depois, eu fui pra outro escritório de Engenharia, porque esse fechou e eu fui pra outro emprego lá no Bom Retiro mesmo. Eu estudava à noite. Depois, teve um concurso no banco. Eu tinha uns dezoito anos, passei no concurso, no Banespa e fui trabalhar... Trabalhei no Banespa por vinte e quatro anos. Aí a nossa vida já foi mudando...

Eu acho que minha vida foi difícil de infância, de pobreza... Minha mãe, apesar dela não ler, escrever, ela sempre ensinou para a gente alguns princípios. Então a gente não era assim essas meninas, bagunça... A gente ficava mais em casa, lia, gostava de ler, adorava ler. Na época Monteiro Lobato... Minhas irmãs 
compravam, a gente lia. Minha irmã trabalhava numa papelaria, ela pegava os livros, a gente lia e devolvia...

A gente morava em um prédio, quando o papai era zelador, eles eram muito duros com a gente; a gente tinha muitas vontades, você via algumas coisas que o outro comia, ninguém oferecia, ninguém dava. Mas tudo bem, isso passou. Uma parte foi bom pra mim, porque acho que ajudou a formar o caráter. Não fui nada, nem um pouco revoltava porque não tive, porque deixei de ter, porque meu pai foi embora. Eu acho que ficou um pouco da carência da figura paterna, daquela força.. Quando eu era mais nova, eu sentia falta dessa força...

Depois, quando eu fui pro banco, a gente teve uma outra vida, um pouco melhor, porque aí a gente ganhava bem, tava melhor. (...) A vida foi melhorando... Eu acho que o que eu tenho hoje, as dificuldades que eu passei, eu acho que elas foram necessárias, o problema de ouvido não me atrapalhou... Segui aí com a minha vida... Eu me acho vitoriosa...

Quando eu saí do banco, que teve o PDV - eu saí lá com quarenta e dois anos eu fiquei bastante triste, pensando o que fazer da vida. Pode não ser uma coisa muito grande pra quem vê de fora, vai falar: "Ah, você foi gerente de banco, agora você foi pra auxiliar de enfermagem, trabalha no hospital, ficava lavando os outros...". Trabalho menor... Mas eu não vejo assim, eu não vejo dessa forma... Eu acho que aonde eu estou, eu acho que eu tenho que fazer o melhor.

As pessoas costumam gostar de estar perto de quem tá lá em cima, aquela coisa do poder, que eu chamo de podres poderes. Você se empodera porque você tem um casaco branco, a gente se empodera porque tem o cabelo liso, uma barriguinha sarada. As pessoas se empoderam por coisas muito pequenas e não tratam do seu essencial mesmo. Eu sou evangélica, eu acho que tudo aquilo da minha vida que foi seguindo era pra ser assim mesmo, uma formação pra mim. E hoje, eu vejo assim: tudo que vem na minha frente, eu acho que o Senhor coloca pra trabalhar em mim e pra o que eu puder ajudar o outro...

Aqui é um lugar que eu amo trabalhar, porque dá você fazer bastante coisa. Dá pra você conversar com as pessoas, dá pra você dar um alento pra pessoa, não só em relação à parte física, mas um conselho, uma palavra, porque às vezes a pessoa vem meio desesperada... Uma vez uma moça falou pra mim: "Foi muito melhor aquilo que a gente conversou ali, na porta, do que você me mandar pra cirurgia... Eu não quero remédio, eu quero alguém...". Então dá pra você fazer, às vezes no meio um do outro, às vezes aquele que vai lá que você tá com mais tempo, você conversa. Tudo que chega a mão da gente, seja embolado ou não, dá pra você fazer. Eu quero fazer isso bem feito, não importa tudo que tá dando, essa pessoa precisa de mim. Pode até parecer meio demagogia da minha parte, mas não é... Eu vejo desse jeito.

Eu lembro sempre da minha mãe falando pra mim: "Trate as pessoas bem, porque as pessoas têm necessidades, assim como a gente teve, são pobres, são carentes...". E eu sempre ouço a Marina falando pra mim: "Dá pra fazer um bom trabalho na porta, eu sei que dá...". Eu vejo assim, não sei se eu estou floreando muito, mas eu procuro atender e conversar, ver outro pedaço. É um trabalho que me deixou muito feliz, eu acho que vale a pena, acho que eu sou muito abençoada. Eu ganho muito menos do que eu ganhava no meu serviço, mas tudo aquilo que eu queria fazer, que eu não fazia lá, eu faço aqui. 
(...) Eu fico pensando em mim em dois mil e um, em julho de dois mil e um, quando eu saí do banco... Nesses oito anos, tudo que aconteceu na minha vida... Foram coisas duras, eu tava pensando nesse fim de semana... Passei por grande escolha, às vezes humilhação - que eu acho que também são necessárias pra você baixar um pouco sua bola, às vezes você precisa descer um pouco pra você se equacionar no mundo - e eu achei que foi tudo muito certo pra mim. Foram esses oito anos de luta, de mais luta que vem pela frente, mas eu acho que eu não tenho do que reclamar. Eu tenho muito que agradecer... Eu não sei se eu virei a mesa, mas pra mim foi uma grande vitória.

(...) Às vezes é muito chato [a surdez na família]. Aquilo que eu falei pra você, às vezes a surdez dá uma separada. O meu irmão que tem sessenta, ele usa aparelho, o Romário. Eu não sei se por causa da idade, ele diz que ele não se adaptou muito bem ao aparelho; o aparelho faz um zumbido. Falei: "Ás vezes faz, mas porque ele tá mal ajustado...". Mas pra mim, eu me adaptei super bem ao aparelho...

E é ruim esse negócio da televisão muito alta. Quando eu tiro o aparelho eu não costumo ver TV, porque aí tem que aumentar muito. Eu gosto mais de ver filme legendado, então, fica baixo, porque eu também posso incomodar as outras pessoas. Eu não escuto, mas o outro ouve... Fica meio chato. Às vezes eu sei que meu irmão tá em casa, porque eu chego a TV tá na altura, e ele tem mania de não botar o aparelho. A outra minha irmã, a Eliane, ela tem sessenta e um, ela também usa, só que ela fez os dois ouvidos. É que a minha irmã ela já tem uma deficiência, ela é um pouco deprimida, ela tem epilepsia; então, ela tem várias, coisas que deixam ela mais caída. Ela que tem ficado em casa pela manhã pra cuidar da minha mãe, por que ela não pode ficar só. Às vezes, eu chego em casa pra cuidar das duas... Mas, tudo bem... E papai morreu surdo, quer dizer, surdo não, a gente tinha que falar bem perto. Papai morreu acho que com setenta e oito anos, por aí, então a gente tinha que falar bem perto dele. Meu vô, o pai do meu pai, também...

A primeira que foi no médico fui eu. Depois a gente foi conversando sobre os zumbidos - porque a otosclerose dá esse zumbido - e aí o meu irmão também foi, fez a cirurgia, minha irmã também fez nos dois, eu fiz três vezes... Mas a gente convive, dá pra conversar, a gente conversa normal, ninguém é surdo totalmente. Às vezes dá bronca, a minha irmã é muito distraída, eu já falo num tom mais assim, com a boca bem... Pra ver se ela lê, eu falo: "Eliane, pensa no que tô falando pra você, você ouviu...". Porque às vezes eu faço isso, a gente pensa: "Ah, a pessoa falou tal coisa...". Mas ela é distraída. É só você parar e prestar atenção. A gente que é deficiente, quando alguém fala com a gente, a gente tem que prestar atenção no que a pessoa fala, pra não cair nessa cilada do "Ah?... O quê?...". Isso é chato, ninguém gosta de ficar repetindo conversas... "Não fica assim ó... Olhando pro mundo ou pensando longe, quando alguém tá falando com você...". Quando alguém fala comigo, eu presto muita atenção na pessoa...

Depois que eu fiz a cirurgia, lá com dezesseis anos, e trabalhando, eu fui prestando mais atenção, fui ficando mais esperta. Mesmo na aula, na escola eu sentava lá na frente; eu sempre gostei de sentar na frente, mas eu sentava no gargarejo, ali na frente mesmo. Sempre prestei muita atenção... Uma vez, a mulher falou assim: "Nossa... Mas você fala com a gente olhando tanto pra gente...". Eu falei: "É assim mesmo... É que eu gosto de olhar pra pessoa...". Quando você não olha no olho é meio esquisito, eu não gosto de ninguém que fala comigo e não olha pra mim, olha no meu olho. Não só por você enxergar 
coisas diferentes na pessoa, eu acho que tem que ser assim, ninguém fala com ninguém olhando pra parede, pro vento, a não ser quem é muito tímido... Mas em casa, não tem grandes problemas não...

Eu não conheço mais ninguém assim da minha família que tenha [deficiência]. As minhas outras duas irmãs elas falam: "Ai, meu ouvido tá meio ruim...", mas ela ouve bem. Eu vejo que quando estamos em Vinhedo, você vê, ouve muito passarinho. Adoro passarinho! E ela falou assim: "Cristina... Você tá ouvindo esse... Eles fazem um piadinho assim bem, pi...pi...". Eu falei: "Rita... Esse eu não pego, nem com aparelho...". Mas talvez, se eu tivesse um segundo [aparelho], eu pegaria aquele som. Não pego... Às vezes isso eu sinto falta, não de ouvir pessoas, mas de ouvir a natureza... Eu gosto de ouvir barulhinho de passarinho, mas de resto não me atrapalha. Antigamente eu tinha medo, quando eu tava fazendo enfermagem, por causa do ouvido; tive medo quando eu fui fazer o exame médico pra entrar aqui, eu achei que eles podiam me barrar por causa da deficiência. Não perguntaram nada, mas eu falei que eu tinha deficiência auditiva, que usava aparelho, não atrapalhava e lá consta minha deficiência. Eu acho que a gente não pode mentir, não dá certo.

Eu não gostava quando eu ia medir a pressão: você tem que tirar o aparelho. Boto o óculos pra perto, pra enxergar a bendita pressão. Mas agora tem dois automáticos, que você põe no braço. Porque machuca, toda hora você põe aquilo no ouvido. Era meio chato, mas não é problema pra mim, eu escuto bem esse pedaço, porque o som aqui dentro, então não tem...

[Na família] Só óculos, mas todo mundo tem. Isso já nem é uma deficiência, hoje em dia. Você usar um óculos já não é uma deficiência...

Às vezes, eu acho que o mundo é feito pra quem não tem deficiência nenhuma. As coisas, o trabalho... Ou porque minha deficiência tenha vindo progressivamente, então eu não tô no mundo do surdo totalmente. Eu ouvia e agora ela tá caindo... Então, eu não conheço outro mundo, o mundo do silêncio. Mas, talvez, o preconceito esteja dentro de mim. Talvez seja isso...

Uma vez, eu tava aqui, e aí o otorrino que me operou, Dr. Carlos, eu o vi aqui, ele veio tomar vacina da gripe. Eu olhei pra ele e falei: "Não acredito... Dr. Carlos...". É lógico que ele não lembrou de mim, mas a gente conversou e ele falou pra mim que ele atende alguém daqui. Eu achei que era alguém, falei assim: "Ah, então, Dr. Carlos veio aqui, é você que vai lá?". Ela falou assim: "Não, ainda não tô assim... Não tô tão velho assim...". Mas eu também não sou velho... Não precisa ser velho, pra ser surdo... Ali eu vi o preconceito. Essa coisa do surdo, a gente sempre fala que velho é surdo.

Eu já não tenho o hábito de falar alto. A otosclerose é uma das surdezes que você fala baixo, porque você ouve muito... Eu não sei explicar, como é que ela funciona... Mas eu me ouço muito bem; eu tenho medo de falar alto, então, eu falo mais baixo. É uma surdez que você fala mais baixo, do que um surdo que grita, que não ouve. A gente ouve a gente... Às vezes eu tampo um ouvido pra ouvir a minha voz, é diferente. É diferente essa voz aqui que eu escuto da voz que tá indo pro aparelho. Você fala assim: "Ah, essa não sou eu, essa outra pessoa...".

Eu só fui no otorrino, fiz audiometria e viu lá que eu tinha otosclerose. E aí fui pra cirurgia, depois fiz a outra, mais nada. Com dezesseis num ouvido, com dezessete outro; depois com vinte e cinco anos, eu tive que refazer o ouvido 
esquerdo.

Eu teria que fazer as benditas das audiometrias a cada seis meses, detesto fazer. Quando eu fui lá fazer o aparelho, eles tem uma fono e elas fazem também [audiometria], apesar de eu levar a minha, eles ajustam o aparelho no computador. O resultado da audiometria foi lá uma perda severa profunda bilateral... Eu não gosto de ler isso, eu não gosto nem de ver o que está escrito lá. Dá uma sensação que tô mais surda se eu ficar olhando pra aquilo. Então não fiz nenhum tipo de acompanhamento.

Eu acho que seria legal um apoio, alguém pra conversar, pra falar sobre seus medos. Não é que você vai se curando, porque toda vez que eu falo dessa bendita surdez, eu fico meio entristecida, eu não gosto de falar não.... Mas eu acho que, se ela fosse trabalhada lá atrás, quando eu era mais nova, talvez hoje eu não chorasse. Eu acho que seria interessante uma terapia, uma conversa, alguém que fala com você sobre as coisas. Eu tive um otorrino muito legal - ele era do convênio, não era do SUS, quando eu tava no banco - ele conversava bastante comigo. Uma graça ele, só que aí depois acho que ficou muito rico, ele não atendia nem mais convênio, era só particular. Ele era um cara muito legal. A gente conversava, ele conversava muito comigo, um cara muito legal... Esse médico me deu bastante apoio... O Dr. Carlos [outro médico] era legal, mas ele era muito pá, pum, tá assim, tá assado; não há espaço pra conversa.

(...) Não fui mais, faz muito tempo que eu não vou no otorrino. Acho que eu preciso ir... [...] Porque parece que tem alguma coisa... Teria que tomar aquele bendito daquele fluoreto de sódio que ajuda a otosclerose não ir avante. $\mathrm{Na}$ época que eu tomei, eu tomei bastante tempo, mas eu passava muito mal do estômago, eu vivia vomitando. Eu era muito nervosa, lá atrás, quando eu era mais nova eu tinha muita gastrite, vomitava, passava mal. Agora o nervoso meu é enxaqueca. Mudou... Saiu de um órgão, foi pra outro... Mas até a Patrícia [colega de trabalho] tava falando pra mim que agora tá melhor, eles tão fazendo de um jeito que não ataca tanto o estômago, que seria interessante eu tomar. Preciso marcar um otorrino... Preciso ir, principalmente porque eu vou ter que trocar o aparelho... E aí tem que ter a bendita da audiometria...

É caro [o aparelho auditivo]. Hoje deve tá uns seis mil... Muito caro... Não dá... Eu comprei porque eu saí do banco, eu tinha condição de comprar. No SUS, tinha o CEMA, aquele hospital na Mooca. Ele tava com uma cota super grande de aparelho e não tinha procura; a gente foi espalhando, não só daqui, mas os outros lugares também: minha irmã, a Eliane, que não tinha condição foi lá e eles deram lá. Não são aparelhos assim, maravilhosos, mas pra quem precisa dá certo. Mas só que agora eles só tão atendendo a região; então eu, por exemplo, vou pra lá, eles não atendem. Só quem é da região, porque encheu de gente. Eu não sei mais nenhum outro lugar que disponibiliza aparelho. É muito caro! Hoje tá uns seis mil, seis e pouco. É caro! Quem vai botar dois...

Eu não tenho dinheiro, só vou comprar porque eu vou receber uma grana agora do banco, aí eu vou trocar. Porque ele também tá começando a pipocar; mesmo que eu não tivesse esse outro valor chegando, eu teria que me virar e pagar, porque eu preciso dele pra trabalhar.

Às vezes você precisa fazer manutenção, ele começa a dar umas apagadas. Tá com a pilha nova e ele não faz barulho nenhum, você não ouve como se tivesse sem pilha; e a manutenção é super cara, a manutenção é quinhentos reais. É muito caro. Essa pilha dura uma semana, custa doze reais quatro pilhas. (...) É caro e, no verão, ela vai embora mais cedo. O desgaste dela é maior na luz 
solar. Então, quando eu tô em casa, muitas vezes eu tiro o aparelho e deixo aberto pra economizar pilha. Todos esses detalhes... Tem que deixar ele bem guardadinho, arrumadinho; não dá pra dormir com ele. porque ele dá microfonia. Faz assim... Um sonzinho... Às vezes, alguém vai me beijar, bate aqui, faz pinnnn... Essas coisas são bem constrangedoras... Meio chatinho... Às vezes não me incomodo [que perguntem sobre o aparelho], porque de repente alguém precisa saber, a gente conversa. Mas, às vezes, eu fico constrangida com a deficiência. Acho que deve se bom você não precisar de aparelho...

Eu nunca esqueço o primeiro dia que eu botei esse aparelho. Estava no consultório da fonoaudióloga e ela estava com um computador ligado, e tem a ventoinha do computador, que eu não ouvia. Quando eu botei o aparelho, eu falei: "Que barulho é esse?". "Ah, é a ventoinha...". Eu não escuto sem; aí você vai pra rua, eu falei: "Nossa Senhora, que barulhão essa rua...". Com aparelho você não ouve ainda os cem por cento do que você ouviria; o ouvido já tem uma deficiência, não adianta lá um ouvido deficiente você botar uma coisa, ele não vai ser nunca cem por cento. Tem um limite, do quanto tá atingido lá. Eu fico imaginando quem ouve bem, deve ouvir uma barbaridade, os dois ouvidos, sem barulho, deve ser uma delícia.

Fora o aparelho, você tem que lidar com esse zumbido do ouvido. Tem um zumbido aqui direto. Se eu ficar prestando atenção nele, incomoda. À noite, pra dormir, eu sempre tô com muito sono, eu durmo mas, às vezes, fica aquilo. É chato, mas tem que conviver... Faz parte do processo... Eu vejo, por exemplo, pessoas que vem aqui, falam assim pra mim: "Nossa, de repente apareceu um zumbido... Eu tô ficando louco com esse zumbido...". E o zumbido, às vezes, acontece não só por causa da otosclerose, outras coisas que podem [causar]. E eu vejo que as pessoas ficam alucinadas; deve ser muito ruim mesmo, quem tá tudo bem e de repente começa um zumbido na cabeça. Todo mundo quer uma coisa que tira o zumbido, ninguém quer o zumbido...

Seria muito bom se eu não precisasse ter o bendito do aparelho. Mas de resto... Eu sei que vai ficar assim; quer dizer, pode até piorar, mas eu creio em Deus que ele não vai piorar. Que vai estabilizar essa coisa. Eu ouvindo assim pra mim tá bom, não preciso de mais não...

Eu não vou a nenhum médico. Não tem nada fora os habituais, mamografia, as coisas de mulher. Só isso... Não faço nenhum outro tipo de acompanhamento, eu não tenho nada de saúde. Graças a Deus, tô bem... Eu pago convênio, eu tenho medo do SUS! Não é medo do SUS, mas eu acho que esperar muito não dá. (...) Da minha mãe [o convênio], pagamos os quatro irmãos, mas é caro: eu pago quatrocentos reais de convênio por mês, por causa da idade dela.

Tem uma coisa também, ele [o aparelho auditivo] vai se alargando, parece que vai ficando meio solto. Daí dá esse tuuuuu... Essa microfonia. Eu sei que tá na hora de trocar mas, daqui a pouco eu troco, eu vou comprar o menorzinho. Diz que é mais potente, aí eu vou ver. Vai fazer oito anos [que colocou o aparelho]. Eu botei em setembro de dois mil e um, quando eu saí do banco. O médico falou pra mim que numa situação de muito estresse ela pode acelerar. Eu fiquei muito mal, eu não tava ouvindo nada. O Dr. Vieira já tinha falado pra mim: "Cristina, você precisa botar um aparelho...". Eu chorava, falava: "Não vou colocar...". "É pequenininho Cristina, ninguém vai olhar, vai ser bom pra você... Você vai se sentir melhor... Mascara o barulho...", isso que ele falou. 
(...) Eu acho que a experiência de vida conta quando você vai conversar com as pessoas. Quando você passa por alguma coisa, quando você vai falar com a pessoa você sabe o caminho, o que ela pode estar passando. Não é que eu compreendo, nem é que eu tenho compaixão dela, mas eu consigo entendê-la e trocar uma idéia, conversar com ela, pelo menos falar que esse pedaço também vai passar e as coisas vão melhorar. Isso aí é muito importante, você ter alguém quando está passando por um problema muito grande. É bom você às vezes ter um amigo, alguém que você possa contar; você pode falar... Você vai passar, porque você precisa passar, é o seu pedaço, mas você tem que saber que, por exemplo, eu já passei e a gente cresce nessa passagem. E depois você pode contar pra outro, você pode ajudar o outro, e é uma corrente.

Eu nunca esqueço de um menino que trabalhava comigo lá no banco, ele tinha feito direito lá na São Francisco, um menino super novo, e um amigo dele também fez direito, e na época que ele fazia direito lá na São Francisco, ele estudava pra concurso, porque ele queria ser juiz. E é super difícil concurso de juiz. Quando ele passou, com vinte e quatro anos pra juiz, eles não quiseram que ele passasse porque ele não tinha experiência de vida na hora do julgamento. Ele não ia saber... A pessoa tá lá com cinqüenta, trinta anos, que experiência de vida esse menino...

(...) Eu acho que é muito importante isso que a gente passa, e passar pro outro, ajudar o outro. Mesmo quando as mulheres chegam e falam: "Ai, porque eu tô assim... Porque aconteceu isso...". Porque as mulheres são muito levadas nessa parte sentimental. Nas minhas experiências eu não preciso falar: "Olha, escuta...". Essa é mais ou menos a historinha; você precisa barrar essa historinha e fazer essa historinha mudar. É você que vai mudar a sua história de vida, não é outro. Não entregue a sua vida na mão de um homem, o seu destino... Uma vez foi engraçado, falei com uma moça, conversei bastante com ela, e ela falou assim: "Você é vidente? Você tá me falando tudo da minha vida...". São as experiências de vida são parecidas e eu sou mulher, posso ter passado as mesmas coisas, de um jeito ou de outro. E a gente vai vendo o que acontece com os outros, o jeito da mulher, o jeito do homem, você vai tendo as experiências...

(...) A mulher, a reação da mulher é chorar, se descabelar e falar: "Ai, o que eu fiz de errado?". O homem, ele faz assim, vira a página e amanhã é outra vida. É isso que o homem faz, homem não se descabela, não chora; daqui uma semana tá com outra, a cabeça dele é outra. E a gente fica lá naquele sofrimento. (...) É aquela coisa, você luta e pega aquela suposta derrota e vira como uma vitória, como outro relacionamento. Ser diferente, pensar diferente, eu acho que ajuda bastante.

Eu falo assim, às vezes pra um pouco me consolar porque eu acho que eu fiquei meio torta: não ter feito uma faculdade. Isso me incomoda. Às vezes me diminuía, agora não me diminui mais. Eu acho que lá atrás, se eu tivesse pensado melhor, eu teria me dado bem, porque eu gosto de estudar, gosto das coisas, eu acho que eu me comprometo muito com aquilo que eu pego pra mim. Queria fazer outras coisas... Eu não tenho inteligência acadêmica, mas eu tenho inteligência prática, eu tenho umas qualidades... A gente tem que ir tampando as coisas, se não você fica sempre no perdido, fica sempre se lamentando. Você fez lá suas escolhas, eu fiz as minhas escolhas, não deu certo, mas eu fiz outra... Se eu for ficar sentada chorando no meio do caminho, eu não vou fazer nada. Então, tem que ir pra frente... 
(...) Eu acho que o homem ele é mais fechado no problema dele. Eu acho que ele fala menos, porque eu vejo meu irmão: ele fala comigo, porque a gente tem uma deficiência, mas às vezes ele não gosta de falar. Eu vejo que aquilo é um sofrimento mesmo pra ele. Ele fala assim pra mim: "Ai, Cristina, tô tão ruim... Tô piorando...". Na família dele também, ele é casado, tem dois filhos, eles não tem muita paciência com ele. Eu falei: "Romário, põe o aparelho Romário... Não fica sem o aparelho...". E aí, a mulher dele parece falar bem baixinho, só pra ele não ouvir. Eu acho que ele fica meio perdido. Ele trabalhava na GM [montadora de automóveis], era mecânico; lá era um barulho desgraçado, ele tinha que botar aquela coisa que tampa, que já dá microfonia, ele com aparelho. Ele falou: "Cristina, eu fico louco, porque eu ponho aquilo... Aí eu opto em botar o aparelho no bolso e tacar aquele negócio que eu não posso ficar sem...". Agora ele já saiu da GM, aposentou, mas, eu acho que ele sofre.

Hoje eu vejo que, quando eu falo sobre isso, é melhor pra mim. Porque você vai tirando fora essa coisa... É mesma coisa quando se fala assim: "Ah, não adianta nada, o problema é meu, eu vou resolver...", mas se você tem um amigo pra compartilhar, ele não vai resolver o problema, mas ele vai te ouvir. Tem que ser a pessoa certa, que realmente ouça você; você tem que sentir que a pessoa tá ouvindo você e se interessando pelo seu problema. É a mesma coisa aqui [no trabalho como profissional de saúde]. Essas pessoas vêem que aquilo é importante pra elas, você é o objeto lá de interesse dela, da atenção. Então, acho que um amigo funciona assim, porque ele se preocupa com você, ele ouve, às vezes ele pode falar uma coisa pra você que você dentro daquele problema não consegue ver. Ou não fala nada, mas você conseguiu tirar um pouco dessa angústia que fica dentro da gente.

Às vezes a gente fica meio angustiada, não tem com quem falar, não tem um amigo; tem que ter alguém, a não ser que seja muito bem resolvida na vida, não precisa de nada. Mas acho que, em algum tempo na vida da gente, você tem lá umas coisas. Eu falo com a minha sobrinha que é ótima, tem trinta anos, a gente conversa muito. Eu falo com a minha irmã, eu falo com os meus irmãos, eu falo com algumas pessoas que você tem uma amizade melhor e aquilo vai te aliviando. Às vezes elas podem te ajudar de alguma forma, te dar um lamento, mostrar um caminho diferente...

Quando eu tava no banco mesmo, eu fazia terapia com uma psicóloga. A minha amiga falava: "Vai que você tá precisando, que não sei o que...". Eu falei assim: "Mas, o que ela vai falar pra mim? Ela vai resolver meu problema?". "Não, mas ela vai conversar...". Acho que eu fui umas quatro sessões, eu não gostei. Quando eu saí do banco, eu fiz a terapia de florais, aí eu gostei. Eu fiz uns seis meses, também era muito caro, mas foi bom pra mim. (...) Os florais deram certo pra mim, tiraram aquela coisa do banco, eu chorava, chorava... Eu perdi minha identidade... Aquele sofrimento ruim, tô me matando. E sem perspectiva, porque eu não sabia o que eu ia fazer da vida; me achava vagabunda, porque eu acordava de manhã: "Pra onde eu vou?". (...) Então, eu acho que a gente tem que ter alguém pra conversar.

Acho que funciona bastante aqui, aquela porta [porta de entrada para as consultas]. Às vezes, ela tem bastante terapia. E eu acho legal a gente fazer isso, porque eu fico pensando: "Poxa, eles não tem nada... Âs vezes tem tão pouco pra onde ir...". Porque que a gente ali não pode fazer alguma coisa? Mesmo eles [os usuários do serviço] brigando, xingando, eu não ligo. Eles falam que a gente demora muito; eu sempre costumo, lá na porta, eu levanto e vou lá chamar; falo bom dia, abraço a pessoa, eu nunca sei chamar sentada. Eu gosto 
de ir lá e, quando a gente vai lá, você conversa com a sala [de espera]. "Quando você entrar lá, você não vai pensar no outro que tá aqui te esperando, você vai falar sua queixa, as suas queixas...". (...) Você vê que a pessoa tá meio assim, aí você fala, acaba sendo um consultório ali, não é terapia, mas consegue levar bastante coisa. Uma coisa muito legal que eu não vejo em lugar nenhum... Se todo mundo trabalhasse assim... Todo mundo aqui tem um compromisso...

(...) É difícil [cuidar da mãe], principalmente porque o problema dela é neurológico, então ela não sabe o que ela fez, não sabe o que tá fazendo. Às vezes, você fica meio sem paciência, apesar dela ser minha mãe. Tem dias que ela tá melhor, mas tem dias que ela faz umas artes. Ela tem uma coisa com comida... Ontem eu demorei pra fazer a comida, porque eu tava limpando o banheiro, teve pedreiro em casa esse fim de semana, e eu via que ela tava na cozinha, tava lá com as panelas com o arroz dentro. Ela não pode o fogo ligado, essas coisas. Ela não tem noção, não tem mais noção nenhuma. É difícil, você tem que ter bastante paciência, muita paciência, porque ela pergunta - não porque ela é surda - a mesma coisa várias vezes; e ela esquece, aí a gente fala de novo, aí repete outra vez. (...) Às vezes, você quer conversar com ela, como se fosse alguém normal. É disso que eu sinto falta, da minha mãe. Ela era dessas baianas bem agitadas, fazia tudo, brincalhona e, de repente minha mãe murchou, ela pouco conversa, ela não quer sair. (...) Enquanto eu estou aqui, tem outra irmã minha com ela, mas essa outra irmã não tem o despacho de fazer comida, de fazer as coisas; então, eu tenho que deixar tudo organizado, nenhuma vírgula fora do lugar.

Tenho uma cachorra, eu tenho cinco gatos, então quando eu saio de casa... Por isso que eu acordo muito cedo, eu acordo quatro e meia pra sair de casa às seis. Eu deixo tudo assim, programado: o almoço, o café, o comprimido, a fruta, tudo bonitinho pra ela, tudo pronto. (...) Quando eu chego também, não dá tempo, eu já chego trabalhando, já começo arrumar uma coisa, limpar a casa, tem que ir no mercado, tem que fazer comida no outro dia. Então essa luta... Mas a gente reveza, tem outra irmã minha que mora em Vinhedo, ela fica um pouco lá; como ela tá com problema, já tem um tempo que minha mãe tá aqui. Cansa, cansa... Eu fico bastante cansada...

(...) Ela [a mãe] não pode ficar sozinha, ela não consegue. A gente que tem que dar banho nela, ela perdeu a noção do limpo e do sujo; ela vai no banheiro, eu tenho que ir junto com ela, eu que tenho que dar o papel pra ela se limpar, botar fralda. É mais que um bebê... (...) Você tem que ir forçando as coisas; mas, é difícil, é bem cansativo. (...) Ainda bem que a minha sobrinha mora no nono e eu moro no quinto... (...) E também você tem que sair, levar, nossa... Aí você vai dormir onze horas da noite, no outro dia acorda, e aí você tem que conciliar, estar bem aqui com estar bem em casa, você não pode não ficar bem. E tem hora que você não fica bem né?...

Eu aproveito quando ela dorme um pouco, eu saio com a cachorra; vinte minutos pra andar, é o meu tempo. E é bom pra mim, faz bem. Esses dias eu não tenho saído com a cachorra, eu tenho sentido falta, e ela também, porque ela é grandinha. Mas é bom pra mim, pelo menos eu ando; parece que você está, não fugindo, mas espairece um pouco. Mas é cansativo. Mas, não tem jeito. Tem que cuidar, cuidar bem... (...) Eu não tenho coragem de botar ninguém pra cuidar da minha mãe, não tenho. Se for alguém que não é confiança, não dá, ela não vai lembrar, ela não vai falar. E é muito constrangedor essa coisa de ir no banheiro, tem que se limpar; minha mãe não merece passar por isso, então tem os filhos, as filhas têm que cuidar dela. Eu 
acho que é isso que tem que ser, nem que a gente se esforce mais. Eu não tenho coragem de botar ninguém em casa pra cuidar da minha mãe; enquanto a gente puder, a gente cuida. Acho mais correto.

Às vezes, ela fica brava assim, porque eu falo: "Mãe, isso não é assim, mãe... A senhora já viu... Tá errado...". Ela fala: "Você não precisa falar alto, a surda é você...". Ela manda... A Dona Carmela, não é brincadeira... "Eu falei mãe... Mais eu já falei pra senhora, a senhora não pode fazer assim mãe...". "Mas, menina... Antes você falava mais baixo, agora você tá gritando...". "É que eu vou ficando nervosa mãe... Porque a senhora tá fazendo errado...". Essa coisa de se limpar, é muito penoso, meu Deus! Não é fácil!

(...) Com a outra minha irmã, ela não atende; a Roberta não tem mais muita força com ela. E acho que é porque eu sempre morei com a minha mãe; eu sou solteira, então a gente morou junto, eu acho que ela tem mais referência em relação a mim. Às vezes ela briga comigo: "Não, não vou...". Falei: "Vai... Comigo mãe, não tem escapatória, vamo tomar banho...". Não tem perdão, não deixo ela sem tomar banho...

(...) Eu morava na Saúde e há um ano e meio eu tô nesse apartamento nas Perdizes, que é perto da casa da minha irmã. Pra mim, foi uma coisa muito boa morar, mudar pra cá; pra minha mãe, quando ela tava um pouco mais lúcida, foi muito penoso. Ela não quis, ela achava que tudo lá era ruim e ela foi ficando ruim. Tem um ano e meio que ela tá assim. Tudo pra ela, é ruim, ruim, ruim.

A gente uma vez foi lá [no antigo apartamento] e mostrou o apartamento; ela falou: "Eu nunca morei aqui...". Ela não lembra lá da Saúde. Melhor ela até ter esquecido isso, mas ela não esqueceu dos filhos. Esquece assim, se alguém vai lá, conversa e depois vai embora, ela fala: "Ah, fulano faz tempo que não vem...". "Não mãe, o Romário veio aqui...", porque ela tinha um agarramento com meu irmão. São quatro mulheres e um homem, ela sempre falava: "Cadê Romário? Cadê Romário?". E aí quando ele não ia, ela falava, mas agora ela não tem falado também, não tem sentido a falta. Um dia ela falou pra mim assim: "Olha como é que eu fiquei... Eu não sinto mais saudades...". Ela teve essa percepção; ela falou assim: "Eu não sei o que é saudade...". Ela até chorou... "As pessoas vem aqui, conversam comigo, tudo, depois vão embora... Pra mim, se elas não vêm ou deixam de vim... Eu não sei mais o que é isso...".

(...) Ela gosta de ficar vendo TV, vê um programa da igreja que ela gosta. A fé dela ela não perdeu. Isso é muito importante pra ela, isso ela não perdeu. Eu acho importante também. Você pode me esquecer, mas não esquece Dele, que pra gente é importante. (...) Parece que, nesse tempo, a nossa vida tá se resumindo ao redor dela; fica tudo meio ao redor da mãe: o que eu vou fazer, como é que eu vou me encaixar, quem vai ficar, como vai ficar, fazer isso pra minha mãe, levar minha mãe... Então você fica meio de lado... Eu não me incomodo...

Nesse cuidado, às vezes me canso. Cansar acho que é normal, porque a mente fica cansada, o físico cansa. (...) Mas eu não posso interferir lá com o meu trabalho aqui, não é justo. Não é correto também, mas eu levo bem. Mesmo estando enrolada, preocupada, eu consigo porque, quando você tá aqui, o outro precisa de cuidado. Agora eu vou ficar falando: "Ah, não que tô assim nervosa porque..."? Não, não é justo, não é correto. Eu não tenho esse problema não; posso ficar meio assim com os daqui [colegas de trabalho], falo menos, fico mais calada, preocupada, mas com atendimento eu vou normal. É a ética... 
(...) Minha irmã tem essa casa em Vinhedo. (...) É lugar muito bom, muito bonito, uma delícia; por mim, eu ficaria lá e não voltaria mais pra São Paulo. E eu ia muito pra Vinhedo na época que a minha mãe tava bem. Eu tinha uma outra cachorrinha, a minha mãe ficava lá com a minha irmã, levava a cachorra e eu trabalhava e ia nos fim de semana. Ia no sábado de manhã e voltava no domingo de tarde. Era uma coisa muito boa pra mim. Não fui mais pra lá. Vou muito pouco, nas minhas férias eu fui um dia; fui de manhã e voltei de tarde, não consegui, não deu certo minha mãe ficar lá e minha irmã também tava com problema. Eu não consegui muito descansar.

Lazer... Que lazer que eu tenho? Fora andar com a cachorra, às vezes eu assisto um filme, de noitinha... Ler alguma coisa, muito pouco, não consigo... Tenho livro pra ler e não consigo ler. $\mathrm{E}$, às vezes, quando minha mãe não está aí, eu saio por conta minha. Vou pro um lugar sem destino... Eu adoro fazer isso; acho que é o saber que eu posso sair de casa, fechar a porta e andar; nem que seja no bairro. Tem bastante coisa. Eu gosto de ir livraria, adoro ir naquela Livraria Cultura ficar vendo livro, adoro... Tomar um café sem a minha preocupação do que tá lá em casa. Porque mesmo que eu saia, minha irmã fica em casa: "Ah não, vou ficar pra você ir em tal lugar...", mas pra mim não adianta, porque alguém tá ficando pra mim. A outra tem que fazer alguma coisa, e eu tô passeando. Não consigo... Eu acho que não é justo, eu estar passeando enquanto o outro está trabalhando. Eu vou no shopping, saio com a minha sobrinha, ou a gente vai comer uma pizza, coisas familiares, porque eu não tenho ninguém, eu não namoro. Então, fica mais ou menos restrito, mas eu não me incomodo disso. Eu acho que faz falta mesmo assim: eu ter um tempo pra mim.

Hoje, o dia inteiro, eu tenho tempo pra mim, mas eu não tenho esse período em casa. Você já chega trabalhando; às vezes eu pego a bolsa boto na cadeira, nem vou no banheiro. Tem isso, tem aquilo... Tem minha mãe que, às vezes, não tomou banho com a minha irmã... Eu nem almoço; depois que arrumei tudo, aí eu vou comer, lá pelas cinco. Gostaria de ter um tempo, mas não tá dando...

(...) A gente reveza assim: uma [irmã] fica uma semana, a outra [irmã] fica uma semana. E a outra ficaria as duas semanas aqui, mas, desde abril que minha mãe tá aqui. (...) Eu não tenho ninguém em casa pra arrumar a casa; tem uma moça que passa roupa, o resto da casa quem arruma sou eu, você tem que limpar a casa, deixar a casa habitável. Eu não gosto da minha casa bagunçada, eu me sinto mal; posso estar cansada, mas eu arrumo. (...) Minha casa é muito limpa, não tem cheiro de nada, meus gatos fazem xixi e cocô na areinha e é tudo bem arrumadinho. Cachorro toma banho toda semana, é tudo limpinho e tem que ser né, porque se não, fica tudo perdido.

(...) Carreguei umas caixas de azulejo que sobrou; quando eu tava carregando, me deu uma pinçada, falei: "Não, não... Tudo menos eu ficar mal, não posso...". Tomei um remédio, vambora... O que eu não posso é ficar doente, por que aí descamba. (...)

O que eu penso do meu futuro? Acho que eu não quero muita coisa... Eu só queria mesmo ver minha mãe bem, mas isso aí eu já sei que não vai dar. Acho que só, trabalhar e não ter motivo pra chorar... [...] É gozado a gente pensar o que você quer pro seu futuro agora. Na realidade, eu não desejo nada, está tudo bem. Eu tenho um trabalho que eu gosto - adoro isso aqui, gosto muito isso aqui mesmo, gosto das pessoas, é um trabalho que me deixa feliz - gosto dos meus amigos, da minha família. Não tem nada não... Eu gosto de cozinhar, queria ter 
feito gastronomia, mas agora... Aí eu penso em fazer alguns cursos rápidos, ver uns dias que dá pra eu fazer... E é uma coisa que eu gosto de fazer. Perde um tempo, é trabalho, mas eu gosto... É igual cuidar de bicho da rua: dá trabalho, mas eu gosto... Então, essas coisinhas bobas assim, não tem muita....

Toda noite, tem uns gatos lá perto da minha casa que eu levo comida. Têm três lugares que eu vou, então, eles esperam, coitadinhos... São umas coisinhas, são bravos, mas me conhecem. Encontro marcado! Pra uns eu levo leite e ração, outro não gosta de leite, eu não ponho, mas toda noite eu saio com sacolinha. A Lika [cachorra] vai junto, ela gosta de gato. (...) Pode estar a maior chuva, chuva torrencial; põe o guarda-chuva, eu vou só e eles estão lá. (...) Mas a gente já retirou bastante de lá. Já tirei, já doei. A gente já pegou gato aqui: "Mônica [colega de trabalho] vamos fazer resgate hoje...". E a gente faz um monte de coisa, castra.

(...) Eu comecei com essa história [cuidar dos bichos] - antes eu não ligava muito - quando eu peguei a Sofia. Sou contra esse negócio de comércio de bicho, mas na época eu não pensava nisso. Eu fui numa feira, achei ela tão bonitinha, nem conhecia a raça, era aquela Lhasa, peludinha. Foi em noventa e três, isso. Eu comprei a Sofia, depois que quis devolver; é depressão pós parto. Depois eu comecei a me ligar, eu a minha irmã. (...) A gente começou lá em noventa e três, quando eu tive a Sofia. Dezesseis anos... A Sofia morreu com oito anos. E aí eu comecei a: não tem que comprar cachorro, comprar gato.

Eu peguei a Lika, uma vira lata na rua, em dois mil e três. A Lika está comigo há seis anos. Peguei a Lika numa situação muito ruim também, coitada. $\mathrm{Na}$ verdade, eu não queria pegar, queria só cuidar, castrar e achar um dono mas, não achei nenhum dono, levei ela pra minha casa, está comigo até hoje. E aí a gente começou com essa coisa de cuidar... Nossa já pegamos tantos bichos!

(...) Meu irmão tem um pouco de TOC, e eles não têm minha paciência com sujeira, essas coisas. Ele não tem. Eu falei: "Nem na minha casa tem sujeira, não tem sujeira...". "Não, sua casa é super limpa...". Então, ele falou: "É, mas tem trabalho...". Eu falei: "É, tem trabalho...". Dá trabalho [cuidar]. (...) Tem esses finais felizes, mas é trabalhoso... Eu sofro mais com eles [animais], às vezes, do que com outras pessoas, porque eles não tem do que, estão á mercê. Mas é um trabalho bonito...

Tem muito abandono. Se maltratam pessoas, abandonam pessoas... Que povo é esse? Vai amar um bicho? O que estão fazendo hoje em dia com criança, com velho, com... Uma coisa muito ruim, as pessoas estão ficando muito estranhas.

(...) A minha limitação é genética. Não é coisa que eu provoquei, vamos dizer, não é acidente, alguma coisa assim. Eu queria ouvir normalmente, não sei como explicar essa coisa da limitação. Às vezes é ruim... Não é bom... É ruim você depender de uma prótese e, mesmo com a prótese, você saber que a tua doença pode ir pra frente. Lidar com esse futuro. Eu não quero chegar lá na frente sem ouvir, não gostaria. Nesse pedaço, eu não fico pensando, assim como eu não fico pensando no barulho que ouço. Eu acho que a gente tem que realmente aprender a conviver com isso. Não tirando vantagem mas, às vezes, você até se dá um pouco mais, por causa da sua deficiência.

Sabe aquela coisa: eu não ouço tão bem, eu vou prestar mais atenção. Posso fazer outras coisas que compensem essa minha limitação. Eu sempre tento compensar, eu acho que é isso, na minha cabeça eu tenho que compensar e 
compreender as outras pessoas com deficiência. Eu tenho que compreender o outro, entender o outro, o quanto é difícil. Às vezes as pessoas não têm paciência; o surdo fala alto, é chato pra caramba, você fica gritando com a pessoa. Têm muitos aqui que vem, tem bastante; é gozado que você se identifica.

Às vezes vem: "Cristina, tem um cara que é surdo...". "O que é que eu vou fazer?". "Ah, você não fala [linguagem de sinais]?". Eu não falo nada, mas vou tentar entendê-lo, vou tentar conversar com ele melhor, ou escrever, falar mais devagar e com a boca mais aberta pra pessoa tentar entender. Eu tento entender as outras pessoas e, às vezes, dói ver a deficiência. Quem é cego também eu acho muito difícil...

Eu tenho um primo que foi ficando cego; ele tem a minha idade, teve um problema no olho e foi ficando cego, agora ele só enxerga vulto assim. Nossa, deve ser muito custoso pra ele! Às vezes eu falo com ele, ele é alegre. Ele tira lá a força dele de algum lugar...E ele tem um filho deficiente; ela [a esposa do primo] teve contato com uma pessoa que teve rubéola. Totalmente deficiente, super nervoso, e é um cara já que tá hoje com quarenta anos, tem problema cardíaco. Ele tem problema neurológico, quase não enxerga, super bravo. Então falo: "Ai, eu não sei como que eles conseguem conciliar tudo isso...". Ela trabalha muito e ele tá em casa, mas ele é um cara que está sempre animado...

Gozado... Por que a gente tem que ser assim? Por que eu tive que nascer com essa deficiência? Geralmente eu não pergunto por que, mas o para quê. Tem algum motivo...Eu sou temente a Deus e eu acho que Ele tem motivo para eu ter tido isso e eu tô aqui. Eu tô fazendo o meu pedaço aqui nesse mundo, com deficiência ou não, ou talvez com ela, mas fazendo até muito mais. Se é assim que é pra ser, tem que ser assim e cabou. Não que eu tô aqui parada: "Ai, foi porque Deus quis". Não... Foi assim, mas eu preciso fazer algumas coisas; se dispõe a fazer, que eu te ajudo no que você tiver fazendo. Eu penso desse jeito... Eu não fico lá esperando receber alguma coisa, mas eu acho que a gente tem que se dispor...

[A força] Vem de Deus mesmo. Ele é o meu centro. Ele que me dá compaixão pelo outro, amor pelo outro, a compreensão, a paciência com a minha mãe, com as coisas. Eu acho que Ele me norteia, sem Ele eu ficaria realmente perdida. Eu me converti quando eu tinha dezessete anos e, então, eu o conheço há trinta e três anos, eu tenho cinqüenta anos. Eu sou evangélica... Não teve um dia que Ele não estivesse realmente comigo, todas as vezes, todas as provas que foram difíceis...

Você sabe a história de Abraão? Ele é chamado o pai da fé, porque ele que conduziu, depois de Moisés, o povo... Quando Deus chamou Abraão pra ir pro lugar que ele queria, terra de Canaã, Abraão já era muito velho e Ele falou pra Abraão: "Abraão, dispõe-te... E vai pra terra que Eu te disser...". Dispõe-te... Abraão tinha mais de oitenta anos... "Abraão dispõe-te...", e Abraão foi, sem dizer por quê. Diz que ele era o grande amigo de Deus, ele conversava realmente com Ele, ele é o pai da fé... Abraão, Isaac e Jacó... Abraão teve Isaac já com mais de cem anos, porque foi uma promessa que Deus fez pra ele, que a tua descendência seria como os grãos de areia. Abraão já idoso, não duvidou que ele teria uma descendência, porque aquele que prometeu foi Deus... Muito mais a promessa, mas aquele que fez a promessa... Abraão teve o filho Isaac com muitos anos, mais de cem anos. Sara já era idosa e aquele filho pra Abraão 
era tudo pra ele. Era o filho dele... Um dia - é gozado falar isso - Deus testou a fé de Abraão; Ele viu que Abraão estava colocando o filho na frente Dele.

Então é assim... Eu amo muito minha mãe... Primeiro eu amo a Deus, depois eu amo minha mãe... Sempre assim, sempre foi assim pra mim... Não que Ele imponha isso, mas é porque é uma coisa dentro de mim.

E aí, Abraão com Isaac, ele começou a endeusar o filho e aí Abraão foi testado... Deus foi testar lá Abraão, falou pra Abraão: "Abraão, pega o teu filho... Vai pro monte... E vai oferecer um sacrifício...". Na época, eles faziam sacrifício. O Senhor falou pra ele não levar a ovelha; ele não perguntou, ele foi com o filho. $\mathrm{Na}$ hora do sacrifício, ele mandou o filho dele numa pedra. Ele falou: "Mas e a ovelha?". Não viu ovelha, era o filho o sacrifício dele. O Isaac na pedra... E Isaac perguntou pra ele: "Por que pai?". E ele fala: "Deus proverá...". A ovelha, porque o menino sabia... Quando ele botou e levantou o machado, o Senhor segurou a mão dele e mostrou uma ovelha vindo pra ele. Isso é fé...

Fé é aquilo... A gente crê naquilo que a gente não vê... Eu não posso ver meu futuro, posso achar que meu futuro é tenebroso, eu não vejo meu futuro, eu boto Ele na frente. Ele é a ponte. Ele vai na frente, acertando meu caminho. É assim que eu vejo... Essa tem sido a minha força... Eu sigo ela...

Elas [as pessoas com deficiência] precisam viver, elas precisam de trabalho, precisam ter uma vida produtiva. A gente precisa produzir alguma coisa. Eu acho que teria que ter condições. Hoje tá mais assim, você tem aquela porcentagem nas empresas que empregam deficientes auditivos. Eu tava vendo esses dias uma menina [na TV], ela não tem as pernas, não sei o que aconteceu, é toco mesmo. Ela tem esse tronco aqui e ela fica numa cadeira de roda. Uma coisa mais linda de menina, ela dirige, trabalha no lugar que fez exame, tudo... Então, elas precisam ter vida... Se você não tiver a vida, não se sentir produtiva, aí você vai pro poço... Acho que a sociedade, o governo, precisa dar apoio pra isso, suporte pras pessoas. Às vezes, essas pessoas com deficiência podem nascer em áreas de pessoas que não tem muita cultura e aí que é pior, porque você não sabe como elas vão ser cuidadas, se o outro não sabe...

Até quem tem Síndrome de Down... Às vezes escondiam essas crianças. Então é importante se falar nisso, se orientar, orientar quem tem o filho ou filha; principalmente os pais pra levarem essas crianças para serem adultos, porque vão virar adultos. Adultos produtivos e elas poderem lidar melhor com a deficiência... Porque quando você produz: "Eu tenho isso, mas eu faço isso...". Então não é: "Eu tenho isso... Acabou...". Eu tenho, mas eu sou, eu faço, eu posso. Eu posso me desenvolver. Cada um tem o seu potencial. É difícil assim, mas eu acho dá pra fazer alguma coisa... Encaminhar as pessoas pra algum lugar; são poucos lugares que a gente vê e tudo meio que lotado. São pessoas persistentes pra conseguir alguma coisa e outras você vê, ficavam no meio do caminho. A própria pessoa se conforma com aquilo e tá bom é assim, ou porque não encontrou.

Eu não conheço muito esse universo. Deve ter muita gente, a gente sabe que tem. Acho que hoje, atualmente, tem mais chance do que a gente tinha lá atrás. Principalmente com essa coisa das cotas pra deficiente, você não ser barrado: "Você não presta pra mim...". Você tem um defeito, parece aquele controle de qualidade, o que tá com defeito a gente joga fora. 
A gente vê o pessoal lá, com negócio de frango; aquilo não serve, eles pegam o pintinho jogam na caixa... Ai que coisa horrorosa, gente do céu! Uma vez eu fiz um resgate de um periquito; um periquitinho branco, lindo. Ele tava lá gaiola, eu ia lá visitar, uma casa de aves. Eu gostava de lá, eu conhecia eles tudo. Tinha um periquitinho branco, ele ficava deitado assim, porque a mãe chocou ele com a perninha pra baixo; então, ele não agarrava, ele não ficava em pé. O rapaz falou: "A gente vai ter que sacrificar...". Eu falei: "De jeito nenhum, pode me dar...". "Você vai levar isso assim?". "Vou levar... Vou levar pra minha casa, é tão bonitinho...". Eu fiz uma plataforma na gaiola pra ele, e ele ficou uma graça, ele até saía, voava, se pendurava no varal. Viveu muitos anos... Uma graça o periquitinho; imagina, matar! Ele teve o espaço dele... O bicho deficiente, também tem muito. Cego, surdo...

Eu acho que eu consigo entender um pouco mais a deficiência por ter uma. Você tem mais... Não é compaixão, mas você se identifica com o outro. Então você tenta fazer alguma coisa, acho que você vai um pouquinho mais além. É igual quando um japonês atende o outro, se identificam rápido... É diferente, você não quer, mas é... É verdade... É natural... 


\section{A história de Ângela - "Tudo começa pela gente..."}

Ai meu Deus! O que eu vou contar? Antes eu não tinha isso, essa esclerose. Era bem mais fácil... E agora isso dificulta muito. Eu não sei por onde começar... Foi em dois mil e sete; eu estava passando com a gastro e eu cheguei lá e falei: "Dra. Luciane, eu estou sentindo aqui muito dormente... Com o estômago muito dormente, e a perna muito fraca". Ela falou: "Não! Isso não... Vamos fazer um exame". Quando eu levei o resultado, na hora ela falou assim: "Não, você tem que passar com o neuro", que é o Dr. Sérgio, do lado da sala dela. Foi tudo rápido... O Dr. Sérgio mandou fazer um monte de exames, depois mais outro exame, aí ele falou que era esclerose múltipla. Eu nunca ouvi nem falar... Nunca ouvi mesmo... Pra mim, esclerose era pessoa esclerosada, velha. Mas esclerose múltipla? Agora eu já fiquei sabendo de um monte de gente que tem; até uma artista já tem. Só que tem pessoas que tem menos, não é tão forte, outras têm muito mais forte que eu.

Era pior no começo, foi bem difícil. Agora não sei se é porque eu já aprendi a usar sonda, a controlar melhor, não me cansar tanto... Eu já aprendi um monte de coisa... Foi aqui no tratamento; porque se eu ficasse só em casa, eu não ia saber dessas coisas não. Eu fazia as coisas, eu não parava, eu já acordava cansada... Um cansaço insuportável... E não é! Tem que parar, desligar. (...)

Quando veio a doença, não conseguia fazer mais nada. Eu queria fazer e ficava nervosa, porque não conseguia... Aí veio a bengala também, que já atrapalha muito... Teve uma época que fiquei usando fralda, um bom tempo; porque o xixi, qualquer hora ele vinha, não conseguia travar ele para ir no banheiro. Agora não, eu tomo o ETEMIX e tiro ela de 4 em 4 horas... Aí ficou mais fácil...

Mas, antes era melhor. Eu trabalhava, passeava com meu filho, com meus sobrinhos. Nossa, parece ser uma outra pessoa. Parece quando muda de casa, mudou de lugar, tudo diferente... É a mesma casa, mas tudo ficou diferente... E teve coisa que mudou na casa também: o telefone mudou de lugar, no banheiro já fizemos uma outra adaptação. Então, quer dizer que mudou, alguma coisa acabou mudando. Pano de chão quase já não tem mais, porque eu tropeço nele. Outras coisas...

[A vida antes] Era normal; era bem corrida, mas era normal. Era trabalhar, ir pra casa. Sempre nervosa, muito nervosa... Não sei por quê... Eu tinha doença sim, tinha dor de cabeça, muita dor de cabeça; sempre tive enxaqueca, mas não era nada que me perturbava não. Limpar a casa, ficar em casa... Mas era mais rápido, mais agitado. Agora não, é muito lento! Agora, até uma louça! Eu levo quase uma hora pra lavar um pingo de louça, e não era assim. Eu dava conta de tudo que fazia num dia só. Agora, não adianta que eu não consigo. Eu acho que eu tinha mais paciência. Não que eu era calma; nunca fui calma. Mas, não sei, acho que eu me irritava menos. Agora, não irrito assim pra falar não, eu me irrito mais comigo mesmo...

Eu nasci em Minas, mas eu vim de lá com um ano e quinze dias. Não conheço nenhum lugar, nunca fui lá. Meu pai e minha mãe trouxeram a gente pra cá, minha irmã também; em seguida, meu pai morreu. Eu tinha 7 anos quando meu pai morreu de uma operação plástica, sei lá, estourou, abriu em casa. Menos de quatro anos, minha mãe morreu de derrame cerebral. A gente foi criada com meus tios e depois por uma senhora que não era nem parente da gente. Foi a 
melhor coisa... Ela foi uma lição de vida pra gente, muito boa; era rígida e tudo, mas ensinou a gente a ser gente. (...)

Teve uma época em que cada uma ficou em uma casa; a gente queria buscar minha irmã, só que meu vô não queria. Depois, minha irmã estava conversando com meu vô, e eu fui embora. Deu certo... Depois a gente morou nesse mesmo lugar, ficamos lá pouco tempo. Nós fomos pra Bela Vista, porque a gente chegando em casa, encontrou um menino forçando a porta, e a gente era sozinha, ficou com medo. Eu tinha 19 e minha irmã tinha 18. E a minha outra irmã era pequena, meu irmão, tudo... (...) A gente morou na Rocha e depois na Praça 14 Bis, tudo na Bela Vista; depois, minha irmã casou, a gente foi pra Vila Olímpia. As outras ficaram juntas e eu fiquei com a minha irmã Rosa, que tinha casado. Mas tudo na Vila Olímpia mesmo... Depois, a gente veio embora porque eles queriam o terreno lá; a gente voltou pra nossa casa, que está aí até hoje. Que é a que meus pais deixaram...

A minha irmã comprou uma casa no Jardim Capelinha e casou. Continuou com o marido dela, e depois de muito tempo se separou. E, como eu fiquei doente, ela veio pra cá, ela fica comigo agora. É eu, a minha irmã, a Rosa, e o Lucas [filho]... Ele tem 12 anos. Ele foi a melhor coisa que me aconteceu... Às vezes eu me sinto tão cheia, dá vontade de morrer. Deus que me perdoe! Mas eu penso: "Acho que ele vai sentir falta minha...". Eu sinto até hoje a da minha mãe...

Nós somos em quatro meninas e um menino. Cada um tem sua casa no quintal, sua água, sua luz, tudo separado. E este terreno é bem grande que eles deixaram, então dá pra ter todo mundo junto. Mas a gente não vai todos os dias, na mesma casa, de um entre outro. No domingo, geralmente a gente faz um almoço, vai todo mundo lá em casa. Acho que é por causa da minha irmã Rosa, todo mundo gosta dela...

Quando ele [o médico] me contou [diagnóstico], eu pensei que era uma coisa... Foi até engraçado, porque quando o doutor Sérgio me falou, eu pensei assim: "Agora ele vai me passar o remédio e eu vou sarar...". Ele falou assim: "Ó, você vai ter que levar no posto e tomar as injeções...". "E eu vou sarar né, doutor?". Aí ele falou: "Não, não tem cura. A medicina ainda não descobriu cura...". Eu cheguei em casa e fiquei pensando, a minha irmã procurou na internet, naquele dia a gente foi atrás e já descobriu um monte de coisa.

Mas eu não me aborreço tanto, porque eu vejo que tem gente bem pior; mas tem hora que eu... Eu não vou falar que não me aborreço, porque eu me aborreço sim. Também não fico assim: "Por que comigo? Por que comigo?" Não vai me ajudar. Tem que saber lidar. E foi bem vendo como as coisas aconteciam comigo...

Eu já não posso mais fazer banho quente, me faz mal. Quer dizer, eu já tirei. Eu detesto banho morno, mas tem que ser banho morno. Eu odeio este frio, odeio; desde que eu me lembro por gente eu odeio frio. E agora então... E as coisas assim em casa: não me apavorar para fazer as coisas, não deixar de fazer os exercícios em casa. Tudo que eu faço aqui, eu procuro anotar quando chego em casa... (...) O dia em que eu venho pra cá eu me sinto muito bem, muito bem mesmo.

Eu faço [tratamento] com o neuro; ele é do HC e é da Intermédica. De segundafeira eu tenho ele. E passo ainda com a gastro, porque agora o intestino 
começou a ficar ruim. Mas outro médico não... Aqui é cada dia é uma coisa. Hoje é fisioterapia, a TO e a assistente social; na segunda-feira, é a TO e a psicóloga. $E$, na terça, é a nutricionista, enfermagem e a fisioterapia.

Não é fácil [ir ao centro de reabilitação], mas também não é um absurdo. Não é nenhum absurdo, dá pra vir de perua. Quando dá pra vir de carro, minha irmã traz, quando não, a gente vem de perua. Não, não é fácil! Tem umas calçadas horrorosas, e outra coisa: ônibus tem horário certo pra pegar, não pode pegar na parte da tarde, e nem muito cedo, porque os bancos da frente já estão lotados. Ontem a gente saiu da acupuntura três horas: os ônibus já estavam todos cheios, de idosos, tudo cheio, porque tem muitos idosos que trabalham. Então, fico em pé... Ela me segura [sobrinha], a outra minha irmã me segura...

Esqueci deste detalhe importante, que me deixa agoniada: não consigo sair na padaria sozinha... Uma mulher falou uma vez: "Ai, eu não suporto! Agora é porque eu não consigo sair sozinha...". Eu pensei: "Ah, mas eu? Isso não vai acontecer comigo...". Agora é assim. Não consigo sair sozinha; é que elas [familiares] têm medo de eu cair, porque as pernas ficam muito fracas. E, pra subir no ônibus, descer... Então não deixam. Me irrita isso!

Eu saía sozinha. Quando eu falava: "Já tô indo...", tava longe. Agora, para ir numa quitanda... Mas eu preciso que deixem, sabe, eu sinto isso. Deixa eu ir... $\mathrm{Se}$ eu cair eu vou levantar. Ainda mais ali no bairro, alguém conhece. Me incomoda demais, não sair sozinha. Dentro da minha casa mesmo eu fico sozinha, porque o Lucas só sai [da escola] às seis e meia.

(...) Eu trabalhava na cozinha, mexendo com comida, estas coisas. Era bom... (...) Eu gosto de cozinhar. Levo uma eternidade... Se eu faço as coisas correndo, mais rápido, como era, aí eu me canso muito, tem que parar. Então é melhor fazer devagar... Se eu vou tirar uma casca de batata eu procuro sentar. Eu não ia fazer isso nunca sentada. Aí eu faço assim... Ainda não me acostumei não... Sair sozinha e sair com meu filho é uma das coisas que eu sinto tanta falta. Eu gostava tanto de pegar os meninos e ir no shopping com eles; não gosto de shopping, mas eles gostam. Eles gostam e eu nunca mais fiz isso, não consigo mais. E nem arrisco... Quando a gente viaja, a gente viaja todo mundo junto... Essas coisas ainda continuam as mesmas coisas. É do mesmo jeito, o passeio é igual. Sempre em família. (...) Com a família dá. Sozinha é que não dá.

Eu tenho medo de piorar. Porque eu acho que agora já ta difícil, imagina se eu envelhecer piorando. Por isso que eu não posso parar, tenho que fazer em casa. É continuar, porque eu tenho medo. Eu tenho medo de ficar travada. Morro de medo; e velha ainda. Dá dó, e o trabalho que dá pras outras pessoas: eu não suporto ficar dando trabalho. Assim eu já dou trabalho, imagine... Mas é, é verdade! (...) Isso me deixa doida. Não pode por pano quente... Não agüento isso... E se eu vou envelhecendo piorando meu caso, aí sim que vai piorar mais ainda.

O doutor Thiago passou um remédio pra mim que é pra imunidade, não sei falar o nome direito, para que a doença não venha sempre me pegando. Porque se não, tem que tomar aquela concha, três horas na veia. Mas não tem assim um meio de prevenir. Tem outros que falam que é pra mim não ficar nervosa. A psicóloga mesmo falou: "Pode reparar quando você fica nervosa a doença não fica pior?". Isso é verdade. Principalmente os que já estão dormentes, parecem que dão sinal, é esquisito. E a da acupuntura também pediu pra mim não pegar friagem, porque a friagem piora muito. 
Parece que fica assim esta coisa estacionada. Um dia pensei: "Se alguém quisesse eu como cobaia, eu queria...". Eu não ligo não; se não der pra mim, quem sabe dá certo pra outros. Uma vez a gente viu, tinha uma pessoa que fez uma cirurgia, lá nas Clínicas do interior, e ele tinha esclerose múltipla; ele voltou a andar, não precisou mais de sonda, nada disso, e ele usava fralda. Só que eu já ouvi falar que é outro tipo da esclerose e foi na medula mesmo. (...)

É tanta coisa, tudo que eu não conhecia e nem queria... A minha irmã, a Rosa, tira tudo na Internet. $O$ médico ainda falou que era para parar de procurar. Mas a psicóloga falou que não, pode procurar. Quanto mais saber melhor... Eu quero saber sim, ainda mais se eu tenho o negócio...

(...) Eu tô tão bem estes dias. Estes dias eu tô ótima, se eu ficasse sempre assim... É dor, a fraqueza nas pernas aumenta... É uma coisa assim, um imã, parece que me suga. É horrível! Eu tomei pulso tem um mês já, mas eu tô bem. Eu queria ficar sempre assim, não me canso tanto. Mas quando não to bem... É engraçado, de manhã eu levanto travada, parece que eu dormi amarrada. Posso dormir com a perna esticada, mas é aquela coisa pra levantar. Aí eu fico pensando: "Tá vendo? Eu não posso ficar sem parar de fazer fisioterapia...".

Eu já pensei [em parar] aqui, mas quero continuar em casa. Meu horário é sagrado, eu tenho consciência disso: se eu paro é pior, então tem que fazer em casa. Eu compro as coisas aos pouquinhos, pra não esquecer, senão depois eu vou esquecer e não vou fazer. Tem que fazer... Aqui eu já aprendi tudo, graças a Deus! Eu já aprendi... (...)

Foi com a doutora, lá do HC. Eu passava com ela por causa da bexiga, que não parava; eu comentei com ela que tinha isso daqui. Eu falei: "Doutora, lá perto da minha casa tem um lugar que faz fisioterapia...". "Ah, então eu vou te mandar pra lá...". Ela ia me dando um papel pequeno, ela falou: "Não, vou te mandar um papel maior...". Eu liguei pra cá, não, desculpe, eu vim até aqui. Até aí eu não sabia de nada daqui. O porteiro deu um papelzinho, nós ligamos pra cá pra marcar uma triagem. Não demorou muito... Foi agora este ano. [Antes] Só nos médicos, porque a fisioterapia da Intermédica não cobre muito, acho que só cobre 15 sessões. Aí eu vim pra cá, e aqui é muito bom. É [perto de casa], não demora não. Dá pra vir, a perua agora não é tão cheia.

(...) Às vezes eu me pego tão assim, os outros estão puxando assunto e eu: "Hum, hum...", morrendo pra falar. Mas, sentou perto da Roberta [sobrinha], Deus me livre. Não sei onde ela acha tanto assunto...

(...) É como se eu fosse obrigada a ser [organizada], principalmente com meus papéis. Esse eu sou. Mas, a minha gaveta não é aquela gaveta dobradinha não, meu guarda-roupa também não é todo certinho não. Agora, os papéis, exames, receita, eu gosto... Eu nunca fui de ter uma agenda, agora tenho... É igual os remédios, tudo tem um horário certinho. Tem bastante... (...) Eu faço assim: divido eles, um pouco na minha bolsa e um pouco na cabeceira da cama. Se eu estou em casa eu uso aqueles, se eu estou na rua, eu uso os da bolsa. Se não: "Ah! Esqueci em casa!". Não, não gosto disso, tem que tomar na hora certa...

Ele [o filho] é a minha maravilha. Meu docinho, meu corintiano feliz! Eu gosto muito dele. Ele não é um menino mau; agora tá respondendo, depois de muito tempo, começou a responder. Mas não resposta tipo palavrão. "Vai fazer isso Lucas...". "Ah mãe, depois eu vou...". "Não Lucas! Eu quero agora!". Mas ele é bom, na escola eu nunca fui chamada, na reunião eu nunca tive uma reclamação 
dele. Nunca tive, até agora. Ele tá com doze, tá na sétima série. Ele está maior que eu...

Eu acho que ele ficou um pouco perdido [depois da doença da mãe]. Tem dia que eu nem fazia carinho nele; ele queria abraçar, porque ele adora me pegar pra dançar... Falava: "Mãe! Vamos dançar? Vamos dançar?" Ele adora isso... Ou pegar assim e me abraçar. Ele me pega no colo, eu não posso porque dói muito as minhas costas... E, sair com ele, então nunca mais eu fiz nada isso com ele... Mas a minha irmã sempre lá, e ele sai às vezes com a minha outra irmã. Mas, eu deixei ele um pouco de lado. Na escola, eu ia sempre; teve época em que eu não estava indo nem na reunião dele. Esse ano eu já fui a duas. Mas ele fica assim: "Vamos sair, mãe, vamos passear?". Nunca mais eu andei com eles na rua, de bicicleta. No quintal dá pra andar de bicicleta bem, é grande, não tem necessidade de ir pra rua. Às vezes a gente quer sentar lá no portão, aí sim, pega a bicicleta e vai pra rua. Mas nem isso a gente não fez mais...

(...) Ele ajuda, coloca o lixo na rua, guarda a louça. Só não gosto de deixar que lave a louça porque eu prefiro eu lavar, além de me gastar todo o detergente, não vai lavar direito. Eu não falo isso pra ele! Ele dobra toda a roupa que ele recolhe do varal. (...) Sabe o que ele gosta demais? Jogo... Meu Deus, ele é apaixonado! Ontem tava o Brasil: "Vem ver mãe! Vem ver!". "Ah! Eu não posso, Lucas!". "Vem ver esse gol! Vem ver esse lance!" (...)

Tô aprendendo [crochê] aqui, tão me ensinando aqui na TO. E eu gosto de ver televisão, conversar. Essas coisas... Não tem muito não. Eu sempre queria [aprender crochê], ninguém nunca me ensinava. Eu já tinha agulha, já tinha meia, linha e nada de ninguém me ensinar. (...) Aí uma senhora aqui estava fazendo, eu falei pro menino, que cuida de mim na fisioterapia; ele falou: "Ah! Então passa a cadeira pra lá que ela vai te ensinar!". Eu fui, já aprendi a fazer aquela rodinha e já aprendi outros pontos em volta. Vou fazer uma toalha também. Eu queria ter aprendido antes... $E$, sabe qual que eu quero aprender agora? Já comprei até a argola. Aquele que é uma argola e coloca o pano, prende, fica assim furando... Eu sou louca pra aprender aquilo também... Tricô russo, acho que é isso...

O tear eu não sei, mas a minha irmã sabe, e lá em casa todo mundo sabe. Até meu filho faz; agora ele está fazendo um cachecol amarelo. Não gosto amarelo, se eu falar que não gosto eu vou desanimar ele. É tem que aceitar. E eu vou ter que usar...

Eu não vejo a hora de lixar ela [a bengala]. Acho que eu vou lixar esse final de semana. Já tem mais de dois anos... (...) Eu chego, já gosto de colocar lá no banheiro, já lavo; porque ando em todo o lugar, e dentro de casa eu não uso ela. Ela [a sobrinha caçula] vai lá e pega e começa brincar, e joga pra cima. (...) Eu ficava: "Gabriela pára! Deixa eu ver a novela... Isso tá sujo Gabriela!". Porque está sujo, e já gosto de deixar lá pra lavar, mesmo porque dentro de casa não uso ela.

(...) Tô com o colesterol muito alto. E não é pela gordura; pela gordura ele está pouco. Tá alto, mas não tá muito. É mais pelo açúcar. Eu sempre comi muito açúcar. Sempre... O doutor chegou a pensar que até pode ser por causa de algum remédio, então é pra passar na endócrino...

Teve uma vez que coincidiu: o mesmo médico que eu estava passando, eu fui passar em outro lugar era ele. E agora de novo: passo lá no HC, quando chego 
lá na Santa Cecília é o mesmo médico, o Dr. Thiago. O Dr. Thiago é tão bom. Nossa! Sabe quando coloca um médico que é uma luz na vida da gente? Ele orienta a gente, explica os remédios, pra que eu estou tomando. Não fico só tomando, por tomar, ele fala pra que é.

(...) Agora chegou a cadeira de banho. Porque, quando eu tenho crise, eu tremo muito, ficam muito fracas minhas pernas; e, pra tomar banho, me sugeriram uma cadeira de banho. No começo, eu não queria, aí minha irmã: "Não, não... É mais seguro... É melhor que você não cai...". Eu falei: "Ah, então tá bom...". Aí chegou, não demorou muito.

Eu venho três dias pra cá [centro de reabilitação]. Eu levanto, tomo café com minha irmã às seis horas, minha irmã busca a Roberta [sobrinha] - eu já estou pronta - a Roberta fica só um pouquinho lá em casa e a gente vem pra cá. Pega o ônibus e vem pra cá. A gente fica aqui até uma hora, depois a gente vai embora pra casa - a Roberta vai pra casa dela e eu vou pra minha. Na minha casa, eu vou almoçar; eu procuro sempre deixar a comida pronta, nem que seja o arroz pronto, já para facilitar, porque eu ando demorando muito pra cozinhar. O Lucas, ou já foi pra escola, ou já está quase indo; tem vez que eu encontro ele subindo na perua e eu descendo. Eu vou fazendo as coisas, vou arrumando a casa - bem devagar porque eu não consigo arrumar mais rápido - depois eu descanso, não tem jeito. Parece que me obriga a deitar um pouco! Depois levanto, já estão quase chegando, mexo em alguma coisa para a gente comer à noite; depois chega o Lucas, chega a Rosa, chega todo mundo... A minha sobrinha, não sai lá de casa quando chega da escola... E é isso, não tem muita novidade. Tem vez que eu vejo a novela, tem vez que não, eu já estou dormindo. (...) Eu tomo acho que o remédio, durmo assim e apago.

E o dia em que eu não vou, quer dizer, a não ser quando eu venho pra cá, que é quarta e quinta: eu tenho acupuntura na quarta, sempre onze horas, a Roberta passa lá em casa e a gente vai pra acupuntura. Mas, antes disso, eu boto a roupa na máquina, chamo o Lucas pra ele levantar - pra deixar ele acordado para ir pra escola, pra gente conversar um pouco - eu vejo televisão um pouco com ele. Às vezes, não é nem o que eu gosto, mas também não é justo; ele fala: "Mãe! Vem ver, vem ver...". Eu saio antes dele e ele vai pra escola. Quando eu chego, a Roberta faz a mesma coisa: vai pra casa dela e eu venho embora. E só, não tem muita novidade!

[Antes de adoecer] eu trabalhava, tinha uma vida mais corrida, mais irritada. Trabalhava, depois buscava o Lucas na escola; chegava e arrumava as coisas. Eu arrumava as coisas com muita facilidade, com muita rapidez... Todos os finais de semana eu trabalhava, limpava a casa da minha irmã, a casa do meu irmão. Eu era mais rápida, sentia menos dor nas costas, não tinha essas tremedeiras nas pernas. Mas, eu acho que eu era mais irritada; era um copo que quebrava, daqueles que a pessoa descarta, eu me irritava com aquilo. Hoje não, hoje eu já não sou tanto assim não. Sempre fui muito nervosa. E cobrava de mim; eu falava assim: "Não, eu tenho que fazer as coisas... Tenho que fazer...".

Tinha uma coisa que eu gostava muito também: eu dava mais atenção pro Lucas, saía mais com ele. Agora não! Quando sai, é todo mundo junto ou ele sai com as minhas irmãs. Não é mais aquela coisa individual eu e o Lucas, ou eu o Lucas e o sobrinho, outro sobrinho. Não saio mais só com as crianças.

[A principal dificuldade é] Andar na rua, principalmente. Porque se eu esbarro nos outros, às vezes eu caio, e não posso; por isso, eu não posso mais sair 
sozinha na rua, ninguém deixa. Pegar um ônibus... Isso é terrível! Nossa, ontem mesmo eu tinha acupuntura, a Roberta ia comigo, eu falei assim: "Ah, não Roberta... Deixa que eu vou sozinha...". Depois eu: "Não, vou ligar pra lá e vou ver se eu posso desmarcar...". Porque eu de bengala, de guarda-chuva, de ônibus, não ia dar certo. Ir no mercado, escolher as coisas, ficar segurando bengala... Muitas coisas mudam...

Eu tenho uma irmã que chega a me irritar. Ainda falei com a psicóloga, chega a me irritar. Porque ela ia lá em casa - ela mora na parte de cima e eu na parte de baixo - e ficava assim: "Você melhorou, Ângela? Você melhorou, Ângela?". Mas aquilo me deixava louca, porque eu não falava pra ela; agora a psicóloga me ensinou. Eu queria falar pra ela: "Eu não tô doente, eu tenho uma doença... É diferente... Eu não tô doente... Eu não tô com resfriado... Eu não estou com uma dor de barriga que vai passar daqui a pouco... Não é isso... Agora você fica me perguntando toda hora: Já sarou? Já sarou?". Nossa, ela entrava em casa, me irritava já.

As outras não, elas me tratam com cuidado. Tem horas que me irritam esses cuidados demais. Me segurar muito na rua, eu vou disfarçando e tiro o braço, porque eu quero aprender a andar sozinha. Mesmo que ela está do meu lado, mas eu quero que me solte um pouco. Isso me deixa um pouco chateada, mas elas agora já percebem melhor. Porque parece que te protege demais. Não agüento isso! (...) Eu tenho que prender a me virar. Eu quero, eu preciso aprender, porque se não, eu vou ficar sempre a coitadinha, ou sempre fazendo coisas pra mim, sendo que eu posso fazer. Eu não quero isso! E também não quero magoar ninguém, falar: "Olha, num faz isso pra mim que eu não quero...". Mas vou disfarçando, disfarçando, vou com jeitinho.

(...) Se é um órgão público, é o pior. Olham pra gente como se estivesse despida, parece que vai comer a gente com os olhos. Mede a bengala de cima em baixo, parece que nunca viu gente de bengala. No começo eu achava: "Meus Deus, nossa...". Agora nem percebo mais, já me acostumei tanto, se estão olhando ou não. Mas olham, estranham... Eu me incomodava um pouco, mas agora já acostumei.

Agora, se eu falo da doença, muita gente acha que é esclerosada, confunde. Eu tenho que explicar que não, é na medula, que é uma coisa assim, nas costas. Eu também não sabia! Eu entendo, porque eu nunca ouvi falar isso. Eu ouvi falar quando aconteceu comigo, se não, acho que até hoje eu não saberia. E tem bastante, agora, às vezes, a gente até escuta na televisão. Não é tão pouca como eu pensava quando eu descobri comigo. Geralmente, eu começo contando como começou, no pé, aquela coisa dormente que fica até hoje, as pernas ficaram fracas. Aí eu fiz vários exames, e saiu tudo rápido porque era particular, porque se não, se fosse pelo SUS, ia demorar mais. Aí que eu descobri, o médico falou o que era. Eu achava que tinha até cura, nem sabia que não tinha cura, só por Deus. $E$, tem gente que é bem melhor do que eu, e tem uns que são bem pior do que eu. É uma diferença bem grande uma da outra....

E, uma coisa que você não pode deixar de fazer nunca, é a fisioterapia. Nunca, nunca deixar de fazer... E é sempre a mesma rotina, não mudou nada na fisioterapia, é a mesma coisa. Por isso que eu falei pra eles que eu queria alta, porque tem coisas que eu posso fazer em casa. Mas eu sou obrigada a criar meu horário, deixar o telefone tocar, desligar a panela e esquecer. É aquele horário, é só meu! Se eu não fizer assim, eu vou ficar travada. O dia em que eu faço fisioterapia é bem melhor... Mas, tem dia que eu estou travada; e é um 
cansaço insuportável, eu acordo cansada, parece que me suga. É uma coisa que parece um imã... Nossa, é horrível... E quando eu faço fisioterapia, não! Esse tempo em que eu estou aqui está sendo ótimo, mas eu não posso parar. Ajuda muito, muito mesmo...

Foi o Dr. Sérgio que conversou comigo. Ele falou que é uma doença, que ainda tão pesquisando, tão procurando, e que ela ainda não tem cura. Que tem que tomar os remédios, mas que ele não tinha muito mais pra fazer por mim. Que era pra eu procurar a central da Intermédica, porque tem um departamento que cuida dessas doenças. Eu e minha irmã procuramos e eu estou lá.

Eu conheci [pessoas com deficiência] lá na UNISA, o pessoal tratava lá só esclerose múltipla. (...) Tinha bastante gente, só que eram casos diferentes. Tinha uns que eram bem parecidos com o meu: a urina, o cocô, tinham coisas que eram bem parecidas. $E$, eles tinham uma coisa: não paravam com a fisioterapia. Eles saiam de um canto, faziam lá, faziam na FMU, estavam sempre fazendo, na ABEM. Eles ocupavam o dia deles assim. Eu falava: "Nossa, como é que pode?". Eu não fui mais pra ver, porque era bem contra mão pra mim; lá eu fiquei bem pouquinho, mas eu conheci gente assim. E aquele negócio: tem dia que eu estou bem, tem dia...

Eu nunca mais tomei o pulso, faz tempo que eu não tomo mais pulso. Eu tomo pulso quando eu estou muito ruim, e eu não fiquei mais assim. É um remédio na veia, de três a cinco horas fica aquele líquido pingando. Tem época que eu tomo cinco vezes (é uma semana) e tem épocas que eu tomo só três dias. Agora nunca mais eu tomei, Graças a Deus! Se eu ficar assim, ó, to bem... Eu só não queria era piorar... Até esse cansaço melhorou! A visão está mais a esquerda, mas, eu já tenho dois exames marcados. (...)

[Em relação à deficiência] Uns já nascem, outros é por causa de uma bala perdida. O meu caso é difícil de entender, porque eu não nasci assim, não foi bala perdida, não foi tombo, não foi nada... Então por que eu tenho isso? Eu não entendo também... E ninguém sabe.... Até agora ninguém falou: "Olha, é por isso, por isso...". Eu acho ruim, no meu caso, porque pra dar explicação para os outros... Acho é mais difícil do que pra quem já tem uma outra visão, já nasceu assim, foi um tombo... É diferente, eu não nasci assim. Andava pra baixo e pra cima sozinha, sempre peguei peso, sempre me virei sozinha e, de repente, acontece isso, do nada. Ainda falam pra mim que não sabem nem da onde saiu isso direito... Nossa, foi difícil!

Pra explicar pros outros é difícil ainda... E, perguntam, perguntam... "É a coluna?". "É, é a coluna...". Tem horas que eu deixo, porque se não... Agora, se é um lugar que eu estou indo - que nem no Hospital das Clínicas - que eu vejo que tem pessoas com esclerose, aí a gente conversa. Ela falou: "Ah! Eu também acho que vou precisar de bengala...". Eu falei: "Olha, a bengala é bom, porque segura pra não cair, se a pessoa te vê de bengala, já vai tomar cuidado com você na rua...". Mas agora, se é um lugar que as pessoas não tem nada a ver comigo, então: "É coluna? É coluna...". Eu já não gosto muito de ficar entrando em detalhes...

Eu acho incrível. Tem gente que senta assim perto, e em um minuto, conta toda a vida. Eu não sei ser assim. Eu não tenho nada contra, mas, meu Deus, como é que pode? Eu nunca vi essa pessoa. Minha irmã fala assim: "Às vezes, é uma maneira da pessoa desabafar, ela se sente melhor contando tudo...". Eu acho tão estranho, eu não fico entrando em detalhe, eu não gosto. É o meu jeito! 
Eu tenho medo de piorar. Nossa, tenho muito medo! Pior era no começo, que os outros que tinham que passar sonda pra mim. Mas até que eu não demorei muito pra aprender não. Até porque, eu sempre fui muito assim: eu tenho que me virar. A enfermeira falou que a gente tem um anticorpo, cada um tem um; mesmo com luva, cada um adquire um, então não era bom outras pessoas ficarem passando pra mim. Falei: "Não, eu tenho que aprender...". A segunda deu errado, joga fora. Tem que aprender... A gente pega lá na ONG, lá na Vila Mariana. Às vezes compra também, quando acaba; o mês passado atrasou... Uso de quatro em quatro horas; se eu bebo mais água eu faço mais vezes.

O Dr. Miguel falou que tinha uma ONG, que tinha que entrar com um processo pra pegar essa sonda, porque eu estava pegando muita infecção. Chegava a ficar internada por causa da infecção. Ele falou que era pra mim usar outro tipo de sonda. A minha irmã foi lá, eu fui com ela, a moça explicou, levamos os documentos, tiramos xerox, tudo isso. Não demorou muito... Eu tenho uma sorte! Não demorou muito e eu fui chamada. O posto de lá da prefeitura que distribui os medicamentos caros e eu pego o coletor, o modes e a sonda. ..

(...) Ah, tem que fazer [cuidados com a sonda]. É pra mim mesmo! É isso que eu penso... É igual peso: eu não pego mais peso, não adianta, porque eu sei que vai ser pior pra mim mesmo. Eu já tô ruim - ruim em termos, entre aspas - mas eu não quero piorar. E eu tenho que aproveitar que eu estou melhor esse tempo, agora eu vou ficar fazendo as coisas de qualquer jeito, pegando peso. Já não cuido de nada mais, como eu cuidava antes, então agora vou cuidar de mim! Não tava nem aí pra nada, empurrava cama, sofá, cadeira; empurrava tanta coisa, pegava peso, me irritava com tudo, não tinha hora certa pra comer, nem ligava pra estas coisas...

Olha, é uma mudança horrível, parece que é um outro mundo. Tem horas que eu penso assim: "Nossa, parece outra Ângela, nem parece eu...". Mas, parece que há males que vem pra bem, porque eu era muito mais irritada, agora não. Agora até pra brigar com os meninos, eu tenho mais paciência. Não sei se é por causa dos remédios, mas foi a única coisa [boa]. Eu conheci um monte de gente que falou isso também, que tem essa doença e era muito irritado, sempre foram nervosos...

Eu acho que é a fisioterapia e o medicamento novo [que trazem bem estar], que eu tenho que tomar por cinco, seis anos. Ele demora pra fazer efeito. Eu comecei assim um, um e meio, dois, estou no três e meio. É pra mim parar aqui, ele [médico] falou que tem paciente dele que toma até quatro, mas é pra mim continuar no três e meio e tomar junto com o corticóide. O HC me dá [os remédios], até hoje eu ainda não comprei; eu mando entregar em casa. Seis reais, vêm todos eles, então vale a pena; só o tempo que eu ia ficar de fila lá, é melhor pagar os seis reais. E, porque, só esse outro, ele tá cento e pouco, custa bem caro...

A minha irmã que está aí me ajuda muito. Ela agora nem está lá na casa dela, ela está lá em casa. Graças a Deus... (...)

Eu acho que [as pessoas com deficiência precisam] se ocupar, com qualquer coisa. Mesmo que as pessoas olhem, mesmo que seja um trabalho comunitário, mesmo que seja um trabalho pra ganhar dinheiro, mas sempre se ocupar. Não ficar parado... Eu penso assim... Quando eu ganhar alta daqui, ou eu vou lá pra ABEM ou vou pra Lapa, e eu vou fazer crochê. Falei pra minha irmã: "Agora, eu não vou parar mais em casa...". E procurar sempre se ocupar... Quando eu 
venho pra cá, eu brinco assim: "Agora estou indo pro meu serviço, agora estou indo trabalhar, tô atrasada...". Se a gente ficar em casa, ficar pensando: "Ah, minha perna hoje está tremendo... Ah, estou com tanta dor nas costa...". Tem coisas que é rotina, e parece que é pior...

Eu não ligo muito pra sair pra festa não. Eu acho que não me faz tanta falta e não me aborreço por isso. Eu só sinto falta mais de sair com as crianças. Quando dá, sai eu, minha irmã, sai todo mundo. Mas, pra passear assim, eu não sinto muita falta não...

Eu acho que, mesmo quem não tem deficiência, eles deviam olhar com mais cuidado pra a gente, ou com menos preconceito. Não sei, alguma coisa que ajudasse esse pessoal... Porque tem gente que olha pra gente assim, que a gente acaba até se sentindo mal. Parar de olhar as pessoas com tanto olhar de coitadinho, isso daí aborrece a gente. A gente adora quando alguém ajuda a atravessar uma rua, mas sem aquela coisa de... Isso vem da pessoa, ou a própria sociedade faz isso com a pessoa, deixa todo mundo assim... Não ter dó!

Mas também, se a gente anda na rua, tem umas calçadas horrorosas. Eu acho legal mesmo no Hospital das Clínicas, porque tem aquele corrimão. Eu acho muito bacana. Quantas vezes eu já utilizei aquilo ali! Claro, todo mundo pega, mas eu lavo as mãos, não me importo. Aquele elevador pra pegar o ônibus, muito legal... Lá, até o horário que eu vou, eles respeitam; geralmente são gente que precisa mesmo. Acho que devia ter mais dessas coisas pra facilitar a vida da gente. Seria muito bom...

Tem lugar que não tem nem aquela rampinha, tem semáforo que não tem aquela rampinha pra gente descer, aí você tem que pôr o pé lá, depois o outro, o semáforo já está fechando... É legal quando tem aquela rampinha... Mas é pouco; em bairro não tem, em vila você não acha isso não. A minha, Estrada de Itapecerica, tem que atravessar aquela estrada e o farol lá é rapidinho; eles não respeitam não, principalmente motoqueiro. Vira e mexe acontece acidente! ... E tem aqueles degraus de paralelepípedo, é horrível! Eu acho tão legal, tem uns que parecem que são emborrachados: eu já procuro aquele cantinho, quando eu vejo assim, eu já procuro. Perto do hospital Campo Limpo também tem, mas acho que depois do hospital Campo limpo não tem mais não.

Atravessou a Estrada de Itapecerica, passa a padaria, desce uma rampinha de pedras de paralelepípedo... Aquilo escorrega! O pessoal da padaria lava aquelas coisas de assar frango e costela, e aquela gordura cai. Eu já caí, muita gente já caiu. Eles não têm vergonha! É uma descidinha pequena, mas é uma descida. Desceu fez, virou assim, tem um depósito, tem uma outra casa, tem uma igrejinha e tem a minha casa. Não é muito longe, mas tem esses cuidados...

(...) É muito ruim, e são coisas que poderiam facilitar a vida da gente. A gente andaria bem melhor na rua, com mais tranqüilidade. Eu nem saio mais, quando eu saio é sempre alguém comigo. Eu não tiro a razão delas não, porque, eu sei, às vezes é muito perigoso mesmo. Eu que sou teimosa, que às vezes quero sair sozinha e deixo todo mundo preocupado.

Eu não tenho mais futuro não... Eu só não quero piorar... Só penso nisso! Se eu envelhecer assim, tá ótimo, tá muito bom. Só tenho medo da piora... Quando as mãos começarem a ficar fracas, tenho medo... As pernas... Eu só tenho medo de ficar de cadeira de roda, ter que alguém me levar no banheiro. Dessas coisas eu tenho medo... Mas, eu agradeço... Que nem agora nesses tempos, eu tô ótima! 
Eu seguro pra tomar banho, encosto na parede do banheiro, mas ainda tá bom assim... Eu tenho medo de alguém ter que ficar me ajudando. Isso me dá medo!

Só quero um futuro pro meu filho, quero que ele estude. Porque a gente já é pobre e, sem estudo, não dá! E eu falo pra ele: "Respeite os outros... Você não é obrigado a gostar de ninguém, a respeitar você é obrigado...". É verdade, a gente não é obrigado a gostar de ninguém, mas respeito a gente tem que ter. Só que parece que está fora de moda. Que ridículo! Eu falo: "Não, não interessa! Você tem que ter respeito com a sua professora, o seu colega...". Tudo é violência, todo mundo quer brigar, não, não pode...

Outra coisa é esta história de lan house. Eu odeio isso. Meu irmão fala: "Deixa o menino... Todo mundo vai...". Eu falei: "Todo mundo é todo mundo... Ele é ele... Um dia ele vai... A hora certa ele vai...". Eu não gosto. O Lucas fala assim: "É mãe, mas o Renato vai todo o dia...". Eu falo: "A mãe dele é tia Sandra... A sua mãe sou eu...". Eu tenho medo, sabe, se eu não pegar pesado agora, depois, não vai adiantar. Eu penso assim...

E outra coisa que eu tenho mania, ao chegar da rua, é lavar minhas mãos. Eu tenho essa mania. E ele também, quando ele vem daquela porcaria daquele lan house, falo: "Nem me olha, nem beija, vai direto lá pro banheiro... Lava bem essa mão...". Eu já peguei ele, minha irmã também já, fomos pra ver se ele estava jogando aqueles de arminha; eu detesto aqueles joguinhos de arminha. Não tava... Eu sei, ele tem que saber das coisas do mundo, mas ninguém nunca brincou de arminha lá em casa. Detesto! Ele adora futebol. Ai meu Deus! Eu também sou corintiana, mas ele é demais. (...) Ele é mais alto do que eu, com doze anos é mais alto do que eu. Mas gosta de futebol, gosta de saber de coisas de futebol. Ele tava rindo de um cara, que entrevistaram e falaram assim: "E a Copa Brasil, você acha que vai ganhar quem?". Aí o cara falou assim: "Brasil...". Ele riu do cara. Eu falei: "Lucas, não pode rir... Às vezes o cara não se liga em futebol... É o jeito do cara... Tem gente que não liga mesmo...". Ele achou incrível, um homem não saber nada de futebol.

[Na deficiência] Eu acho que pra homem é pior ainda, para ajudar na rua, principalmente. Uma mulher é mais fácil um homem ajudar ou uma mulher ajudar. Agora, para usar os órgãos públicos, o banheiro, essas coisas, para nós mulheres é terrível. É ruim... Mas ajuda na rua, eu acho que para as mulheres é mais fácil.

Banheiro é uma coisa que deveria ser reservada. Às vezes você vai usar um banheiro, lá com cadeira de rodas, tem gente usando. Entra um cadeirante, eu já vi, muitas vezes... Eu não uso; mesmo eu com bengala, falo: "Não é justo...". Se eu preciso, o outro também precisa... Se eu estou apertada, outro também está apertado... Eu penso assim... $E$, não é todo lugar que tem também não; já aconteceu de eu ir em mercados e ver a pessoa, estar li, não ter, estar tentando passar com a cadeira na porta. E é uma coisa que devia ter, ter bastante, ter em todo lugar... Eu acho que o nosso país não está preparado ainda pros deficientes físicos. Não tá! E tem muito, muito... Pensa que não tem, mas tem bastante... É a mesma coisa quando envelhecer, quando envelhecer esse monte agora, vai envelhecer bastante.

Os deficientes físicos têm bastante, só que é mais escondido. Acho que não sai, não mostra, só por causa dessas dificuldades. Ônibus, são quatro cadeirinhas ali, pronto. Sentou, sentou... De manhã, é terrível. E não são todos que tem um piso baixo pra entrar com a cadeira de rodas. Se você precisa do ATENDE, você 
demora, demora, demora. Ele é muito bom, mas... Já pedi, mas não consegui. É uma coisa muito, muito, muito demorada. Tanto é que a assistente social falou: "Olha, se for pedir ATENDE, você vai acabar o tratamento aqui e não vai conseguir o ATENDE...". Eu acho que tem pouco, e é um transporte ótimo, porque ele já abaixa a cadeira de roda, tem aquele espaço grande, não judia.

(...) Eu saindo [do centro de reabilitação], eu tenho que continuar fazendo em casa, eu sei que eu não posso parar. Mas parece que a psicóloga pediu pra mim falar com o médico, para mandar eu lá para Lapa, que lá tem um curso. Eu não preciso ficar fazendo esses exercícios aqui, eu faço em casa. Ela sugeriu que se eu ganhasse alta, se eu não queria fazer alguma coisa; eu falei que queria. Ela falou que lá tem coisas de cozinha, de informática, de cerâmica, tem bastante coisa; ela deu até um livrinho pra mim olhar. Mas tem que falar pro médico, o que eu posso fazer e o que eu não posso. (...) Ela falou que tem coisas que eu não posso fazer, mas eu não sei o que é...

Eu gosto muito daqui, adorei aqui, mas eu aprendi tudo já. Aprendi mesmo... E já eu já estou bem consciente de que eu não posso parar de fazer em casa. Antes eu não fazia em casa, eu ficava bem rígida; é uma coisa que vai e volta essa rigidez... Hoje mesmo, está mais rígida... Mas eu fazendo exercício ajuda... Não posso parar...

Você imagina o final de semana: minha sobrinha, meu filho... Minha sobrinha: "Pega a bola, tia! Deixa que eu pego a bola... Peraí tia eu pego...". Eu uso a faixa do roupão [para fazer exercícios]: "Ah, tia! Peraí, peraí...". Ela começa a fazer comigo: "Ah, tia, eu tô cansada...". É um sarro! Está de férias, agora vai pra casa da avó dela. [O Lucas] está de férias na escola, mas na crisma não; amanhã ainda tem, é o ultimo dia, ele vai pra casa do pai dele. Porque a gente não foi pra praia, então ele vai pra casa do pai dele; ele não pôde ir antes, por causa da crisma.

(...) Eu não lembro muita da minha mãe, eu lembro pouco. Eu sei que ela era bem brava, batia muito. Isso eu lembro... Ela ficou viúva muito cedo. Ela não perdoava o erro. E depois, logo em seguida, menos de quatro anos ela morreu. A gente foi morar separado. Demorou um tempo a gente ir morar junto, mas eu não lembro muito assim...

É igual, depois que eu tive o Lucas, tem tanta coisa que eu esqueci. Parece que me deu um branco. Eu ainda falo: "Rosa, é engraçado... Eu sempre lembro da minha vida depois do Lucas... Rosa eu não lembro antes dele...". E engraçado! E mudou, mudou, mudou... Mudou mesmo... Foi ótimo... Com toda a dificuldade, mas era tudo que eu queria. Eu já queria, mas não foi planejado.

Antes, eu não lembro muito. Eu lembro que eu morei com minha tia, com quinze anos eu já trabalhava registrada, uma fábrica que embalava shampoo, creme, essas coisas. Era das seis às duas; por eles serem adventistas, não trabalhava no sábado. Era legal... Ah, tem uma coisa que eu sentia falta; quando eu morava com minha tia - isso eu já era de maior, dezoitos anos assim - se eu quisesse ir num lugar, ela nunca me barrava. Ela nunca falava: "Não, não vai...". E eu queria isso, queria mais atenção dela, sentir que ela se preocupava comigo. Mas disse que era o jeito dela. Isso eu não tive na minha infância, na minha adolescência... Então eu fazia o que queria e o que eu não queria; eu tinha que saber o que era certo e o que não era, o que era errado. A minha irmã é mais nova, mas sempre me ajudou, sempre me orientou. A Rosa... Ela sempre tinha 
mais cuidado comigo. E nem morava comigo. Depois, quando ela fez dezoito, que eu fiz dezenove, que a gente foi morar junto.

E eu cobro do meu filho. Cobro mesmo! Porque dá impressão que a pessoa não liga. Mesmo que te ame tanto, mas fica assim: "Ah, vou ali... Tá, então vai, tchau...". Eu podia viajar com quem ela nem conhecia, ela nunca... Tinha pouquinhas [amigas]; eu dormia na casa delas, ela tava nem aí. Também eu não levava ninguém lá... E uma das coisas que falei, que se eu tivesse algum filho, que eu ia fazer diferente também é bater. Não vou dizer que eu não já bati no Lucas, que eu já bati... Pior que eu bato nele, eu choro depois... Então eu falei não dá, ainda mais agora depois que eu fiquei assim, nunca mais bati nele... Eu acho que tem que conversar... E minha mãe não fazia isso... Sabe aquelas pessoas do interior? Ela não fazia isso não... Uma vez ela até quebrou até um cabo de vassoura na minhas costas; mas ela não conversava não. Tem hora que precisa dar uma surra mesmo, mas hoje em dia ainda eu me seguro. Eu dou o castigo, ele sente...

Eu tinha mais cuidado com ele, me preocupava mais com ele. Eu me preocupava e agia... Agora não. Agora eu fico preocupada e fico pensando: "Ai, como que eu vou fazer? Vou pedir pra minha irmã fazer...". Na reunião dele [de escola], eu nunca mais tinha ido, depois que eu vim aqui, que eu fui na reunião dele. Nunca mais... Sempre eu queria saber, mas era pelas minhas irmãs. Eu dava mais atenção pra ele...

E eu sinto que ele mudou. Claro, está crescendo também, mas ele ainda fica querendo carinho. Tem dia que, nossa: "Ai, nem me abraça...". Ele fica assim: "Vamos dançar... Vamos dançar... Larga, larga essa louça...". E eu: "Lucas, pára, me deixa quieta...". "Vamos fazer panqueca...", porque ele adora uma panqueca. Ele e o meu sobrinho já fazem sozinhos, mas eu morro de medo. Meu sobrinho tem dezesseis anos e ele fez treze agora, mesmo assim eu tenho medo. Mas eu acho... Eu acho não, tenho certeza, eu era mais atenciosa com ele... Eu nunca mais passeei com ele, principalmente eu e ele, nunca mais. Agora ele quer que eu leve ele no museu do futebol... Ai, meu Deus!

Ele sabe [da doença da mãe], desde quando começou a surgir, que nem eu entendia. A gente explicou pra ele, eu expliquei, todo mundo. Por mais que ele se toque assim, não demonstra aquela coisa, ele não ficou aborrecido nem nada... Tem vez que eu falo assim: "Ai, eu podia ir na quitanda...". "Não, mãe, não... Deixa que eu vou...". Ou senão: "Vou varrer essa escada...". "Mãe, você não pode varrer esta escada...". Eu falo: "Pára... Pára, que você ta igual a sua tia...". Quer dizer que ele sabe. A única coisa que eu falo pra ele: "Não me deixa nervosa... Porque você sabe que eu fico pior...". Eu já faço um pouco de chantagem... E na escola ele tá bem, graças a Deus! Nunca fui chamada lá, até hoje nunca precisei de falar: "Olha o Lucas aprontou isso...". Não tem nota vermelha. E eu pensei: "Nossa, esse menino vai me dar trabalho agora... Ele vai começar a balançar na escola, vai vim com nota vermelha...", mas não. Graças a Deus!

(...) Eu acho que a gente conversava mais, na mesa do café... Eu sinto isso... Ele sempre fala, até hoje ele fala: "Mãe, vem conversar, vem...". Ele gosta de fazer isso. Porque, agora, eu demoro pra fazer as coisas, eu perco muito tempo; ou se não, eu tô deitada, estou fazendo outra... Eu falo: "Ah, depois a gente conversa, depois a gente conversa...". Ainda converso, mas eu acho que eu dava mais atenção mesmo pra ele... 
Já trabalhei em restaurante, restaurante vegetariano. Já trabalhei na Bancabas, ali perto do Playcenter, quando eu morava lá na Bela Vista, fazendo banco pra moto. Era muito legal... Eu não agüentava mais lá, aí eu pedi pra sair de lá. Trabalhei na lavanderia também e trabalhei na Polivax. (...) E de costura também, na Vila Olímpia. Eu morava lá, nem pegava condução. (...) Aí eu fiquei grávida do Lucas, falei: "Ah, vou sair...". Tinha que assinar o papel, porque eu tava grávida, que não podia sair, assinei. Assuã também, era fita pra impressora, só que eu ficava mais na entrega, na rua. (...) Foi legal também e era bem pertinho, eu atravessava a rua assim, a segunda casa era a minha. Eu nunca fui de escolher, pegava casa de família, qualquer coisa...

(...) [De pessoas com deficiência] Eu conheço a minha irmã, que teve uma bem pequena, por causa de paralisia infantil; mas a dela é bem pequena, quase não aparece, ela puxa um pouco. Eu conheci um monte, mas é onde eu vou, ou pra ser consultada ou pra fazer exame. No meu meio não lembro de ninguém não. (...) $O$ que tem em comum? Uns falam que é a bengala, a infecção (que a pessoa tem muito, de urina), a dificuldade - porque nem todo mundo respeita a gente. A diferença é que uns estão na cadeira de rodas. E comum que eu acho também - e também não comum - é as pessoas para ajudar: tem sempre alguém ajudando. Eu acho lindo aqueles que se viram sozinho, mesmo na cadeira de roda. Eu acho impressionante... Está na cadeira de rodas e roda ela pra lá, roda ela pra cá... Eu não sei se eu seria assim não... Não que eu seja acomodada; talvez a necessidade faz.

Eu sou louca pra sair sozinha e as irmãs não deixam. Hoje seria um dia mesmo, que eu já quase caí, na subida da escada. Ela [a perna] fica tremendo, até ir...[Subo] Às vezes pela rampa, às vezes pela escada... A gente pegou o lanche, aí subimos pela escada. A gente tava subindo pela rampa, eu lembrei: "Ah, o lanche...". A gente desceu...

(...) Eu não tenho o que reclamar daqui. Eu vou sentir muita saudade. Quando eu venho pra cá, eu sempre brinco: "Agora eu vou trabalhar...". Eu não falo que vou fazer um tratamento. Eu brinco, só pra distrair um pouco... É tudo de bom... De ruim, tem que procurar muito. Só lá no Hospital das Clínicas, eu acho que devia ter mais banheiro, porque o banheiro é sempre cheio. É pelo tanto de gente que tem... Mas não é ruim, e não é sujo também não.

Aqui então, é uma maravilha! Todo mundo é tão legal, desde a portaria, a recepção tudo... A gente já chega e eles já sabem até o nome da gente. Eu não suporto ir em um lugar e ser mal tratada, principalmente se é a área da saúde. Eu saio de lá chorando... Você já não está legal, vai pra um lugar que te magoa...

Banheiro horrível mesmo é o da Santa Casa de Santo Amaro. Tentaram arrumar, mas você vê que ainda... Não adianta, porque é muita gente; não é nem culpa de quem está limpando, nem nada disso. É um banheiro só. (...) Tem que arregaçar a barra da calça, que é molhado... Por isso que eu falo: "Minha bengala, quando eu chego, vai direto pro banheiro...". Eu não uso ela em casa, e sempre lavo ela debaixo do chuveiro. Tenho essa mania já, porque se não minha sobrinha pega, começa a brincar... Em casa eu me apoio nas coisas, então... Eu acho muito sujo, bengala, como eu acho sujo; devia ter uma coisa descartável, assim na bengala. Quem sabe eles pensam nisso, eles inventam tudo...

Eu espero não piorar... Foi o que eu falei pro doutor Thiago: "Se eu ficar assim, está bom demais...". Eu tomar pulso de dois, três meses, tá bom. Eu sabia que 
não ia ter melhora de cem por cento, disso eu já estou bem ciente. E aqui o que eu aprendi foi muito bom. Aprendi com a nutricionista, a psicóloga me ajudou muito, a fisioterapia - eu sei que eu tenho que fazer em casa, eu aprendi aqui. E aquela melhora assim, eu sabia que não ia ter mesmo. Mas, eu acho que eu tive melhora mais do que eu esperava. Eu pensei assim: "Eu vou pra lá, vou fazer fisioterapia, mas não vai dar em nada...". E não é bem assim... O dia em que eu faço, tanto aqui, quanto em casa, é uma diferença bem grande. Agora o dia em que eu fico: "Ah, tô com preguiça, tô cansada, hoje eu não vou fazer....", é o dia em que eu fico mais travada. As coisas que eu aprendi na TO, gostei muito. Eu acho que valeu, valeu muito... E não imaginava que o pessoal era tão bacana, sempre sorrindo com gente, bem atenciosos. Para a gente que está com problema de saúde, é ótimo. Porque é terrível você encontrar cara feia ou te responder mal, o que você pergunta... A assistente social também, ela é uma graça, a dona Sonia... Eu vou sentir falta daqui... Mas como eu vou passar com o doutor Moisés, então de vez em quando eu venho aqui ver eles... A gente nunca sabe o dia de amanhã, se vai precisar de voltar...

[Sugiro para as pessoas com deficiência] A fisioterapia e o acompanhamento de alguém. Fazer sempre fisioterapia, e o acompanhamento que eu digo, não é a pessoa vir com você, mas em casa, não se afastar ou ficar com dó de você, não deixar você fazer nada. Isso acaba com a gente! Claro, tem que ter cuidado com a gente, mas não precisa ser aquele cuidado que chega a ser pegajoso, irritar. Porque também, às vezes, a pessoa está doente, está na cadeira de roda, põe lá no canto; você não sabe de nada que acontece, ninguém conversa com você, ou você mesmo não tem como chegar na pessoa, porque a pessoa afasta. Eu acho isso o fim! Tem que sair? Tem que sair... Eu acho que tem que sair, tem que fazer fisioterapia, que é muito, muito, muito importante... Uma, seu corpo não fica parado, vai reagir; outra, você vai conversar com alguém, vai fazer novas amizades... Vai chegar dia em que você pensa assim: "Ah, eu não quero ir... Ah, mas fulano vai hoje, que eu quero conversar não sei o quê...". Incentiva a gente, eu acho que é bom.

Eu ficava nervosa, até chorava de raiva. Eu queria fazer uma coisa, minha irmã: "Não, não pode... Fica aí...". "Deixa eu fazer?". "Não, não...". Era sempre não. Aí ela [psicóloga] falou que era para eu conversar com elas direitinho. Ela me ensinou como varrer a casa, aumentar o cabo da vassoura, e conversar com elas... Porque eu poderia ouvir um sim e um não, mas explicar pra elas, o que eu posso e o que eu não posso, até aonde eu posso. E o meu cansaço também: respeitar o meu cansaço, mas parar com aquela coisa de ficar me podando as coisas. Isso deixa a gente tão mal! Conversei e elas falaram que elas tinham medo de eu me machucar, ficavam com dó de mim. E eu não falava. Eu só falei por causa que a psicóloga me ajudou. Eu falei: "Tá vendo? É isso que eu não quero... Ficar essa coisa assim: não, não, não faz... Não, não...".

Eu sei que eu não vou fazer mais nada do jeito que eu fazia antes, não vou correr, não vou pular corda, não vou subir para limpar a vidraça, não vou me arriscar também... Mas deixa eu fazer da minha maneira e o meu tempo. Meu tempo mudou... Eu levo quase o dia inteiro para fazer uma coisa que eu fazia em três, quatro horas... Mas é o meu tempo... Ela falou pra falar pra elas respeitarem o meu tempo, porque se não fala assim: "Não, deixa que eu faço, que eu vou mais rápido...". E às vezes eu deixava, eu falava: "Droga, deixa pra lá...". E não é, eu tinha que falar... Agora não, agora elas estão legais. Melhorou bastante, até nisso... E conversar, sempre tem uma dúvida, conversar... 
(...) E às vezes eu queria ir num lugar, que nem na reunião, eu nunca mais fui na escola do meu filho. Eu falei com ela e ela falou: "Não... Você vai, conversa com sua irmã e fala que você tá querendo ir... Que você tem condições de ir, só que precisa de um acompanhante...". Expliquei direitinho, eu fui e minha irmã foi junto. Porque eu também não falava, eu aceitava do jeito que elas queriam. Porque elas achavam que tavam fazendo o bem pra mim e eu tava gostando, mas eu não tava gostando. Eu acho que é isso que acontece com os outros, na casa deles. Botam a pessoa lá na cadeira e fica lá; não, não pode! Porque a pessoa já se sente intimidada, você vai discutir uma coisa ainda: "Não, eu quero assim, quero assim...". Não vai falar mesmo... Foi que aconteceu comigo; também não falava... (...)

[As pessoas com deficiências precisam de] Meios para locomover... Esse ATENDE é uma vergonha; desculpe eu falar, mas é uma vergonha. Foi que nem a assistência social falou pra mim: "Olha, você vai acabar o tratamento, o ATENDE não vai ainda te chamar...", de tão demorado que é. É porque tem muita gente...

Mas, eu acho que tudo começa pela gente também. Se a gente não lutar, não começar a conversar, falar o que quer e o que não quer, vVai sempre ficar encostado num canto.

Outra coisa: por que tem restaurante que não tem uma rampa? Só come gente que anda? Eu não sei se você já reparou, mas tem lugar que não tem... Em um bar comum então, pior ainda. Tem que fazer mais rampa, aquelas rampas de rua, aquilo lá é tão legal, porque aí a gente já procura atravessar ali. E divulgar mais esses lugares que tem reabilitação, porque muita gente não sabe. E ocupar, ocupar a pessoa que tem esse problema, ocupar a mente dela... Ela pode ser um voluntário, dependendo do que ela faz, do que ela é, ela não precisa... Pode ser um voluntário, pode ajudar alguém... Melhor do que ficar no canto, vendo televisão ou aborrecida.

Porque eles olham a gente sempre com olhar de coitados. E não é, às vezes não é isso...Quando eu entro no ônibus, na perua, eu sinto... Na rua, se eu ando com a minha irmã... Agora, se você anda sempre, você vai perdendo isso. Eu já perdi bastante. Agora, se uma pessoa olha pra bengala, eu também olho. Não ligo mais! Às vezes a pessoa não tem ninguém na família...

Então eu acho que é isso, é não ficar parado! Eu fiquei parada, fiquei em casa, sentada, deitada, ia no quintal, ficava mais travada... E a mente, aquela perturbação, não sabia mais o que pensar. Preocupada sempre com o Lucas na escola... A preocupação aparece sem ter até, ela vem assim sem precisar de vim... Se a gente se ocupa, ou conversa com alguém do problema da gente, é tão diferente! Pode ser com alguém que tem o mesmo problema ou não. Só não converso com aquelas pessoas chatas, que ficam: "Que isso? Como aconteceu isso? Ah, esclerose... Ah, você é velha... Mas não dá só em velho?". Oh, meu Deus... Como eu vou explicar? Eu não falo; "É na coluna, é um negócio que dá na coluna...". Agora tem gente que já entende legal. E eu também aprendi a explicar, porque eu também não sabia, eu não sabia o que eu tinha. Nasci bem, graças a Deus! O negócio apareceu do nada. Quer dizer que era difícil pra mim também. Agora não, agora eu já sei explicar...

Também teve uma mudança minha. Mas por quê? Porque eu comecei a sair, me interessei mais pra saber do meu problema... Porque se você fica em casa, não se interessa nem pra saber... E foi aqui, foram as cobranças que eu tive da 
psicóloga, da assistência social, da enfermagem, da nutricionista... Foi muito bom! Então eu tinha que falar pra eles, e eu aprendi a falar pros outros. Porque se não, eu ia continuar sempre: "Ah, é a coluna... É coluna...". Nunca, nunca eu tinha ouvido essa palavra, nunca tinha escutado. Não tinha mesmo... Eu escutei com o doutor falando pra mim...

Eu não tenho muito sonho pra mim, não. Eu penso mais em poder cuidar melhor do meu filho, tomar mais cuidado com esse problema, não deixar pegar mais infecção. A recaída eu não tenho como, ela vem de repente e vai embora... Quer dizer que eu já estou bem ciente... O cuidado que eu posso tomar é pra não cair; se eu caio e ralo só joelho, tudo bem, mas o que eu não posso é quebrar uma perna. E mudou bastante coisa, o hábito de vida, mudou bastante. Mas, tenho aquela esperança, aquela coisa mais não...

Não sei, talvez, eu queria até voltar a estudar... Porque eu adoro estudar... Eu entro e saio, entro e saio... Mas cada vez que eu entro, eu aprendo, ficam umas coisas na minha mente que eu aprendi. Mas eu não sei, talvez... Eu gosto muito. Vai ser outro, nossa, tô até vendo! E tem uma escola perto de casa. Tô até vendo, vai dar onze horas e vem me buscar, sendo que não precisa, o ônibus passa na rua de casa. Mas isso aí eu vou bem devagar, bem devagar... Mas também não quero deixar de pensar nisso não... E eu quero ver alguma coisa que tem lá na Lapa, pra mim fazer... (...)

Porque acham que a gente tem essa doença e tem que ficar em casa. Não é isso! Agora, na rua tem muita coisa ainda pra arrumar pra gente. Não sei se é arrumar, mas fazer que as pessoas encarem melhor, olhem com outro jeito... Eu acho que não é só com deficiente físico não, é com idoso também; eles passam um mau pedaço.

Eu queria que tivessem mais coisas alegre pra gente fazer. Não tem baile da terceira idade? Eu queria isso, um grupo, vai fazer não sei o quê... Eu acho que tinha que ter um negócio desses pros deficientes físicos, que seja pros cegos, pro paralítico, que tivesse... Mas tinha que ter, porque tem tanta coisa pra tanta gente... Uns encontros de vez em quando... Até aquele que pode sair sozinho, ia sair, e alguém ia com acompanhante. Eu acho que tinha que ter isso. Isso faz falta! Isso eu acho que não tem mesmo... Eu não conheço... (...) Acho que devia ter feito uns livrinhos: como lidar com o deficiente físico. Não tem aqueles livrinhos quando a criança vai tomar vacina? Eu acho que de vez em quando a prefeitura podia fazer isso, principalmente pros menininhos dessa nova geração...

É engraçado... Na minha época, não tinha criança deficiente na sala de aula. Hoje é tão comum! Comum, comum, comum... E meu filho respeita, os outros respeitam. Eu falo: "Mas você jogou bola com ele? Você não machucou ele?". "Não mãe... Não machuquei nada...". Eu quem fico... Eu já não jogaria com ele, porque fica aquela coisa, aquele medo. [A nova geração] Encara numa boa, brinca. Como tem pra ficar zoando o outro, zoa, joga bola com o menino. Fiquei boba! Porque convive junto... Agora, você nunca viu a pessoa, ela vai entrar no ônibus, você já vai: "Hum, coitadinha...". Ai, como isso, acaba com a gente! Se a gente fala: "Ah, mas não precisa...". "Tá vendo? Ainda quer ser corajosa...". Te juro... A minha irmã fala assim: "Tá vendo? Se você cai ainda, depois o médico vai dar bronca em mim...". Eu falo: "Sandra, não vou cair...". Mas a gente precisa de arriscar...

É isso que eu penso! 


\section{"Não é fácil, mas também não é difícil se você quiser..." - A história de Fátima}

Eu nasci na Bahia, eu sou baiana. Vai fazer 22 anos que estou aqui nesta escola, no dia 15 de agosto agora. Eu tinha muita vontade de estudar... Eu nunca vi assim a luz do dia, nasci assim, deficiente visual total...

Dos meus doze anos para cá, eu comecei a sentir dores na vista; passou muito tempo e cada vez mais complicando e complicando. A gente não tinha meios, e também era pouco de interesse do [meu] pai, ele não se incomodou... Aí, meus irmãos começaram a vim para cá, pra São Paulo... Eu tenho três irmãos; veio o mais velho, depois veio o encostado no mais velho, depois veio o que era encostado a mim... E eu complicando mais... Aí os meus olhos começaram a crescer, ficaram muito grandes... Do meio pro fim, eles começaram a cobrir a menina do olho, tudo branco... Nessa altura do campeonato eu já estava com 25 anos...

Eu fiquei muito mal! E a minha mãe ficou desesperada, porque a minha mãe não podia fazer nada... Depois a minha mãe morreu... Eu perdi a minha mãe quando eu estava com 18 anos... Mas quando eu vim pra cá eu já estava com 25 anos. Eu vim por causa do meu irmão, que também tinha o mesmo problema e um dia se dirigiu ao meu pai e falou: "Pai!...". Nessa época ele já estava melhor de vida, era agricultor, plantou muita cebola, tinha mais ou menos umas condições até de pagar a passagem e me mandar pra perto dos meus irmãos. Meu irmão falou: "Pai, será que o dinheiro que o senhor pega dessa cebola nunca é o suficiente pra mandar essa menina pra casa lá pra São Paulo, pros meninos cuidar dela?". Deus tocou, veio uma tia minha pra cá, eu vim. Meus irmãos me pegaram, me levaram no médico...

Os médicos lá de onde eu morava não tem estudo pra isso. Eles têm até medo, de mexer assim em casos de vista, tanto que as pessoas que tem problemas vão tudo pra capital... Inclusive, a única vez que eu fui, ele falou assim: "Olha! Aqui não tem a menor condição... O problema dela é sério e, pra fazer qualquer coisa, tem que ser na capital...". Em Salvador... Só que, pra ir em Salvador, eu tinha que operar e voltar no mesmo dia, não podia ficar. E eu morava muito longe da capital. Eu morava em Juazeiro; acho que dois dias de viagem...

Aí por fim eu vim para aqui... Um dia eu fui no médico, me lembro como se fosse hoje, eu tava com muita dor... Meu irmão me pegou e falou: "Vamos... Vamos agilizar logo isso...". Eu fui na Beneficência Portuguesa, era o doutor Fernando. Eu cheguei lá, com muita dor, ele deu uma olhada assim, e perguntou o que tinha acontecido. Eu tava com tanta dor que eu não sabia nem o que falar... Ele chamou o meu irmão e a minha cunhada que foi comigo, pra uma sala, me deixou lá.. Daí falou que não tinha jeito... Só que eu também, quando eu saí da casa do meu pai, eu já imaginei que eu tirar as minhas vistas... Ele tornou a voltar, eu perguntei: "Doutor, você vai tirar as minhas vista?". Ele falou: "Não filha, calma!". Daí eu falei: "Não, doutor, não precisa me enganar porque eu já sei. As minhas vistas não têm mais solução.". Ele perguntou como é que foi, eu falei tudo, contei a história... Ele já providenciou os exames, lá mesmo. Eu tirei um raio-x do pulmão e fiz um exame do coração. Ele falou: "Oh, tá tudo ok... Eu fiz estes exames porque ela vai tomar uma anestesia geral, e a gente vai operar". Rapidinho ele, agilizou tudo, já marcou a operação. Ele falou: "Preciso urgência." Ele já falou pro meu irmão e minha 
cunhada que não tinha chance e que tinha que tirar: "Olha! É glaucoma congênito, muito forte, não tem o menor jeito... E tinha! Se ela tivesse vindo pequenininha assim que descobriram, que ela não enxergava...". E quando a minha mãe percebeu que eu não enxergava, eu tava com seis meses de idade...

Eu fiquei muito triste, mas mesmo assim eu fiquei alegre porque ele falou: "Olha, a gente vai operar". Como eu já sabia mesmo que ia tirar, eu fiquei alegre, falei: "Pelo menos da dor eu vou ficar livre, graças a Deus...". Quando os exames estavam prontos ele já me operou... Graças a Deus eu acordei, ainda assim meio anestesiada perguntei, ele falou: "Filha, fica calma!". Operei numa quarta feira, no domingo eu fui tirar o curativo... Eu perguntei, ele falou: "Filha... não tinha jeito...". Ele me contou toda a situação, disse: "Olha, seus olhos já tinham estragado tudo... Não tinha mais o globo ocular, não tinha a menina do olho... Tava tudo assim tudo cheio de carne esponjosa...". Eu falei: "Olha, única coisa que me entristeceu, doutor, foi o senhor ter dito que eu tinha uma grande chance de enxergar, se eu tivesse vindo pequena... Mas só em tirar as dores, eu estou me sentindo como se eu enxergasse...". Porque eu não tinha prazer de comer, eu não dormia... Era tanta lágrima que saia, que eu não sei de onde vinha tanta lágrima que saía... Foi uma coisa assim horrível que eu não desejo pra ninguém!

A mesma coisa aconteceu com meu irmão, que também teve o mesmo problema. E este mesmo médico que me operou, operou ele também. Aí a gente foi batalhar pelas próteses. Eu passei sete meses aqui, até sarar... Fui batalhar pelas próteses, porque era o SUS que ia dar e realmente foi ele quem deu. Foi muita batalha, porque era muito caro naquela época; era não, é. Os custos vão subindo cada vez mais. Quando eu coloquei as primeiras, ia ficar duzentos e vinte o par. O doutor fez o maior empenho, escreveu uma carta lá pro SUS... Naquela época nem era o SUS, era o INPS... E escreveu contando a minha situação. Eles demoraram a mandar... Depois me ligaram, pra ir medir as próteses em Santos, eu fui... Não conseguiram... Mandaram eu tornar a voltar, eu voltei... Demoraram... Olha, eu operei em janeiro e fui colocar minhas próteses em abril... Era para colocar com um mês. Ele falou: "Olha um mês ta bom! Já sarou...". Teve um dia que ele escreveu uma carta muito mau criada, chamou eles de burro falando assim: "Será que vocês não entendem que quanto mais demora, as próteses não vão servir, porque o globo ocular vai afundando?". Até que graças a Deus ele conseguiram, eu coloquei, e fui embora. Meu pai veio e trouxe meu irmão, fez a mesma coisa...

Mais de vinte anos eu fiquei com ela, mas depois precisou trocar... Graças a Deus uma faculdade aqui me deu uma, já estava quatrocentos... Acho que há uns cinco ou seis anos, eu tornei a ganhar outra. Quando eu fui trocar já tava oitocentos reais. Elas são de acrílico e, de seis e seis meses tem que polir. A gente vai polir em São Paulo. A última vez que eu poli, já tem mais de dois anos; são trinta reais cada uma prótese para polir. Tem que pagar isso também.... Você vai polindo, vai polindo, vai polindo... Chega uma hora que elas não têm mais o que polir, elas vão ficando arranhadas. Tirando e colocando sobre a mão, você não percebe que elas estão arranhadas, mas no fundo elas estão arranhadas de tanto polir e machuca a cabeça do olho, o globo ocular dói muito, começa a sair secreção... Aí é hora de trocar... Quando eu fui trocar agora, eu não consegui. Foi uma pessoa que me deu; ela falou: "Olha você não precisa me identificar que foi eu, eu não quero que fale...". Mas ela foi quem deu seiscentos reais pra mim e eu troquei. Eu não posso comprar nenhuma... Eu ganho o benefício do LOAS, que é pra mim pagar meu aluguel. Fica super difícil trocar... 
O médico me indicou esta escola, mas a minha família não queria que eu viesse estudar... Eu voltei pro norte de novo, pra casa do meu pai... Quatro anos eu passei lá; com vinte e nove anos decidi que eu ia estudar. Mas, meu pai não queria que eu viesse. Eu falei: "Ah, vou!". Voltei, cheguei, minha família também não me deu maior apoio para eu estudar. Eu decidi que iria estudar... Graças a Deus naquela época tinha o internato, eu vim morar aqui. Eles começaram a colocar muito empecilho; a diretora falou: "Olha! Você vai ter que escolher, ou a família ou a escola...". Eu optei pela escola, e abandonei a família, porque eles não me davam maior apoio em nada... Depois eu segui, acabou o internato, fui morar com a moça no São Vicente, arrumei um serviço de doméstica, trabalhei uns seis meses com ela. Depois, por situação financeira, o esposo dela me mandou embora, eu fiquei na cada uma amiga que eu conhecia, que veio fazer estágio aqui. Aí saiu esse LOAS, inclusive foi ela quem deu o primeiro passo, esta moça que eu morei. Depois eu ajuntei com umas colegas que hoje são casadas e tiveram filhos. Antes de casar a gente alugou um apartamento e moramos, depois ela decidiram a casar aí eu falei: "Bom agora eu tenho que dar um jeito em minha vida...". Resolvi morar sozinha. E hoje estou sozinha, moro sozinha, moro na zona Noroeste, na minha casa...

Mas foi muito difícil, não vou falar pra você que foi fácil... Fui aprender a andar na rua, eu não conhecia uma rua, eu não sabia o que era uma esquina... Porque os meus pais me traziam muito presa, eram muitos cuidados, eles não deixavam eu sair para lugar nenhum. Então, quando eu fui fazer locomoção, eu não tinha noção nenhuma sobre o que era uma rua. Sofri muito, mas muito mesmo... Eu não quero dar uma de vítima, mas foi muito difícil pra mim chegar aonde eu cheguei. Mas graças a Deus! Eu me alfabetizei, aprendi o braile aqui, com a professora Dilma, depois eu fiz o supletivo, comecei a estudar fora, concluí o primeiro grau e agora eu estou fazendo o segundo - quando tem as provas eu elimino. Com muito trabalho, mas estou conseguindo... Mas também graças a Deus só vou fazer isso! Só vou fazer só o segundo grau e vou parar porque não estou mais com paciência...

Tem os altos e os baixos, mas dá pra gente passar... Eu aprendi uns cursos aqui [instituição]. Depois que eu estou aqui, aprendi a fazer salgados aqui, aprendi a fazer doces, e inclusive eu faço salgados pra fora pra vender. Eu faço sequilhos de porvilho pra vender. E com isso eu vou sustentando a minha casa também e a mim... Vai dando uma ajuda... Graças a Deus que tem muitos amigos que também ajudam, e eu vou levando a vida. Não é fácil, mas vou levando a vida... Não é fácil, mas também não é difícil se você quiser...

Hoje em dia, eu faço educação física, hidroginástica e eu jogo gol ball. Nós disputamos campeonatos lá fora; inclusive agora, vamos começar o regional, acho que é em maio, em São Paulo. Já fomos no Rio... Eu faço computação, eu canto no coral e nos domingos eu vou pra igreja... Agora eu vou pra todo lugar... Inclusive agora em julho eu vou pra Bahia ver o meu pai; já fui duas vezes sozinha, porque - graças a Deus - o governo liberou o passe livre, e eu consegui o passe. Então todo ano eu vou ver o meu pai. Este ano eu não fui porque eu tinhas umas coisas, tinha umas prestações e eu tinha que esperar um pouco, mas agora em julho eu vou ver o meu pai. E essa é a minha história...

O que mais me chateou, o que mais me deixa assim, triste, é não ter apoio da família. Nós éramos seis irmãos; um ficou lá, o caçula veio pra aqui quando eu vim e não deu notícias, nunca mais foi lá ver o pai, e tinha três aqui, que eram os mais velhos. Sempre em Santos... Eles casaram... Mas só que eles aqui também eles não me davam apoio... (...) Olhava as crianças, cuidava da casa e 
tudo... Só que quando era pra eu estudar, para eu crescer, eles não queriam... Foi aí que eu saí...

(...) Então eu fico triste porque eu tenho mais apoio das pessoas estranhas do que da minha família... Mas não tem problema não, eu tô bem graças a Deus! Graças a Deus! Já pastei muito, mas hoje estou... E eu devo muito a escola sabe porque a escola me apoiou muito, por ter me apoiado. Hoje Graças a Deus...

Foi o Dr. Fernando quem me indicou aqui. Só que eu vim pra cá e depois eu voltei, porque os meus irmãos não queriam que eu viesse ser interna aqui. Depois eu encontrei uma amiga das minhas cunhadas, e esta que me deu maior apoio, foi ela quem veio aqui procurar a escola, falou com a diretora. Eu vim aqui dar a entrevista, foi quando eu fiquei também. Devo muito a ela, devo a Deus em primeiro lugar, ter encontrado esta escola que é maravilhosa! Tem me apoiado em tudo. Graças a Deus! Abaixo de Deus eu tenho esta escola e foi ela que me fez crescer! Hoje eu posso dizer, hoje eu sou gente! E agradeço muito, muito o Lar das Moças Cegas, muito mesmo! Muito mesmo! Isso eu vou agradecer enquanto vida eu tiver e acho que até depois de morta, por que a escola me apoiou muito e tem me apoiado.

Eu acho que este ano agora já deve estar com seus trezentos alunos; se não tiver, está chegando. E tem uma lista de espera que não tem fim... A gente vem e não quer sair pelo seguinte: tem muito companheirismo aqui, conhecemos muitas pessoas legais. (...) Então, você vai criando um vínculo como família... E, além disso, os cursos que tem aqui... Que é muito importante! Por exemplo, os cursos que eu faço: é muito importante para minha saúde. Eu tenho vários problemas de saúde, e preciso de exercícios. $\mathrm{E}$ aí o pessoal que vem não quer sair... Então vai crescendo aquela lista... Porque na baixada santista tem tido muitos deficientes visuais e só tem essa escola aqui...

Eu trato tudo, os vários problemas de saúde que eu tenho... Na saúde, olha já teve melhor... Quando era ali no SUS, ali na Alexandre Martins, eu tinha um médico, o Dr. Wander Ajax, que era um amor de médico... Aliás, todos os meus médicos dali, todos foram uns amores... (...) Eu chegava lá, podia ta quem quiser, ele já pegava minha mão, me levava pra sala... E eu: "Não, doutor, não faz isso!". "Ah! Você sabe que tem prioridade aqui...". Só que quando ele saiu e eu fiquei assim, igual ovelha desgarrada, eu fiquei órfã... Porque ele agora está sendo do centro de saúde, acho que lá do Guarujá... Agora, eu to com outro médico e não tem ainda o médico afetivo. (...) Vai trocando... Então não tem aqueles médicos, você já conta seus problemas, aquele médico fixo... Não tem! (...) É muito ruim... E assim sobre a saúde, tem essa que eu freqüento na Rebouças e tem um agente de saúde, um postinho lá no zona noroeste, onde eu moro. Só que ainda não tem médico, também fixo; inclusive agora tava sem médico... Eles falaram: "Ah! Você transfere tudo pra lá, porque lá está pertinho de sua casa...". Realmente está perto da minha casa, mas não tem médico! Eu fui lá medir a diabetes, fiz a carteirinha, pra mudar tudo pra lá. Até que, no mês passado, eu fui lá tava sem médico... Eu falei: "Deixa como ta. Quando tiver um aí eu volto...".

Só que ali no Rebouças [unidade de saúde da qual é usuária] eu ainda não sei ir sozinha, é uma amiga minha que leva. E essa amiga também que tem me ajudado muito. Muito! muito! muito! Ela é daqui [instituição], é baixa visão também. Ela é professora, trabalhou em Sorocaba muitos anos, depois veio pra aqui, trabalhou e depois ela se aposentou. Já tem muito tempo que é 
aposentada... Nossa! Ela é uma pessoa maravilhosa. É ela quem me leva nos médicos, quem marca consulta.

(...) O meu problema visual, eu não reclamo muito pelo seguinte: porque eu nunca vi... E tem uma coisa de bom, a minha mãe, ela nunca me criou como deficiente visual... Ela sempre foi uma pessoa que me ensinou a fazer tudo... Tudo! Ela me ensinou a lavar louça, a me ensinou a limpar uma casa, ela me ensinou a passar, menos a cozinhar... Isso ela tinha medo. Como a gente morava no norte, e tinha assim um fogão a lenha... Pobre é pobre... Ela saía e falava: "Olha, a comida deixa que eu faço...". Só que eu era curiosa.Ela saía e eu ia fazer escondido, ia fuçar... Eu via ela fazer, como coloca o feijão no fogo, como fazer café, eu ficava ali só ouvindo ali. Uma vez ela saiu e eu comecei a fazer as coisas; quando ela chegou, eu tava fazendo café... Nossa! Ela quase me matou: "Eu já falei não mexe com fogo! Eu não quero que você mexa. Você se queimar e ainda vai me dar trabalho...". "Mãe, eu preciso aprender a fazer!". "Não, você não vai aprender a fazer coisa nenhuma... Cozinhar não! Você vai me dar trabalho...". Ela saiu e eu fui fazer: "Vou por o feijão no fogo...". Quando ela chegou eu já tava temperando o feijão. Ela falou assim: "Olha, quer saber de uma coisa... Seja o que Deus quiser! Você é teimosa mesmo... Você não vai me ter a vida inteira... Então tá nas mãos de Deus. Se tiver que ser queimada, vai queimar, se não tiver...". Aí pronto! Quando eu era garotinha, eu tinha o que, doze, treze anos, às vezes ela saia e eu já não tava mais a fim de fazer, queria brincar com as colegas. Quando ela chegava, já cobrava: "Mas você não fez o almoço, não limpou a casa!". E graças a Deus, a minha mãe ela nunca me criou como deficiente visual... Graças a Deus! Eu louvo a Deus por isso, porque também se tivesse me criado, tinha me paparicado muito e eu tinha sofrido mais...

[Tenho dificuldade] Só no que eu não sei... A única coisa que eu tenho dificuldade é de costurar. Só isso! Assim, pode ser que apareça outra coisa que eu não fiz, provavelmente eu vou ter dificuldade, mas lavar, passar, cozinhar, limpar, fazer comida, isso eu não tenho. Limpar minha casa, arrumar minha casa... Tudo! Não tenho dificuldade... Fazer supermercado...

(...) Eu vou no supermercado, chego lá eu ficou esperando alguém; vem as pessoas me atender, fala: "Você quer ir aonde?". Eu falo assim: "Eu quero ir na seção de tal...". (...) Eles me levam lá... (...) Só em lojas de roupas que até tinha [alguém pra ajudar], mas elas fingiram que não me via... Na Marisa e na Americana... Eu deixei de comprar lá! Outro dia eu fui lá e falei: "Olha, eu deixei de comprar aqui, de fazer compras aqui, por causa que vocês fingiram que não em viram... Então eu fiquei aqui um bom tempo, e vocês atendeu todo mundo que enxerga e não me atenderam...". Agora não, agora eu vou lá e elas já me ajudam...

Eu tenho um irmão - acho que depois que ele apanhou muito da vida, ele já ta mais assim - mas ele tinha vergonha de andar comigo... Agora o mais velho não, porque o mais velho, nossa! Ele me pegava assim, passava o braço em minha cintura e a gente ia embora... O outro foi quem ajeitou o médico para me operar, quando ele ia sair comigo, ele pagava táxi, pra não sair comigo.... Meu pai, meu Deus! Meu pai é um exagero pra andar comigo... Meu Deus! Ao invés de pegar na minha mão pra sair, ele me põe na frente, segurando pelos ombros e me empurrando... "Pai! Pelo amor de Deus! Não é assim que se conduz um deficiente visual. Dá o braço, pai!". Ele não gosta. Não sei se ele não gosta, ou ele não tem ou ele não sabe... Agora esse meu irmão, ele tinha vergonha... 
(...) Agora na rua, de vez em quando você encontra preconceito. De vez em quando... O pessoal ainda não acostumou... A sociedade ainda não acostumou com os deficientes visuais... Eu já vivi assim uma coisa que eu fiquei muito constrangida: eu fui no Humaitá, inclusive onde meu irmão mora e entrei no [ônibus]. Porque o deficiente entra e sai pela frente... Naquela época ainda tinha cobrador, então eu entrei e sentei... O cobrador entrou, ficou ali e depois o motorista entrou, ele olhou assim pra mim e falou: "Escuta! E isso aí, quem cuida disso aí?". O cobrador falou assim: "Ah eu não sei! Eu cheguei e já achei isso aí...". Eu falei: "Escuta, vocês estão falando de mim?". Ficaram quietos, eu falei: "Olha, é o seguinte, eu não sou isso... Eu vou mostrar minha identidade pra vocês... Eu tenho 35 anos, me chamo Fátima... Então eu não sou isso... Eu sou gente, e uma cidadã igual a vocês... E vocês estão fazendo isso por quê? Porque eu entrei e não paguei? Eu entro e não pago porque é lei... Deficiente visual ou qualquer tipo de deficiência, a gente não paga, você sabe muito bem disso... Então eu não to tirando nada de vocês, eu tô viajando no que é meu... E eu pago! Porque de qualquer maneira eu moro de aluguel e pago imposto da casa do dono que não era pra mim pagar... Então quem paga sou eu.... Então eu não sou isso!". Eles ficaram quietinhos, não falaram nada, nada... Daí pra cá, graças a Deus...

De vez em quando, você tá no ponto - quando não tem ninguém - você ta com a mão e eles vão embora. Já outros não, já outros são mais compreensivos, eles param... Tem um aí [motorista de ônibus], do 154, quando ele passa lá no ponto, que eu venho pra cá, se ele me vê sozinha, ele não pára, vai embora. Eu já liguei pra SPTO duas vezes, eles falam: "Oh! Você tem que pegar a placa dele, pra gente dar uma chamada nele, porque assim é difícil." Eu não enxergo! O problema sou eu, se tiver mais gente ele pára, mas se não tiver, ele já sabe e ele não pára. Agora os outros não. Graças a Deus!

(...) Eu sou uma pessoa que sou muito fascinada em coisa de cozinha. O meu sonho era montar uma cantina, trabalhar só com deficiente visual, ensinar o que eu sei... Nunca a gente vai trabalhar totalmente só com deficiente visual, porque a gente precisa, mas assim, poucas pessoas: um pra fritar e outro pro caixa, que tem que ser uma pessoa de confiança... O resto eu me virava... Mas como eu sei que é difícil montar uma cantina... Se eu achasse um lugar pra trabalhar, aí sim, eu ia me despedir do Lar das Moças Cegas. Mas por enquanto eu ainda não consegui. Eu já tentei, pensei até em fazer um empréstimo na Caixa, mas só com o LOAS eles não fazem. Então é difícil... Mas eu tinha este sonho, o meu sonho era trabalhar com a cantina... Eu tenho um pensamento assim, se um dia - ainda eu espero em Deus - se o senhor Deus me mandar um marido bom, eu vou sair daqui também. A gente vai trabalhar em casa nós dois. Aí eu saio...

Este ano eu ia fazer chup chup... Mas eu fiquei um pouco depressiva - coisa que eu nunca tive - e não tive vontade de fazer nada. Porque é assim, você mora só, mas chega um dia que você sente falta de alguém. É horrível! E não sei por que eu fiquei depressiva, assim de um momento pro outro... Eu fui no médico, fui ver o ginecologista, ele falou que era da menopausa, que a menopausa às vezes dá... Não é todo mundo, mas algumas pessoas tem... Ele me deu o remédio, e graças a Deus... Mas eu ia fazer chup chup pra vender em casa... Agora que eu to pensando, mas o ano que vem eu não sei. Se nada acontecer, eu pretendo fazer...

Mas aí tem um porém: a minha cozinha é pequena. Eu preciso de um freezer pra isso, e a cozinha não tem tanto espaço. Mas eu vou ver o que posso fazer... Cobrir um pedacinho da área lá e colocar um freezer. Porque a gente tem que 
fazer, sabe, a gente precisa... Por vários motivos: um aumentar renda e, segundo, você não pode ficar com a mente parada, a cabeça tem que funcionar, tem que fazer qualquer coisa...

O meu pai quer que eu volte pra Bahia, mas eu não quero. Porque na Bahia não tem nada pro deficiente. Nada! Absolutamente nada... O deficiente lá só come e dorme e engorda, e eu não quero essa vida pra mim, não quero. Eu já falei pra ele: "Olha pai, enquanto eu puder pagar o aluguel aqui, eu não pretendo ir embora.".

(...) Acho que faz uns dez anos [que tem o LOAS]. Eu consegui e depois eu perdi, tomaram... Eu tive que entrar com o advogado, foi até o Lar das Moças Cegas que me arrumou este advogado... Depois de muito tempo... Naquela época eu morava com quatro colegas, todo mundo tava pagando o aluguel e eu não podia dar minha contribuição no apartamento; essa amiga que eu conheci, foi quem começou a pagar pra mim... Depois de três anos eu voltei a receber. Eu recebi os atrasados, e o que que eu fiz? Como essa amiga me ajudou muito, eu dividi meio a meio pra ela. E o doutor ele não cobrou nada pra mim, mas eu peguei assim um dinheirinho e dei pra ele. Eu não achava justo! (...) Eu fiquei com dois mil e foi com estes dois mil que eu resolvi morar sozinha. Eu fui arrumar casa, comprar as coisas pra casa... É um salário mínimo, só... Não tem décimo terceiro, não tem nada. Ele só aumenta quando tem de aumentar, quando o salário aumenta. Se não, não aumenta...

(...) Eu não conhecia ninguém... Eu vivia dentro de casa trancada, meu pai... Meu Deus do céu! Meu pai era meio terrível, ele não deixava eu sair para lugar nenhum... Nem o meu pai, nem a minha mãe; a minha mãe até que era mais light, mas meu pai era bravo... Eles não deixavam, tinham medo...

O que tem de diferente, igual e desigual, é que uns [deficientes] são mais ativos e outros já não são. Eu conheci uns deficientes que eles tem medo de sair, de enfrentar, de dar a cara pra bater; e outros já são mais assim, uma Fátima da vida, já são bem doidão... É difícil aqui pra competir comigo... Se conta... (...) Os outros que vão é porque eles baixa visão, eles conseguem ver um pouco, então eles não tem tanto medo... Mas os outros que eu conheço, eles tem muito medo de sair sozinho...

O medo existe mesmo porque aqui, acolá, a gente encontra pessoas maldosas e o medo é esse! Eu já encontrei com pessoas maldosas. Eu já encontrei com estrupadores, e foi terrível... (...) Outras pessoas enganam a gente, dizendo que é um ônibus e não é, é ônibus errado... Outras pessoas, você pede ajuda e não ajudam... Então as pessoas tem medo de sair. Só que se você não sair, você não vai ver o mundo lá fora da sua maneira, você vai ficar sempre com medo... (...) A diferença é essa, muitos tem medos, outros não têm. Mas a maioria que eu conheço, até os que eu conheço aqui, eles não são corajosos. E outra coisa... Eu sou uma pessoa que devido eu ter pastado muito em minha vida, antigamente quando eu não conhecia de lei, quando eu não sabia ler - eu tinha medo de procurar os meus direitos. Hoje eu já não tenho, eu não tenho medo de enfrentar, de bater assim de frente com quem quiser, atrás dos meus direitos. Antigamente eu tinha, já hoje não... Eu não vou assim, brigar; eu vou sentar e conversar e falar: "Olha! Dos meus direitos eu não abro mão!". E muitos ainda não vão: "Ah! Deixa pra lá! A gente não enxerga mesmo. Ah! Não vou mais atrás disso...". Ah, não! Eu não abro não dos meus direito não, porque pra conseguir eu chorei muito, perdi muito sono... (...) Porque eu acho assim, se você for na estupidez você não vai conseguir nada, mas se você for na calma, 
conversar, você consegue tudo! É só ir com educação! E muitos acham que porque eu sou cega e não vou! Eu vou! Eu vou! É um direito meu! Claro que eu vou! Eu não tenho medo de conversar com ninguém, eu vou numa boa...

Antigamente, meu Deus do céu! Eu não tinha coragem de conversar com ninguém, de jeito nenhum... Eu não conhecia nada, não conhecia nada de lei... Só que agora não... Teve muitas reuniões e daí a gente foi conhecendo os nossos direitos, quais eram os direitos dos deficientes... E aqui também, eles buscaram muitos direitos dos deficientes visuais e foram passando pra gente. $O$ serviço social, a direção... Elas foram atrás dos direitos e foram passando pra gente. E aí eu fui crescendo, então hoje em dia eu não tenho medo de falar com qualquer um, e nem de ir buscar.

Quando eu perdi meu benefício, tinha a assistente social, Amália, e eu fui lá [no INSS]. Eu não tinha ninguém, eu fui sozinha. Ela foi muito grossa, falou assim pra mim: "Eu já falei que não quero você mais aqui. Só é pra vir aqui quando eu chamar... Você sabe que você perdeu o benefício, você tinha renda e você mentiu...". Eu falei: "Eu não tinha renda nenhuma. Quem colocou aí no documento que eu tinha renda, se enganou. Eu falo isso e provo pra senhora, porque de renda eu só tinha esse LOAS. Eu agora eu tô morando de favor...". "Mas não é mais pra vir!". Eu falei: "Olha, eu só vou falar uma coisa pra senhora, um dia eu volto... Eu vou conseguir meu benefício de volta, porque isto aqui não é da senhora... E eu volto e a senhora vai estar aqui. Pode ter certeza que eu volto...". Mas não deu outra. Quando o juiz deu a sentença, o advogado me ligou, eu lembro como se fosse hoje, era oito horas da noite, o telefone tocou e eu fui atender: "Oi Fátima! Tudo bem? Eu tenho uma ótima notícia pra você... Você conseguiu o benefício...". Eu falei: "Não acredito, doutor!". "Amanhã mesmo a gente vai em São Vicente, eu já vou assinar todos os papéis para você tal dia ir retirar o dinheiro, com o atrasado de tudo... Precisa de tantas testemunhas.". Consegui as testemunhas, a minha amiga que agora ta sendo minha procuradora... (...) Foi eu, ela, a testemunha e o doutor... Quando eu cheguei na porta, olha quem é que eu encontro? "Bom dia, dona Amália! Eu não falei pra senhora que eu voltava um dia? Eu voltei! Vim pegar o que é meu...". Peguei o papel e falei: "Aqui, oh... Consegui! Ou a senhora acha que por eu ser pobre, eu não ia consegui uma pessoa que tivesse misericórdia de mim? Eu não consegui um advogado? Consegui gratuito... E ele foi muito advogado...". (...) Mas é assim, a gente faz as coisas, a gente tem que pensar, porque depois vem o retorno... Por isso que a gente tem que ser humilde, nada melhor que uma boa humildade! E como!

É uma batalha. O médico chegou a ponto de falar assim: "Você não tem necessidade disso, você pode muito bem trabalhar... Por que você anda atrás de um salário?". Eu falei:"Realmente, eu posso trabalhar, não nego pro senhor não... Eu já trabalhei até em casa de família... Agora o senhor precisa ver se a sociedade dá emprego...". "É, mas teve uma menina aqui que veio cancelar o prêmio aqui, porque ta trabalhando na fundação...". Eu falei: "Realmente ela arrumou emprego... E não só tem ela não, tem um monte trabalhando de telefonista... Agora o senhor pergunte: eu consegui? O senhor acha que se eu conseguisse um emprego, eu ia sair da minha casa quatro horas da manhã pra enfrentar fila aqui... Mas nunca doutor! Pelo um salário... No frio? Deixar de estar em minha casa pra vim atrás de um salário se eu não tivesse necessidade disso? Eu digo ter certeza que um dia que o dia, se o Senhor Deus um dia me arrumar um emprego, a primeira coisa que eu vou fazer é cancelar... Não é meu! É meu enquanto eu não to podendo... É meu! Mas se o senhor me der o 
emprego, eu venho cancelar...". Só quando você tem assim, vamos dizer, uma pessoa que esteja a fim de ajudar...

(...) Surgiu uma lei de cada empresa colocar um deficiente pra trabalhar, então já tem muito... Tem telefonista na Praia Grande, tem telefonista em Itanhaém, tem telefonista deficiente visual aqui na Fundação Luzia, no campo I, campo II. Tem na Santa Casa, tem na Osan... Graças a Deus tem muito! Só que eu não fiz esse curso ainda... E graças a Deus as vagas estão surgindo... Eu consegui uma vaga num dia desses aí, na praia Grande, de enrolar salgados... Mas o que acontece? Eles queriam me fichar, sem um mês experiência. Se eu fichasse eu tinha que abandonar o benefício. Eu pensei e falei: 'Olha! Eu não vou... Se eles não gostarem do meu serviço, vou cancelar meu benefício... Depois, ele não gostam do meu serviço, e aí eu vou ficar sem nada...". [O benefício] Pelo menos já dá pro aluguel, e eu vou esquentar a cabeça com outra coisa. Pelo menos o aluguel é garantido... E é assim!

(...) Eu não tive infância... A minha infância foi muito triste. Como a gente morava no norte, e o pessoal lá - para essas pessoas que têm deficiência, seja ela qual for - eles são assim muito cautelosos, eles não deixam... Mas eu, toda vida fui meio terrível... A única infância, que eu lembro, é que eu brincava com as minhas primas, e eu corria, mesmo sem enxergar. Mas a minha mãe pegava muito no meu pé. Quando tava só a minha mãe - meu pai trabalhava muito - ela ainda deixava eu brincar um pouquinho, mas quando o meu pai tava, eu não tinha liberdade porque ele me prendia demais. Era só dentro de casa... Então eu não sou aquela pessoa que teve infância que eu gostaria mais de ter. A infância que eu gostaria de ter eu não tive! A gente sempre foi pobre. Pra você ter idéia, nem boneca eu nunca tive... As minhas bonecas eram feitas de pano, a minha mãe fazia aquelas bruxinha... E eu além de tudo, eu não tinha minha irmã para brincar, eu só tinha irmão. Então aquilo me deixava muito triste... Quando eu ia brincar com as minhas bonequinhas, bruxinhas, era sozinha. Raramente aparecia uma colega pra gente brincar, às vezes elas vinham me buscar... Eu tinha uma prima que a gente brincava, mas ela era muito birrenta, brigava à toa. $E$ além de brigar ela pegava minhas coisas, tudo... A minha mãe fazia as roupinha das bonecas, tudo bonitinha, mas eu não enxergava, ela catava tudo... A minha mãe ficava irada de raiva. [Eu descobri] porque eu conheço tudo que eu tenho na minha casa e na minha vida... Quando eu ia arrumar as roupas da boneca, tava faltando aquele vestidinho, aquele paninho bordado, que minha mãe bordava e banhava; então tava faltando. Sem querer eu ia lá brincar com ela e eu via, pegava e eu via os vestidos da boneca lá. Às vezes, eu tinha umas colegas também que eram minhas amigas, que vinha me pegar pra brincar com ela, na casa dela. Essa não pegava [os vestidos das bonecas]. Era uma vizinha lá que era muito amiga da minha mãe; mas ela não pegava minhas coisas, no fim ela até fazia roupas pras minhas bonecas. Elas me davam muitas coisas... Mas a minha prima era fogo... Então eu não tive aquela infância assim... Depois elas foram namorando muito cedo e aí foram me esquecendo. E eu, como não tinha namorado, fiquei brincando de boneca até quase quatorze anos sozinha. Porque eu não tinha pra onde sair. Eu não tinha namorado. Então eu fiquei, depois eu enjoei das bonecas e não brinquei mais. Foi acabando a infância... Mas não teve assim aquela infância, que eu gostaria de ter...

A adolescência também, não foi muito boa... A adolescência foi pior ainda porque, já com dezoito anos, não tinha ninguém pra sair, ninguém queria andar comigo... A não ser as minhas tias. A minha mãe pouco saía e, outras pessoas assim, não 
andavam comigo porque... Na realidade a deficiência no Norte, nesses lugares dos interiores, qualquer tipo de deficiência... Hoje até que tá melhor, mas nem tanto... Mas ainda tem lugares pro interiorzão, que o deficiente ele é um tropeço na vida da família, dos irmãos, do pai, da mãe... Então eu era muito presa dentro de casa... Pra ser sincera, eu sou honesta, eu não tive, infância e nem adolescência. Foi muito triste! Tanto que eu, quando eu vim praqui, meu primeiro paquera, paquera mesmo, eu tava com trinta e dois anos. Meu primeiro namorado, que foi namorado mesmo, que me fez mulher, foi quando eu já não tava mais com a família, já tava pela minha conta, com trinta e oito anos.

[As pessoas fazem diferença pelo fato de ser deficiente]. Se for cego não, mas se não for, faz... Tanto que é muito difícil um homem se interessar por uma deficiente visual, ou uma mulher também se interessar por um deficiente visual. É difícil! E a gente mesmo, por causa do preconceito, a gente não quer... Eu não quero, e as minhas colegas que eu conheço, a maioria tudo se envolveram com deficientes visuais. (...) Mas a gente não se envolve com pessoas que enxergam, porque o preconceito é grande. Mesmo que ele se envolva, mas ele quer deixar a mulher em casa, não quer sair com ela. É muito raro, muito raro, os deficientes que a gente conhece, serem casados com pessoas que enxergam, tanto faz da parte do homem como da mulher.

Eu vim ser criança, jovem, adolescente, adulta, depois que eu dei um tapa na vida que levava e construí outra vida. Então, daí pra cá eu fui um tudo um pouco. Mas tudo mesmo... Eu vejo assim que a minha infância, a minha adolescência eu perdi... E isso me deixou assim muito triste... E eles [os irmãos] tinham um pouco de preconceito comigo, eles não andavam comigo... Agora não! Agora eles já andam comigo, porque eles viram que eu sou capaz, mas também não é muito a favor. Então essas coisas eu não tive. Essas coisas é o que me chateia muito...

[O tratamento] Só tinha em Salvador, mas era um local que você tinha que ir, você ficava o dia inteiro, mas a noite vinha embora... De cinco horas pra tarde, você vinha embora. Tanto que lá tem vários deficientes visuais que até hoje não sabe ler porque não moram na capital, moram no interior, no Nordeste mesmo. E entre o Nordeste pra capital é muito longe... São dois dias, três dias de viagem... $\mathrm{E}$, pra falta de recurso, como pra esse tipo de doença, deficiência, isso continua... Continua... (...) Tanto que a maioria das pessoas que moram lá, que tem família aqui, eles correm tudo para aqui; eles não vão pra Salvador, mesmo morando lá. Mas eles obrigam a vir pra aqui. Quando me viram, que eu voltei pra lá, quando viram com minhas próteses perguntaram onde eu tinha feito e eu falei: "Ah, eu fui pra casa dos meus irmãos, lá em Santos e eu fiz lá. Então daí pra cá... (...)". Sabe que uns trinta anos que eu fiz a cirurgia do meu olho, que eu uso prótese? Daí pra cá o pessoal começou tudo a vim tudo pra cá... A maioria hoje tá aqui. Tem aqueles que desistiram, outros vão pra lá, vem pra cá e voltam... Mas tem muita gente que era de lá e que tá aqui. Da Bahia mesmo eu conheço um monte que mora aqui e que fizeram toda a cirurgia aqui. Eu conheço um monte...

(...) No momento, os deficientes eles precisam de tudo. Principalmente apoio... A sociedade tem que apoiar mais, em todos tipos, nas situações do emprego, na situação do transporte, na situação da ajuda pra atravessar. [É] Uma barreira assim muito forte... Às vezes eu saio daqui - hoje é o dia que eu saio muito tarde do treino - então eu fico ali na avenida e às vezes eu chego à passar até meia hora implorando pra me atravessarem; o pessoal passa e finge que não vê, aí vem um filho de Deus e me atravessa. Os ônibus, tem o motorista já te conhece, mas se ele te vê no ponto sozinha ele não pára, ele vai embora... O emprego, eu acho que as firmas, as empresas, têm que abrir mais crédito pro deficiente 
trabalhar... Em primeiro lugar, o deficiente - tanto faz o visual, como o cadeirante - [precisa] ser mais visto na sociedade e a sociedade acreditar que a gente é capaz. E apoio da família, isso é muito importante, é o que eu não tive... Isso é muito importante! O apoio da família...

Em noventa e dois, eu tive uma amiga... Eles [irmãos] não queriam me dar apoio pra eu estudar e eu conheci essa amiga, que é amiga dos meus irmãos e das minhas cunhadas, e a gente se deu muito bem. Foi ela que batalhou, foi ela que veio aqui, falou com a diretora, me trouxe aqui, fiz a entrevista... Foi ela que arrumou a escola pra mim. (...) Eu vivi situações aqui nessa época muito difíceis. Porque foi quando eu resolvi morar definitivo aqui [na instituição], a diretora me cobrava muito porque a família não me dava apoio, eu não podia fazer nada. A diretora chamava atenção deles, tinham as reuniões, eles num vinham, depois ela me cobrava... Nossa! Foi um inferno naquela época! (...) Aí essa amiga tomou conta de mim e falou: "Olha! Eu vou assinar uma declaração... Eu vou fazer de conta que eu assumo ela. Nas reuniões, eu fico com ela...". (...) Eu precisava de estudar e eu optei pra eu ficar aqui, interna. Tinha as regras, tudo bem... (...) Eu passei acho que cinco anos sem vê-los [familiares]... (...) Mas, eles [familiares] começaram a magoar ela, falavam que ela tinha tomado conta de mim, tinha tirado eu da minha família. Ela falou assim: "Olha, eu não tirei, eu apenas quis dar um apoio, porque ela precisa estudar e vocês não quiseram apoiar ela em nada então... Eu acho que eu precisava fazer isto por alguém...". (...) Eu fiquei de mãos atadas... (...) Eu tive um sentimento assim, muito grande... Foi uma pessoa que me ajudou muito e ela acabou deixando a amizade tão bonita que a gente tinha...

(...) Em alguns termos, era pra mim ficar com eles [familiares] para ajudar. Eu fazia tudo na casa deles. Era cinco horas da manhã, eu já tava no tanque, lavava um pouco de roupa, a esposa dele saía pra trabalhar e ele também. Nove horas, eu terminava, eu ia fazer café pras crianças, acordar as crianças, dar banho, arrumar pra ir pra escola. Tinha uma menor que ficava comigo, quando era uma hora da tarde... Os outros saíam oito horas e estudavam das oito ao meio dia, saía dois e ficava uma menor comigo. Dez horas eu acordava a menor, dava café, trocava, dava banho, trocava pra arrumar, ela entrava uma hora no prézinho. Os outros chegavam, a vizinha ia levar a menor, que eu já tinha trocado pra ir pra escola, e os outros chegavam e iam almoçar. Eu tinha que dar almoço, quando eu terminava de dar almoço, eu ia arrumar a casa. Quando eu terminava de arrumar a casa, cinco horas a menor chegava, eu tinha que preparar o almoço pra menor... Então eu servi muito... (...) Eu tive que escolher... (...)

Se uma colega minha me chamasse pra passar o final de semana, eu tinha que sair daqui, porque se eu fosse pra casa eu não podia sair na rua: "Porque você não tem condições de sair sozinha, você vai lá não sei pra onde, pra São Vicente... Você não pode sair sozinha...". (...) Quando eu vim operar, minha sobrinha menor estava com dois mesinho de nascida, eu fazia mamadeira, eu trocava, dava banho. Eu operei a minha vista, o médico falou assim: "Olha... Você não pode pegar quentura, calor do fogo, você não pode pegar peso...". A minha vista tava com pontos. (...) São esses tipos de coisa que me deixa triste com a minha família.

Eu me sinto mais orgulhosa, nesse ponto... Porque dei um pulo na minha vida, onde muitos não têm coragem... Porque para o deficiente morar sozinho tem que ter coragem... Não é todo mundo que consegue morar sozinho! Porque chega 
muita coisa que apavora. Chega o medo... Você começa a pensar: "Se eu adoecer, quem vai cuidar de mim? Se acontecer de alguém entrar aqui e eu não ver, por quem eu vou chamar?". Então se passam muitas coisas pela cabeça, se você não for uma pessoa forte, você não mora sozinha. Eu acho que é vontade de viver...

Eu tenho colegas que às vezes quebram um copo ou uma xícara, e se tem um vizinho perto elas vão chamar o vizinho pra catar. Eu não! Eu vou de pé... Eu só faço faxina na minha casa descalça, pra sentir o chão, se o chão tá limpo. Tem problema, se quebra um prato e se espalha pela cozinha inteira, eu vou com confiança em Deus! Porque se cortar, paciência... Mas eu vou varrendo pra frente e vou passando o pé devagar onde tem vidro. Primeiro eu cato os maiores com a mão, depois eu vou juntando os pequenos num canto. Tanto que se cair e quebrar debaixo do fogão se cair, aí é duro pra catar. Mas eu vou tentando, até catar tudo... Muitos vão chamar o vizinho pra catar: "Ai! Quebrou um prato ali na minha casa, você pode pegar os vidros?" Eu não faço isto!

Hoje em dia o meu problema é mais com a situação financeira. Só isso! Se o que eu ganhasse fosse um pouquinho a mais, já é o bastante. , porque Deus... Deus [...] guardado minha super casinha. [Os outros deficientes são] alguns assim, alguns não... Às vezes tem um deficiente visual que até não ganha tão mal, não paga aluguel, mora num apartamento... Mas o que acontece? Ele precisa, porque a família suga. Eu não! Eu, ninguém me suga. Agora é só eu mesmo! Eu ganho um salário, o benefício do LOAS hoje. Esse benefício serve pra mim pagar o aluguel, então eu vivo duma ajuda minúscula e cem reais que uma amiga minha me dá todo mês e às vezes roupa, porque ela me supre. Então se não fosse ela, eu não ia morar aqui. Não tem condição! O lado que aqui a escola também colabora com uma cesta básica pra mim... Se tivesse condições de pagar um aluguel, eu tivesse outra vida, e esse benefício do LOAS fosse só pro meu gasto, tava maravilha! Só com as forças de Deus eu vou até o final, mas nem por isto eu reclamo não...

Agora mesmo, ali, eu já achei encomenda de três quilos de sequilho, e eu vou fazer.

Ajuda... Agora mesmo eu vou fazer... (...) No momento o que acho que é o problema de nós todos, é essa pressão; mas, pelo seguinte, porque as coisas são muito caras... Você recebe pouco, você tem uma conta daqui pra pagar, tem outra dali pra pagar, e você acaba por pagar tudo. E eu sou assim, eu não gosto de ficar devendo. Por exemplo, eu recebo meu salário, pago o aluguel, pago o que eu tenho que pagar. Enquanto eu não elimino todas as minhas contas eu não compro nada pra casa. Se sobrar, eu compro, se não sobrar...

[Isso é] Pra todo mundo! [Mas para o deficiente] É pior pelo seguinte: porque você não arruma emprego... Se você arrumasse assim um emprego, pra você ganhar nem que fosse menos de meio de um salário... Se você ganhasse assim, pelo menos uns duzentos reais, já dava uma boa aliviada. Agora, quando você mora com a família, e a família que é a sua procuradora e vai tirar seu dinheiro do banco e do banco você não vê nada, aí é pior do que eu... E acontece... Aqui mesmo, aqui dentro é cheio... Aqui dentro é cheio de gente que tá morando com a família e vai lá, tira o dinheiro, compra o que tem que comprar pra ela e o resto embolsa... Tem um senhora aqui que vende bala pra sobreviver, mas ela tem mais de oitenta anos, ela não merecia isto; está doente, mas a família não cuida... São por essas e outras que eu não quero a minha família perto de mim... 
E tem outra coisa... Eu lutei muito pra chegar aonde eu cheguei... Eu lutei muito! Eu perdi muitas noites de sono, eu chorei muito. Acho que eu chorei o que eu não tenho mais que chorar... É por isto que eu não abro mão dos meus direitos pra ninguém. Pra ninguém... Sem exceção! Só pra Deus... É o único que eu abro mão dos meus direito... Mas dos mais, da terra, ninguém...

Eu fui a várias reuniões, que tinham as pessoas que esclareciam [sobre os direitos]. Eu ia a reuniões da prefeitura, de vereadores... Agora que eu dei um tempo... Aqui eles ensinam muito, a assistente social chama a gente, conversa... E outra, quando eu comecei a ler, eu buscava... Eu me interessava muito por leitura... Então eu pegava livros, ia lendo, e ali eu via onde você tinha direito e onde você não tinha...

Mas mais foram reuniões... Eu assisti muitas reuniões. Toda vez que tinha reunião na câmara, o pessoal vinha me falar: "Ah! Vai tem reunião tal dia...", eu ia direto pra lá... Tem certos tipos de direitos que você até que deixa passar... Por exemplo, às vezes eu chego no ônibus, aquelas poltronas ali da frente estão tudo ocupadas... Um chega e olha pra mim, outro chega e olha pra mim... Aí fica um jogo: "Ah! Porque esse banco aí é de deficiente...". "Ah! Porque vocês não sabem...". "Ah gente! Não briga! Eu não ligo!". Então, quando eu acho uma pessoa: "Senta aqui, Dona!", eu vou e sento... Quando eu não acho, eu vou de pé. Eu não ligo muito! Agora se é uma coisa que vai tirar o direito de eu viver, se é uma coisa que vai tirar o direito de eu crescer... Ah não gente! Aí vai ser diferente. Vou brigar mesmo!

Porque eu tenho certeza que se eu for morar com a minha família, vai ser a mesma coisa... Não, eu não quero! Não quero! Eu vou morar sozinha. Enquanto eu puder pagar isto aqui, eu vou morar sozinha... Tem vezes que dá desespero... Essa semana mesmo eu tava muito cansada: é você que tem que limpar a casa, é você que tem que fazer a comida, é você que tem que pagar a conta da água, você tem que pagar a conta da luz, você tem que ir no mercado... Chega uma hora que você acaba ficando estressada... Depois que tudo está no lugar, você diz: "Ah! A minha liberdade é tão bom!". Eu chego na minha casa, eu durmo a hora que eu quero, eu levanto a hora que eu quero, faço o que eu quiser... É por isso que é tão bom! Eu sofri muito pra chegar até aqui, chegar onde eu cheguei... Quando eu decidi a morar sozinha, nossa! O mundo caiu na minha cabeça... "Você é louca? Você vai morar sozinha?". Eu: "Vou!". Tem uma amiga minha falou: "Não, você não vai morar sozinha...". "Eu vou. Quem falou que eu não vou? Eu vou e eu vou me dar bem, você vai ver...". O que foi que ela fez? Ela foi lá no meu médico e falou: "Doutor, essa menina é louca!". "Por que?". "Porque ela decidiu que agora vai morar sozinha, tá procurando casa. O que o senhor acha?". Ele falou assim: "Olha, eu não vejo nada de mais... A única coisa que pode acontecer é ela ão se dar bem e querer voltar e por causa de estar sozinha... Mas eu não vejo nada de mais... Se ela quiser, boa sorte!". Eu tô há acho que nove anos morando sozinha...

(...) Quando o meu pai decidiu que ia me mandar pra cá, não tinha mais o que fazer... Só foi pra extrair a vista mesmo. Depois eu aprendi a ler... Muitas pessoas que vem para aqui têm aula de AVD, porque eles perderam a visão depois e fica complicado de fazer as coisas, então as professoras ensinam à lavar, passar, arrumar uma cama... Eu não. Eu não participei dessas aulas... Eu já sabia, porque a minha mãe me ensinou e eu era muito curiosa...

Tem grande diferença [entre deficiência congênita e adquirida]. Principalmente para aqueles cegos que não viram antes, eles tem mais segurança em tudo... Às 
vezes eu vou na piscina com uma das minhas colegas que não enxerga, mas que ela perdeu bem depois; eu tenho certeza que eu não to indo no caminho errado, mas ela vai comigo, pegando na minha mochila, ou mesmo no meu ombro, ou até assim de mão dada, mas ela fica insegura. Ela só vai com segurança se uma das inspetoras for. (...) Então tem grande diferença pra quem já teve e pra quem nunca teve [visão]... Porque quem nunca teve, ele nunca viu, ele não tem medo de obstáculo. Ele caiu, mas ele fala assim: "Ah! Eu nunca vi mesmo, eu caí, mas eu vou levantar!". Mas quem já viu... Se eu disser assim: "Ah, cuidado! Que ali tem um carro!". Pronto! Ele empaca ali e ninguém tira.

[A cidade de Santos] Das que eu já conheci, é a melhor, mesmo complicada. Mesmo com as calçadas quebradas, mesmo a moça que tem dificuldade em atravessar... Pra mim - e todos os deficientes visuais falam - é a cidade melhor para um deficiente visual. É Santos... Humaitá é péssimo... Cubatão é péssimo... São Vicente é uma desgraça... O lugarzinho terrível pra deficiente visual andar... Eles não têm uma linha guia em nada, é tudo no meio da rua. A linha guia das calçadas são uns sacos enormes, cheio de pedras, cheio de árvore nas calçadas, cheio de entulho. E aqui não. Aqui é uma coisa que é quebrado, mas tem a parede pra proteger... Sossegado... Sossegado... Dos lugares mesmo, a que eu achei pior foi São Vicente. Todo mundo fala dessa cidade... É a primeira cidade da baixada santista, já devia estar bem adiantado, mas tá bem atrasado... Eu já morei ali, é um inferno!

(...) Vinha de ônibus [de São Vicente], todo dia. Eu acordava três horas da manhã, levantava, fazia café... Eu fui uma maluca... Eu me envolvi com um cara e a gente morou aí... Depois que a gente se separou, ficou um tempo separado, depois a gente voltou de novo... Ele veio, e começou aquelas coisas: "Ah! Porque lá o aluguel era mais barato, a casa é maior e a gente polpa pra comprar um terreno... Que lá não sei o quê...". Mas você sabe: mulher tem horas que ela é meio maluca... Mulher é mais cega do que ela pode imaginar! E eu acabei indo, caí na dele e acabei indo... Não deu certo de novo, passei uns quatro meses ainda morando com ele, mas não deu certo, e eu parei definitivo. Eu levantava três horas da manhã, fazia café, a gente tomava café, depois ia tomar banho pra seis horas da manhã sair. O ponto era longe, tudo é longe... Para oito horas estar aqui... Eu fiquei um trapo! A gente saía daqui cinco horas da tarde, chegava lá oito horas da noite, pra fazer janta, pra jantar, pra dormir... Pra no outro dia fazer a mesma coisa... Muito puxado! Eu tava fazendo telecurso, abri mão, porque eu não tava dando conta de sono. Não conseguia... Vinha o final de semana, tinha casa pra limpar, um monte de roupa da semana inteira pra lavar... Nossa! (...)

[A deficiência para homens e mulheres] Eu acho que é a mesma coisa, tanto faz... Tem homem destemido e tem homem frouxo... E tem homem que reclama muito, como tem mulher também que reclama muito. Tem homem que ele mora sozinho, não liga de fazer nada e vai em busca dos seus objetivos. Já tem outros que ficam reclamando: "Ah, porque comigo acontece isso, porque comigo acontece aquilo, porque eu não tenho isso, porque eu não tenho aquilo...". Então só reclama... E não sai do lugar... Eu acho que acontece a mesma coisa, tanto faz como na parte do masculino como feminino como vice-versa.

Eu acho que ainda a sociedade precisa aprender a trabalhar mais e mais com o deficiente. De tipo qualquer, tanto o visual quanto o paraplégico. $E$ a gente ainda tem muita dificuldade na rua. A sociedade hoje só não está mais péssima ainda, por causa da escola, principalmente a escola aqui... Porque, se existe uma escola que luta pelo deficiente visual... Eles num dão moleza pro deficiente visual, mas 
em compensação eles lutam muito; o que depender deles, pra fazer por a gente... O objetivo deles é que a gente saia pra batalha e que consiga. Só que ultimamente tem entrado muitos que vai ser difícil, porque eles não têm coragem, principalmente esses que perderam depois... Eles num tem coragem... Eu conheço muitos aqui que se vão morar sozinho, eles vão entrar em "parafuso".

Esse ano eu entrei em depressão... Nas férias, eu fiquei num dilema que eu acordava, fazia um pouco de café, tomava e sentava no sofá e não saía mais... Eu falei: "Não! Isto não é a Fátima que eu conheço, o que que é isso? Deus me livre!". Aí eu fui pro médico, já liguei pra minha amiga e falei: "Preciso dum médico! Eu tô péssima!". Eu não tinha condições de fazer nada. Eu levantava, assistia televisão, aquela desgraceira toda que teve no mundo de chuva, de tempestade, de terremoto... Eu assistia televisão, quando eu via a chuva cair, pronto! Aquilo ali me acabava, acabava o meu mundo... (...) Tinha uma vizinha que começou a me tirar de casa, uma vizinha que trabalhou aqui; ela soube, me tirou de dentro de casa esses dias... Eu marquei uma consulta com o médico, cheguei lá e contei tudo o que tava acontecendo... Ele falou assim: "Filha! Depressão é um buraco. Mas se você não se ajudar, você não sai dela. Você tem que sair! Eu vou passar umas cápsulas pra você... Você vai mandar fazer trinta cápsulas e vai tomar... Se você não melhorar, vem aqui. Se melhorar... Mas tenta sair!". Comecei a tomar, com dois dias que eu tava tomando, eu já comecei a sentir diferença... Quando foi na outra semana, já tinha oito dias que eu tava tomando esse remédio, levantei com uma disposição... Levantei cedo, fiz um faxinasso na minha casa, falei: "Agora assim, agora é a Fátima!". Voltei de vez... Eu liguei o rádio... Nem rádio eu tava ligando! Comecei a assistir música e ouvir os hinos, porque eu gosto de ouvir muito música de louvores, porque eu sou evangélica. Eu só sei que eu fiz um faxinasso na casa de cima até embaixo... Aí pronto, a minha vida firmou de novo... Eu tinha medo de sair sozinha. Eu não queria ficar em casa e nem queria sair... (...)

Eu tenho um problema muito sério comigo... Não vejo problema... Acho que é respeito que você deve a Deus e a natureza: eu tenho muito medo de raio... Eu tenho pavor. Quando eu mexo no rádio que eu escuto um trovão, nossa! Pra mim não existe uma coisa pra ter mais medo do que isso. Se dá um trovão eu já desligo tudo na minha casa, já fecho tudo... Pode estar o maior calor, tudo fechado... Só abro as portas quando aquilo acalma... Eu acho que foi isso também. Foi muito raio... Então eu vivia assim, assustada! Porque eu nunca tinha visto desse jeito, todo dia... Eu acho que também eu fiquei assustada por isto... Depois tinha muita gente aqui e nas férias eu me deparei sozinha... Ajuntou uma coisa com a outra... O médico falou pra mim: "Olha, também é um pouco da menopausa. Tem mulheres que não tem depressão, mas tem outras que tem...". Mas graças a Deus, eu superei, estou viva, graças a Deus...

Eu acho que Deus dá um tipo de deficiência a uma pessoa que tem uma prova que não deve, e às vezes a pessoa reconhece o amor Dele por nós. No médico, eles falam que são coisas genéticas, problema do pai e da mãe, que transparecem no sexo... Mas muitas das vezes, Deus escreve certo com você... Porque é assim: se você tem uma deficiência ou qualquer tipo de problema, e você se revolta contra Deus, é pior ainda... Então você busca - é a minha opinião - aquela força Nele, e você encontra... Quando eu era mais nova, eu não entendia a palavra de Deus... Eu cheguei até o ponto de pedir que Deus me levasse. Agora não! Se eu estou aqui, é porque algum propósito o Senhor tem na minha vida. E nada acontece por um acaso! Eu ainda creio que Deus tem algum propósito na minha vida, seja ele qual for... Pode ser que eu ainda vá ser uma pessoa infeliz, e pode ser que eu ainda vá ser uma pessoa mais feliz do que sou... Então por isto 
que eu não reclamo, não me revolto, e eu vejo assim... Se Deus deu seu filho pra morrer pelo mundo inteiro, pela humanidade, porque nós também não podemos carregar nossa cruz numa boa? Eu não reclamo não. Pra mim, a deficiência é assim...

Aqui tinha uma igreja evangélica aqui e tinha uma professora que era da igreja... Ela era minha professora de braile, porque me alfabetizou. Ela um dia me chamou: "Ah! Vamos na igreja?". Não que eu fosse aquela mundana depravada, mas eu não ligava... Depois, eu comecei a ir e gostei dos cultos. Um dia, eu falei assim: "Ai Senhor, se um dia eu for evangélica, eu quero freqüentar igreja...". Um dia eu ia, outro dia eu não ia; e passava três, quatros meses que eu não ia, passava uma semana que eu não ia... Foi quando eu saí de lá e andei dando umas cabeçadas erradas... Foi quando eu conheci esse rapaz que não enxerga também, a gente começou a namorar, depois a gente começou à ter relações mais profundas, namoramos dois anos, quase nos casamos, depois ele me largou, eu larguei... Eu fiquei sabendo que ele tava com outra e eu não admito traição... (...) E foi aí também quando eu fiquei um pouco depressiva, fiz um pouco de psicologia, terapia, tudo... Depois eu falei: "Ah! Depressão a gente é que sai...". Eu num fui mais na terapia, comecei minha normal de novo... Eu falei assim: "Ah! Quando eu tava numa boa, saindo pros lugares da vida, eu nunca pensei em Deus. Agora que eu tô depressiva, agora eu num vou... Vou deixar melhorar...". Quando eu já tava mais cabeça fria, eu comecei à visitar de novo [a igreja] e resolvi aceitar. Já tem dez anos que eu sou Cristã. E daí, eu fui compreendendo as coisas cada vez mais...

Se eu não me revoltava com a deficiência, agora que eu não me revolto mesmo... Porque Deus é maravilhoso! Ele tem feito tantas coisas na minha vida... (...) É por isto que eu digo, nada acontece por um acaso, e Deus tem um propósito na nossa vida de todos nós... O Senhor tem um propósito! E eu busco e acredito, e ele tem me dado prova que ele é Deus... Essa força não busco em ninguém, nem em mim mesmo... Eu busco em Deus! Eu sempre falo pras minhas colegas: "Gente! Entrega tudo nas mãos de Deus, deixa que ele age... Deixa que Deus age por nós...".

(...) Eu faço algumas coisas [na instituição]... Informática, coral, hidroginástica, educação física, jogo nos campeonatos... Eles que escolheram... Eu só tenho uma coisa que eu já pedi pra sair e eles não deixaram que é só o coral. Eu quis sair, e eles falam que não, que eu desse mais um tempo; eu vou tentar. Já pedi duas vezes, mas eles não querem me liberar, não sei por que não... As outras atividades, eles põem e perguntam se eu posso ir em tal aula... Se puder trocar, eles trocam; se não puder, fica sem... A única coisa que eu ainda queria voltar, dar uma repassada era na culinária, mas não está tendo; a piscina eu pedi, por causa de uns problemas de saúde, eu acho muito importante... [Venho] Todo o dia, de segunda à sexta. Só que tens uns dias que eu saio cedo; o dia que eu saio mais tarde é oito, por causa do treino, mas na sexta eu saio depois do almoço, terça feira eu saio quatro horas, quinta feira eu saio duas horas. É, é isso!

Eu acho assim, quem tem a oportunidade de estudar e quem ainda tem paciência, quanto mais que você estudar melhor. Eu não posso estudar porque, primeiro: eu tenho a minha casa, a minha casa precisa um pouco de mim e, eu não tenho mais paciência pra estudar. Eu vou fazendo umas atividades, mas não tem assim mais aquela... Se eu fosso mais nova... O que eu queria mesmo, na realidade, eu não consegui: estudar pra música, que eu gosto, ou então trabalhar em alguma cozinha, pra fazer receitas. Essa se eu pudesse, se eu fosse 
mais jovem, eu ia fazer. Eu ia cursar uma faculdade de nutricionista e uma faculdade de música. Infelizmente agora, nessa altura do campeonato, eu não vou mais... Eu penso assim! Essas pessoas que são jovens, eu acho que eles nunca deveriam desistir dos estudos... Se pudesse fazer todos os tipos de curso, todas as faculdades... Tem gente aí que tem capacidade para isso... É chato? Não vou dizer que não é chato, mas é bom. Eu, quando eu fiz o primeiro grau, eu morava com a família em São Vicente, mas eu ajudava muito na casa, então eu ficava assim um pouco carregada de lição. No supletivo existe muita lição, e aí eu fui perdendo assim o pique, ficando cansada, fui ficando estressada, a cabeça já não estava mais funcionando, eu abandonei... Depois eu tentei aquele no Telecurso, mas aí eu já tinha a minha casa, eu já estava morando sozinha, falei: "Ah, Não! Já não dá mais!". Eu vou eliminando as provas. Quando dá, quando tem prova, eu faço... [Para fazer a prova] Eles põem braile e dá um a tinta. A tinta é pra professora que vai ler a prova ficar. E o braile é pra a pessoa que tem o problema de deficiência. ..

[Na época da escola] Foi junto com todos. Ali foi muito sofrimento porque tinha muito preconceito. Não tinha uma professora adequada pra gente, não tinha uma professora de reforço. Colocaram uma lá que ainda não sabia o braile direito, e tinha outra que já sabia, que era formada; mas quando era a que tava começando a aprender o braile, ficou muito difícil... E às vezes, na classe, você pedia para ajudar e o pessoal não queria ajudar e a professora não tinha tempo e ia passando matéria. Então foi muito difícil! Eu trazia e ia estudar no banco da praia, com a professora de reforço, que é baixa visão, mas que conhece o braile e que hoje é minha amiga. Foi muito difícil! Da terceira série até a oitava, foi super difícil, mas eu concluí... E tinha [outras pessoas com deficiência na classe $]. .$.

Eu cheguei a tempos que eu pensei que eu tinha [deficiência intelectual], por incrível que pareça! Quando eu vim pra aqui, como já te falei, eu tinha muitos problemas com a família; eu queria estudar, só que eles não queriam me dar apoio... Eu fiz uma locomoção quase que forçada, eu pedi pra me colocar, só que como eu não tinha noção de rua, eu não entendia e eu achava que eu tinha problema mental... Eu marquei um neurologista pra mim, mas sem professora saber. Eu fui lá e contei a situação: eu tinha muita dificuldade em andar na rua. Não sabia o que era uma esquina, não sabia onde eu ia parar para atravessar, não tinha noção quando virava, quando virava a esquerda, a direita... Ele perguntou onde eu morava, eu falei, perguntou com quanto tempo eu comecei a estudar, eu falei. Ele falou assim: "Mas escuta, você acha que você tem problema mental?". Eu falei: "Acho! Eu acho, doutor, porque faz tanto tempo... Eu passei quatro anos na locomoção, eu já quis sair e a professora não deixou...". Ele falou assim: "Quem te pediu estes exames?". Eu falei: "Ninguém!". Ele falou: "Como ninguém?". Eu falei: "Não, estou fazendo por minha conta.". Ele falou: "E o que você acha?". Eu falei: "Eu acho que eu tenho um problema mental...". Ele falou assim: "Você faz algo em casa?", eu falei que fazia tudo. Ele falou: "Você acha que quem tem problema mental faz tudo?", falei: "Acho!". Uma professora daqui foi comigo, o médico perguntou assim: "O que você acha?". Ela falou: "Loucura da cabeça dela... Ela não tem problema mental nenhum.". Ele falou: "Eu também acho... Eu acho que quem tem problema mental, não tem as atitudes que ela tem, e o jeito é diferente...". Eu falei: "Mas eu quero fazer o exame...". Ele falou: "Não! Eu não vou fazer porque não vejo nenhuma necessidade...". Eu falei: "Não! Mas eu quero sim. Eu tenho certeza que eu sou louca. Eu não aprendo!". Ele falou assim: "Fátima, põe uma coisa em sua cabeça, você nunca conheceu uma cidade, Santos é uma cidade grande, e você veio pra aqui com vinte e nove anos. Você acha que você tinha 
condições de entrar em uma locomoção pra ir na rua e já querer aprender? Eu acho até que você é uma pessoa valente. Nossa! Eu acho que no seu lugar, sem nunca ter conhecido a cidade, eu nunca iria sair assim...". Eu falei: "É, mas a necessidade obriga, né?". Ele falou assim: "Olha, eu acho que não devo fazer os exames...". Eu falei: "Não! Eu acho que devo sim.". Falou: "Ah Ta bom! Vamos fazer para tirar as conclusões aí. Você quer fazer, nós vamos fazer.". Marcou o exame, eu fiz...

(...) Fui receber os resultados; naquela época o resultado era um processo demorado... Com um mês eu fui receber os resultado. Ele falou assim: "Pronto Fátima, aqui está o resultado dos exames. Não tem nada.". "Eu não acredito, doutor! Não é melhor repetir?". Ele: "Pelo amor de Deus! Pára com isso! Não, mas eu quero saber quem the pediu esse exame? Eu acho que quem the pediu esses exames é mais louco...". Eu falei: "Não! Mas foi eu mesmo...". "E a professora está? Eu gostaria de falar com ela.". Eu falei: "Não, mas ela não sabe, doutor.". Ele falou: "Olha, não deu nada.", e leu todo o exame também. Eu cheguei nele e falei: "Então eu vou sair da locomoção, né doutor?". Ele falou: "Tenta! Eu acho que "você não deve sair da locomoção". (...) Pra mim foi [difícil]...

Eu cheguei nela [professora] e já falei: "Eu fiz o exame...". E ela: "Que exame?". Eu falei: "O exame de cabeça.". Nossa! Ela ficou brava... (...) Chamou a diretora: "Você sabe o que essa maluca foi fazer? Ela foi fazer um exame de cabeça! Ela acha que ela é louca!". Eu mostrei o resultado para ela, a diretora falou: "Fátima, pára com isso! Pára com essa bobagem! Você não nasceu na cidade, você se criou no mato, no Nordeste!". Eu falei: "Ah! Mas eu estou demorando pra concluir...". (...) Mas eu estava sendo forçada a fazer isso, a minha família me cobrava muito, queria que por que queria que eu saísse, que eu terminasse logo, podendo ou não. Minha professora foi muito boa, foi uma psicóloga. Nossa! Eu devo muito isso a Deus e a ela. Eu falei: "Bom, então o seguinte, nós vamos terminar esse ano, se eu não terminar, o ano que vem, não concluir, vou sair...". Ela falou: "Olha é o seguinte, se você terminar este ano, você acabou. Sem ano que vem... Se você não terminar, você vai ficar... Agora quem ta dizendo sou eu. Você vai ficar até quando eu quiser... Porque eu sei que você tem lentidão. Lentidão é uma coisa, problema mental é outra. A sua memória não ta mais captando o que é pra ser captado... Se você tivesse vindo até mais jovem... As meninas que entraram aí igual a você já concluíram. Mas por quê? Porque elas são meninas jovens, já chegam da cidade, conhecem o que é uma esquina, conhecem o que é uma rua paralela, conhecem o que é uma rua diagonal, conhece o que é uma rua de esquina, que faz e vai virando... É o seguinte: se ela concluir ela vai ficar. Ela vai sair se ela concluir. Se ela não concluir ela vai ficar e eu vou dar aula para ela o tempo que for...". A diretora falou: "Tem todo o meu apoio.". Levou mais de um ano, conclui com quatro anos, já estava desesperada. Depois eu fui me conformando, que era mesmo, pus a cabeça no lugar.

Fez quatro anos eu terminei. Graças a Deus eu vou pra todo lugar... Já fui pra Bahia duas vezes sozinha! Agora eu vou de novo! Eu fiquei com medo. Eu falava pra Deus: "Por que todo mundo conclui, menos eu?". Dois, três anos depois da locomoção, todas as pessoas entravam por último terminavam. Ela [professora] falava assim: "Você tem que se importar com você! Esquece os outros! Esquece os outros!". Mas mesmo assim, ainda tem algumas aulas que eu não fui. Por exemplo, era para ir na escada rolante, eu não fui porque eu fiquei com medo. Quando era a última aula que era para ir ao correio, na escada rolante, ela [a professora] foi embora... Essa eu não fiz... Tanto que eu não ando de escada 
rolante, porque eu já tomei dois tombos; os seguranças que estavam comigo, mas me deixaram cair. Eu fiquei com trauma daquilo ali. Eu não vou...

É muito difícil quando está chovendo. Mas isso não é só pra mim, é pra todos os deficientes, é muito difícil andar com chuva. Chuva e vento... O sol não, o sol colabora muito, mas a chuva e o vento atrapalham demais, porque você não escuta a barulho da rua. Se você escuta o barulho da rua, você tem noção de onde você está; se você não ouve a rua, se você não ouve o carro, de onde ele vem, de onde ele está saindo, pra onde ele vai, você só vê água, só escuta barulho de água, você não tem noção de nada... Quando você pensa que está encostada num muro, você já está saindo na rua... Então é horrível... Até dentro de casa, se você não for uma pessoa que tem uma boa percepção, com muita chuva você se perde. Eu não saio... Eu acho muito difícil e não é só eu que falo, todo mundo fala que a rua com chuva, é horrível de andar... É horrível! Chuva e vento. Vento porque também tira a noção; aquele vento batendo na sua orelha te tira a noção... E a chuva, além do barulho, tira também a noção também do caminho, como está cheio d`água, você acha que você está no lugar certo e você não está... Você não tem noção de onde você está!

(...) Santos é uma cidade muito boa pra viver pro deficiente, todo o deficiente gosta muito daqui. Os deficientes que eu conheço - e eu conheço vários - todos falam que não tem nenhuma cidade tão gostosa pra andar que nem Santos. (...) São Paulo eu não suporto! Não vou nem sozinha... Sempre que eu tenho que ir lá, vai uma pessoa comigo. Porque eu gosto daquele lugar pra entrar e sair, no mesmo da hora. Não gosto daquele lugar... É horrível também...

$\mathrm{Na}$ assistência da saúde, eu sofri mais quando eu tava com meu pai, porque meu pai é muito desinteressado pelos filhos. Ele cuida dele... Se ele sentir uma unha doendo, ele vai no médico, ele marca uma consulta e vai... Mas assim, em relação à família, seja a mulher e os filhos, não. Agora aqui, depois que eu estou aqui, eu não encontrei [dificuldades]... Eu só tive dificuldade na operação; nem tanto pra operar, mas pra colocar as prótese. Agora assim, do dia-a-dia, por exemplo, um quadro ginecológico, clínico, eu não tenho dificuldade. Eu não tenho porque, graças a Deus os meus médicos que eu pego são pessoas compreensíveis.

Já peguei um que a gente até discutiu, porque eu tive uns miomas e sem consultar outros médicos, ele queria que eu tirasse meu útero. Eu falei que não ia tirar. Ele falou assim: "Então se você não está satisfeita, a porta da rua é a serventia da casa...". Eu falei: "Realmente! Eu vou porque pelo que eu to percebendo você não concluiu a faculdade... Você não cursou, você comprou o diploma... Porque uma pessoa, você pede um exame, tem um mioma, você pode falar assim: Olha a gente vai ver o que pode fazer, vamos dar um remédio para diminuir... Não, você já quer operar? A minha menstruação não tem nem noção de quando vai parar...". Eu falei: "Não! Eu não vou operar. Primeiro eu vou consultar outros médicos...". Ele ficou muito puto... Eu também não deixei por menos, porque eu falei assim: "Ah, doutor é o seguinte, eu antigamente, eu era muito burra em lei, só que hoje em dia eu conheço das lei... Não é assim! Não pensa que você está pegando qualquer um... Eu conheço das lei... Eu posso ir em outros médicos, mostrar os exames e ver o ue eles falam...". Ele falou: "Você é muito boca dura...". Eu falei: "E o senhor é muito ignorante!". Ele falou pra eu me retirar da sala. Eu falei: "Com certeza! E tem mais... Se você for o único médico da face da terra, eu fico sem uma consulta...". (...) Eu peguei o exame e levei para outra médica, que eu tinha, ela falou a mesma coisa. Aí foi quando eu marquei consulta com o que hoje é meu médico há mais de dez anos, 
ele olhou os exames e falou: "Não...". Eu falei: "Doutor, isso aqui precisa operar?". Ele falou: "Mas operar pra que? Isso aqui vai acabar logo... Fátima, não fica apavorada que isso acaba...". Passei mais um ano, dois anos, foi quando a menstruação acabou, eu pedi de novo [exames], aí não tinha mais... E o cara queria que eu operasse. Eu não operei! Daí pra cá ele passou a ser o meu médico, ele é muito bom por sinal... Muito, muito bom... Se ele passasse e eu tivesse sentada, ele me chamava. Eu falava: "Doutor...". Eles falavam: "Você sabe que você tem prioridade...".

Quando eles [os olhos] estão muito, como hoje eles estão, saindo aquela lágrima, eu passo com o doutor Moreira... Ele dá aquela olhadinha, passa lá a pomada, um colírio. Acontece mais no verão, por causa assim de que o tempo está muito seco, com muita poluição, aí acontece. No inverno não, no inverno é uma beleza... Mas no calor esquenta e dá muita lágrima seca, o olho fica ressecado... Sempre os médicos eram de Santos... Só que quando eu vou polir as prótese - que eu tenho que polir de seis em seis meses - antigamente a gente ia pra São Paulo. Mas ficou um custo muito caro pra gente: sessenta reais pra polir a prótese, não sei quantos de passagem, e às vezes leva o dia inteiro. Aí eles resolveram tirar por aqui, só que assim, tem que ter muita gente, pelo menos dez pessoas... (...) Isso é pago. Acho que há uns três ou quatro anos que eu fiz, era trinta reais cada, sessenta reais o par... Um gasto... Não sei se já aumentou o preço, não sei...

Compreensão da sociedade é muito bom... Certo que têm alguns deficientes que gostam de ser paparicados, gostam de chamar atenção... Só que a gente conhece aqueles que gostam de ser paparicados e os que não gosta, os que pedem ajuda por necessidade e outros pedem ajuda para serem paparicados... Por exemplo aqui nós temos um professor de locomoção que dá aula para vários alunos aqui. Só que o que acontece? Aqui tem inspetoras, então os alunos ficam encostados nas inspetoras... Já moram com a família e a família não deixa fazer nada... Alias isso é um erro muito grande! Já começa a começar a agir é na família; a família tem que deixar o deficiente se soltar, fazer tudo, com prejuízo ou não. Já vai encarando o prejuízo... Pode quebrar um prato numa casa, pode ficar sem copo numa casa, porque vai quebrar mesmo - principalmente pessoas que perderam depois, eles ficam meio desnorteados - mas a família precisa deixar fazer. Porque se a família não deixar fazer as coisas em casa, lavar um prato, lavar uma louça, arrumar uma cama, fazer uma comida, vai pastar lá fora... Então tem que fazer... Aí o que acontece? A família não deixa, chega aqui, faz a locomoção, mas mesmo assim não sai do auxílio da inspetora. Aí pronto, fica um deficiente inútil! Então eu acho que isso tem que acabar, a família tem que deixar fazer...

(...) São essas coisas que a família precisa deixar fazer, a família precisa incentivar, e o Lar aqui também precisa incentivar mais ainda, porque vai ser muito pior lá fora ou com outra pessoa. Por exemplo, eu moro sozinha, no momento eu to precisando de alguém pra morar comigo porque as despesas estão muito altas, mas o que acontece? Eu prefiro morar sozinha e pagar caro do que dividir, arrumar uma pessoa pra morar comigo. Por que? Eu vou fazer as coisas dentro de casa e ela vai se encostar em mim, e eu não quero, porque eu sou cega também. Se ela se queima na hora de fazer o almoço, eu também me queimo; se ela derrama uma coisa no chão e suja, eu também. Quantos cafés eu não já fiz e não já derramou? Em cima da pia, no chão, em cima do fogão. Mas eu não vou desistir, eu preciso! Então a gente sabe: tem o deficiente que tem dificuldade e que precisa de ajuda e o deficiente que é folgado. 
Olha, pra ser sincera aqui mesmo - não querendo se gabar - pra ser pessoas valentes mesmo, pra ir em busca de seus objetivos aqui dentro, fora os homens, de mulher mesmo é só eu e Esther, uma menina que vende bala aqui fora. E de homem tem alguns, mas muito pouco, mas já têm alguns que luta mais pra ser independente... Mas o resto que tem aqui, eu não sei se é por causa da idade ou insegurança, eles não lutam não... Você já deve ter percebido que colocaram aquele tapete ali no chão pra ir de uma sala à outra, porque eles estão encontrando muita dificuldade de ir pra sua sala, pra suas aulas na hora de tocar o sinal. Não adiantou nada, continua na mesma... Eu não. Eu não eu não treino naquilo não. Porque eu não tenho paciência de procurar aquele negócio. Isso não é certo!

Isso precisa acabar... Primeiro já começando pela família: tem que incentivar a fazer, dando prejuízo ou não, e quando estiver na escola, a escola não tem que paparicar, porque se paparicar... 


\section{A história de Rubens - 0 pedreiro sonhador}

[Eu nasci no] Paraná. [Vim pra São Paulo] Com quatro anos, cinco. Vim com a minha mãe, com meu pai, com a minha irmã. Veio junto [morar] com a minha tia no Butantã; num barraco, com três cômodos, não tinha banheiro não. [Morava] Minha mãe, a Elza, a Alice, o Antonio... Mamãe, papai e oito filhos... [Tenho] Três [irmãos], mas morreu um, e seis [irmãs]. Agora são cinco mulheres e dois homens...

[De criança] Eu brincava de carrinho, de fazer feira... Lá no Paraná [eu] não tinha [amigos] não, [brincava] com os irmãos. Estudei [até] seis anos, aqui em São Paulo, no Butantã. Mas, não passei da primeira [série], me mandaram embora ... Gostava [de estudar]... Ouvia um pouquinho... Era boa [a professora], se fosse ruim, não ficava não...

[Depois] Trabalhei de pedreiro, desde uns quatorze anos. Trabalhava com o meu pai, [que também era pedreiro]. [Aprendi] com ele... Eu faço tudo, zelador, pedreiro,... A casa dela [da irmã] fui eu quem fiz... Eu faço tudo melhor... Eu pinto, sou encanador, pedreiro, carpinteiro, fazer telhado... Sozinho... Eu arrumo máquina também, a máquina de lavar roupa... Mas não tem emprego, as firma já não pegam mais... O que me atrapalha é falar. [As pessoas], elas não entendem... Eu falo, mas elas não...

Eu fui [no médico], [mas a irmã tem que ir junto]. Não é ruim... Eu fui [sozinho], [porque] tava ruim o corpo, e fui no médico, [mas demorou para o médico entender]. Não tem emprego, mas tá bom... Ninguém [mais ajuda], só a minha irmã. Meu irmão é meio atrapalhado de cabeça; ele briga e briga e pára... Não dá não...

Moro [sozinho], a empregada vai limpar lá. Eu mesmo faço a comida, muito boa: arroz, feijão, batata, carne... [Me] viro... Eu saio [pra] fazer compra no Extra. Vou sozinho! [Eles] Entendem, pra pagar, eles entendem...

[Eu conserto tudo, e aprendi] Sozinho. [Vou na Santa Ifigênia, buscar material], agora na rua eu não compro não... No camelô, não compro não... A peça não vale nada... Lá na Santa Ifigênia é mais barato.

Eu não crio mais passarinho, [está] tudo doado... Eu criei 200 passarinhos. Eu vendia; gerava passarinhos e eu vendia. [Faz] Quatro anos... Tem [passarinho] ainda, mas vou vender logo. Vou acabar com os passarinhos.

[Eu sou] bravo... Se eu to bravo, eu fico bravo... Eu não gosto quando [me] atentam, as pessoas lá... É ruim... Não entendo... Não gosto que ficam pirraçando. Todo dia eles falam, todo dia eles falam mal de eu falar desse jeito... [Até] No sacolão também, que é pertinho. Vou lá de manhã - de tarde não, só de manhã - porque tem um moleque, um rapaz de vinte e oito, trinta anos [que fica atentando]. [Todos que tem problema de fala] Reclamam... A Marina, minha vizinha, ela não ri... E gente boa, não [fica pirraçando]. [Na rua] tem mulher que pirraça. Mas não posso fazer nada...

É fácil [pegar ônibus]. Pinheiros eu leio. Agora o difícil é o Rosa Maria... O número sessenta e um é Joaquina, agora o dez é Rosa Maria. Já peguei [ônibus errado], tive que descer... Gostaria [de saber ler]. [Depois de adulto, fui para a 
escola] Lá em Bueno Brandão, mas não dei bem com a molecada, [com] os moleques pirracentos lá. Os professores não, eles eram bons... Mas, saí... Bueno Brandão fica perto de Socorro. [Lá] Eu tenho um cunhado e sobrinho; morei lá também uns três anos, depois eu voltei de novo.

[Aqui nas Clínicas, vim atrás] Do ouvido, pra falar direito. Eu já vim [no HC] muitas vezes... Uma vez, [levei] uma pedra aqui [na cabeça]; fui passar lá, levei uma pedra aqui... Seis pontos... Eu tinha quatorze anos. Levei uma pedrada aqui, e quase morri. [Agora, eu tô querendo] Um aparelho, para falar [melhor].

[A televisão é] Bem alta pra eu assistir. Eu gosto do Chaves, Trapalhões... Fita, nós tem filme... Agora vai passar Tarzan, é bom. E rádio, é a música: Roberto Carlos... [E] tem que por bem alto. [Os vizinhos não reclamam], se reclamar, não posso fazer nada...

\section{${ }^{2}$ [Irmã faz um longo relato sobre seu percurso na assistência em saúde, descrito em rodapé].} 2Ele já fez três vezes a audiometria, e experimentou o aparelho... Agora em setembro que chega o
aparelho, depois do dia dez; aí vai marcar uma consulta com o doutor Sérgio, vai passar pela
consulta, ele vai fazer a limpeza do ouvido...
Primeiro foi assim: há um ano e meio que eu passei ele no clínico, porque eu me aposentei há dois
anos, falei: "Vou cuidar, um pouquinho..." Passei na clínica do postinho. Um ano depois eu consegui
passar no otorrino ali no Itaim, o otorrino pediu uma audiometria, fiz lá na Lapa. Voltei no otorrino e
ele deu um encaminhamento para ir marcar a palestra, nós dói fomos na palestra; depois marcou uma
consulta aqui, que passou pelo doutor Sérgio. No mesmo dia já fez uma audiometria, marcaram mais
uma vez, marcaram pra pegar o aparelho e experimentar. Não deu certo! Fizeram os exames e não
estavam batendo os exames. Voltei de novo uns quinze dias depois que ele pegou o aparelho e ficou
com duas semanas com o aparelho, voltei e devolvi o parelho, marquei consulta com o doutor Sérgio.
Aí ele autorizou o encaminhamento para pedir o aparelho... Demora mais ou menos uns três meses. A
Mara lá em baixo, disse que a partir do dia dez de setembro, é pra gente começar a perguntar se
chegou.

[Antes] Ele disse que a mamãe até procurou passar ele no médico. É mais ou menos entre os dez, doze anos, mas não teve resultado. A escola nunca encaminhou, falou que ele não aprendia então, saiu da escola. A mamãe desistiu... Quando ele tinha uns quatorze, quinze anos, passou um homem na rua, vendendo aparelho, a mamãe comprou... Só que ele não conseguia usar, porque doía a cabeça. Também um negócio sem medida... Eu nem sei como que era, porque agora eles fazem o molde... Ele nunca usou, sempre andou jogado este aparelho, nem sei que fim que levou. Mas isso há uns trinta e poucos anos atrás. E foi essa vez que ele tentou usar o aparelho. Depois disso, nunca mais... A gente falava em aparelho e ele não queria saber de nada. Ele não queria saber de aparelho, não queria ouvir falar. Mas eu to achando que ele estava ficando muito mais surdo, muito mais difícil se comunicar... Eu fui nas Clínicas, tem uma médica que é amiga lá do posto, eu pedi pra ela o encaminhamento pro otorrino... Como ele tem muita dificuldade, coitado, ele vende pipa, tem uma lojinha, ele vende pipa, linha de pipa... É um negocinho que ele fez lá na frente da casa dele, porque não consegue trabalho...

Na verdade, eu pedi pra médica, porque eu queria que ela conseguisse o cartão do ônibus pra ele. Porque é tão pouco o que ele ganha pra vender pipa, e ele tem este problema, que pelo menos ele entra no ônibus e não paga a passagem, pra ir comprar as coisas dele, ir no médico... Ela me deu, porque ela viu que realmente ele tem problema, e ela me deu também o encaminhamento pro otorrino. Ela falou: "Mas Elza, pra fazer esse exame, vai demorar muito..." Eu falei: "Só que não tem importância..." Um dia saiu o encaminhamento. Só que, durante esse ano, eu não consegui a passagem de ônibus pra ele, porque eu não tinha o exame novo. Eu só consegui agora, esse ano, a passagem pra ele, e foi bom, porque o que ele tem andado pra baixo e pra cima comigo. Quer dizer, eu pago uma e ele não paga a dele, então já ajuda. E eu também queria aposentar ele, pra conseguir uma renda... Mas eu não consegui, o INSS negou... Disse que não... Como ele trabalhou... Eu trabalhava numa empresa, eu tinha amizade com os engenheiros, com a diretoria, então eu encaixei o outro meu irmão que é deficiente mental, e encaixei ele como pedreiro. Eu ajudei na época, mas agora atrapalhei, porque o INSS falou: "Ele já foi pedreiro, é só ele por um aparelho que ele consegue trabalhar..". 3- Ele explicou pra mim o médico, mas foi de uma grossura tão grande... Eu entrei na sala, dei os papéis, ele foi escrevendo, escrevendo e escrevendo, eu fiquei lá uns quinze minutos em pé e ele escrevendo e escrevendo. Ele imprimiu e falou assim: "Ta pronto! Acabou!" Eu falei: "Acabou como? Você aposentou ele?" Ele falou:"Não, ele não precisa de aposentadoria. Ele já foi pedreiro, ele pode muito bem continuar trabalhando." Eu falei: "Nossa! Mas o senhor não quer olhar nem os exames, as cartas que eu tenho dos médicos?" Ele falou: "Não. Não precisa." Mas foi assim numa 
[Eu tenho problema de coração] Não sei não o que é; tomo [remédio] todo dia. Eu trabalho, eu ajudo ela [a irmã]. Conserto a máquina de lavar roupa, [ajudo a consertar as coisas na casa].

[A carteirinha do ônibus] Tá aqui, é bom! Ela [a irmã] arrumou pra mim. Não faz [tempo] não, faz dois, três meses só. Vale até dois mil e quatorze, dura... E melhorou, ajuda na passagem. Muito barato! [Antes eu ficava mais em casa], e andava mais - mil e quinhentos metros a pé. Andava de bicicleta... [Não é perigoso], faz trinta anos já e não aconteceu nada; eu não ando na rua, eu ando na calçada. Não atrapalha não e nunca bati. [Atravesso a rua] na hora que o farol fecha... Dá [pra ouvir os carros]. [Agora] eu parei um pouco, [só de ônibus]. A perna cansa muito. Fui [no médico]. É dor, não é hérnia, não... É dor aqui, no nervo... Já melhorou um pouco já... Mas dói mais é a coluna aqui... Fazia [serviço pesado], mas parei mesmo...

[A última vez que trabalhei de pedreiro] foi na firma, arrumando telhado. Fernando Lopez Medeiros, esta firma que eu trabalhava. Era lá no Santo Amaro, dois ônibus... [Pras Clínicas, o ônibus] passa na porta. Tem outro também que vai pra Santo Amaro, [e pro] Carrefour.

[Tenho] Cinqüenta e quatro [anos]. [Gosto de passarinho], de mais nada. Gato, não... O cachorro, ele fica mijando lá no portão, enferruja tudo. [Eu gosto de coisas que não são] Velha nada. Essas máquinas que são modernas não prestam mais não. Na rua, eu arrumei uma mesa, uma mesa boa. [Um aspirador], tá cheio de peça, prestando... O aspirador, ele ta bom, mas só o motor ta ruim... É só o motor; se arrumar o motor fica bom. Se tivesse ruim, eu não pegava não... [E a mesa] Não é pesada não, ela dobra, vira... Ta boa ainda, não ta ruim. Se tivesse ruim, eu não pegava... A máquina de lavar [eu comprei], mas é das antigas; as modernas é só plástico. Uma vez já quebrou a máquina [moderna] dela [irmã], eu arrumo, mas não é igual.

(...) [Nunca namorei], sei lá... Nunca quis... [Tenho vergonha do problema da fala]. [Elas] não [gostam], não tem [mulher que goste].

[Sou] Mais ou menos [bonzinho]. Às vezes a gente fica bravo . [Por exemplo] Com a cachorra, [que] suja tudo. Eu jogo a areia lá, mas tá prenha, suja tudo. [É a cachorra da minha irmã]. [Ela pulou o portão, arrebentou as mangueiras da máquina], mas agora não fura mais. Eu coloquei um ferro, aí não fura mais, nem não pula mais não... Sabe o que [cachorro] não gosta? Foguete, muito barulho... E com a Copa do Mundo vai estourar mais... Vou [assistir a Copa], a gente tem que torcer, mas ganhar não vai. Tá muito perigoso [o futebol], [nunca fui] no campo não, só na televisão; é muito perigoso pra ir lá, não vou não. É muito perigoso, pode matar gente...

Eu já fui na Lapa [também]. Machuquei a perna direita, fui na Lapa na época que caiu. Eu fui lá e cuidaram, no hospital. [Hospital] Matarazzo, já fechou. [Hoje está tudo] diferente, [foi em] setenta e oito. [Faz tempo...] Machucou a perna esquerda, bateu assim, aqui... Doía muito...

grossura tão grande. Porque por que ele nunca mais arrumou emprego? Porque ele tem um problema de arritmia, e toda vez que ele ia arrumar emprego, não passava no exame admissional, por causa da arritmia... E mesmo ele tomando o remédio, não passa, tem arritmia direto... Então ninguém pega ele mais, pra fazer serviço pesado... 
[Eu comecei a trabalhar] com quatorze anos. Eu, Antonio e papai; os três juntos. É verdade... [Trabalhei] Fazendo casa, eu, meu pai, meu irmão... Eu tinha quatorze anos. [Meu primeiro emprego foi] no japonês marceneiro. Eu fazia parede, em casas grandes, bem alto... Depois eu tava trabalhando com meu pai, indo, indo, indo... daí meu pai parou. Eu fui pra firma... Setenta e quatro... O meu irmão arrumou lá... Ele morreu já... Ele trabalhou de guarda e eu era de ajudante. Eu não fazia nada, só ajudante... Depois, com o tempo, não queria ficar lá não... Muito pesado... Daí saí, arrumei [de] pedreiro... [Depois] fiquei parado; uns três meses fiquei parado... [Hoje em dia] eu não tô [trabalhando], só na loja. É [bom, mas] fica parado...

La na empresa [era] fazendo cano de esgoto... [E cano de] esgoto não é fininho não, é grande... É um e vinte... E não era só eu não... [Eu] gostava... [O que mais gostei foi de] Pedreiro, qualquer um... Fazer parede de tijolo, massa fina... [Piso] Eu ponho, mas a perna não agüenta mais. Esta aqui está boa, [mas] esta aqui não. Se eu abaixar assim, dói; o sangue prende. Não dá pra fazer... Eu tento levantar, mas não levanta mais. E eu fazia assim... Dói, mas pra andar não dói não, só abaixar... Que vergonha [com] a Marina: eu fui fazer o piso lá, não agüentei mais...

Gosto [de ir no médico]. Já operei a hérnia, também. Eu vou com ela [irmã]. Foi em noventa e três; ficou [bom depois].Depois tirou aqui, não era hérnia não... Doía, mas agora melhorou um pouco, eu tomei remédio. [Era] o nervo; dói, mas agora melhorou... [Agora tem um carocinho] aqui [no braço], furúnculo. [Tive] foi seis furúnculos; foi nas Clínicas [que tratei]. Resolveu... Vou [usar o aparelho]. [Já] Usei, mas não deu certo; me doeu a cabeça. [Quando estou doente, vou] no posto de saúde e no pronto socorro também... [Sempre] Acompanhado...

[Os médicos] às vezes entendem [o que falo], às vezes não... [Preciso do] aparelho... Não dá não, [pra ficar sem]. Não dá mais... O Caio [cunhado] entendeu quando ele me ouviu falar de aparelho. Ele entendeu lá na cozinha. Eu falei, ele entendeu. [Eu tava] de aparelho... Agora não entendo, [quando colocar] o aparelho, vou entender... Vai melhorar... O João Vitor [sobrinho] fala baixinho; baixinho eu não escuto... Tem um menino que vinha comprar pipa, linha, que ele fala baixinho... É só um, ele fala baixinho; falo: "Fala mais alto!", [ele] não fala... "Fala mais alto, que ninguém escuta!"... Mulher tem umas que falam mais alto, outras falam mais baixo, algumas entendo... É ruim! É ruim [com muita gente], [com] pouca gente [é melhor]... Nem o Zé barbeiro não [me] entende... A Marina entende, não sei por quê...

Não [gosto de] festa. Eu gosto de dormir... Eu assisto à televisão, só... [Se] Reunir [a família, só venho pra comer]... [Minha irmã] chama eu, [mas só venho] pra comer... Sei lá!

E nunca mais eu como frango, porque o meu pai brigou comigo. Era frango de panela e ele gostava de couro de galinha. E ele mandava eu comer... Não como mais, desde os quinze anos. [Eu gosto de] carne, verduras, brócolis, couve flor... Mas [alface] não dá pra comer, porque dá sono. Agora escarola eu como, tomate... [Eu] Faço [a comida]; [cozinho] mais ou menos. Nem o cachorro num come... Não sobra pra eles...

(...) [Moro sozinho porque] Eu e meu irmão ficamos brigando, não dá certo. Eu e ele uma vez já brigou, mas parou. Foi em dois mil e dois [que passei a morar sozinho], oito anos... Ele brigou comigo, não sei porque. Não gosta de mim, o 
meu irmão! [Sou mais bagunceiro], é verdade... Às vezes lavo [a louça], mas eu lavo... Às vezes não tenho tempo, tenho que ficar lá na loja... Gosto [da empregada], mas... [Minha irmã] arrumou uma empregada que roubou [meu] dinheiro; ela abriu o guarda roupa, tinha um buraco, ela abriu, pegou a chave... Ela foi embora já... Essa [que está agora] é normal... Vai sempre [só uma vez por mês].

Era pouquinho [dinheiro], não muito... Não era muito dinheiro, [mas era meu]... Era pouco, era pra fazer compra, e ela roubou o dinheiro. Lá em casa tem um cofre, ninguém sabe... Na tomada... Ninguém sabe, e [não] vão abrir... Não dá choque... O [meu] medo de ladrão é [de] roubar dinheiro... [Só teve] a empregada, foi só essa vez...

[Eu pus câmera] na lojinha. E [alguém me] passou dinheiro falso. Eu não sabia que era falso. Eu não sabia... Muito falso... Eu vou comprar a lâmpada azul, e vou estender assim, se é falso... Vou comprar, não tenho ainda... Fui [eu quem pus a câmera na loja], [comprei] na Santa Ifigênia. Lá, na loja é muito barato; aqui é caro, tem de mil reais. Na Santa Ifigênia não, é cinqüenta... [Não é muito cheio] Cheio é na Vinte e Cinco de Março; já [fui lá] comprar. [Muita gente] Não [atrapalha o ouvido], é normal...

Eu vou sozinho. Eu mesmo vou procurar... Não [fico perguntando], eu vou escolher. [O vendedor] não fala nada, [vou] por minha conta. [Se não], fica difícil... Eu não compro na rua, no camelô. Porque não tem nota, não tem nada, [não tem] garantia. Uma vez comprei, o cara não deu garantia, não deu nota. Nunca mais eu compro. Nem as roupas eu não compro no camelô; era em Pinheiros, agora não tem mais. Acabou. Tão reformando tudo! Mesmo assim, não compro mais; [eu compro] no Brás e na Vinte e Cinco.

Já foi em Atibaia? Eu trabalhei lá, fiquei três meses... De pedreiro... Faz tempo já; foi em setenta e oito. Atibaia, Cacatuba ${ }^{3} . .$. Faz tempo... Três meses trabalhei pra fazer colégio de escola. Mas não é sozinho não, pra firma mesmo... A gente ficava quinze dias, depois voltava. Depois... Segunda feira voltava de novo. A firma pagava a passagem.

(...) Eu tomo café direto. Só o frango eu não como, meu pai brigou comigo, nunca mais. Ele morreu, faz tempo... Ele morreu em noventa e três. Ele era ruim, [eu] apanhava com a cinta. [Era] bravo... Depois de grande, eu não apanhava mais... [Quando] eu era menor - quatorze anos, treze - [ele] também brigava. Também brigava [com meus irmãos, minha mãe]. Lá na Bahia, ela apanhou... É verdade! Ele bebia pinga e meu pai ó... Não foi aqui, foi na Bahia. [Eu] era [bonzinho], ele era bravo. Depois de grande, eu não apanhei mais. [Meus pais nasceram na] Bahia, não sei [a cidade]. Serra de Brumado... Bem longe! Pra lá da Bahia. Eu tenho meu tio lá, também. Tem primo... Eu já fui uma vez lá e não fui mais; foi em mil novecentos e oitenta e quatro, depois eu não fui mais. Eu não sei ir mais lá!

Eu sei ir em Minas Gerais, [onde moram] meu cunhado e meu sobrinho. Vou [sozinho]. Duas horas [de viagem], de carro. De ônibus, você pega de manhã, as dez da manhã, chega lá uma e meia. Bueno Brandão... Morei lá, [mas] não dava emprego, fui embora. São Paulo [é mais fácil], [mas] é difícil... Queria [trabalhar de] pedreiro... Mas outra coisa, arrumar máquina, pintar, mais leve... Trabalhar por firma... (...) [Com o aparelho vai ficar mais fácil].

${ }^{3}$ Caraguatatuba 
Eu tenho uma filmadora, [gosto de filmar]. Eu filmo a Marina, a sobrinha dela. É fácil [de mexer]. Eu comprei na Vinte e Cinco de Março, naquele prédio lá do lado. Na Pojá ${ }^{4}$; sai mais barato. Lá na loja é mil e duzentos; eu paguei seiscentos. A metade do preço... Uso pouco... Tem uns dois anos e pouco [que comprei]. Agora não tem [mais] a fita, agora é DVD. É moderno... Não vende [mais a fita]. Mas o relógio lá [na Galeria Pajé], não presta... Comprei um relógio, mas já estragou. Não compro mais, é porcaria. [A câmera] não deu problema não, mas é preto e branco... A boa é a colorida...

Eu não tenho coisa pra falar... [Quando] Criança, eu morava no barraco lá, eu gostava de pipa. Tinha sete [anos], oito, nove... Eu fazia [a pipa], mas não subia, ficava torto. Eu não [sabia] fazer pipa naquela época, agora eu sei fazer... Era peixinho... Eu tinha [amigos], mas não dava não... Era ruim, onde eu morava não dava não. [Eles faziam] ruindade...

Depois mudei pra cá, eu tinha dez anos. [Morava] minha mãe, meu pai, minha irmã... Alice, Elza, eu, Tonho, Zenaide e Zeli... Seis mulheres... Agora morreu um, faz tempo... [Ele morreu] do bicho barbeiro, lá no Paraná. Passou vinte anos, [doente do] coração. Nunca vi o barbeiro... Morreu faz trinta anos, tem quatro filhos...

[Aqui em São Paulo, eu brincava de] Pipa de novo. Não [jogava bola], só pipa. Não [tinha televisão], não tinha luz. Não tinha asfalto, não tinha nada. Não tinha água da rua... [Colocou] água da rua [em] setenta e sete. O asfalto não, primeiro foi o asfalto. [O bairro] era do tamanho que é [hoje], o que começou a ter é favela, lá pra cima. [Antigamente] não tinha. Começou em oitenta. É perto aqui, ali é a favela. [O pessoal é] bacana, conheço [os vizinhos].

[Fui na escola com] Seis anos. Era longe daqui. [Ia] de ônibus, é longe... Três quilômetros, no quilômetro dez. Tem ainda [a escola], é [antiga]. Eu tava aprendendo a ler, [mas] eu não sei fazer... A professora fala, você escreve... Eu não sei fazer a mesma coisa que ela faz... Nem uma conta eu não sei fazer... Eu não fazia... Eu sei fazer na calculadora, na cabeça eu não sei fazer. Tinha [muita gente na classe], [a professora] ensinava, não sei [porque não aprendi]. Eu ouvia... Eu não sei o que a professora fala e tem que escrever... Me mandaram embora. Eu fui lá, ele me deu um papel e eu não fui mais. Não sei [se gostaria de voltar a estudar].

Eu não sei [do futuro]. [Quero voltar a trabalhar] de pedreiro, mas não tem... Ah, e ganhar [na mega sena]. Eu jogo um pouquinho, mas não acerto. Eu já acertei a quadra, outro dia. [Dá um] pouquinho [de dinheiro], às vezes, depende... [se tem] muita gente, pouca gente... Se tiver muita gente, dá noventa; já pouca gente, dá seiscentos... [Ganhei] a primeira vez cento e vinte cinzo. Eu ganhei a segunda duzentos... Depende... E tá acumulada agora, a Mega Sena. [Eu aposto] dois reais, mas demora [pra ganhar algum dinheiro]. Se você jogar muito, perde, o dinheiro vai embora... [Eu aposto] na lotérica, aqui perto. Mas, eu não gosto de jogar baralho... Baralho não é bom não, eu não gosto, perde dinheiro. Nem palito, nem nada... Eu só jogo na mega sena, e na quina. Eu mudo [os números que jogo]; tem que mudar, se não... Vou tentando... Seis números... Agora a quina, é cinco; a quina é mais barato. Se pôr seis [números], é dois reais; se pôr cinco [números], é cinqüenta centavos. Olha a diferença... Mas mesmo assim é difícil; a quina tem oitenta números, a

${ }^{4}$ Galeria Pajé / SP 
mega sena tem sessenta. (...) [Jogo] duas vezes por semana. (...) [Dinheiro] é bom...

[A loja não] tá vendendo nada, é muito devagar. Vendeu ontem, água. E vende linha, pipa... Agora não é época não, é outro mês, [de férias] da escola. Tem [criança aqui], mas os outros já cresceram, não compram mais. [Compra com] nove anos, oito anos; [com a criançada] mais velha é bola...

[Mas] Na rua não jogam não, é muito perigoso aqui. [É muito movimento aqui desde] quando começou a fazer o asfalto... Caminhão, carreta, trator... Tinha isso tudo aqui... A casa em cima racha tudo... Não atrapalha, mas racha... E tem água [lá na rua], o poço de um metro.... Mas não presta mais não, tá contaminada, por causa do esgoto. De primeira era boa, mas agora... (...) Esse terreno aqui era vazio, e plantava cana. Era da minha mãe [o terreno]. Eu chupei cana, agora não tem mais. Não dava pra criar vaca aqui não... Cachorro eu criava, mas faz muita sujeira... É bom criar na roça...

[Morei] Em Minas Gerais, [em] Bueno Brandão. Eu plantava lá... Arroz, plantava milho, essas coisas... Era minha. Não [vendia], [era] pra comer... Plantava arroz, milho pra galinha. Fazia pamonha... A minha mãe, meu pai, moravam lá... Eu, meu irmão, minha mãe... E tem a menina, a Edna, que foi pra Bahia.... A Edna não prestava não, mexia em tudo... [Fiquei lá] três anos...Oitenta e quatro, oitenta e cinco, e oitenta e seis. [Depois] Não tinha roça. Acabou. Não tinha sítio, [voltei...] Plantava verdura no terreno, alface, cebolinha, couve... Não [vendia], comia. [Meu pai] trabalhava [na roça] e [serviço de pedreiro também] tinha. Eu fazia, [mas] eu não achei nenhum emprego. Eu fiquei lá, procurando emprego e não achei. Voltei, vim trabalhar aqui [como] pedreiro, agora eu parei...

(...) [Eu compro comida] no Extra, no Makro... Dá mil e quinhentos metros, na Raposo... O Makro aí é longe daqui... Vou sozinho, compro arroz feijão... As vezes compro macarrão. A carne eu não compro lá não. [É] Muito caro! [Compro no] Makro, uma peça inteira. Primeiro eu faço bife, coloco na geladeira... Preço eu sei [eu consigo compreender], mas eu não sei ler [o nome dos produtos]. Agora eu não fui mais lá; não tenho dinheiro pra gastar lá... Eu também não gosto de crédito, [cartão de crédito], depois pra pagar não tem dinheiro...

Faço [tudo, as compras, a comida...] Aprendi com a minha mãe, eu via [ela] fazendo... [O que mais gosto] é fazer comida, arroz, feijão, carne, verdura... [Peixe] eu como, gosto... Gosto de [doce] de amendoim, bóbora... Café... De noite eu assisto o Ratinho... O [cidade] Alerta, no [canal] sete... [Vou dormir] dez horas, levanto sete horas, sete e meia... Eu lavo [a roupa] na máquina, minha máquina antiga... Não passo [roupa] não, [assim] não gasta luz. Todo mundo paga a luz, [os irmãos juntos]... (...) E hoje de manhã [minha irmã] brigou comigo. [Quando é assim, eu] fico escutando... Acontece sempre...

[Se] Eu ganhar na Mega Sena eu vou mudar, vou embora daqui... Vou comprar um terreno, vou comprar um sítio e virar fazendeiro... [Vai ter] vaca, vai ter manga, mexerica, laranja...

Eu já trabalhei já [na roça]. Agora batatinha não dá lucro, gasta muito dinheiro. Se você gasta quarenta mil de planta, você perde metade... Não dá lucro. Café dá... E outro, a batatinha, o gelo mata. Mandioca dá dinheiro...Batata doce... Milho... (...) Mas não pode plantar [em terra forte] forte, tem que ser terra 
fraca... Arroz também, não pode ser forte não. Tem que ser fraca também... [Terra forte é pra] batatinha, feijão... Eu sei de tudo...

Eu ia procurar [um lugar pra minha fazenda]. Longe, perto daqui é muito perigoso... Minas, não sei... Bahia, eu já fui lá uma vez... Eu nasci no Paraná, [mas fui na Bahia] passear... A gente ficou trinta dias... Tinha prima lá também, tinha primo também... [Cidade] pequena, tudo plano.... Muito calor... De calor, [eu] não gosto não... Nem o frio nem o calor... Médio...

Gosto de tomar banho na piscina... [Fui na praia] faz muito [tempo]... Queima muito, o sol... Piscina é melhor pra tomar banho...E me queimou muito aqui, não [passei] bronzeador... Quase morri! Uma vez que eu fui, muita gente foi pra praia; foi e voltou... Cheguei aqui, não encostava desse lado. Eu não fui nem trabalhar, todo queimado... Passei creme... tava assim, ardendo... Agora não fui mais... Faz vinte anos que não fui mais... Tenho vontade, mas fazer o que, não tem carro, não tem nada...

[Final de semana eu fico em casa] Vendo a água, e no sábado vou fazer jogo.... e na quarta feira... Amanhã vou fazer jogo... [Mas] Não deu nada,nenhum ponto...(...) Tele Sena [eu] joguei já; faz dezoito anos, eu não ganhei nada. Eu parei... Eu tenho tele sena, eu vou trocar pra dar dinheiro... É pouco, duas tele sena, dá cinco reais... Eu parei de jogar, nunca deu... Dezoito anos! Desde o começo, [em] noventa e um. Eu parei já... Passa [o tempo] e ninguém acerta... Eu não conheço [ninguém que ganhou]. Não sei [se é verdade].

Agora a Mega Sena é verdade... 


\section{Referências Bibliográficas}

1. Rocha,EF. Deficiência e reabilitação: questões históricas e epistemológicas. In: Rocha, EF. (org) Reabilitação de Pessoas com Deficiência. A Intervenção em Discussão. São Paulo: Roca, 2006. p.09-60.

2. Almeida,MC; Tissi,MC; Oliver,FC. Deficiência e atenção primária em saúde: do conhecimento à invenção. Rev. Ter. Ocup. Univ. São Paulo, v.11, n.1, p.33-42, jan./abr. 2000.

3. Bernardes, LCG; Maior, IMML; Spezia, CH; Araújo, TCCF. Pessoas com deficiência e políticas de saúde no Brasil: Reflexões Bioéticas. Ciencia e Saúde Coletiva, 14(1): 31-38, 2009.

4. Brasil. Ministério da Saúde. Secretaria de Assistência à Saúde. Coordenação de Atenção a Grupos Especiais. Programa de Atenção à Saúde da Pessoa Portadora de Deficiência. Atenção à Pessoa Portadora de Deficiência no Sistema Único de Saúde: planejamento e organização de serviços, Brasília, DF, 1993. 48p.

5. Instituto Brasileiro de Geografia e Estatística. Censo Demográfico 2000. Características Gerais da População. Rio de Janeiro: IBGE, 2003. 178p.

6. Prefeitura de São Paulo. Aspectos Demográficos. Disponível em: <http://portal.prefeitura.sp.gov.br/subprefeituras/spbt/dados/0001/portal/ subprefeituras/spbt/dados/aspectos_demograficos/0001>. Acesso em: 24 ago. 2008.

7. Coordenadoria Nacional para Integração da Pessoa Portadora de Deficiência. Relatório sobre a prevalência de deficiências, incapacidades e desvantagens. Rio de Janeiro: CORDE, Ministério da Justiça, 2004. 53p. 
8. Brasil. Portaria MS/GM n.1060/2002. Dispõe sobra a criação da Política Nacional de Saúde da Pessoa com Deficiência. Brasil, 2002.

9. Pereira,R. Anatomia da Diferença. Normalidade, deficiência e outras invenções. São Paulo: Casa do Psicólogo, 2008. 170p.

10. Caiado,KRM. Aluno deficiente visual na escola. Lembranças e depoimentos. 2a.ed. Campinas, SP: Autores Associados / PUC, 2006. 151p.

11. Pan,JRA. Afetividade e sexualidade na pessoa portadora de deficiência mental. Trad.: Maria Stela Gonçalves. São Paulo: Edições Loyola, 2003. $446 p$.

12. Ghirardi,MIG. Representações da deficiência e práticas de reabilitação: uma análise do discurso técnico. 1999. 150p. Tese (Doutorado em Psicologia) Universidade de São Paulo, São Paulo, 1999.

13. Palacios,A.; Romañach,J. El modelo de la diversidad. La bioética y los derechos humanos como herramientas para alcanzar la plena dignidad em la diversidad funcional. España: Ediciones Diversitas, 2006. 248p.

14. Amiralian,MLT; Pinto,EB; Ghirardi,MIG; Lichtig,I; Masini,EFS; Pasqualin,L. Conceituando deficiência. Revista de Saúde Pública, São Paulo, v.34, n.1, fev. 2000. p.97-103.

15. Diniz,D. O que é deficiência. São Paulo: Brasiliense, 2007. Coleção Primeiros Passos. 89p.

16. Farias,N; Buchalla,CM. A classificação internacional de funcionalidade, incapacidade e saúde da organização mundial da saúde: conceitos, usos e perspectivas. Rev. bras. epidemiol., v.8 n.2 São Paulo jun. 2005. 
17. Ribas,J. Preconceito contra as pessoas com deficiência. As relações que travamos com o mundo. São Paulo: Editora Cortez, 2007. Coleção Preconceitos. 120p.

18. Sassaki,RK. Como chamas as pessoas que têm deficiência? São Paulo, janeiro de 2005. Disponível em: <http:www.cnbb.org.br/documento_geral/ RomeuSassakiComochamaraspessoas.doc>. Acessado em: 15 abr. 2008.

19. Pereira, R. Diversidade funcional: a diferença e o histórico modelo de homem-padrão. História, Ciências, Saúde - Manguinhos. Rio de Janeiro: v.16, n.3, jul.-set. 2009, p.715-728.

20. Nemes Filho,A. A unidade básica e o sistema de saúde. In: Schraiber,LB; Nemes,MIB; Mendes-Gonçalves,RB. (orgs) Saúde do adulto: programas e ações na unidade básica. $2^{\circ}$ ed. São Paulo: Hucitec, 2000. p.276-286.

21. Cecilio, LCO. As necessidades de saúde como conceito estruturante na luta pela integralidade e equidade na atenção em saúde. In: Pinheiro,R.; Mattos, RA. (orgs) Os sentidos da integralidade na atenção e no cuidado à saúde. $6^{a}$ ed. Rio de Janeiro: UERJ, IMS:ABRASCO, 2006. p.115-128.

22. Almeida, MC; Campos, GWS. Políticas e modelos assistenciais em saúde e reabilitação de pessoas portadoras de deficiência no Brasil: Análise de proposições desenvolvidas nas últimas duas décadas. Rev. Ter. Ocup. Univ. São Paulo, v.13, n.3, p.118-26, set./dez. 2002.

23. Quintão, DTR. Algumas reflexões sobre a pessoa portadora de deficiência e sua relação com o social. Psicologia \& Sociedade; 17(1): 17-28; jan./abr. 2005.

24. Brasil. Ministério da Saúde. Secretaria de Assistência à Saúde. Manual de Legislação em Saúde da Pessoa Portadora de Deficiência. Brasília: Ministério da Saúde, 2006. 346p. 
25. Brasil. Portaria no 154, de 24 de janeiro de 2008. Cria os Núcleos de Apoio à Saúde da Família - NASF. Brasil, 2008.

26. Holanda, AB Mini dicionário: O dicionário da Língua Portuguesa. 6a.ed. São Paulo: Editora Positivo, 2004. 896p.

27. Campos,CMS; Bataiero,MO. Necessidades de saúde: uma análise da produção cientifica brasileira de 1990 a 2004. Interface-Comunic., Saúde, Educ., v.11,n.23, p.605-618,set/dez. 2007.

28. Mendes-Gonçalves,RB. Práticas de saúde: processos de trabalho e necessidades. São Paulo: CEFOR, 1992. 53p.

29. Campos, CMS; Mishima, SM. Necessidades de saúde pela voz da sociedade civil e do Estado. Cad. Saúde Pública, Rio de Janeiro, 21(4): 1260-1268, jul-ago, 2005.

30. Morais, TCP. Necessidades em saúde e trabalho das equipes de saúde da família: a dialética do reconhecimento e enfrentamento. [Dissertação de Mestrado]. São Paulo, Escola de Enfermagem da USP, 2008. 113p.

31. Schraiber,LB; Mendes-Gonçalves,RB. Necessidades de saúde e atenção primária. In: Schraiber,LB; Nemes,MIB; Mendes-Gonçalves,RB. (orgs) Saúde do adulto: programas e ações na unidade básica. $2^{\circ}$ ed. São Paulo: Hucitec, 2000. p.29-47.

32. Silva, JPV; Pinheiro,R; Machado, FRS. Necessidades, demanda e oferta: algumas contribuições sobre os sentidos, significados e valores na construção da integralidade na reforma do Setor Saúde. Saúde em Debate, Rio de Janeiro, v.27, n.65, p.234-242, set./dez., 2003.

33. Merhy, EE. Modelo de Atenção à Saúde Como Contrato Social. Texto Apresentado na 11a. Conferencia Nacional de Saúde. Brasília, 2000. (mimeo). 
34. Oliver,FC; Almeida,MC; Tissi,MC; Castro,LH; Formagio,S. Reabilitação Baseada na Comunidade: discutindo estratégias de ação no contexto sociocultural. Rev. Ter. Ocup. Univ. São Paulo, v.10, n.1, p.1-10, jan./abr. 1999.

35. Oliver,FC; Tissi,MC; Aoki,M; Vargem,EF; Ferreira,TG. Participação e exercício de direitos de pessoas com deficiência: análise de um grupo de convivência em uma experiência comunitária. Interface - Comunicação, Saúde, Educação, v.8, n.15, p.275-88, mar./ago. 2004.

36. Saraceno,B. Reabilitação psicossocial: Uma estratégia para a passagem do milênio. In: Pitta,A. (org.) Reabilitação psicossocial no Brasil. São Paulo: Hucitec, 1996. p.13-18.

37. Rocha,EF. Queixas dos usuários do ambulatório do REATA: uma releitura. In: Rocha,EF. (org) Reabilitação de Pessoas com Deficiência. A Intervenção em Discussão. São Paulo: Roca, 2006. 136-143p.

38. Santos,EM; Shiratori,K. As necessidades de saúde no mundo do silêncio: um diálogo com os surdos. Revista Eletrônica de Enfermagem, v.06, n.01, p.68-76, 2004.

39. Mattos,RA. Os sentidos da integralidade: algumas reflexões acerca de valores que merecem ser definidos. IN: Pinheiro,R; Mattos,RA. (org.) Os sentidos da integralidade na atenção e no cuidado em saúde. 6a ed. Rio de Janeiro: UERJ, IMS: ABRASCO. 2006. 41-66p.

40. Lacerda,A; Valla, VV. As práticas terapêuticas de cuidado integral à saúde como proposta para aliviar o sofrimento. In: Pinheiro,R; Mattos,RA (orgs.) Cuidado. As fronteiras da integralidade. $3^{a}$ ed. Rio de Janeiro: CEPESC/UERJ, ABRASCO, 2006. p.91-102. 
41. Ayres,JRCM. O cuidado, os modos de ser (do) humano e as práticas de saúde. Saúde e Sociedade, v.13, n.3, p.16-29, set-dez/2004.

42. Mattos,RA. A integralidade na prática (ou sobre a prática da integralidade). Cad. Saúde Pública, 20(5): 1411-1416, 2004.

43. Mota,TD. As necessidades de saúde na perspectiva dos usuários de um serviço comunitário de saúde mental. [Dissertação de Mestrado]. São Paulo: Escola de Enfermagem da Universidade de São Paulo, 2007. 117p.

44. Minayo,MCS. O Desafio do Conhecimento. Pesquisa Qualitativa em Saúde. 10ª ed. São Paulo: Hucitec, 2007. 406p.

45. Rocha,EF; Brunello,MIB. Avaliação Qualitativa em Terapia Ocupacional: Princípios, Métodos e Técnicas de Coleta de Dados. In: Cavalcanti, $A$; Galvão, C. Terapia Ocupacional. Fundamentação e Prática. Rio de Janeiro: Guanabara Koogan, 2007. p.44-48.

46. Bosi, E. Memória e Sociedade. Lembrança de velhos. 13a ed. São Paulo: Cia das Letras, 2006. 484p.

47. Queiroz, MIP. Relatos orais: do "indizível" ao "dizível". Ciência e cultura; 39(3): 272-286. mar. 1987.

48. Schraiber,LB. Pesquisa qualitativa em saúde: reflexões metodológicas do relato oral e produção de narrativas em estudo sobre a profissão médica. Rev. Saúde Pública, 29(1): 63-74, 1995.

49. Gonçalves,RC; Lisboa, TK. Sobre o método da história oral em sua modalidade trajetórias de vida. Rev. Katál. Florianópolis, v.10, n.esp.. p.83-92, 2007. 
50. Camargo, A. Os usos da história oral e da história de vida: trabalhando com elites políticas. Dados - Revista de Ciências Sociais, v.27, n.1, 1984. p.528

51. Houltz, A. Versiones biográficas / versiones autobiograficas. Las entrevistas y el material autobiografico como medio de comunicación y método para recabar información. Historia, Antropologia y Fuentes Orales, v.2, n.18, 1997. p.63-72.

52. Flick, U. Uma introdução à pesquisa qualitativa. Trad. Sandra Netz. 2.ed. Porto Alegre: Bookman, 2004. 312p.

53. Baena,VC; Borrego,IG. La transcripción en historia oral: para un modelo "vivo" del paso de lo oral a lo esrito. Historia, Antropologia y Fuentes Orales, v.2, n.18, 1997. p.41-62.

54. Wash,CL. Enfrentando a deficiência. A manifestação, a psicologia, a reabilitação. São Paulo: EDUSP, 1988. 283p.

55. Goffmann,E. Estigma: Notas sobre a Manipulação da Identidade Deteriorada. Tradução de Márcia Bandeira de Mello Leite Nunes. $4^{a}$ ed. Rio de Janeiro: LTC, 1988. 158p.

56. Sacks,O. Um Antropólogo em Marte. Sete Histórias Paradoxais. Trad.: Bernardo Carvalho. 5a. reimp. São Paulo: Cia das Letras, 2000. 331p.

57. Silva,RG. Gênero, Cuidado e Deficiência: um estudo no Ministério Público do Distrito Federal e Territórios. [Monografia de Conclusão de Curso]. Departamento de Serviço Social da Universidade de Brasília. Brasília, 2008. $58 p$.

58. Othero,MB; Dalmaso,ASW. Pessoas com deficiência na atenção primária: discurso e prática de profissionais em um centro de saúde-escola. Interface - Comunicação, Saúde, Educação, vol.13, no.28, p.177-188, mar. 2009. 
59. Brasil. Lei n. 8213/91. Dispões sobre as cotas para Pessoas com Deficiência. Brasil, 1991.

60. Instituto Nacional de Seguridade Social. Benefício de Prestação Continuada da Assistência Social. BPC-LOAS ao idoso e à pessoa com deficiência. Disponível em: < http://www.previdenciasocial.gov.br/conteudoDinamico.php?id=23> Acesso em 27.07.2010.

61. São Paulo Transportes S.A. (SPTRANS). Serviço de Atendimento Especial. ATENDE. Disponível em: < http://www.sptrans.com.br/passageiros especiais

Latende.aspx> Acesso em: 26.07.2010.

62. Lacerda,A; Valla,V. Homeopatia e Apoio Social: Repensando as práticas de integralidade na atenção e no cuidado à saúde. In: Pinheiro,R; Mattos,RA. Construção da integralidade: cotidiano, saberes e práticas em saúde. $4^{a}$ ed. Rio de Janeiro: UERJ, IMS: ABRASCO, 2007. p.91-102.

63. Santos,WR. Pessoas com deficiência: nossa maior minoria. Physis Revista de Saúde Coletiva, Rio de Janeiro, 18(3): 501-509, 2008.

64. Silva Junior,AG; Merhy,EE; Carvalho,LC. Refletindo sobre o ato de cuidar da saúde. In: Pinheiro,R; Mattos,RA. Construção da integralidade: cotidiano, saberes e práticas em saúde. $4^{a}$ ed. Rio de Janeiro: UERJ, IMS: ABRASCO, 2007. P.115-130.

65. Ayres,JRCM. Sujeito, intersubjetividade e práticas de saúde. Ciência e Saúde Coletiva, v.6, n.1, p.63-72, 2001.

66. Schisler,ED. O conceito de dor total no câncer. In: Nascimento-Schulze,CM. (org.) Dimensões da dor no câncer. Reflexões sobre o cuidado 
interdisciplinar e um novo paradigma da saúde. São Paulo: Robe Editorial, 1997. p.49-62.

67. Ayres, JRCM.; Junior,IF; Calazans,GJ; Filho,HCS. O Conceito de Vulnerabilidade e as Práticas de Saúde. In: Czeresnia,D.; Freitas,CM. (orgs.) Promoção da Saúde - Conceitos, Reflexões e Tendências. Rio de Janeiro: Fiocruz, 2003. p.117-139.

68. Ferrari, MAC. Lazer e ocupação do tempo livre na terceira idade. In: Neto, MP (org.) Gerontologia. A velhice e o envelhecimento em visão globalizada. São Paulo: Atheneu, 2005, p.98-105.

69. Gadamer,HG. Verdade e Método. Trad. Flávio Paulo Meurer. 9a.ed. Petrópolis, RJ: Vozes. Bragança Paulista, SP: Editora Universitária São Francisco, 2008. 631p. 